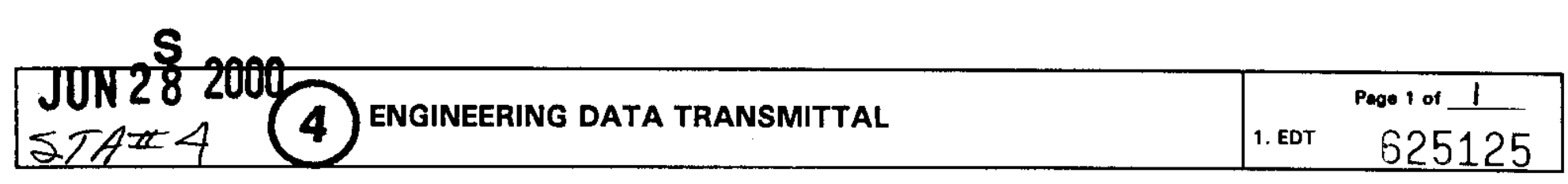

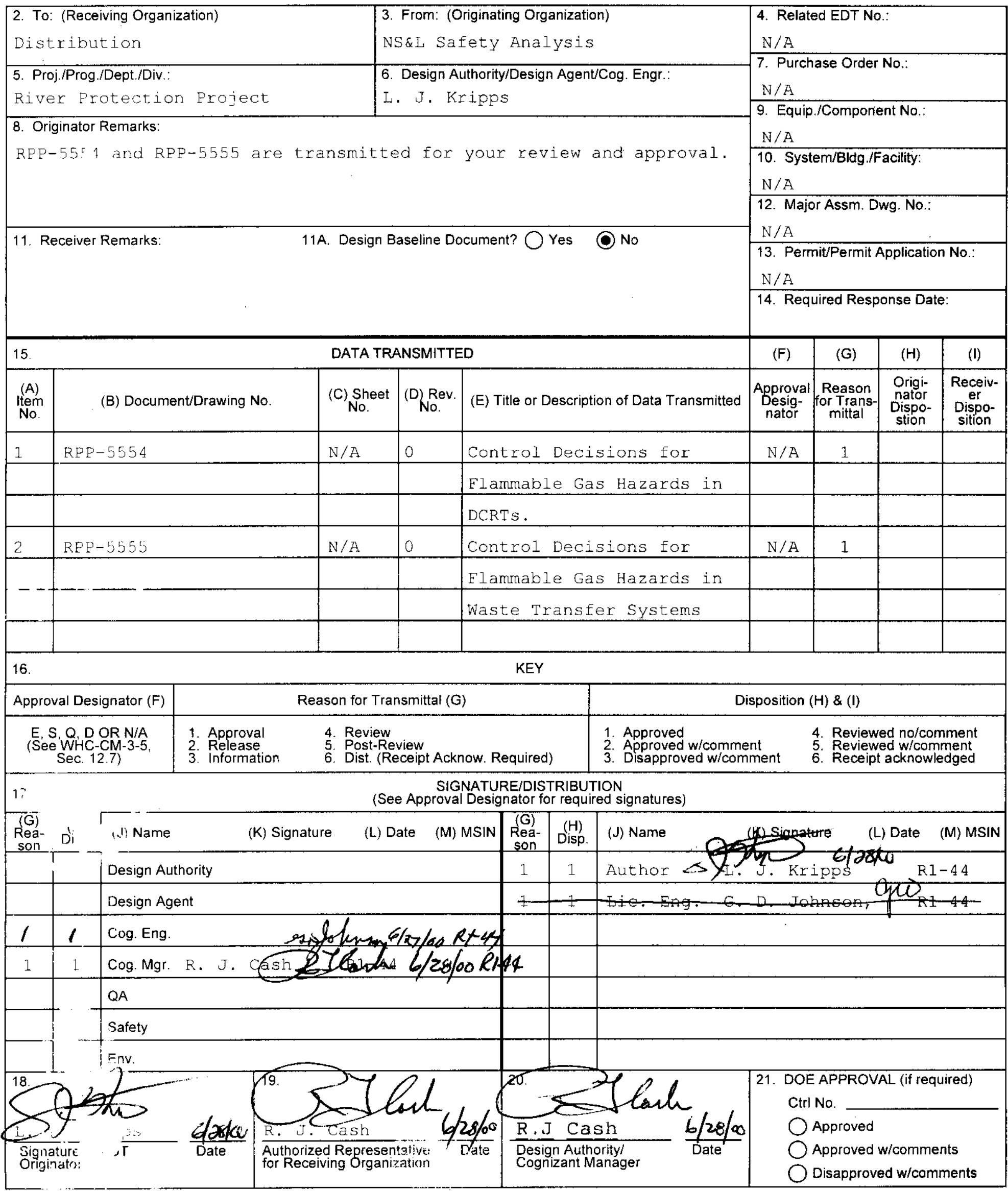




\section{DISTRIBUTION SHEET}

To

Distribution

Project Title/Work Order

RPP-5554, "Control Decisions for Flammable Gas Hazards in Double-Contained Receiver Tanks (DCRTs)"

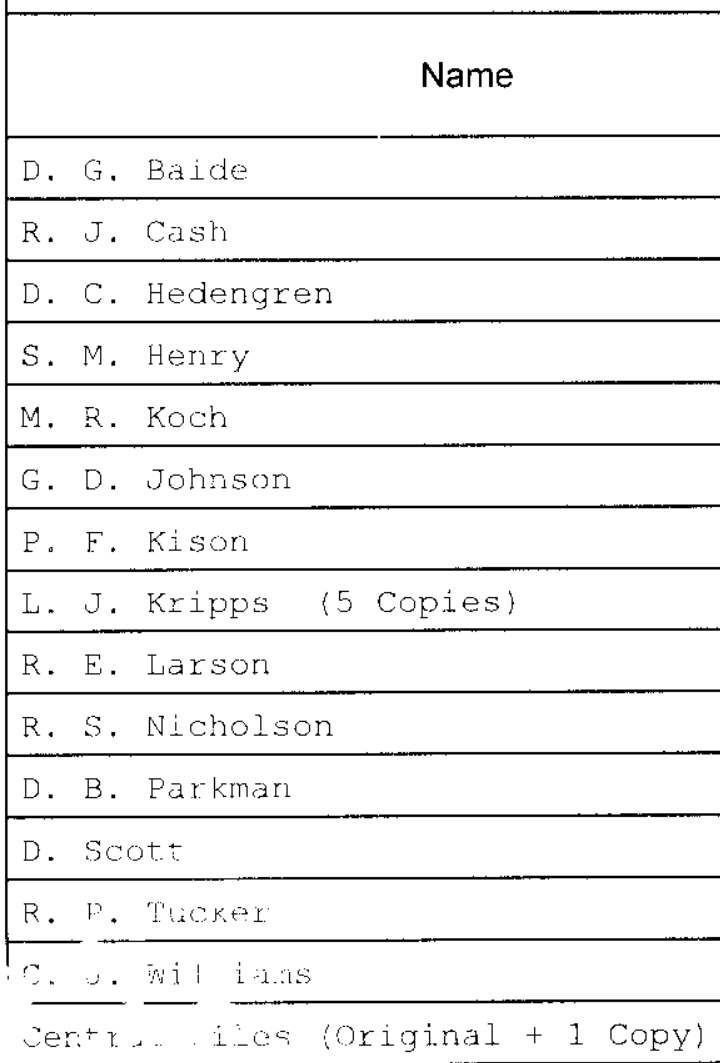

\begin{tabular}{ll|ll} 
From \\
NS\&L/CH2M HILL Hanford Group, Inc.
\end{tabular} $\begin{array}{lll}\text { Page } 1 & \text { of } 1 \\
\text { Date } & \end{array}$

EDT No. 625125

ECN No. N/A

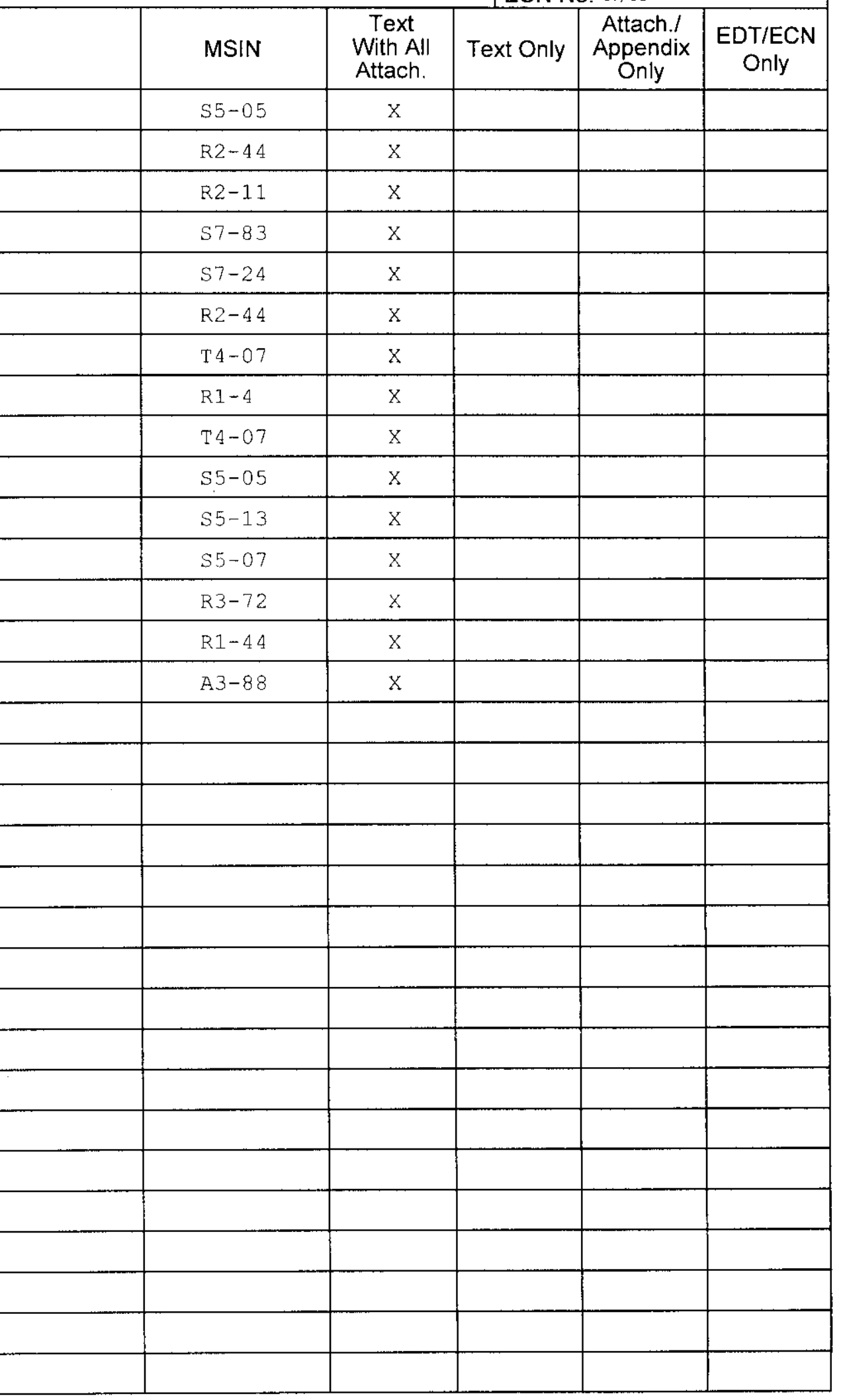




\section{Control Decisions for Flammable Gas Hazards in Double-Contained Receiver Tanks (DCRTs)}

\section{I.J.Kripps}

H\&R Technical Associates

Richland, WA 99352

U.S. Department of Energy Contract DE-AC06-99RL14047

$\begin{array}{lll}\text { EDT/ECN: } & 625125 & \text { UC: } 510 \\ \text { Cost Center: } & 403 & \text { Charge Code: } 109310 \\ \text { B\&R Code: } & \text { N/A } & \text { Total Pages: } 180\end{array}$

Key Words: controls, control decision record, DCRTs, flammable gas, hazards, safety SSCs, TSRs

Abstract: The document summarizes the results of control decision meetings that were conducted to establish revised controls for flammble gas hazards in double-contained receiver tanks (DCRTs).

TRADEMARK DISCLAIMER. Reference herein to any specific commercial product, process, or service by trade name, trademark, manufacturer, or otherwise, does not necessarily constitute or imply its endorsement, recommendation, or favoring by the United States Government or any agency thereof or its contractors or subcontractors.

Printed in the United States of America. To obtain copies of this document, contact: Document Control Services, P.O. Box 950, Mailstop H6-08, Richland WA 99352, Phone (509) 372-2420; Fax (509) 376-4989.
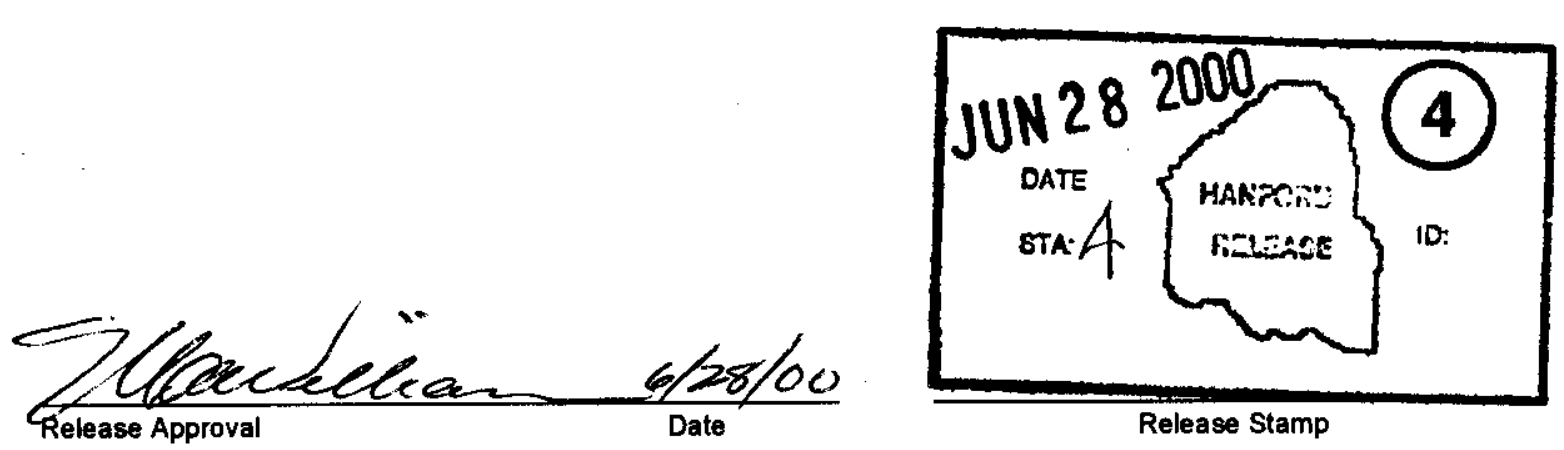

Approved For Public Release 
RPP-5554

Revision 0

\section{Control Decisions for Flammable Gas Hazards in Double-Contained Receiver Tanks (DCRTs)}

Prepared for the U.S. Department of Energy

Assistant Secretary for Environmental Management

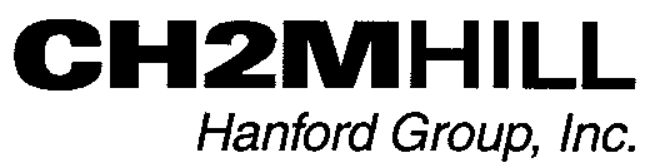

Richland, Washington

Contractor for the U.S. Department of Energy

Office of River Protection under Contract DE-AC06-99RL-14047

Approved for Public Release; Further Dissemination Unlimited 


\section{LEGAL DISCLAIMER}

This report was prepared as an account of work sponsored by an agency of the United States Government. Neither the United States Government nor any agency thereof, nor any of their employees, nor any of their contractors, subcontractors or their employees, makes any warranty, express or implied, or assumes any legal liability or responsibility for the accuracy, completeness, or any third party's use or the results of such use of any information, apparatus, product, or process disclosed, or represents that its use would not infringe privately owned rights. Reference herein to any specific commercial product, process, or service by trade name, trademark, manufacturer, or otherwise, does not necessarily constitute or imply its endorsement, recommendation, or favoring by the United States Government or any agency thereof or its contractors or subcontractors. The views and opinions of authors expressed herein do not necessarily state or reflect those of the United States Government or any agency thereof.

This report has been reproduced from the best available copy. Available in paper copy and microfiche.

Available electronically at http://www.doe.gov/bridge. Available for a processing foe to the U.S. Department of Energy and its contractors, in paper, from:

U.S. Department of Energy

Office of Scientific and Technical Information

P.O. Box 62

Oak Ridge, TN $37831-0062$

phone: $865-576-8401$

fax: $865-576-5728$

email: reports@adonis.osti.gov(423) 576-8401

Available for sale to the public, in paper, from:

U.S. Department of Commerce

National Technical Information Service

5285 Port Royal Road

Springfield, VA 22161

Phone: 800-553-6847

fax: 703-605-6900

email: orders $@$ ntis.fedworld.gov

online ordering:

http://www.ntis.gov/ordering.htm 
RPP-5554

Revision 0

\title{
Control Decisions for Flammable Gas Hazards in Double-Contained Receiver Tanks (DCRTs)
}

\author{
L. J. Kripps
}

H\&R Technical Associates

Date Published

June 2000

Prepared for the U.S. Department of Energy Assistant Secretary for Environmental Management

\section{CH2MHILL \\ Hanford Group, Inc.}

P. O. Box 1500

Richland, Washington

Contractor for the U.S. Department of Energy

Office of River Protection under Contract DE-AC06-99RL14047

Approved for Public Release; Further Dissemination Unlimited 


\section{CONTENTS}

1.0 DOUBLE-CONTAINED RECEIVER TANKS DESCRIPTION ……...................... 1-2

1.1 DOUBLE-CONTAINED RECEIVER TANK 244-A ………........................... 1-2

1.2 DOUBLE-CONTAINED RECEIVER TANK 244-BX ..................................1-3

1.3 DOUBLE-CONTAINED RECEIVER TANK 244-S ...................................... 1-3

1.4 DOUBLE-CONTAINED RECEIVER TANK 244-TX..................................1-3

1.5 DOUBLE-CONTAINED RECEIVER TANK 244-U .................................... 1-3

1.6 244-CR VAULT TANK 003............................................................... 1-4

2.0 POTENTIAL FLAMMABLE GAS HAZARDOUS CONDITIONS ..............................2-1

3.0 RISK OF POSTULATED FLAMMABLE GAS ACCIDENTS ……...........................

4.0 EXISTING AND POSSIBLE FLAMMABLE GAS CONTROLS ................................... 3-4

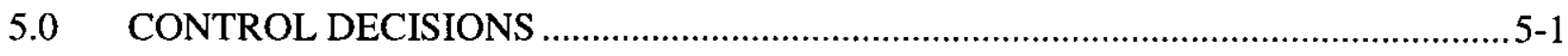

5.1 EXISTING CONTROLS (STATUS QUO) ……......................................... 5-1

5.2 REMOVE FROM SERVICE AND DECONTAMINATION AND

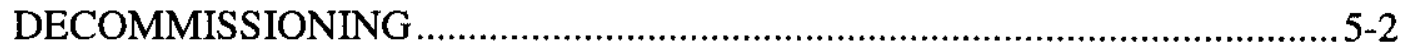

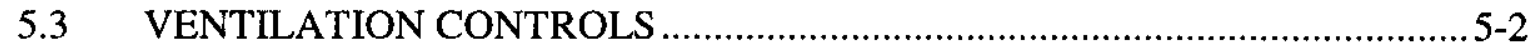

5.4 FLAMMABLE GAS MONITORING CONTROLS .................................... 5-4

5.5 INERTING CONTROL ........................................................................... $5-5$

5.6 DILUTION CONTROLS............................................................................

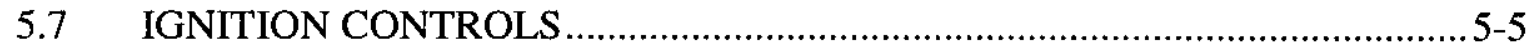

5.8 DCRT VAULT FLAMMABLE GAS CONTROLS .......................................5-5

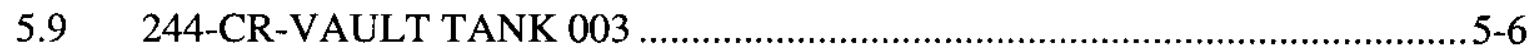

5.10 DCRT 244-S CONTROL STRATEGY …………....................................... 5-6

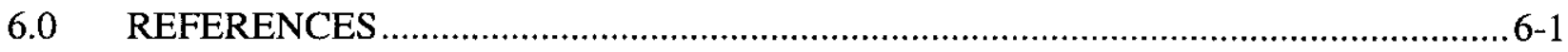

\section{APPENDIX}

A CONTROL DECISION RECORD FOR FLAMMABLE GAS HAZARDS IN DOUBLE-CONTAINED RECEIVER TANKS 


\section{ATTACHMENTS}

1 AGENDA FOR CONTROL DECISION MEETINGS ON NOVEMBER 16, 17, AND 18, 1999 TO ADDRESS DOUBLE-CONTAINED RECEIVER TANKS FLAMMABLE GAS HAZARDS Att 1-i

2 ATTENDANCE LISTS FOR CONTROL DECISION MEETINGS NOVEMBER 16, 17, AND 18, 1999 TO ADDRESS DOUBLE-CONTAINED RECEIVER TANKS FLAMMABLE GAS HAZARDS ..Att 2-i

3 PURPOSE, SCOPE, AND PROCESS FOR CONTROL DECISION MEETINGS TO ADDRESS DOUBLE-CONTAINED RECEIVER TANKS FLAMMABLE GAS HAZARDS Att 3-i

4 NOVEMBER 16, 1999 CONTROL DECISION MEETING PRESENTATIONS ....Att 4-i

5 CONTROL DECISION MEETING ON APRIL 19, 2000 TO ADDRESS FLAMMABLE GAS HAZARDS IN DCRTS AND WASTE TRANSFER SYSTEMS Att 5-i

6 CONTROL DECISION MEETING ON MAY 10, 2000 TO ADDRESS FLAMMABLE GAS HAZARDS IN 244-CR VAULT TANK 003 Att 6-i

\section{FIGURES}

Figure 1-1. Typical Double-Contained Receiver Tank (244-S; 244-A similar but smaller). $1-5$

Figure 1-2. Typical Double-Contained Receiver Tank (244-BX, 244-TX, and 244-U)..............1-6

\section{TABLES}

Table 1-1. Double-Contained Receiver Tanks Location, Capacity, and Configuration $1-7$

Table 1-2. Current and Planned Future Use of Double-Contained Receiver Tanks. $1-8$

Table 2-1. Potential Flammable Gas Hazardous Conditions in Double-Contained Receiver Tanks with Significant Consequences to Onsite Workers (S2) and the Offsite Public (S3).

Table 3-1. Existing and New Double-Contained Receiver Tank Consequence Analyses. 3-3

Table 4-1. Possible Double-Contained Receiver Tank 244-A Control Decisions. 4-4

Table 4-2. Possible DCRT 244-BX Control Decisions. 4-9 
Table 4-3. Possible DCRT 244-S Control Decisions.............................................................. 4-14

Table 4-4. Possible DCRT 244-TX Control Decisions............................................................... 4-20

Table 4-5. Possible DCRT 244-U Control Decisions. ………................................................. 4-25

Table 4-6. Summary of DCRT Flammable Gas Calculations Supporting the Revision to TSR LCO 3.2.4 "DCRT Ventilation Systems"

Table 4-7. Summary of DCRT Flammable Gas Calculations Supporting the Revision to TSR AC 5.11 "Flammable Gas Monitoring Controls".

Table 4-8. Summary of DCRT Vault Flammable Gas Concentrations...................................... 4-33 


\section{LIST OF TERMS}

AC

ALARA

D\&D

DCRT

DOE

DST

FSAR

GRE

HEPA

LCO

LFL

O\&M

ORP

PFP

PNNL

RCRA

SHMS

$\mathrm{SC}$

SSC

SST

TSR

TWRS

USQ
Administrative Control

as low as reasonably achievable

decontamination and decommissioning

double-contained receiver tank

U.S. Department of Energy

double-shell tank

Final Safety Analysis Report

gas release event

high-efficiency particulate air (filter)

limiting condition for operation

lower flammability limit

operations and maintenance

Office of River Protection

Plutonium Finishing Plant

Pacific Northwest National Laboratory

Resource Conservation and Recovery Act of 1976

Standard Hydrogen Monitoring System

Safety-Class

structure, system, and component

single-shell tank

Technical Safety Requirement

Tank Waste Remediation System

Unreviewed Safety Question 


\section{CONTROL DECISIONS FOR FLAMMABLE GAS HAZARDS IN DOUBLE-CONTAINED RECEIVER TANKS}

This report describes the control decisions for flammable gas hazards in double-contained receiver tanks (DCRTs) made at control decision meetings on November 16, 17, and 18, 1999, on April 19, 2000, and on May 10, 2000, and their basis. These control decisions, and the analyses that support them, will be documented in an amendment to the Final Safety Analysis Report (FSAR) (CHG 2000a) and Technical Safety Requirements (TSR) (CHG 2000b) to close the Flammable Gas Unreviewed Safety Question (USQ) (Bacon 1996 and Wagoner 1996) for DCRTs. Following the contractor Tier I review of the FSAR and TSR amendment, it will be submitted to the U.S. Department of Energy (DOE), Office of River Protection (ORP) for review and approval.

The control decision meetings on November 16, 17, and 18,1999, to address flammable gas hazards in DCRTs, followed the control decision process and the criteria for control decisions described in Section 3.3.1.5 of the FSAR. The control decision meeting agenda, attendance lists, and the introductory and background presentations on November 16, 1999, are included in Attachments 1 through 4. The control decision discussions on November 17 and 18, 1999, on existing and possible controls for flammable gas hazards in DCRTs and the basis for selecting or not selecting specific controls, are summarized in this report.

The agenda, attendance list, and the purpose, scope, and process for the April 19, 2000 control decision meeting, and the presentations at that meeting related to flammable gas hazards in DCRTs are included in Attachment 5. At this control decision meeting previous control decisions were reviewed and revised based on revisions to the DCRT flammable gas accident analysis presented at the November 16,17, and 18, 1999 meetings and on new predictions of flammable gas concentrations that incorporated new ammonia solubility data. These control decision discussions are summarized in this report.

Attachment 6 contains the attendance list and the results of flammable gas concentration predictions that were presented to support control decisions at the May 20, 2000 meeting for flammable gas hazards in 244-CR Vault Tank 003. These control decision discussions are summarized in this report.

Section 1.0 describes the DCRTs that are included within the scope of the control decisions documented in this report. The focus of Section 1.0 is the current and future planned use of DCRTs. Sections 2.0 and 3.0 summarize the hazard and accident analyses of flammable gas hazards in DCRTs that supported the control decisions. Existing and possible controls that were considered to prevent or mitigate DCRT flammable gas hazards are identified and discussed in Section 4.0. Section 5.0 summarizes the control decisions and the basis for the selected controls. 


\subsection{DOUBLE-CONTAINED RECEIVER TANKS DESCRIPTION}

DCRTs are interim, short-term (lag) storage facilities and valve pits for waste transfer operations. A DCRT typically consists of an underground concrete structure that contains a vault in which the receiver tank is installed and associated filter pit, pump pit, instrument pit, and/or flush pit (see Figures 1-1 and 1-2). DCRTs include 244-A and 244-BX located in the 200 East Area and 244-S, 244-TX, and 244-U located in the 200 West Area. The 244-CR Vault located in the 200 East Area also contains one tank (Tank 003) that is identified in the FSAR as a DCRT. ${ }^{a}$ Table 1-1 summarizes information on the location, capacity, configuration, and operation date of these DCRTs.

DCRTs 244-A, 244-BX, 244-S, 244-TX, and 244-U each have a ventilation system with an exhaust fan that provides flow through the DCRT vault and suction to the receiver tank. Except for DCRT 244-U, which has a filtered inlet path to the receiver tank, there is no designed inlet flow path to the DCRT receiver tanks. Because of the DCRT ventilation system design, the ventilation flow through the receiver tanks cannot be measured and is unknown. ${ }^{b}$ The only assured flow to the DCRT receiver tanks is provided by instrument air injected via three small pipes (known as dip-tubes) as part of the DCRT weight factor and specific gravity liquid-level monitoring system.

Additional design information on the DCRTs, including 244-CR Vault Tank 003, and their ventilation systems is contained in Section 2.4.5 of the FSAR.

Because of its importance to potential flammable gas hazard control decisions, the current and planned future use of each DCRT is described below and summarized in Table 1-2.

\subsection{DOUBLE-CONTAINED RECEIVER TANK 244-A}

DCRT 244-A is a lift station located at a low point in the 200 East Area waste transfer system. It serves as a catch tank for waste transfers which pass through the 244-A pump pit (i.e., cross-site transfers and transfers from DCRT 244-BX). That is, it receives drainage from transfer line holdup when jumpers are changed and also would receive waste from transfer line leaks. The W-314 project plans include construction of a cross-site transfer line bypass around DCRT 244-A, but the schedule for completion of this bypass is not certain.

\footnotetext{
${ }^{a}$ The 244-CR Vault Tank 003 was not included in the scope of the November 16, 17, and 18, 1999 control decision meetings, but was addressed at the April 19 and May 20, 2000 control decision meetings.

b HNF-2923, Headspace Gas Concentration Measurements and Headspace Ventilation Rate Measurements for Double-Contained Receiver Tanks 241-A-244, 241-BX-244, 241-S-244, and 241-TX-244, Revision 0-B, Lockheed Martin Hanford Corporation, September 1999, reports the results of ventilation rates estimated for DCRTs based on the measured decay rate of tracer gas injected as part of a test. Ventilation rate measurements ranged from $0.45 \mathrm{cfm}$ to $14 \mathrm{cfm}$.
} 


\subsection{DOUBLE-CONTAINED RECEIVER TANK 244-BX}

DCRT 244-BX will receive waste from salt well pumping of Tanks 241-BY-105 and 241-BY-106. The salt well pumping of these tanks is scheduled to start in early calendar year 2001 and be completed by mid-calendar year 2003. This schedule meets the consent decree schedule for the completion of single-shell tank (SST) interim stabilization which calls for the pumping of Tanks 241-BY-105 and 241-BY-106 to be initiated by July 15, 2001, with projected pumping completion by June 30, 2003.

\subsection{DOUBLE-CONTAINED RECEIVER TANK 244-S}

DCRT 244-S receives waste transfers from the 222-S Laboratory, may receive waste from salt well pumping of 241-S and 241-SX Tank Farm tanks (backup route ${ }^{\mathfrak{c}}$ ), and could receive waste from pumping out catch tanks 241-UX-302A and 241-S-304. DCRT 244-S also serves as a catch tank for DCRT 244-TX transfers which pass through the 244-S pump pit (i.e., receives drainage from DCRT 244-TX transfer line holdup when jumpers are changed and also would receive waste from DCRT 244-TX transfer line leaks).

Waste transfers from the 222-S Laboratory are planned to continue for the next 20 to 30 years, but salt well transfers from 241-S or 241-SX Tank Farm tanks are scheduled to be completed by late calendar year 2003. (Note: The consent decree schedule for SST interim stabilization requires all salt well pumping to be completed by September 30, 2004). The W-314 project plans include an upgrade to the DCRT 244-S ventilation system to meet environmental requirements, but the schedule for completion of this upgrade is not certain. Because of the high estimated costs to meet environmental requirements for continuing long-term use of DCRT 244-S for 222-S Laboratory waste transfers, alternatives that would bypass DCRT 244-S are being considered.

\subsection{DOUBLE-CONTAINED RECEIVER TANK 244-TX}

Salt well pumping of Tank 241-T-104 and Tank 241-T-110 is complete. Therefore, DCRT 244-TX only receives waste from the Plutonium Finishing Plant (PFP). Because the plans for PFP waste transfers extend beyond the date when DCRT 244-TX transfer lines (incoming and outgoing) would have to be upgraded to meet the Resource Conservation and Recovery Act of 1976 (RCRA) requirements, alternative methods of transferring PFP waste to tank farm facilities are being considered (e.g., by truck).

\subsection{DOUBLE-CONTAINED RECEIVER TANK 244-U}

DCRT 244-U may receive waste from salt well pumping of 241-U Tank Farm tanks (backup route $^{\mathrm{d}}$ ) and could receive waste from pumping out catch tank 241-U-301B. (Note: DCRT 244-U

\footnotetext{
c The planned transfer route for salt well pumping of 241-S and 241-SX Tank Farm tanks bypasses DCRT 244-S. However, DCRT 244-S is considered as a backup route.

d The planned transfer route for salt well pumping of 241-U Tank Farm tanks bypasses DCRT 244-U. However, DCRT $244-\mathrm{U}$ is considered as a backup route.
} 


\section{RPP-5554 REV 0}

has never been placed into service and contains only water.) The salt well pumping of 241-U Tank Farm tanks is ongoing and is scheduled to be completed by mid-calendar year 2003 . This schedule meets the consent decree schedule for the completion of all SST interim stabilization by September 30, 2004.

\section{$1.6 \quad 244-C R$ VAULT TANK 003}

244-CR Vault Tank 003 is identified in the FSAR as a DCRT based on its potential use for short-term storage of salt well waste from the 241-C Tank Farm. Tank 241-C-103 is the only tank remaining in the 241-C Tank Farm requiring interim stabilization (i.e., salt well pumping). Because this tank contains a floating organic layer, it is considered unlikely that DCRT 244-CR-003 would be used for transferring the organic layer or the pumpable liquids from this tank. The only waste transfers to 244-CR Vault Tank 003 expected are transfers of pumpable liquids from other 244-CR Vault tanks and sumps that are planned for interim stabilization of the 244-CR Vault. 
Figure 1-1. Typical Double-Contained Receiver Tank (244-S; 244-A similar but smaller).

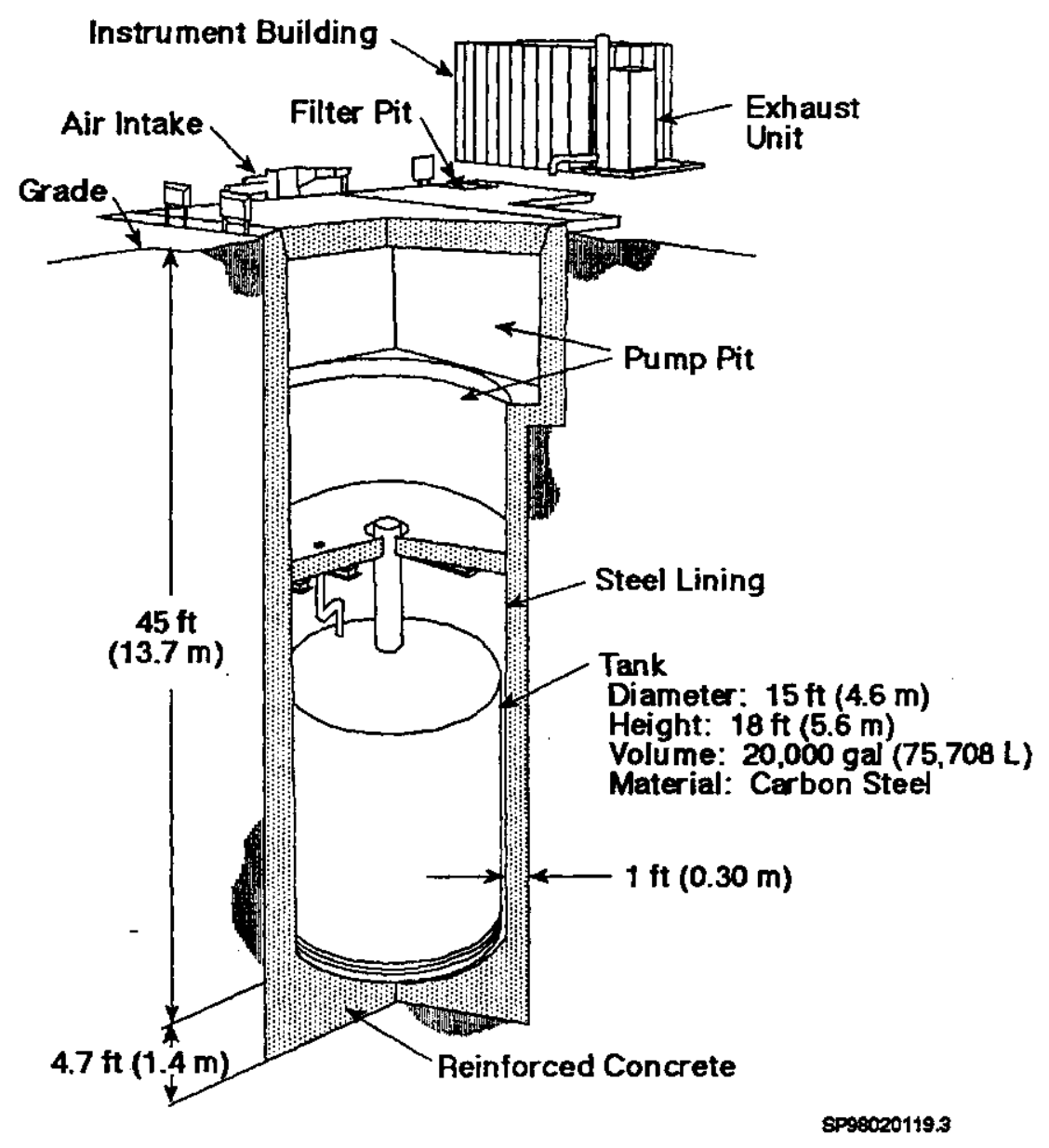


Figure 1-2. Typical Double-Contained Receiver Tank (244-BX, 244-TX, and 244-U).

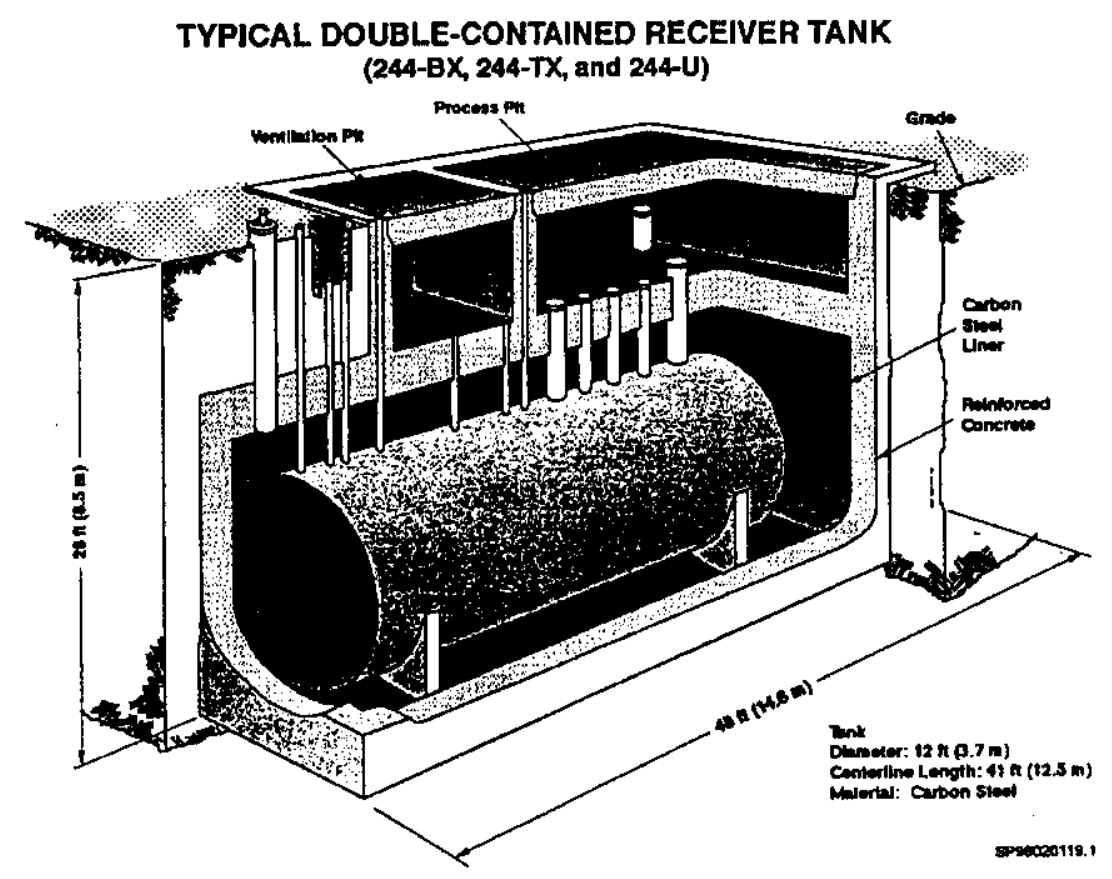




\section{RPP-5554 REV 0}

Table 1-1. Double-Contained Receiver Tanks Location, Capacity, and Configuration

\begin{tabular}{|c|c|c|c|c|}
\hline DCRT & Location & Capacity & Configuration & Operation Date \\
\hline 244-A & $\begin{array}{l}\text { 200 East Area - West of } \\
\text { the 241-AN Tank Farm }\end{array}$ & $\begin{array}{l}61,627 \mathrm{~L} \\
(16,280 \mathrm{gal})\end{array}$ & $\begin{array}{l}\text { Vertical receiver tank design } \\
\text { similar to but smaller than } \\
\text { DCRT } 244-S \text { (see Figure } 1-1 \text { ) }\end{array}$ & 1975 \\
\hline 244-BX & $\begin{array}{l}200 \text { East Area - East of } \\
\text { Tank } 241-B X-102 \text { in the } \\
241-B X \text { Tank Farm }\end{array}$ & $\begin{array}{l}117,350 \mathrm{~L} \\
(31,000 \mathrm{gal})\end{array}$ & $\begin{array}{l}\text { Horizontal receiver tank design } \\
\text { similar to DCRTs } 244-T X \text { and } \\
244-\mathrm{U} \text { (see Figure 1-2) }\end{array}$ & 1981 \\
\hline $244-S$ & $\begin{array}{l}200 \text { West Area - South } \\
\text { of the } 241-S Y \text { Tank } \\
\text { Farm and east of } 13^{\text {th }} \\
\text { Street }\end{array}$ & $\begin{array}{l}76,768 \mathrm{~L} \\
(20,280 \mathrm{gal})\end{array}$ & $\begin{array}{l}\text { Vertical receiver tank design } \\
\text { similar to but larger than DCRT } \\
\text { 244-A (see Figure 1-1) }\end{array}$ & 1978 \\
\hline 244-TX & $\begin{array}{l}200 \text { West Area - North } \\
\text { of 241-TX Tank Farm }\end{array}$ & $\begin{array}{l}117,350 \mathrm{~L} \\
(31,000 \mathrm{gal})\end{array}$ & $\begin{array}{l}\text { Horizontal receiver tank design } \\
\text { similar to DCRTs } 244-\mathrm{BX} \text { and } \\
244-\mathrm{U} \text { (see Figure 1-2) }\end{array}$ & 1981 \\
\hline $244-U$ & $\begin{array}{l}200 \text { West Area - } \\
\text { Southeast of Tank } \\
241-U-110 \text { in the } 241-U \\
\text { Tank Farm }\end{array}$ & $\begin{array}{l}117,350 \mathrm{~L} \\
(31,000 \mathrm{gal})\end{array}$ & $\begin{array}{l}\text { Horizontal receiver tank design } \\
\text { similar to DCRTs } 244-B X \text { and } \\
\text { 244-TX (see Figure 1-2). } \\
\text { (Note: DCRT 244-U has the } \\
\text { only receiver tank with a } \\
\text { filtered inlet.) }\end{array}$ & a \\
\hline $\begin{array}{l}244-\mathrm{CR} \\
\text { Vault } \\
\text { Tank } \\
003\end{array}$ & $\begin{array}{l}200 \text { East Area - South of } \\
\text { the 241-C Tank Farm }\end{array}$ & $\begin{array}{l}56,781 \mathrm{~L} \\
(15,000 \mathrm{gal})\end{array}$ & Vertical receiver tank design & 1952 \\
\hline
\end{tabular}

${ }^{2}$ DCRT 244-U was constructed in 1978, but has never been placed into operation.

DCRT $=$ double-contained receiver tank. 
Table 1-2. Current and Planned Future Use of Double-Contained Receiver Tanks.

\begin{tabular}{|c|c|}
\hline DCRT & Use \\
\hline $244-\mathrm{A}$ & $\begin{array}{l}\text { Serves as a catch tank for waste transfers which pass through the 244-A pump pit } \\
\text { (i.e., cross-site transfers and transfers from DCRT } 244-\mathrm{BX} \text { ). That is, receives drainage from } \\
\text { transfer line holdup when jumpers are changed and also would receive waste from transfer } \\
\text { line leaks. }\end{array}$ \\
\hline 244-BX & $\begin{array}{l}\text { Receives Tank } 241-B Y-105 \text { and Tank } 241-B Y-106 \text { salt well waste from the interim } \\
\text { stabilization of these tanks. }\end{array}$ \\
\hline $244-S$ & $\begin{array}{l}\text { - } \quad \text { Receives 222-S Laboratory waste. } \\
\text { May receive 241-S and 241-SX Tank Farm tank salt well waste from the interim } \\
\text { stabilization of these tanks (backup route). } \\
\text { - } \quad \text { Could receive waste from catch tanks 241-UX-302A and 241-S-304. } \\
\text { - Serves as a catch tank for DCRT 244-TX transfers which pass through the 244-S pump } \\
\text { pit (i.e., receives drainage from DCRT 244-TX transfer line holdup when jumpers are } \\
\text { changed and also would receive waste from DCRT 244-TX transfer line leaks). }\end{array}$ \\
\hline 244-TX & Receives Plutonium Finishing Plant waste. \\
\hline $244-U$ & $\begin{array}{l}\text { May receive } 241-\mathrm{U} \text { Tank Farm tank salt well waste from the interim stabilization of } \\
\text { these tanks (backup route). } \\
\text { - Could receive waste from catch tank 241-U-301B. }\end{array}$ \\
\hline $\begin{array}{l}\text { 244-CR Vault } \\
\text { Tank } 003\end{array}$ & $\begin{array}{l}\text { Previously planned to receive salt well waste from the } 241-C \text { Tank Farm. Currently } \\
\text { there are no plans to use this tank for any future mission, except for interim stabilization } \\
\text { of the } 244-C R \text { Vault. }\end{array}$ \\
\hline
\end{tabular}

DCRT $=$ double-contained receiver tank. 


\subsection{POTENTIAL FLAMMABLE GAS HAZARDOUS CONDITIONS}

Flammable gases (e.g., hydrogen, ammonia, methane) may enter and accumulate in the headspace of DCRT receiver tanks by one of three processes: (1) transferred in with the waste (e.g., soluble gases, gas bubbles); (2) produced in the tank during waste storage by radiolysis of water and organics, chemical reactions (or thermolysis), and corrosion processes; and (3) produced by chemical adjustments of the waste before transfer to a double-shell tank (DST) (e.g., ammonia release) (PNNL 1998, LMHC 1999a, and CHG 2000). The Authorization Basis hazard analysis data base identifies a number of potential flammable gas hazardous conditions caused by these steady-state (or chronic) flammable gas release mechanisms with significant onsite worker or offsite public consequences (see Table 2-1). No potential flammable gas hazardous conditions are identified with significant facility worker consequences and with an uncontrolled frequency of anticipated (i.e., $10^{-2}$ to $10^{0}$ per year).

Based on Pacific Northwest National Laboratory (PNNL) analysis of the potential for gas retention in a DCRT nonconvective layer ${ }^{\mathrm{e}}$ (see Section 6.0 of PNNL 1998), there is no significant risk from gas release events (GREs) in DCRTs 244-A, 244-BX, 244-S, 244-TX, and 244-U. The PNNL analysis showed that relatively large, sudden gas releases are theoretically possible only in DCRTs 244-S and 244-U. In these DCRTs, however, even the largest theoretical gas releases would not cause the DCRT receiver tank headspace to exceed the lower flammability limit (LFL), but it could exceed $25 \%$ of the LFL.

Due to the remaining sludge heel in 244-CR Vault Tank 003, this tank is conservatively categorized as a Facility Group 3 Tank. That is, there is a potential hazard from releasing flammable gases that may be retained by the waste solids during waste disturbing operations (FSAR Appendix K).

One additional potential flammable gas hazardous condition was identified and considered at the April 19, 2000 control decision meeting. This hazardous condition is the generation and accumulation of flammable gas in a DCRT vault caused by a tank leak or failure.

\footnotetext{
${ }^{\mathrm{e}}$ Flammable gas that is generated by radiolysis and chemical reactions can accumulate in a nonconvective solid-liquid matrix that forms as solid particles settle out of or precipitate from a waste slurry. If sufficient gas is retained to make the nonconvective layer buoyant, a buoyant displacement instability may occur that can release a large fraction of the retained gas into the tank's headspace [i.e., a gas release event (GRE)]. Even if the nonconvective layer does not become buoyant, its retained gas can be released if the waste matrix is disrupted.
} 
RPP-5554 REV 0

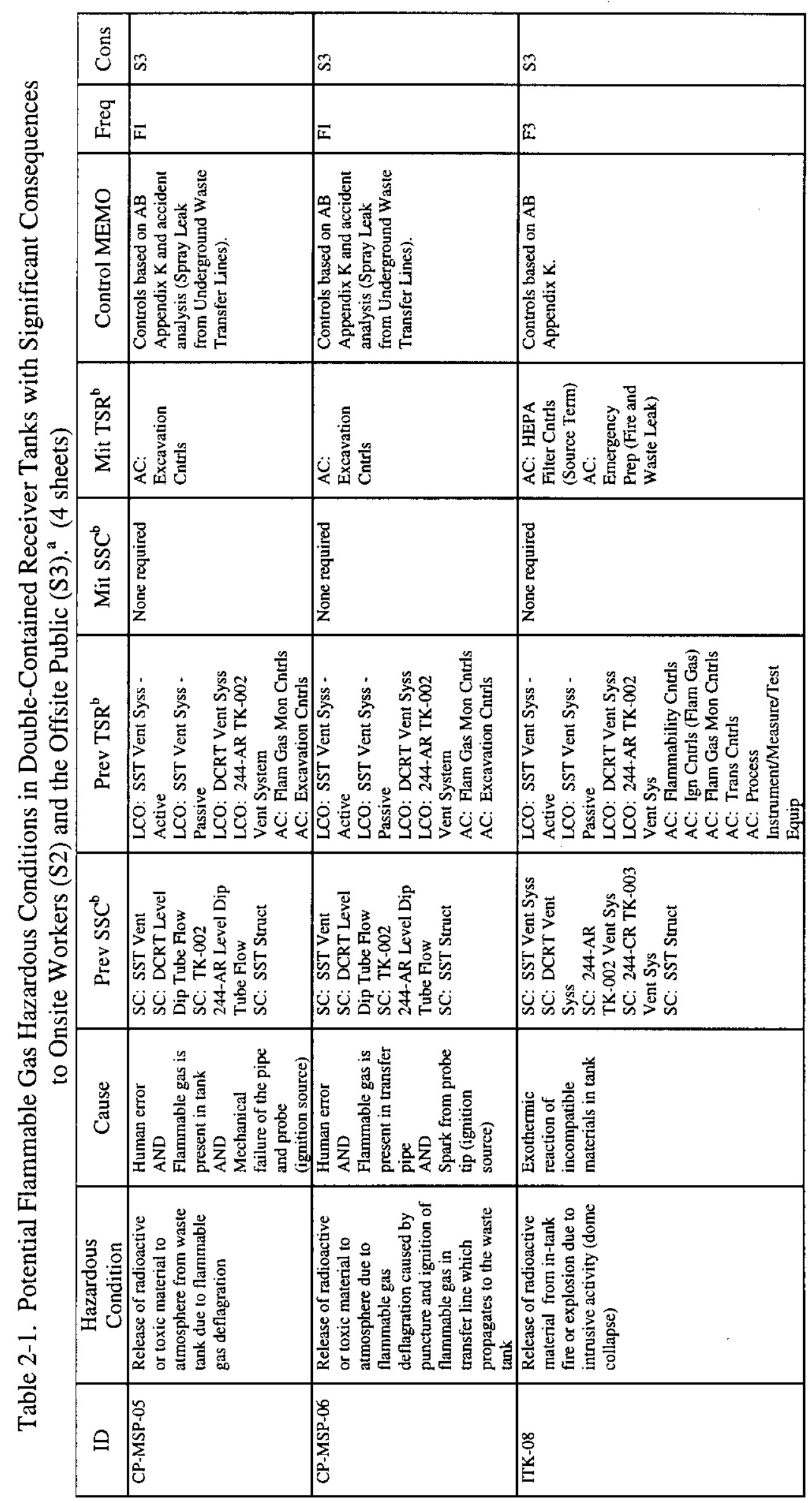


RPP-5554 REV 0

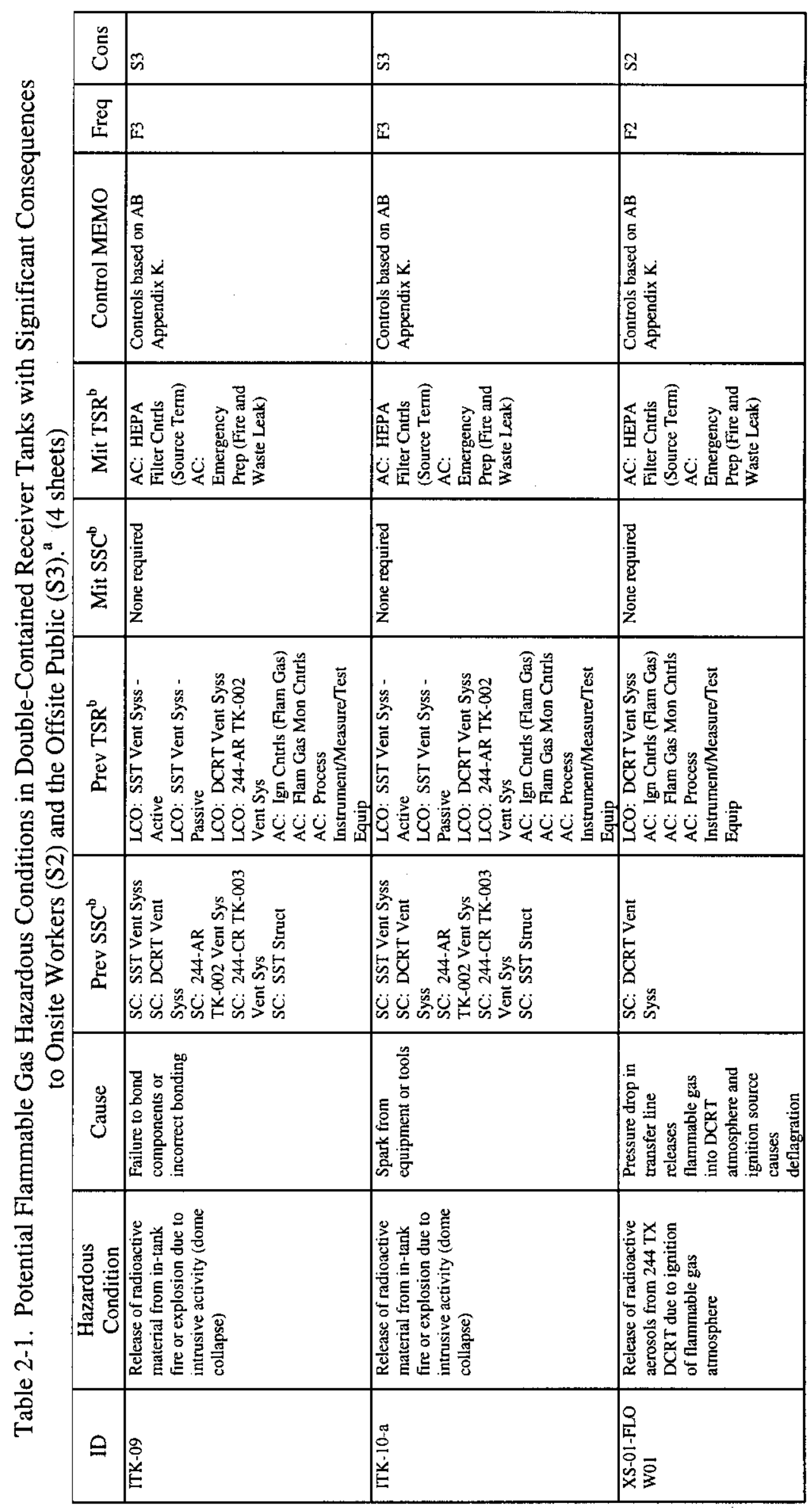


RPP-5554 REV 0

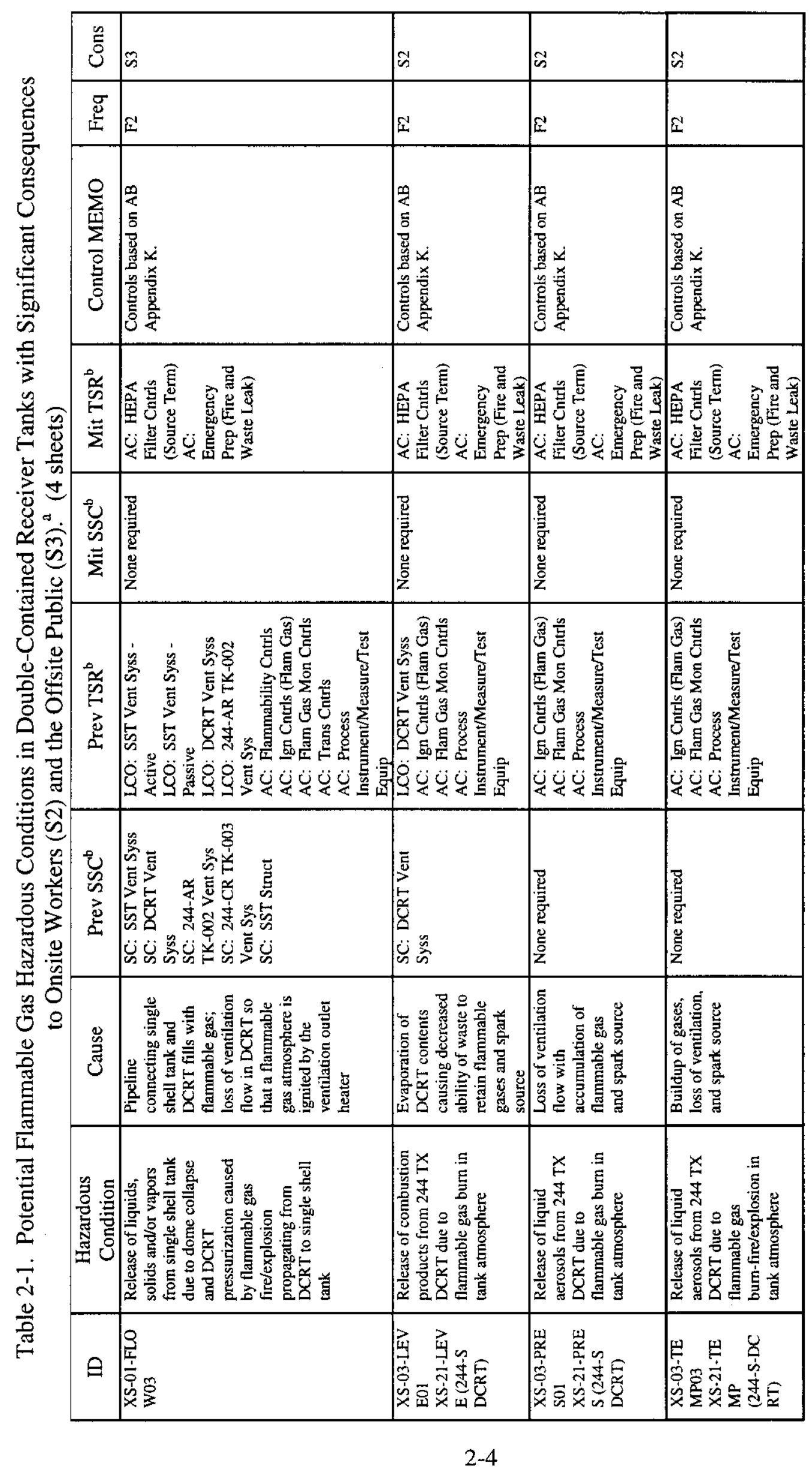




\section{RPP-5554 REV 0}
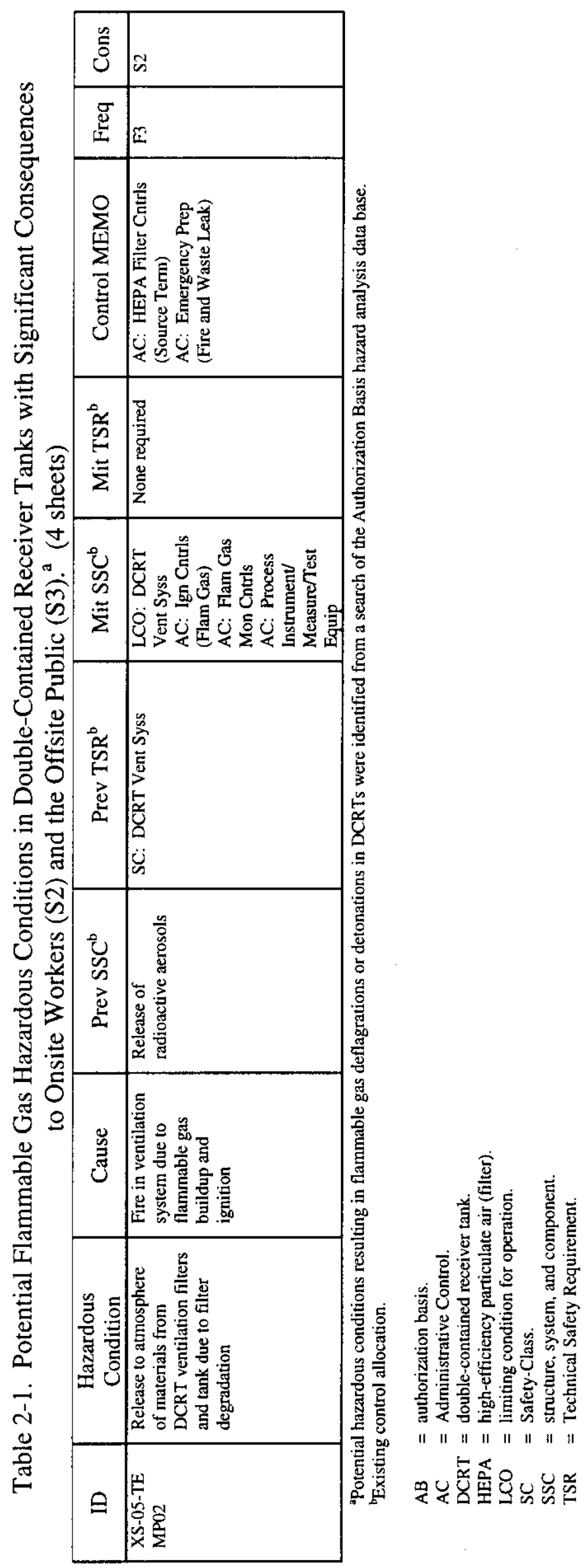
RPP-5554 REV 0

This page intentionally left blank. 


\subsection{RISK OF POSTULATED FLAMMABLE GAS ACCIDENTS}

The postulated accident scenario is the steady state generation of flammable gases in the headspace of a DCRT receiver tank that because of insufficient ventilation accumulates to a concentration above the LFL. An ignition source then causes a deflagration or detonation. The frequency of this postulated accident without controls is conservatively assumed to be anticipated (i.e., $10^{-2}$ to $10^{\circ}$ per year) for a deflagration and unlikely (i.e., $10^{-4}$ to $10^{-2}$ per year) for a detonation (FFS 2000).

The FSAR includes a consequence analysis of a postulated flammable gas deflagration accident in a DCRT. Consequences are calculated for a flammable gas deflagration that causes receiver tank failure. All of the releases from the pressurized venting of the receiver tank are assumed to be released directly to the environment [18.3 liters of respirable waste composed of 95\% SST liquids and 5\% SST solids] (WHC 1996). The FSAR DCRT flammable gas accident results are shown in Table 3-1 and indicate that radiological doses and toxicological exposures could exceed offsite and onsite risk evaluation guidelines. See FSAR Section 3.4.2 for additional information.

Additional consequence analysis was performed to support the closure of the Flammable Gas USQ for DCRTs. The original revised analysis in HNF-4526, Combustion Accident Analysis for Double-Contained Receiver Tanks (DCRTs) 244-S and 244-TX (FDNW 1999) provided conservatively bounding estimates of releases to the environment from a deflagration and a detonation within a DCRT and then used the established FSAR methodology to estimate the consequences associated with these releases. The accident was analyzed as a sequence of three processes: (1) a rapid combustion process leading to a maximum pressure and temperature for the gas mixture in the receiver tank headspace, (2) the rapid opening of receiver tank depressurization paths, and (3) the subsequent depressurization (or blow-down) of the system and releases to the environment. Conservative and defendable estimates for the pre-combustion inventories, filter inventories, and mass entrained during a deflagration event were established. Also, reasonably conservative estimates for deflagration and detonation entrainment were taken from DOE-HDBK-3010-94, Airborne Release Fractions/Rates and Respirable Fractions for Nonreactor Nuclear Facilities (DOE 1994). The HADCRT computer code was used to calculate the mass transport to the environment during the depressurization of the system. The transport mechanisms are well established and validated for simple systems, and included material depletion mechanisms.

Subsequent to the original revised analysis in HNF-4526, a limited review and revision of this conservatively bounding analysis was performed to provide a more reasonably conservative estimate of potential consequences (RPP-6244, Updated Double-Contained Receiver Tank Combustion Accident Analysis [FFS 2000]). Improvements in the analysis to remove conservatism focused on the modeling of blowdown entrainment, which was a significant source of material release in HNF-4526, and the application of newly developed radiological source terms, air transport, and plume depletion factors for calculating the consequences from material releases. 
The results from the DCRT flammable gas accident analysis in RPP-6244 are shown in Table 3-1. The results show that postulated flammable gas accidents in DCRTs do not challenge offsite risk guidelines, but do exceed onsite risk guidelines. This means that structures, systems, and components (SSCs) selected to prevent or mitigate postulated DCRT flammable gas accidents are classified as safety-significant. RPP-6244 also concluded that based on a comparison of the design of 244-CR Vault Tank 003 to DCRT 244-S, it is expected that a flammable gas accident in the headspace of 244-CR Vault Tank 003 would lead to environmental releases and consequences similar to those calculated for DCRT 244-S. 


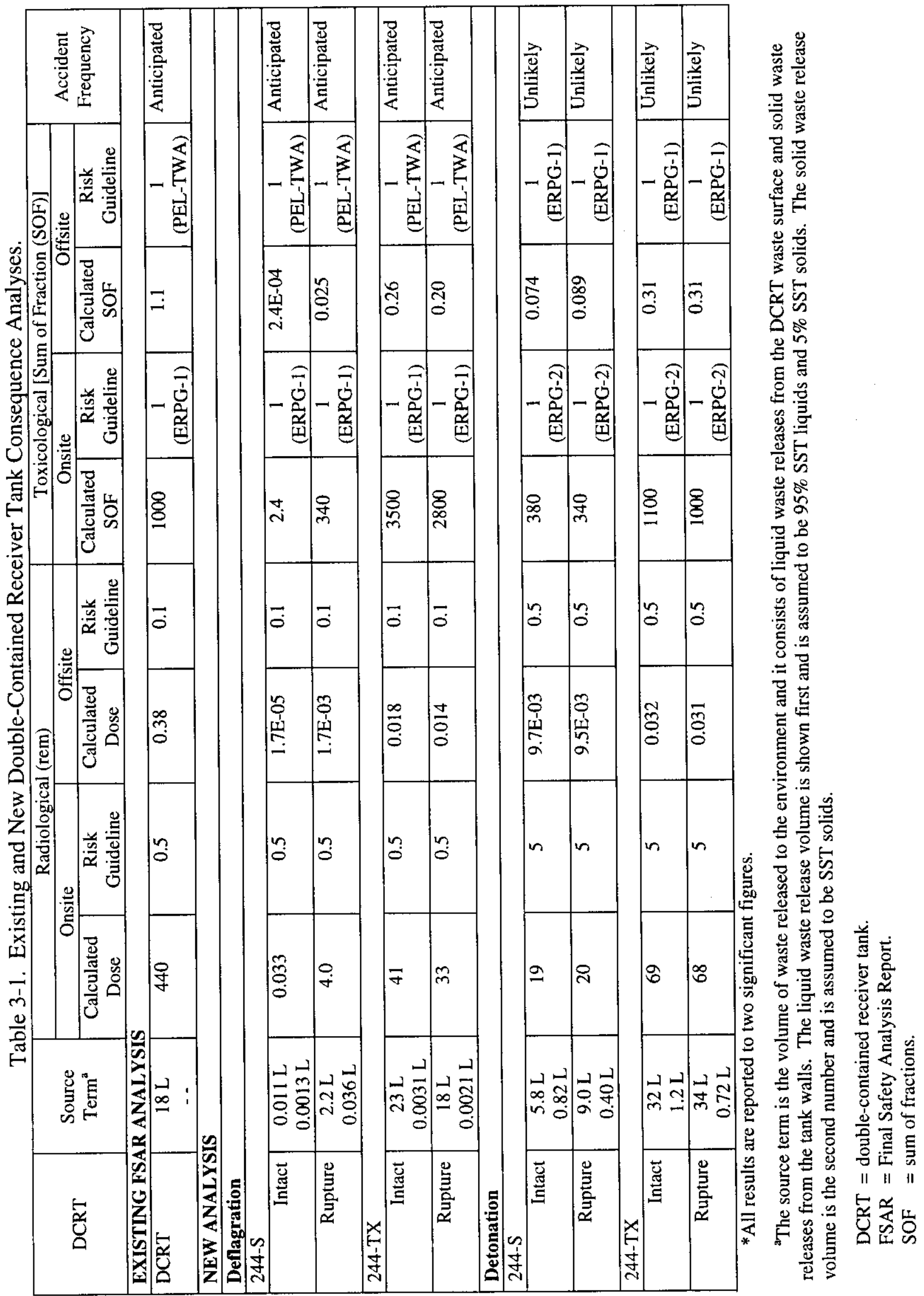




\section{RPP-5554 REV 0}

This page intentionally left blank. 


\subsection{EXISTING AND POSSIBLE FLAMMABLE GAS CONTROLS}

This section identifies the existing controls and other possible controls that could prevent or mitigate flammable gas hazards that were considered at the November 16,17, and 18, 1999, the April 19, 2000, and the May 20, 2000 control decision meetings. For each existing and possible control, thoughts for and against the control are presented. Additional information on the cost, schedule, ALARA concerns, technical feasibility, and operability and maintainability of alternative DCRT ventilation system and/or flammable gas monitoring modifications is contained in RPP-5162, Evaluation of Flammable Gas Monitoring and Ventilation System Alternatives for Double-Contained Receiver Tanks (LMHC 1999b).

Existing controls for flammable gas hazards in DCRTs include the following.

- DCRT ventilation system flow rate requirements (TSRs LCO 3.2.4, AC 5.11.2d, and AC 5.12.2.c fourth bullet)

- DCRTs 244-A, 244-BX, 244-S, 244-TX, and 244-U, are in the Flammable Gas Facility Group Non-GRE and 244-CR Vault Tank 003 is in Flammable Gas Facility Group 3 (TSR AC 5.9.2.b, Table 5.9-1)

- For DCRTs 244-A, 244-BX, 244-S, 244-TX, and 244-U, Ignition Source Control Set 2 applies to activity-related equipment and materials until work activity entry monitoring requirements are met. Ignition source controls during entry monitoring are not required in the ex-tank intrusive region. In addition, for 244-CR Vault Tank 003 there are additional ignition and flammable gas monitoring requirements for waste intruding equipment and during waste disturbing activities. ( See TSRs AC 5.10, Table 5.10-1; and AC 5.11, Table 5.11-1).

Note: There are no ignition source controls on installed DCRT equipment.

The following tables summarize thoughts for and against the above existing controls and other possible controls considered at the control decision meetings on November 16, 17, and 18, 2000.

$$
\begin{aligned}
& \text { DCRT 244-A }- \text { See Table 4-1 } \\
& \text { DCRT 244-BX - See Table 4-2 } \\
& \text { DCRT 244-S }- \text { See Table 4-3 } \\
& \text { DCRT 244-TX - See Table 4-4 } \\
& \text { DCRT 244-U }- \text { See Table 4-5 }
\end{aligned}
$$

Note: Several of the thoughts for or against the different possible control decisions in Tables 4-1 to 4-5 changed subsequent to the November 16,17, and 18, 1999 control decision meetings. The major change is based on the final predictions of DCRT flammable gas concentrations in RPP-4941, Methodology for Predicting Flammable Gas 
Mixtures in Double-Contained Receiver Tanks (CHG 2000c). These predictions showed that except for new salt well waste transfers to DCRT 244-S from 241-S and 241-SX tank farms, the DCRT ventilation systems can maintain the flammable gas concentration (hydrogen, ammonia, and methane) below $25 \%$ of the LFL during waste storage and waste transfers (see Tables 4-6 and 4-7). Also subsequent to the November 1999 control decision meetings, salt well pumping of Tank 241-T-110 was completed.

At the April 19, 2000 control decision meeting, controls were identified to address flammable gas hazards in a DCRT vault caused by the receiver tank failure. Based on the analysis in RPP-4941, this hazard only exists for DCRT 244-S if new salt well waste is transferred from 241-S or 241-SX tank farms and for 244-CR Vault Tank 003 if material is transferred to the tank (see Table 4-8). At the April 19, 2000 meeting possible controls for DCRT 244-S considered to address this hazard and thoughts for and against the controls are presented below. (Note: Although possible controls for 244-CR Vault Tank 003 were not specifically considered, the possible controls identified below for DCRT 244-S are also applicable to 244-CR Vault Tank 003.)

DCRT vault leak detection system (i.e., vault sump level detection system) - Although this system exists, this control would require its designation as a safety-significant SSC and a new TSR would be required to ensure its operability.

DCRT level detection system - This system is already designated as a safety-significant SSC, but a new TSR would be required to ensure its operability and/or periodically monitor the tank level for unexpected decreases.

DCRT exhaust ventilation continuous air monitor (CAM) - This CAM is already designated as a safety-class SSC, but there are several ongoing activities to eliminate the safety SSC designation. A new or revised TSR would be required to ensure its operability for purposes of vault waste leak detection.

DCRT vault temperature monitoring - This system does not currently exist, but was identified as a possibly more reliable method of detecting waste leaks into the DCRT vault. This possible control would require the design and installation of this safety-significant SSC and a new TSR to ensure its operability and/or periodically monitor the vault temperature for unexpected increases. An engineering basis would also have to be developed to demonstrate the effectiveness and application of this leak detection method, which would be new in the Authorization Basis.

The analysis of flammable gas hazards for 244-CR Vault Tank 003 shows that there is no hazard for the existing waste in the tank. At the April 19, 2000 control decision meeting possible control decisions identified and thoughts for and against the controls are presented below.

Maintain existing controls (i.e., active safety-significant ventilation system and LCO 3.2.4 control to ensure its operability, and existing AC 5.10 and 5.11 flammable gas ignition and monitoring controls) - According to RPP-4941 predictions, operation of the 244-CR Vault ventilation system is not required. Continuation of flammable gas ignition and monitoring controls is prudent. 
Maintain existing AC 5.10 and 5.11 flammable gas ignition and monitoring controls, but eliminate the LCO 3.2.4 requirement for operation of the 244-CR Vault ventilation system - RPP-4941 supports this control decision.

Same as above, but add a new TSR requirement for periodic monitoring of 244-CR Vault Tank 003 (e.g., once every 31 days) - The new monitoring requirement would address any questions and uncertainties that may exist with the RPP-4941 analysis. 
RPP-5554 REV 0

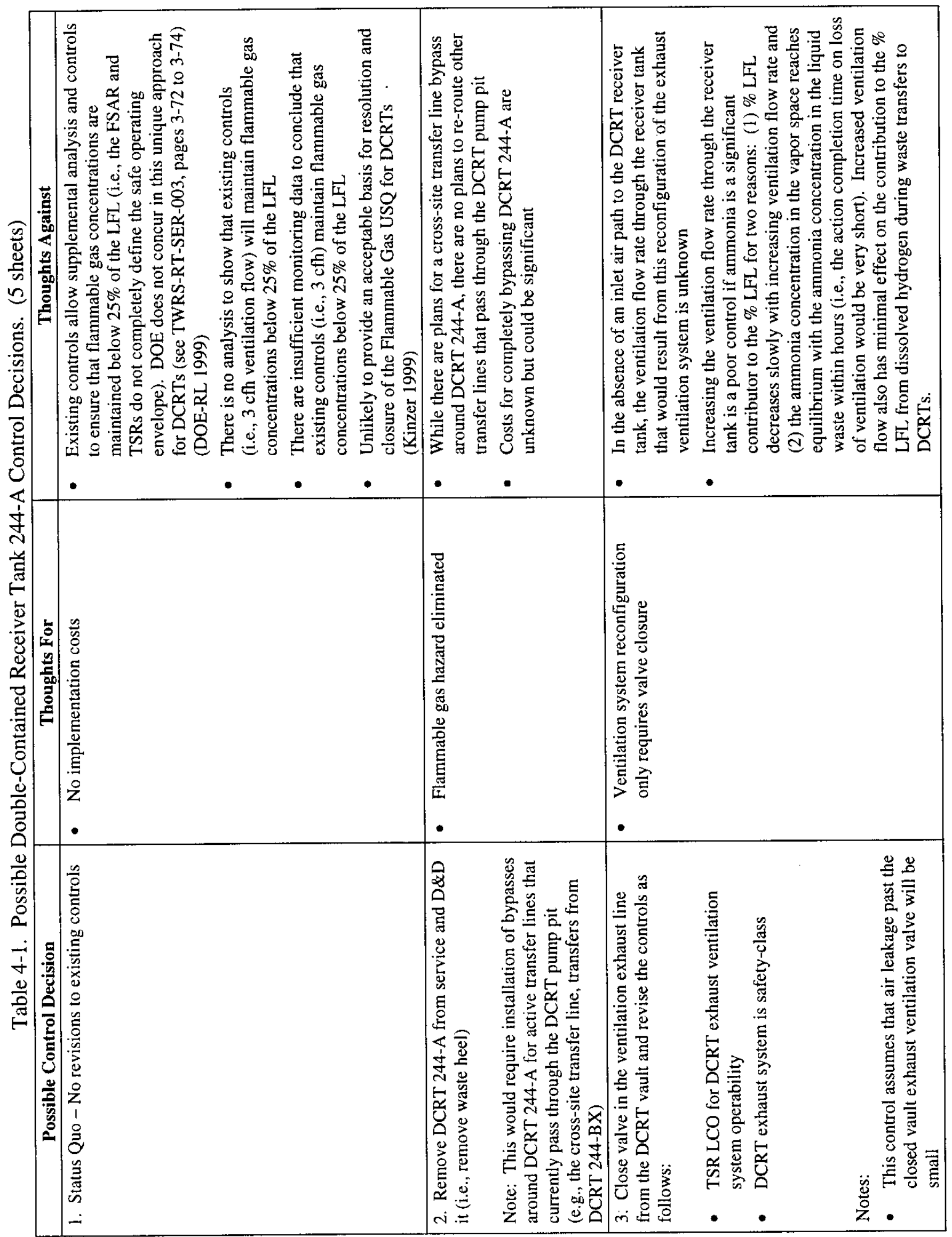




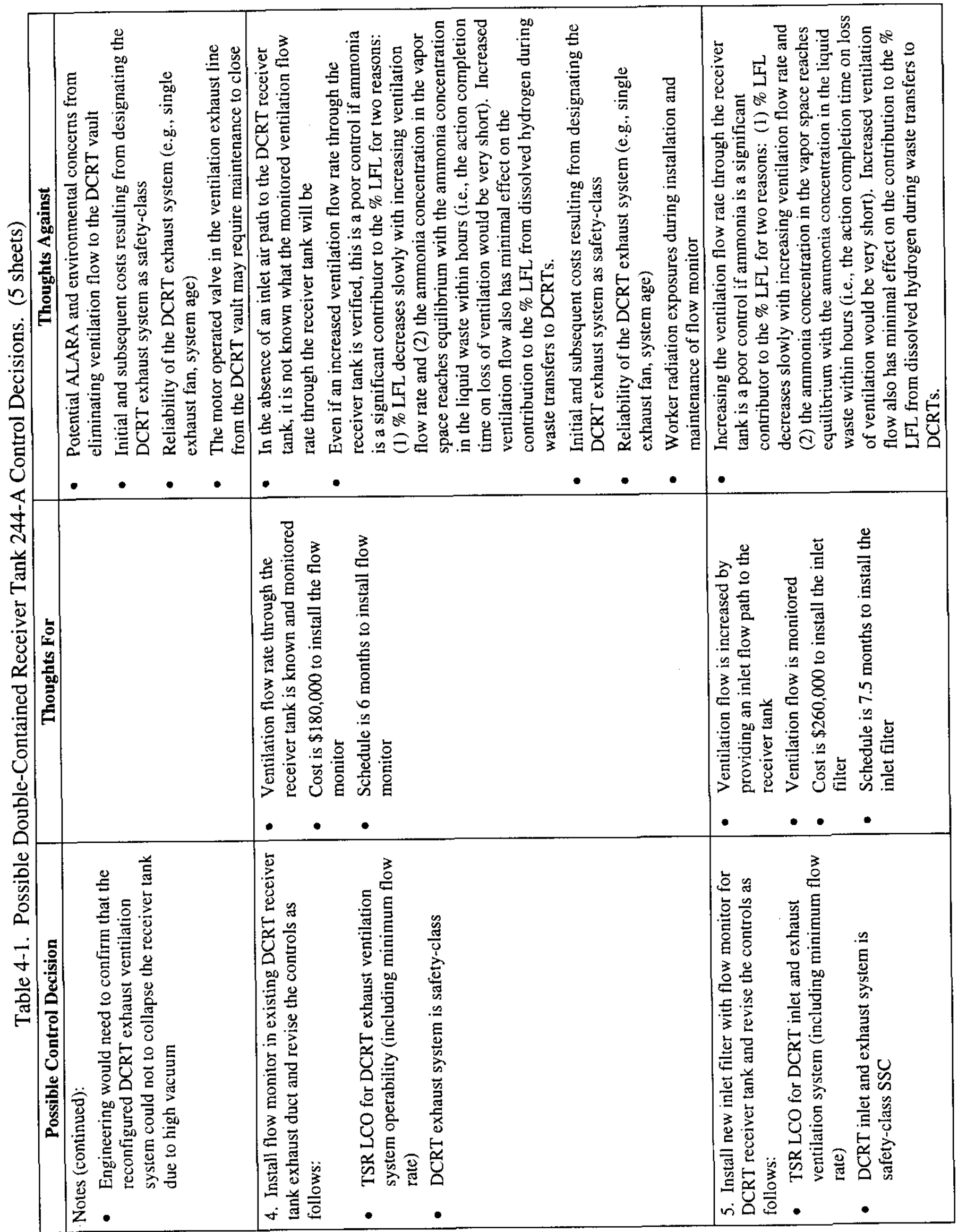




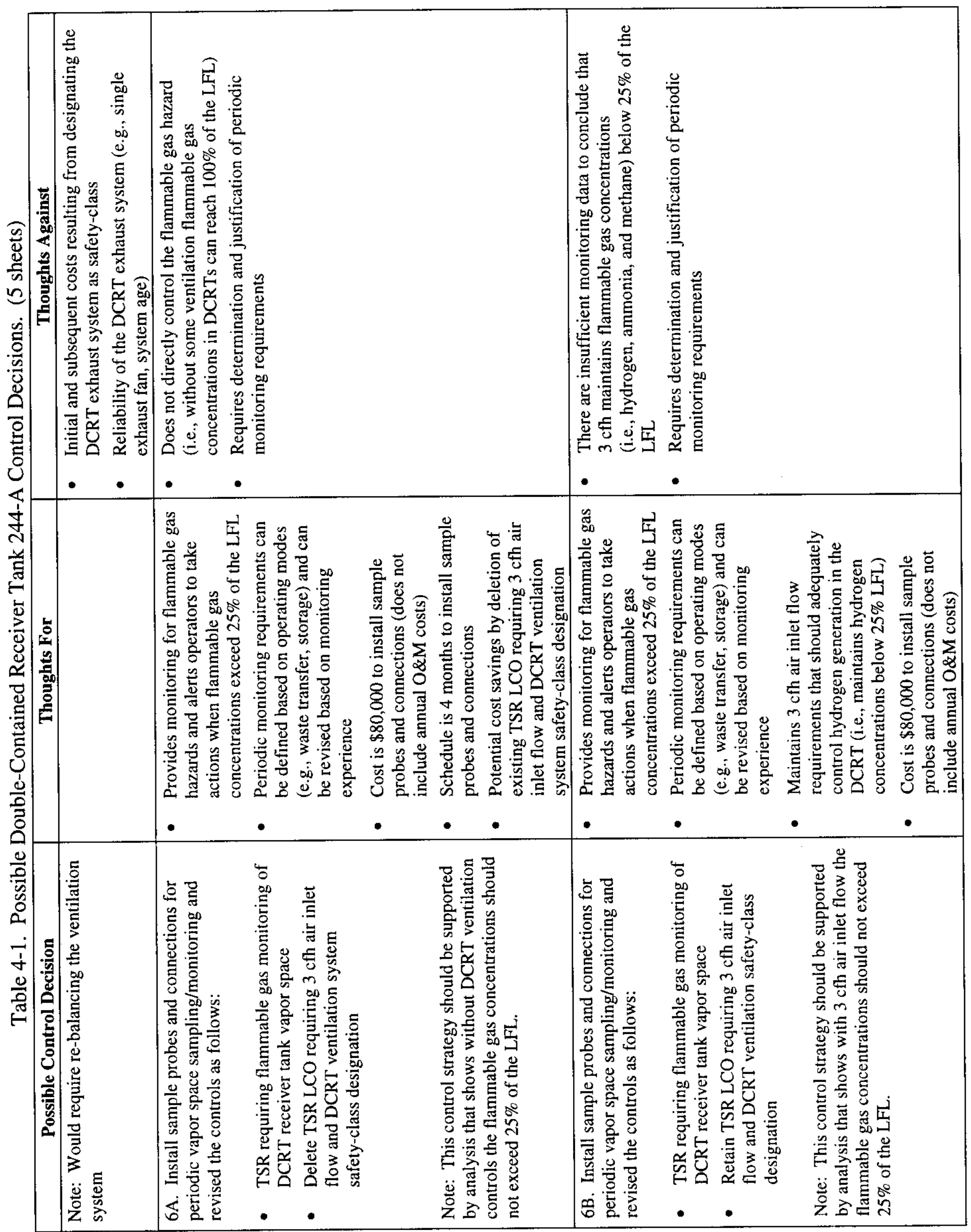




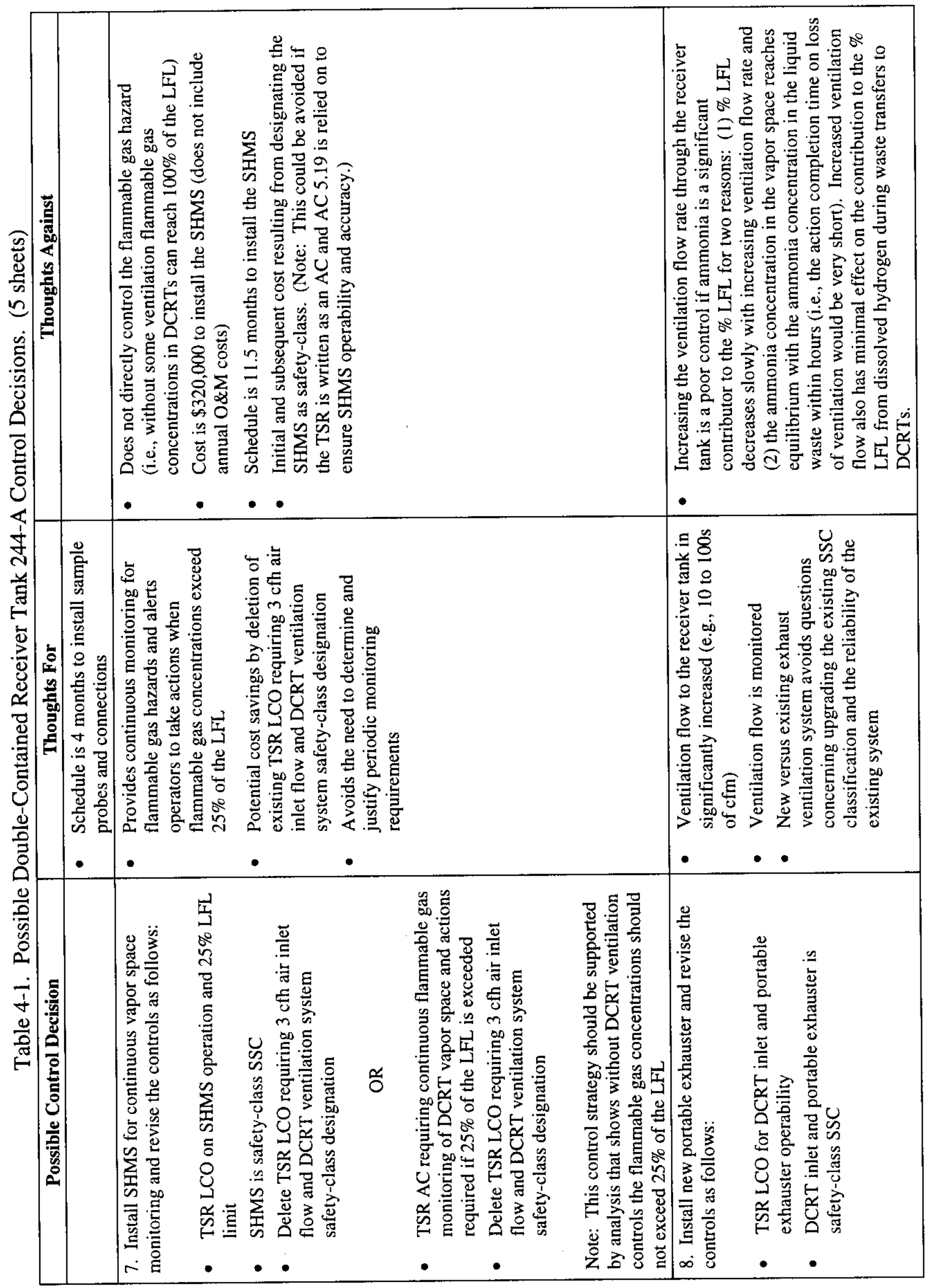


RPP-5554 REV 0

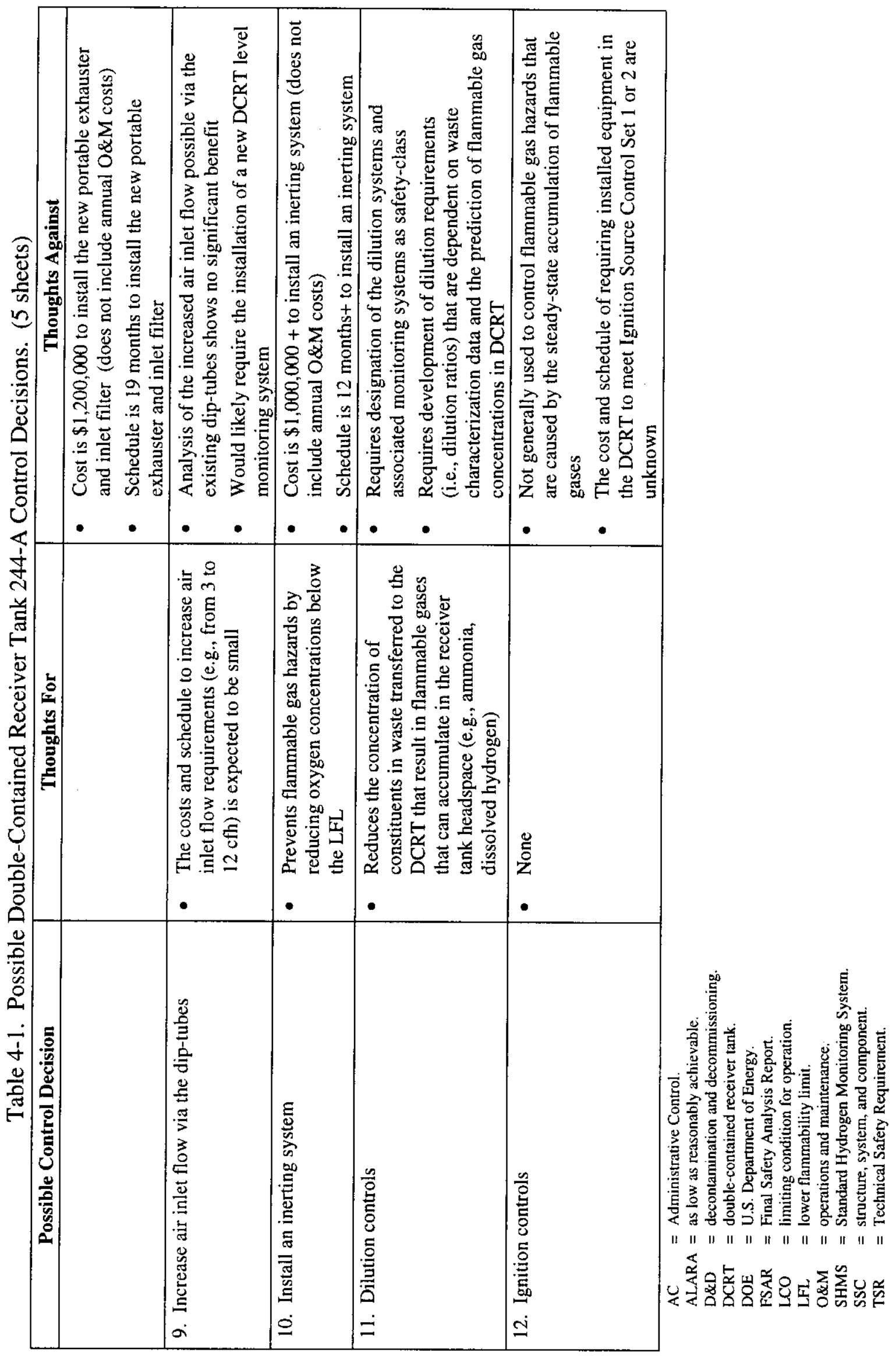


RPP-5554 REV 0

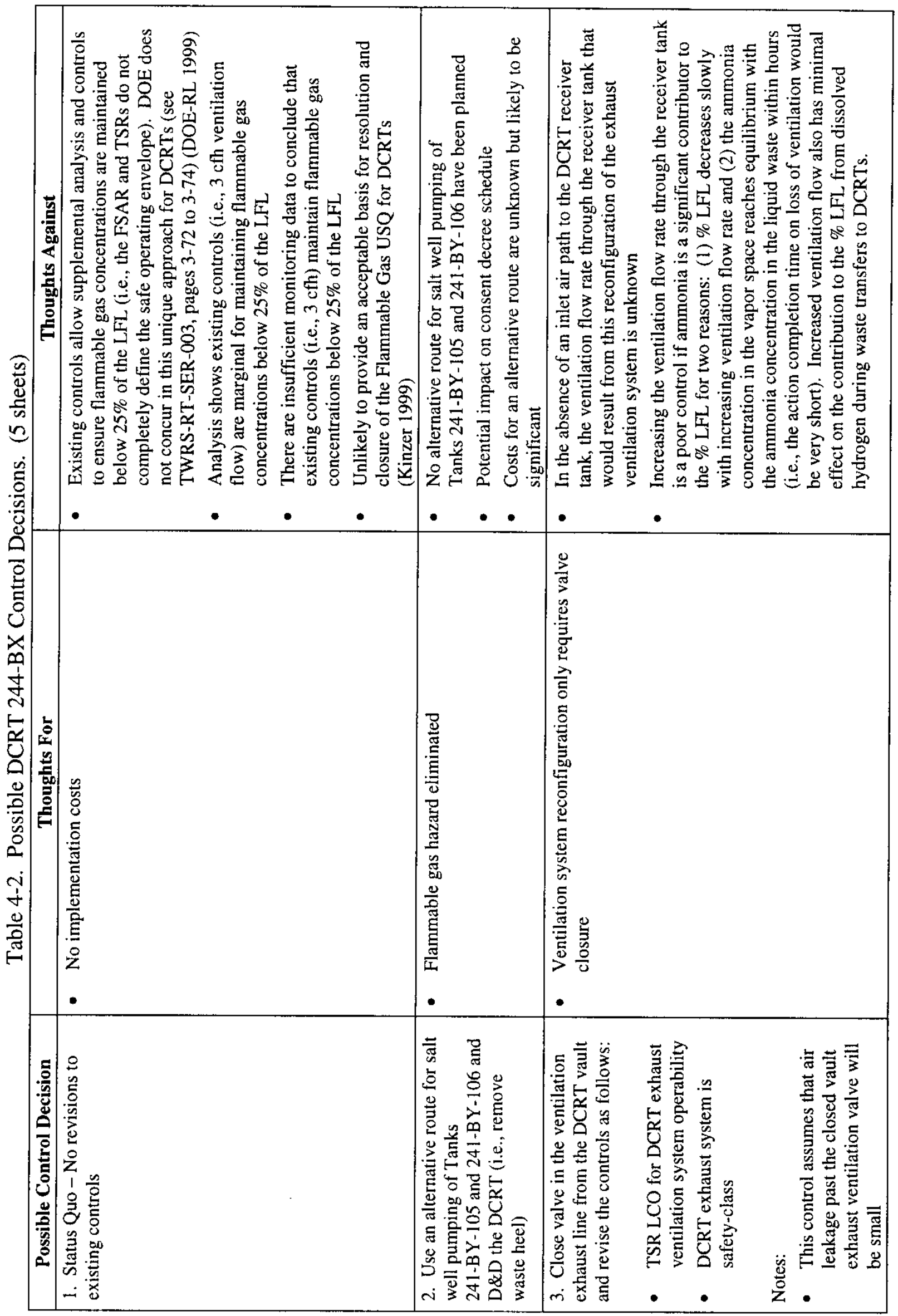




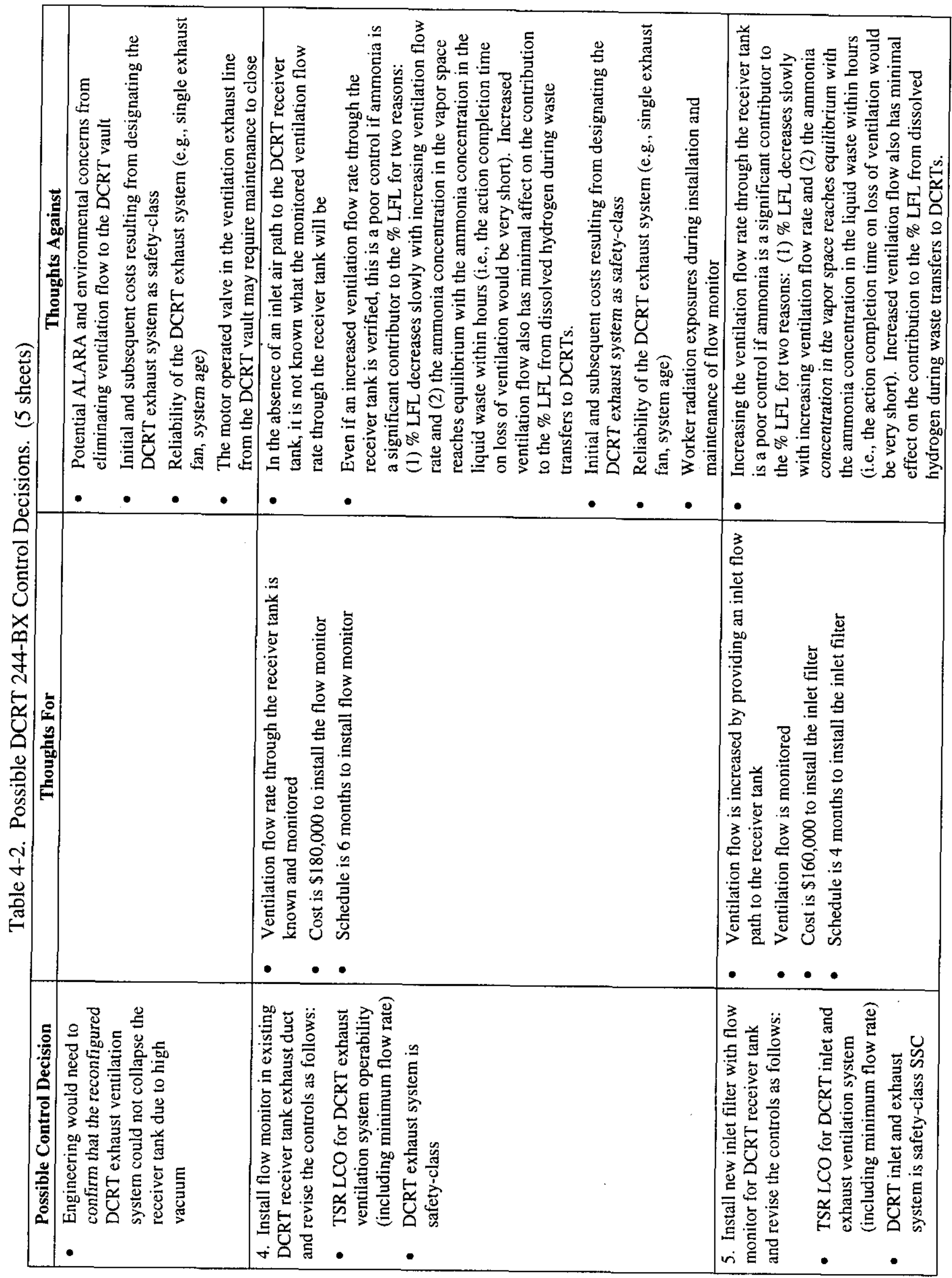


RPP-5554 REV 0

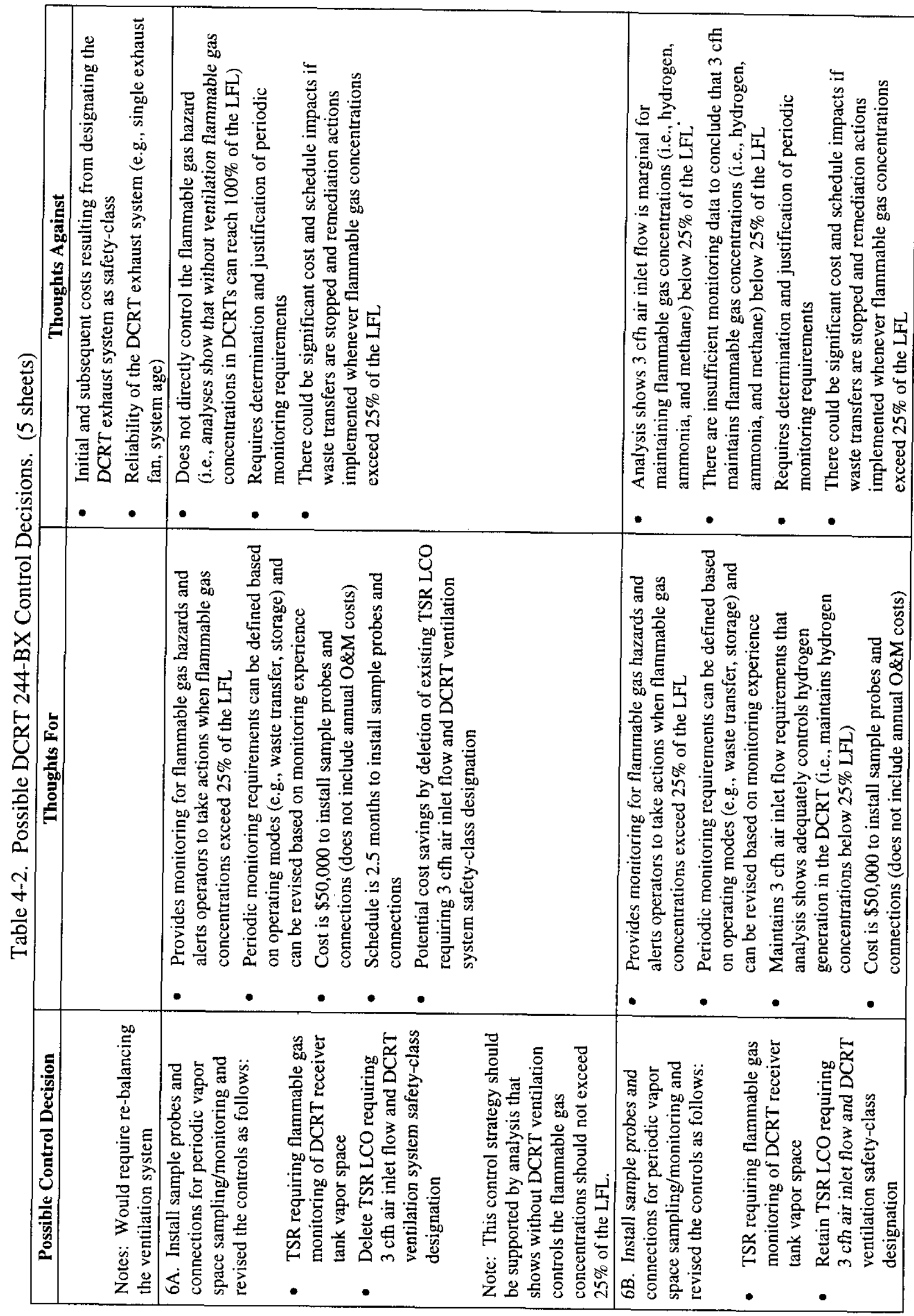




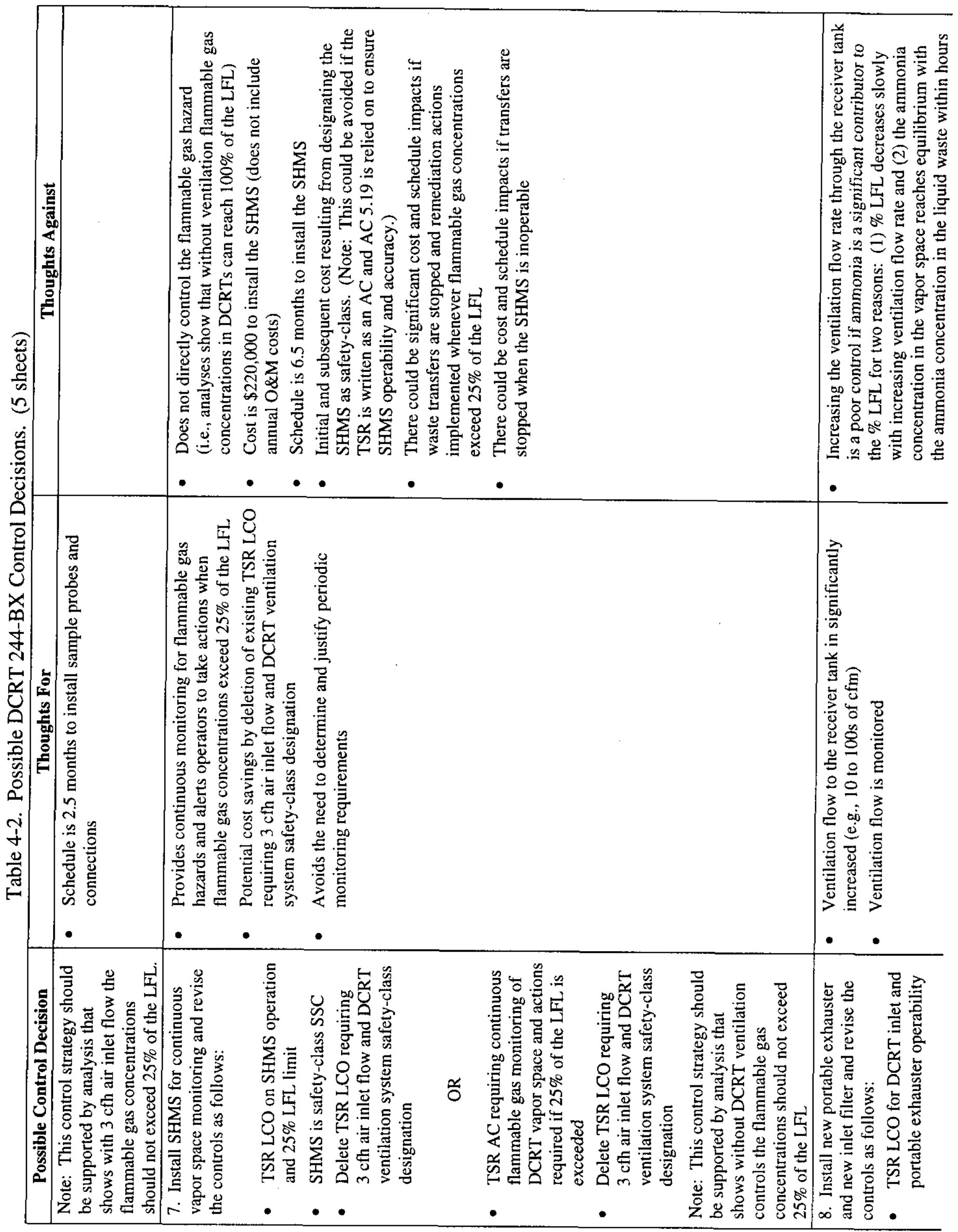


RPP-5554 REV 0

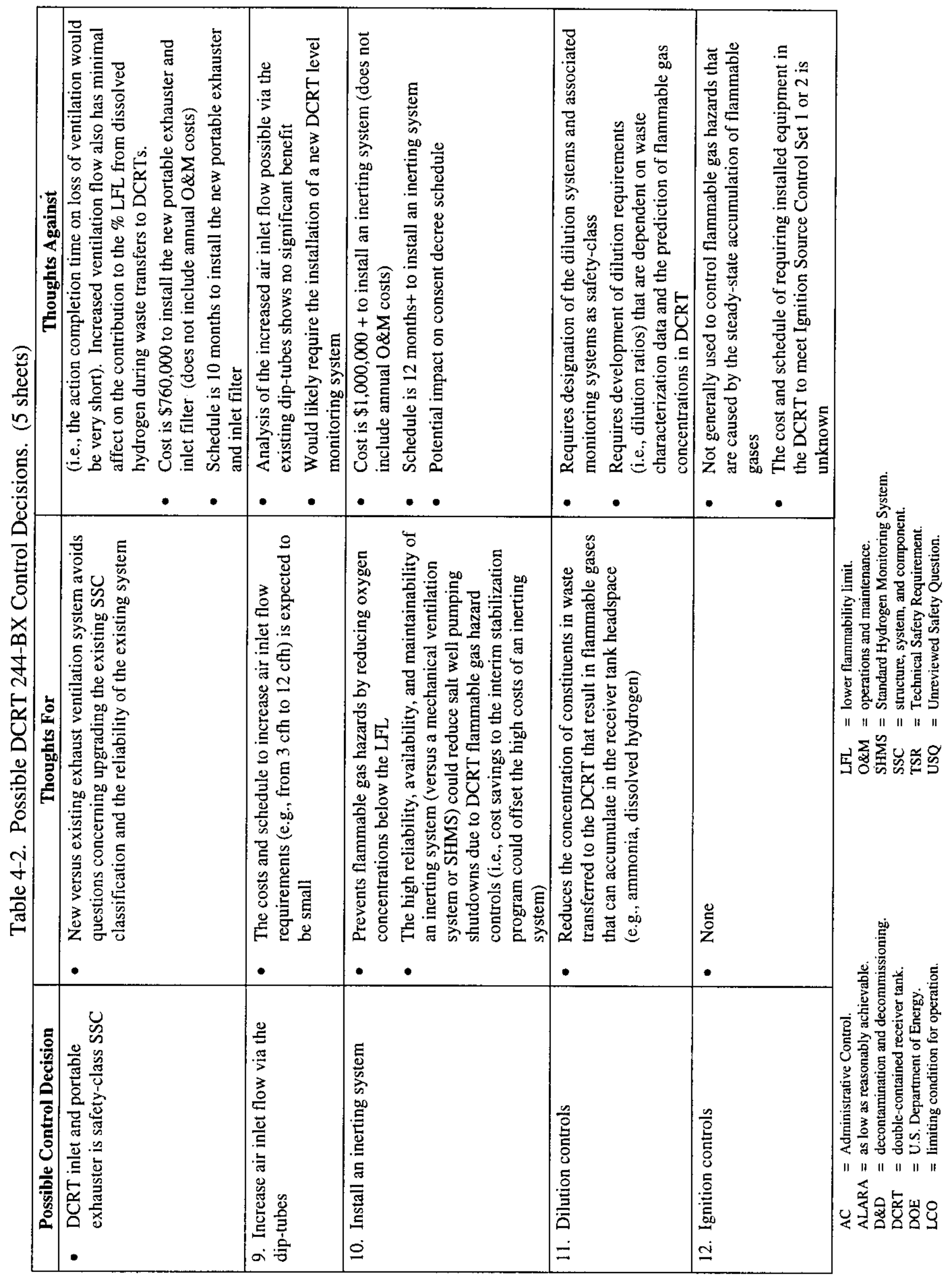


RPP-5554 REV 0

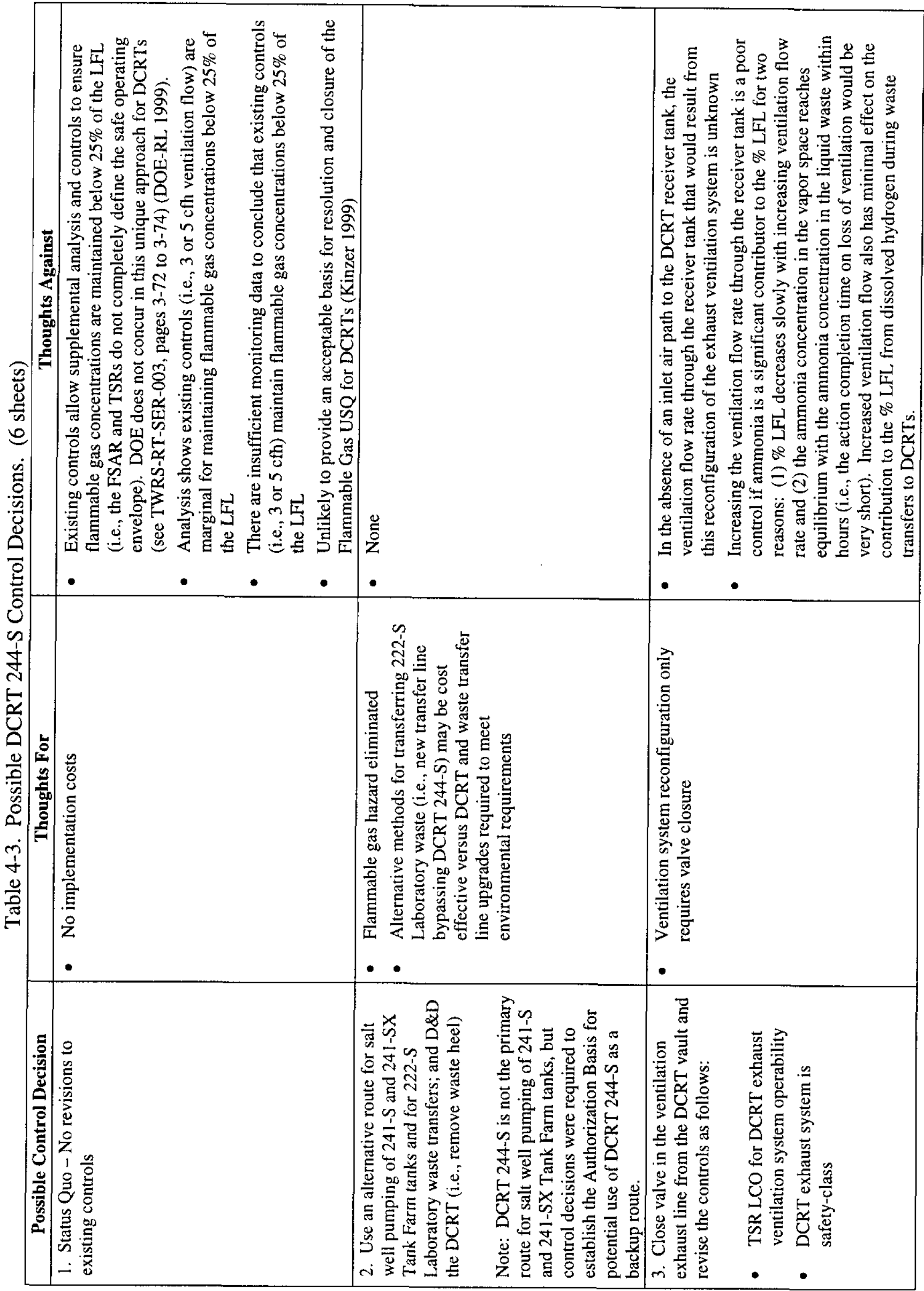




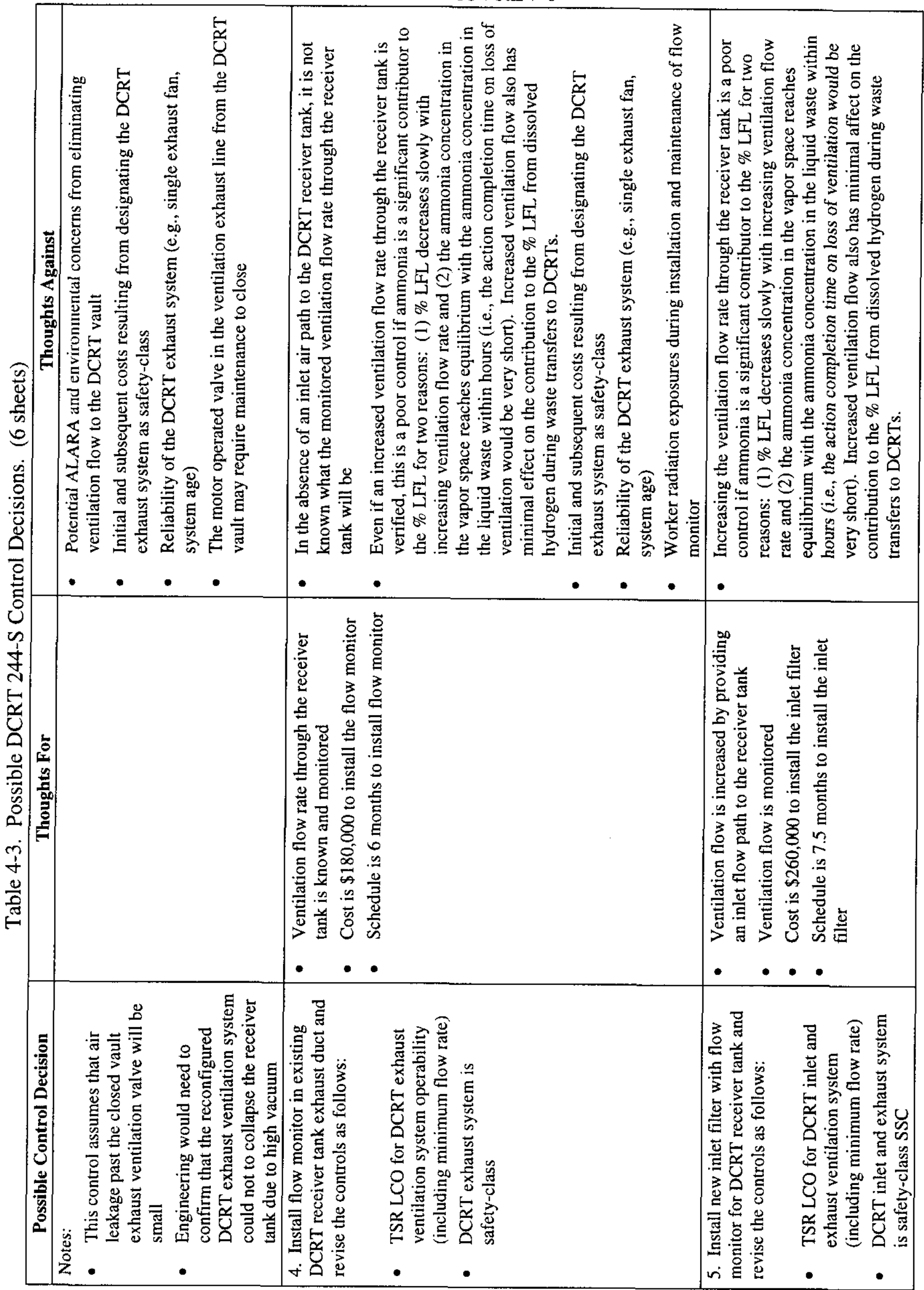




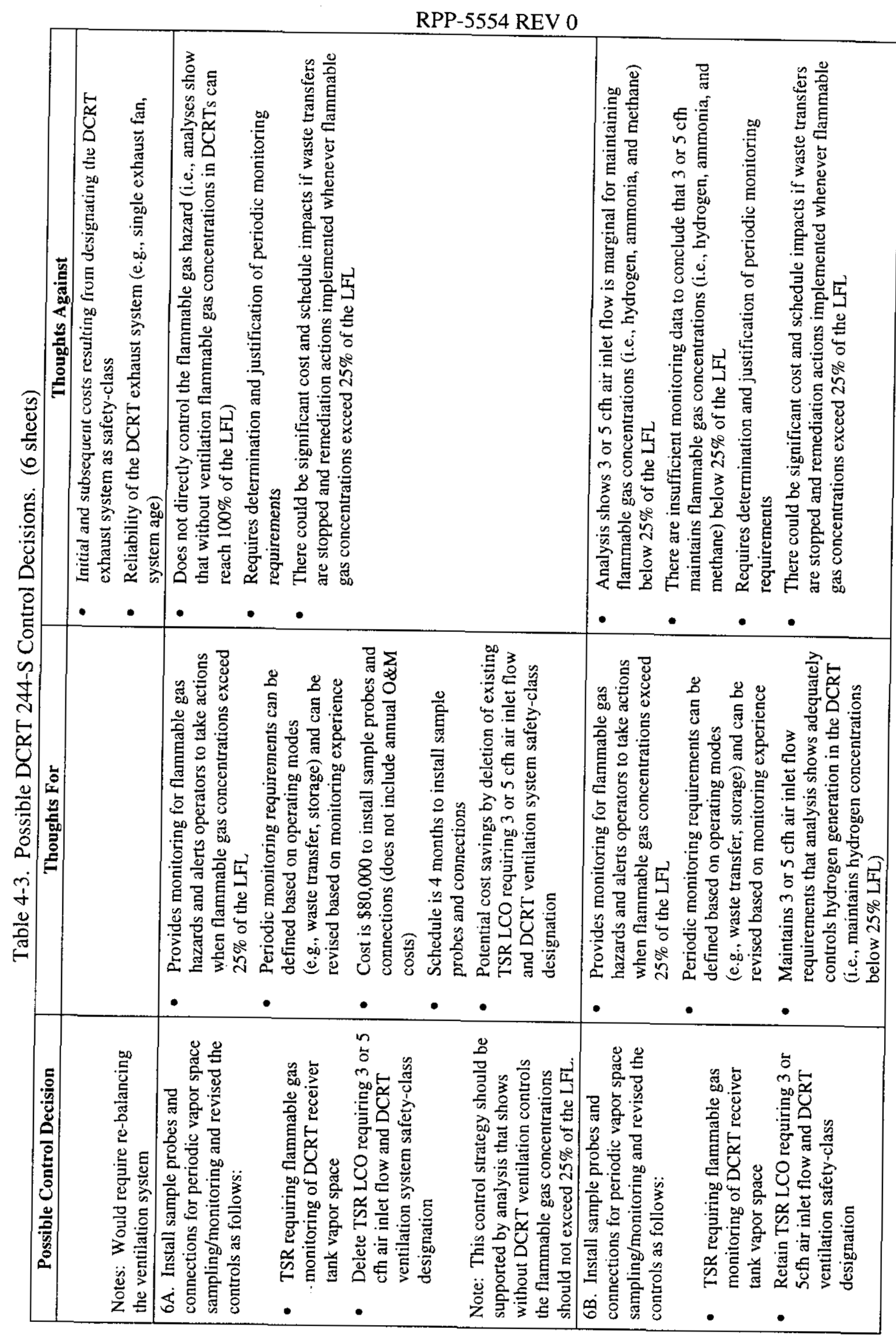




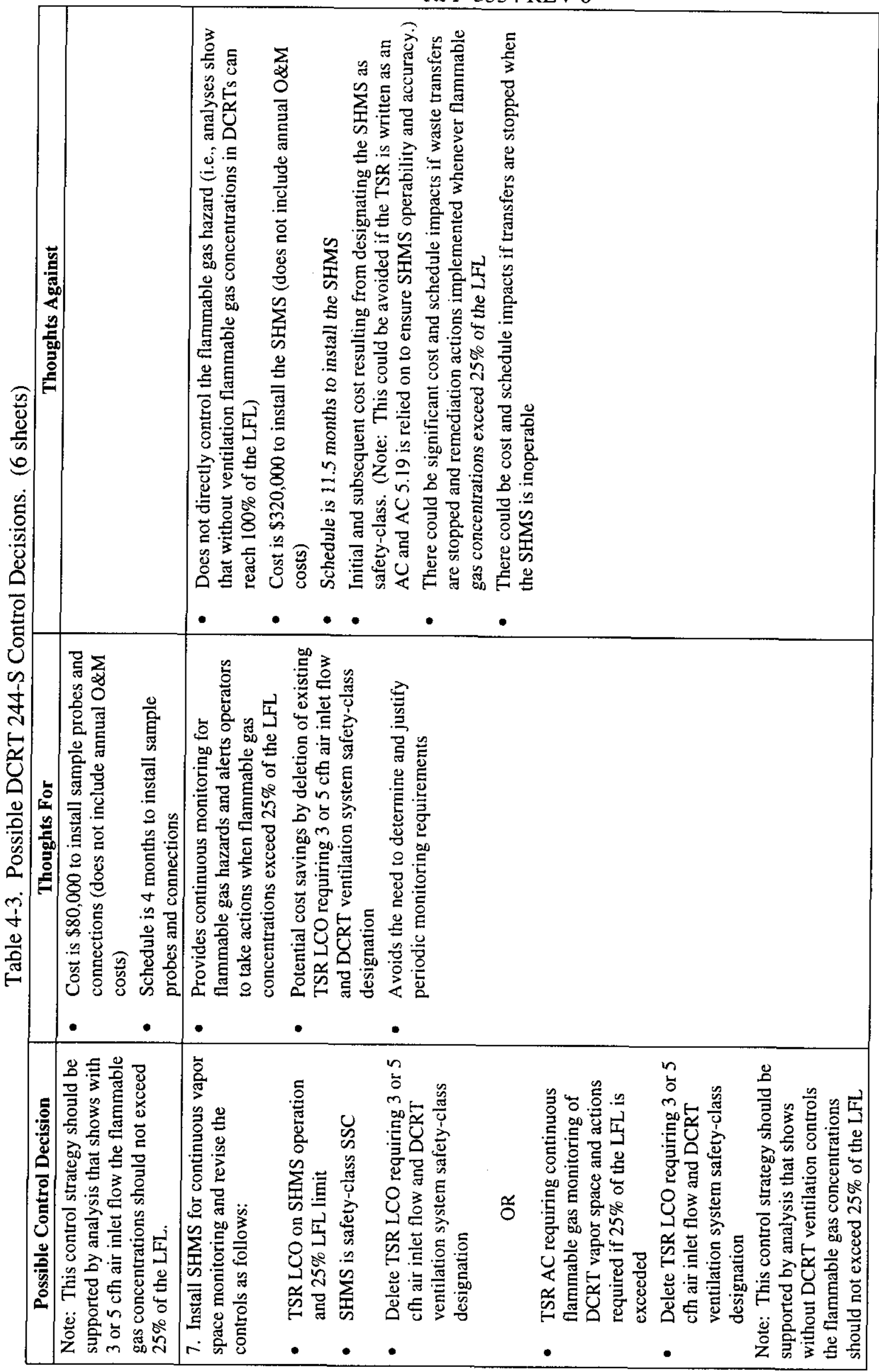


RPP-5554 REV 0

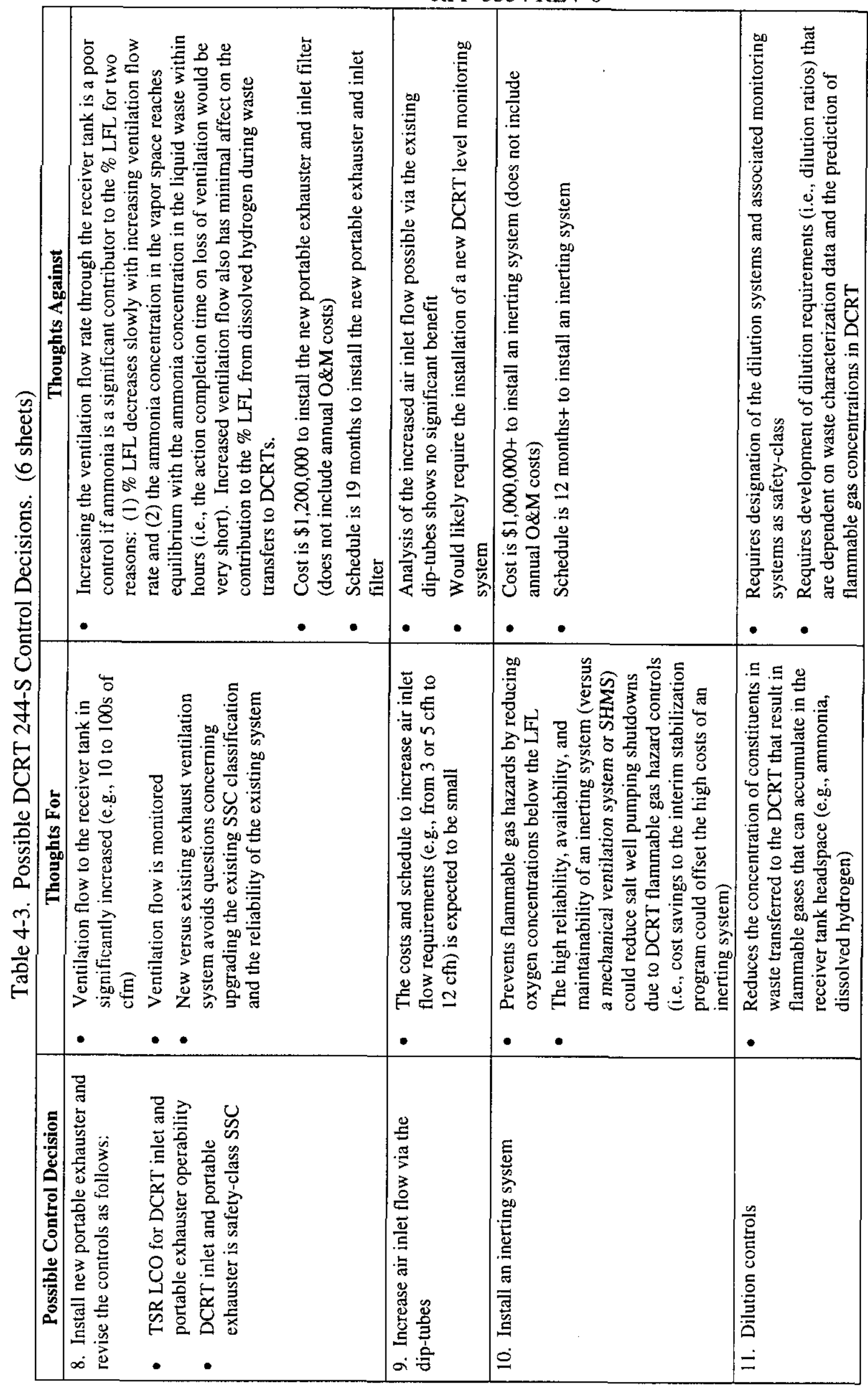


RPP-5554 REV 0

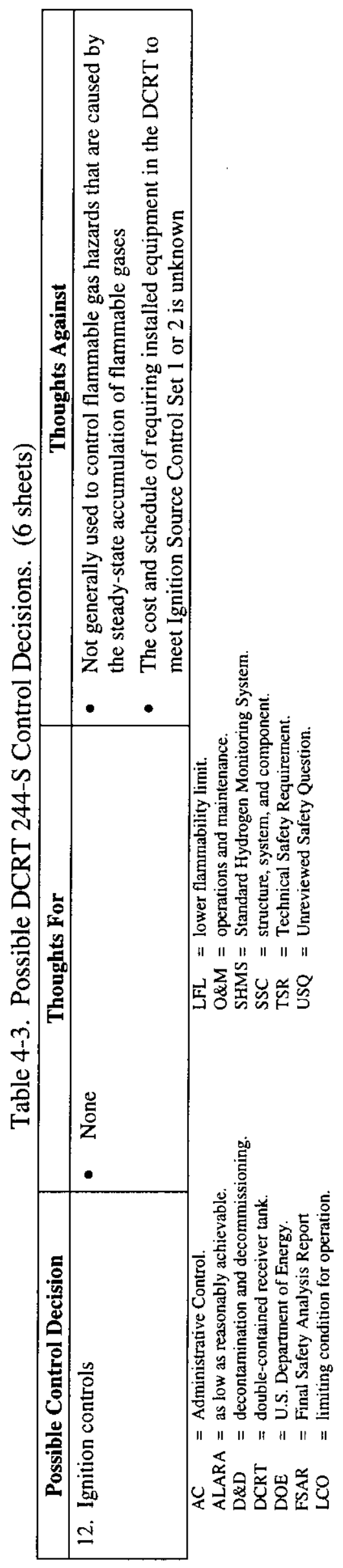


RPP-5554 REV 0

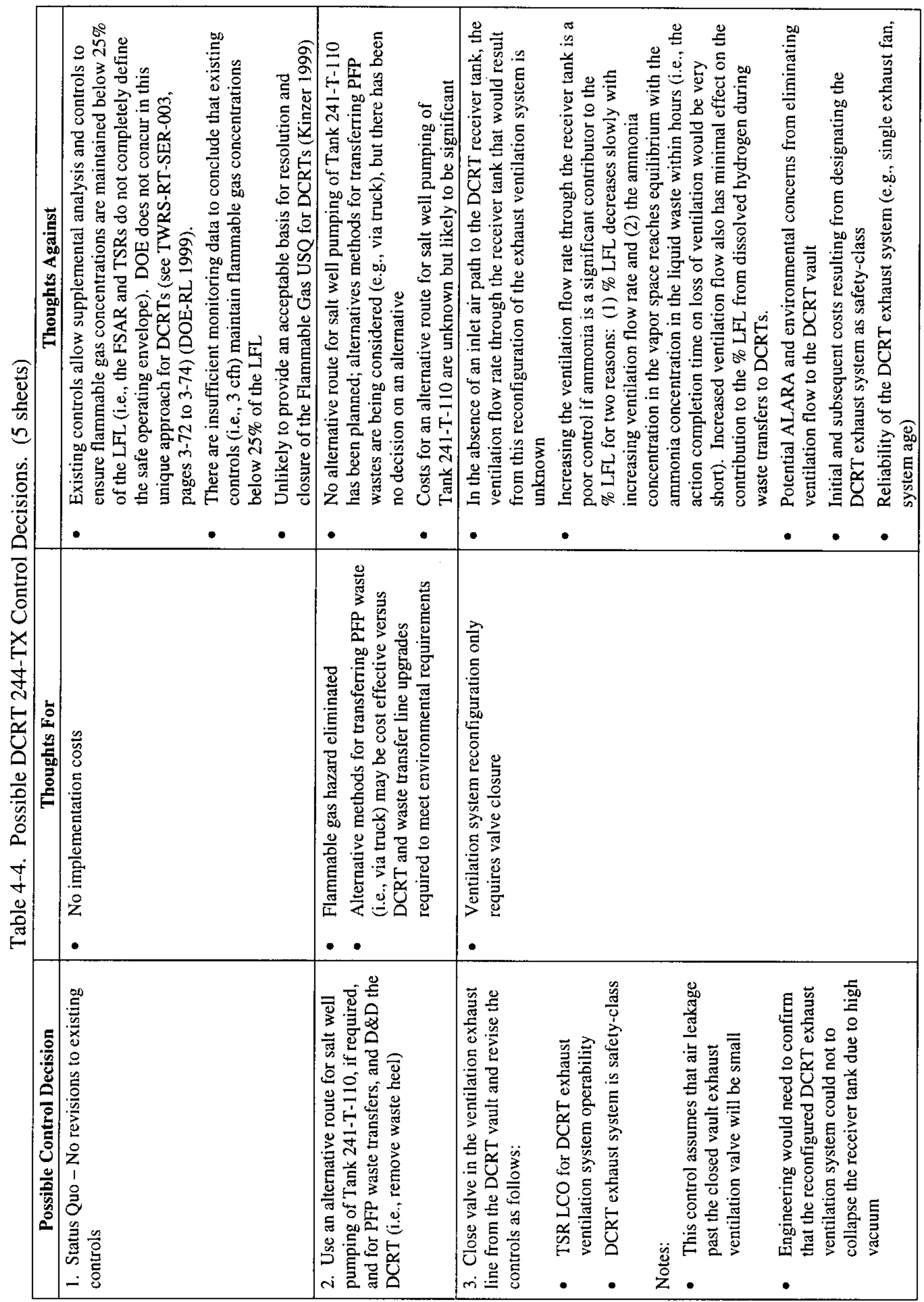


RPP-5554 REV 0

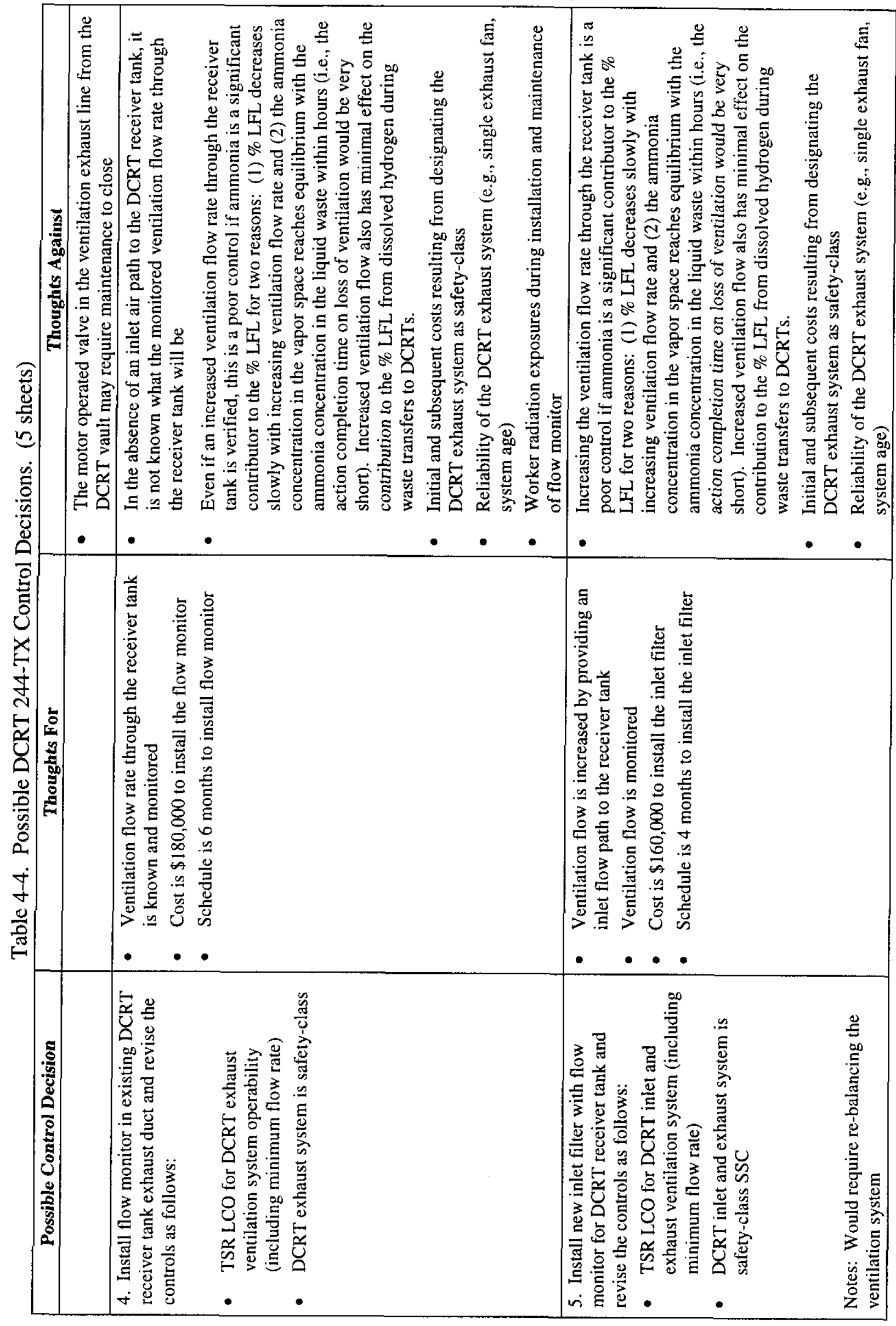




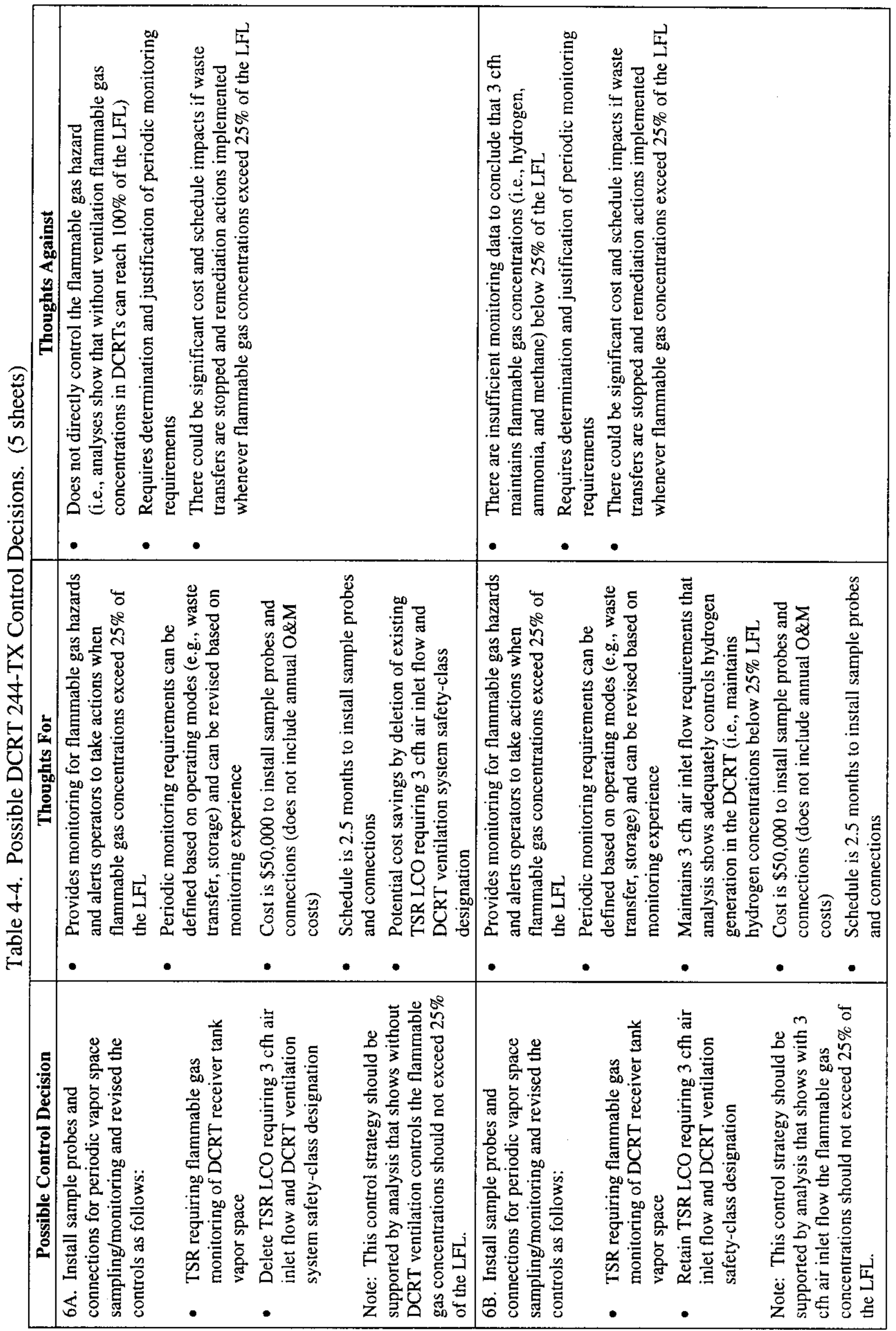




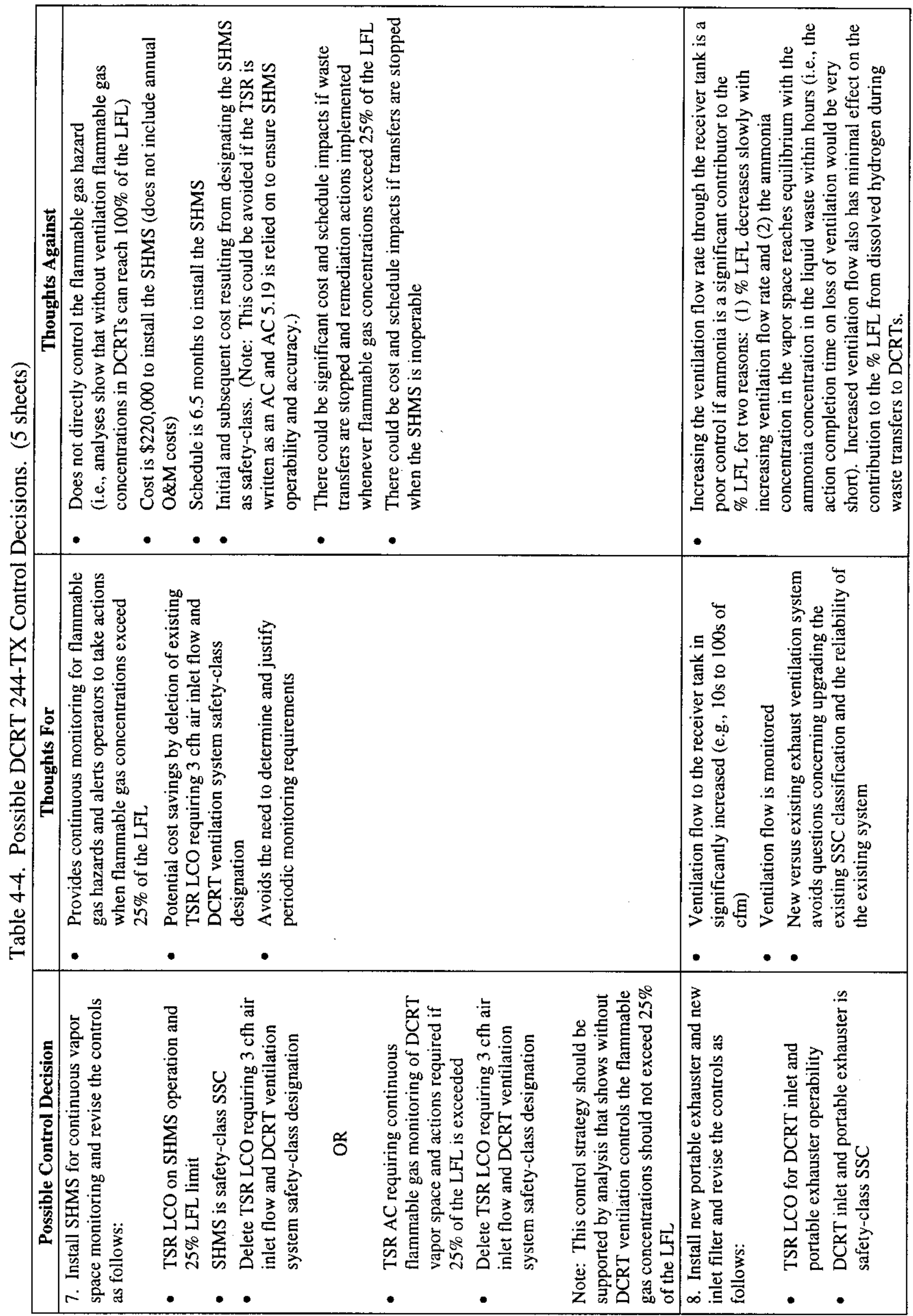




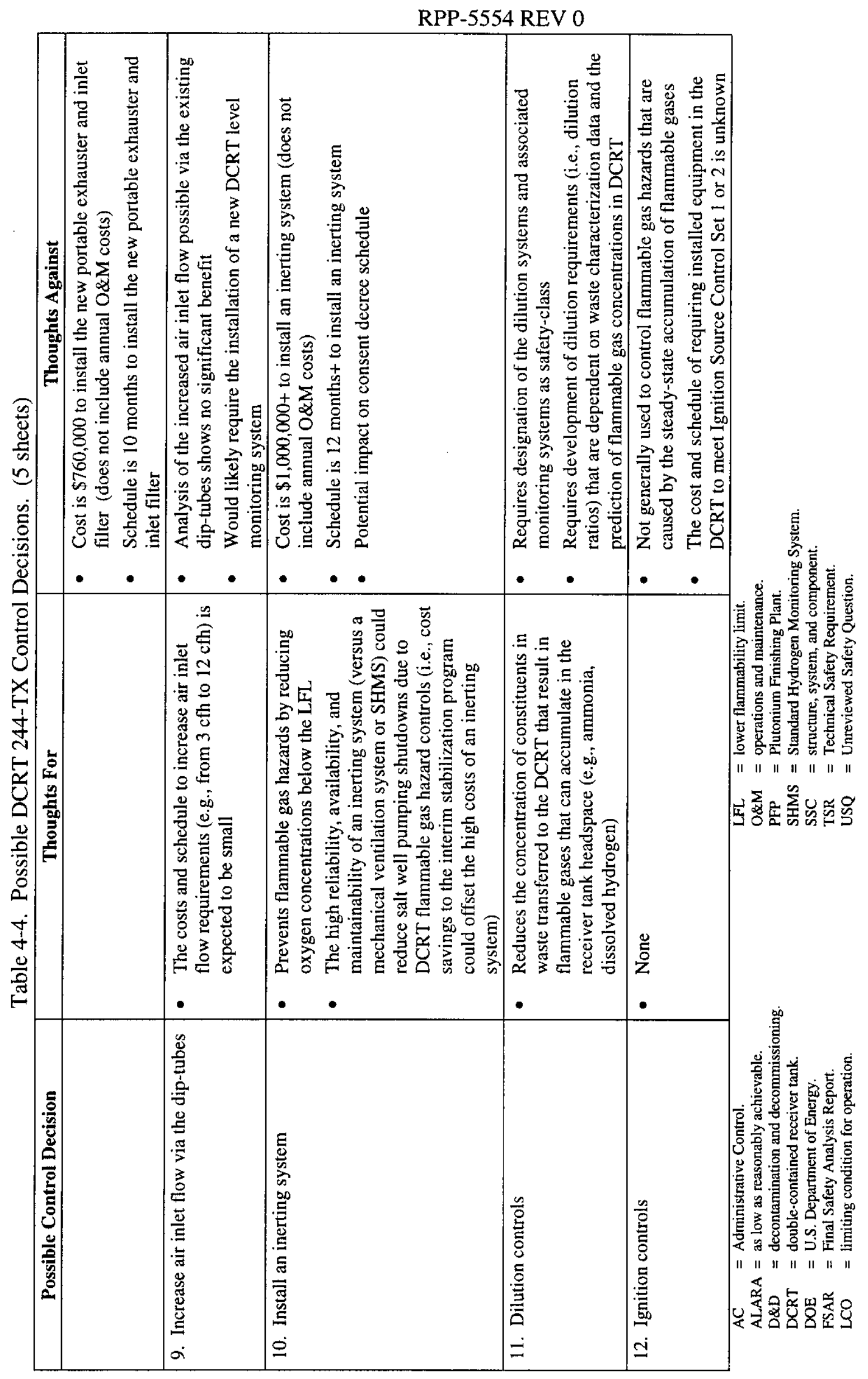


RPP-5554 REV 0

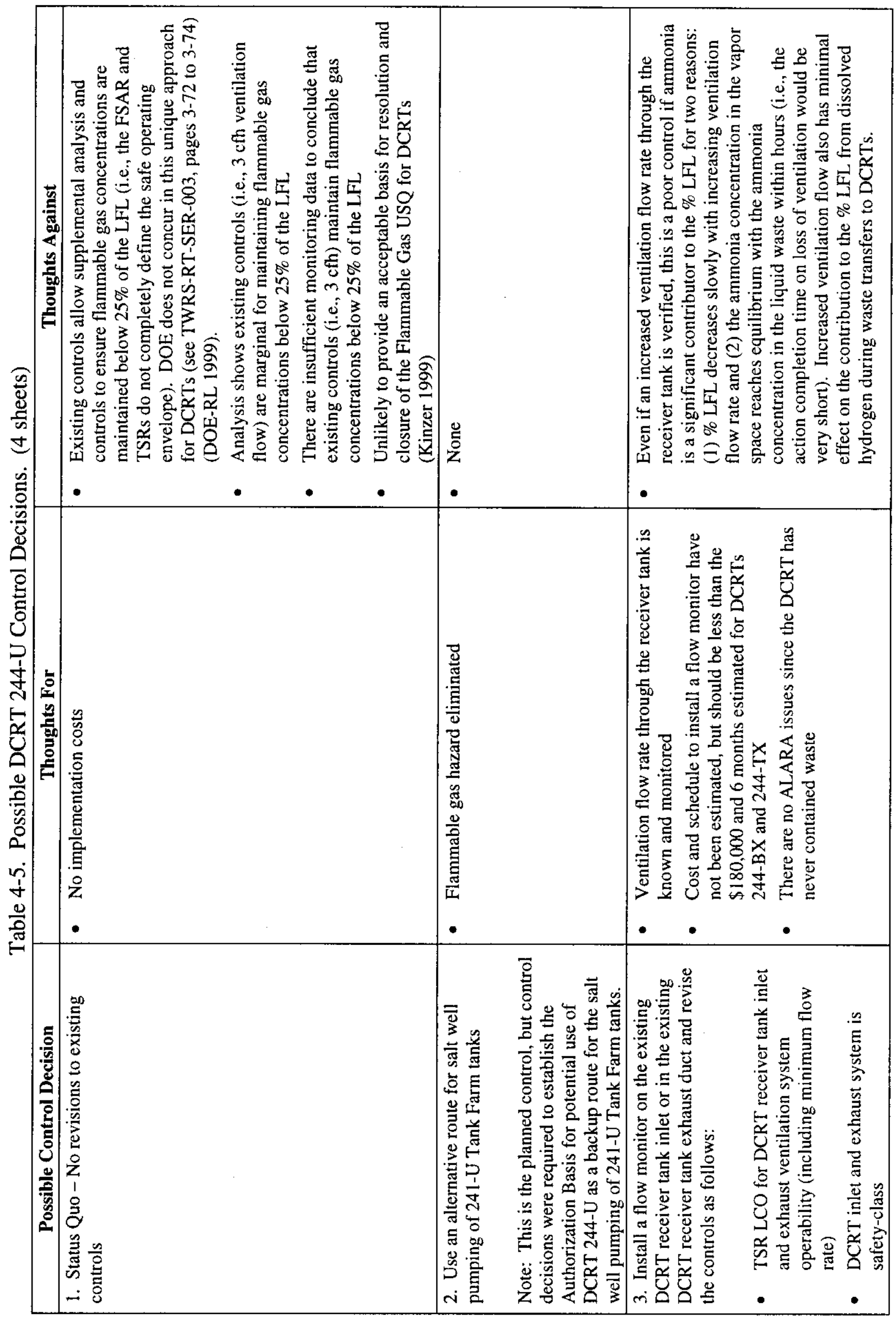


RPP-5554 REV 0

\begin{tabular}{|c|c|c|c|c|c|c|c|c|}
\hline \multirow{2}{*}{\multicolumn{2}{|c|}{ 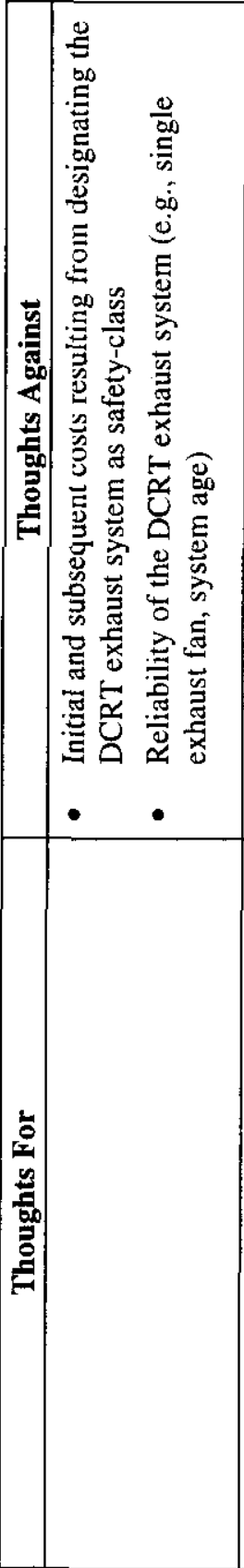 }} & \multicolumn{3}{|c|}{ 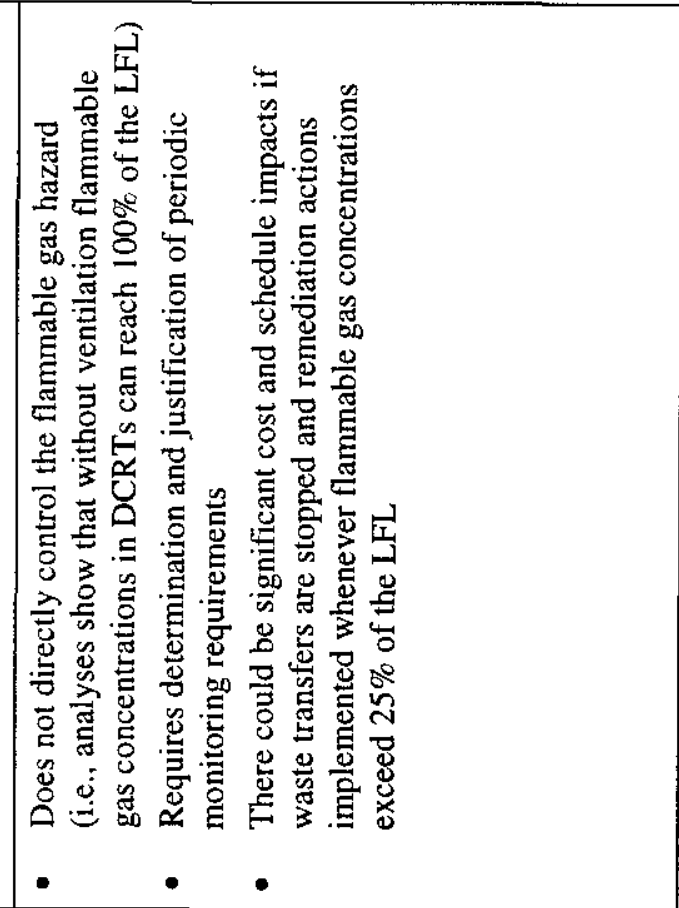 } & \multicolumn{4}{|c|}{ 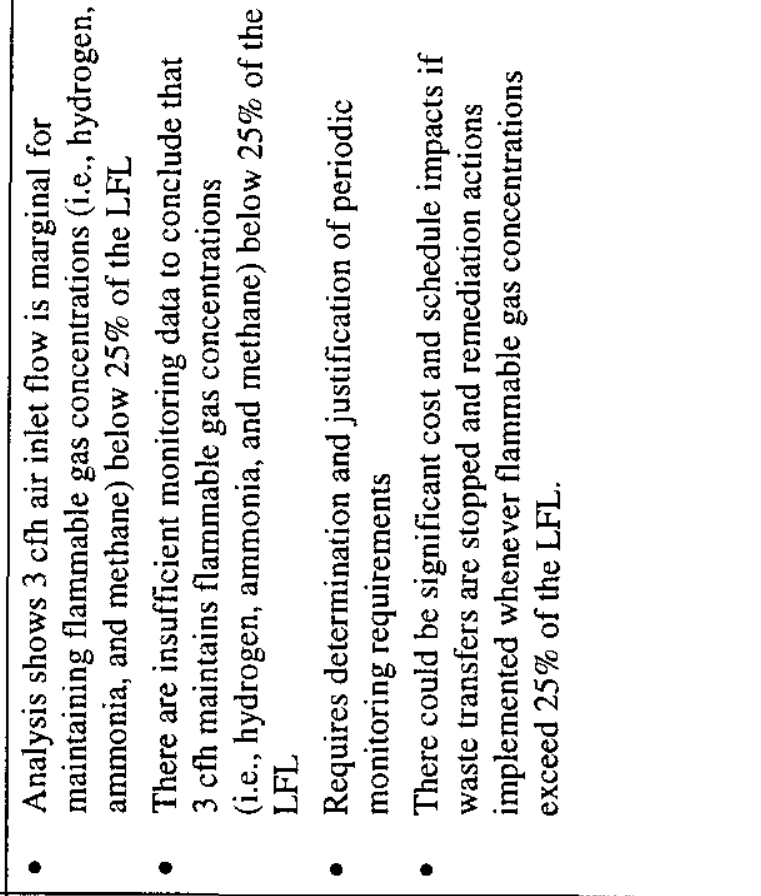 } \\
\hline & & 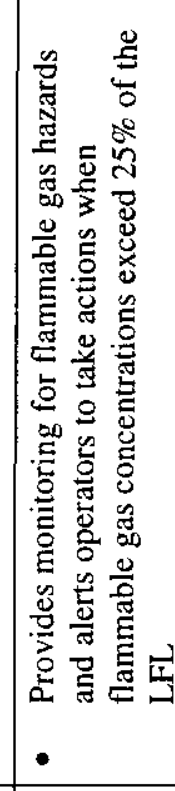 & 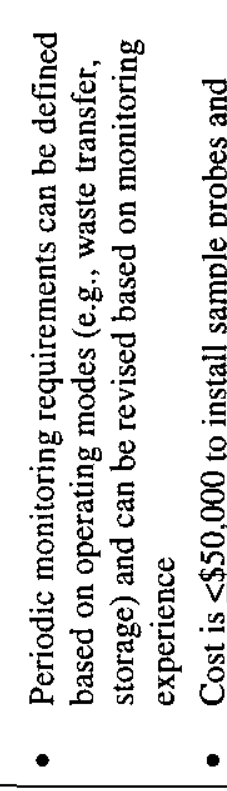 & 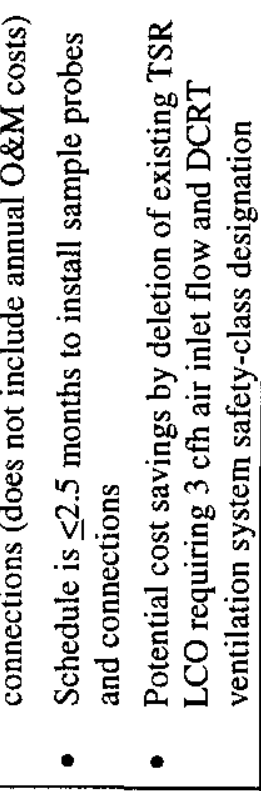 & 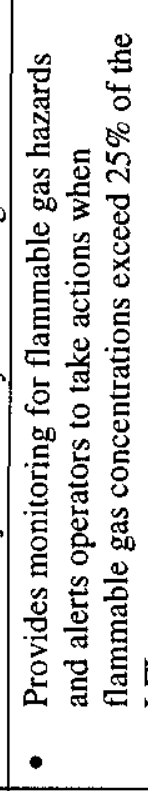 & 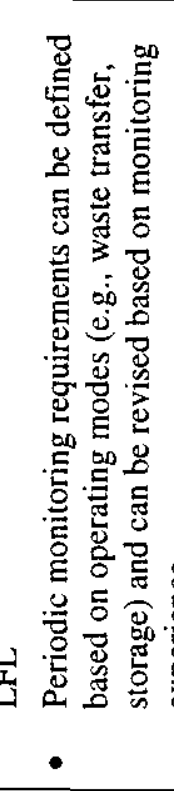 & 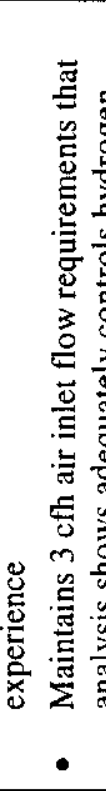 & 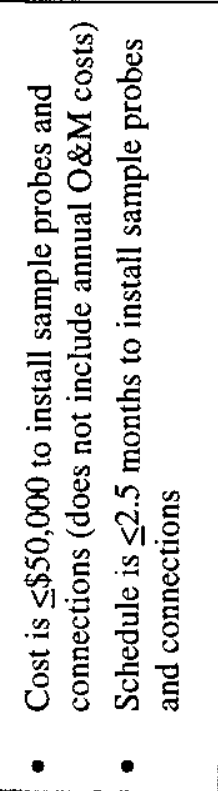 \\
\hline & 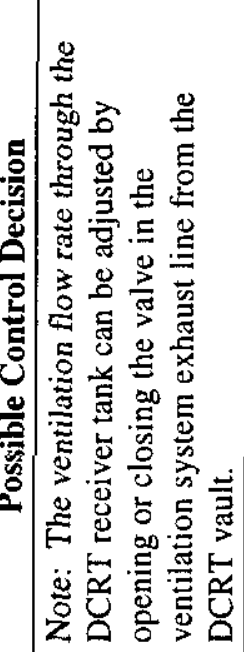 & 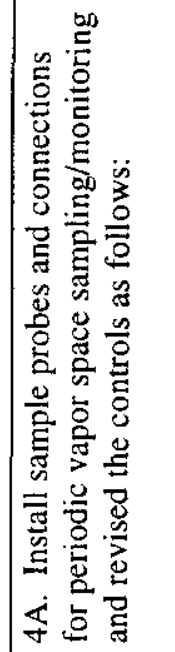 & 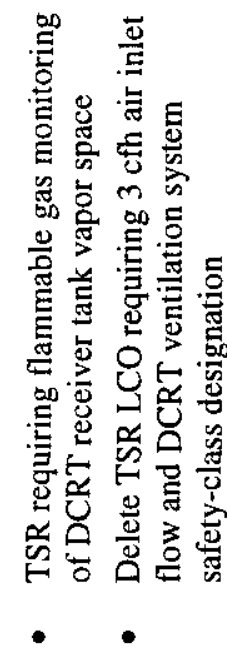 & 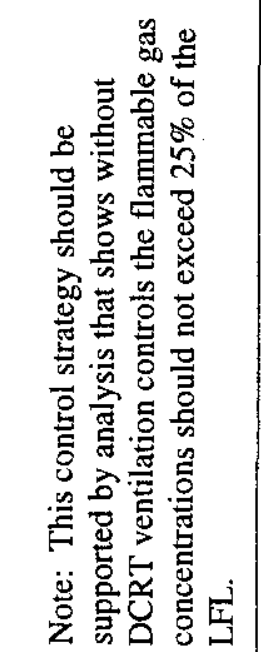 & 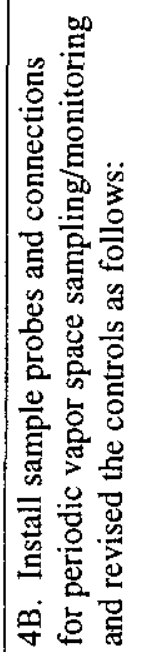 & 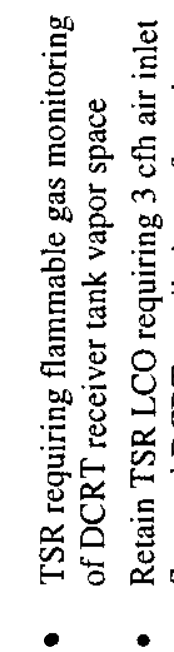 & 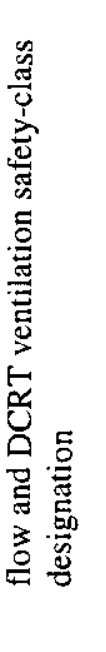 & 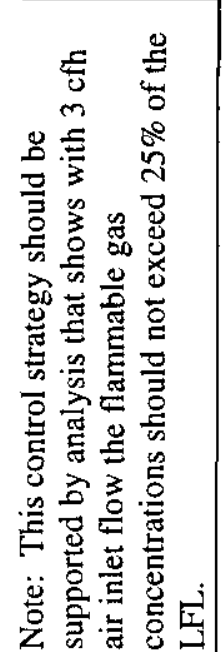 \\
\hline
\end{tabular}




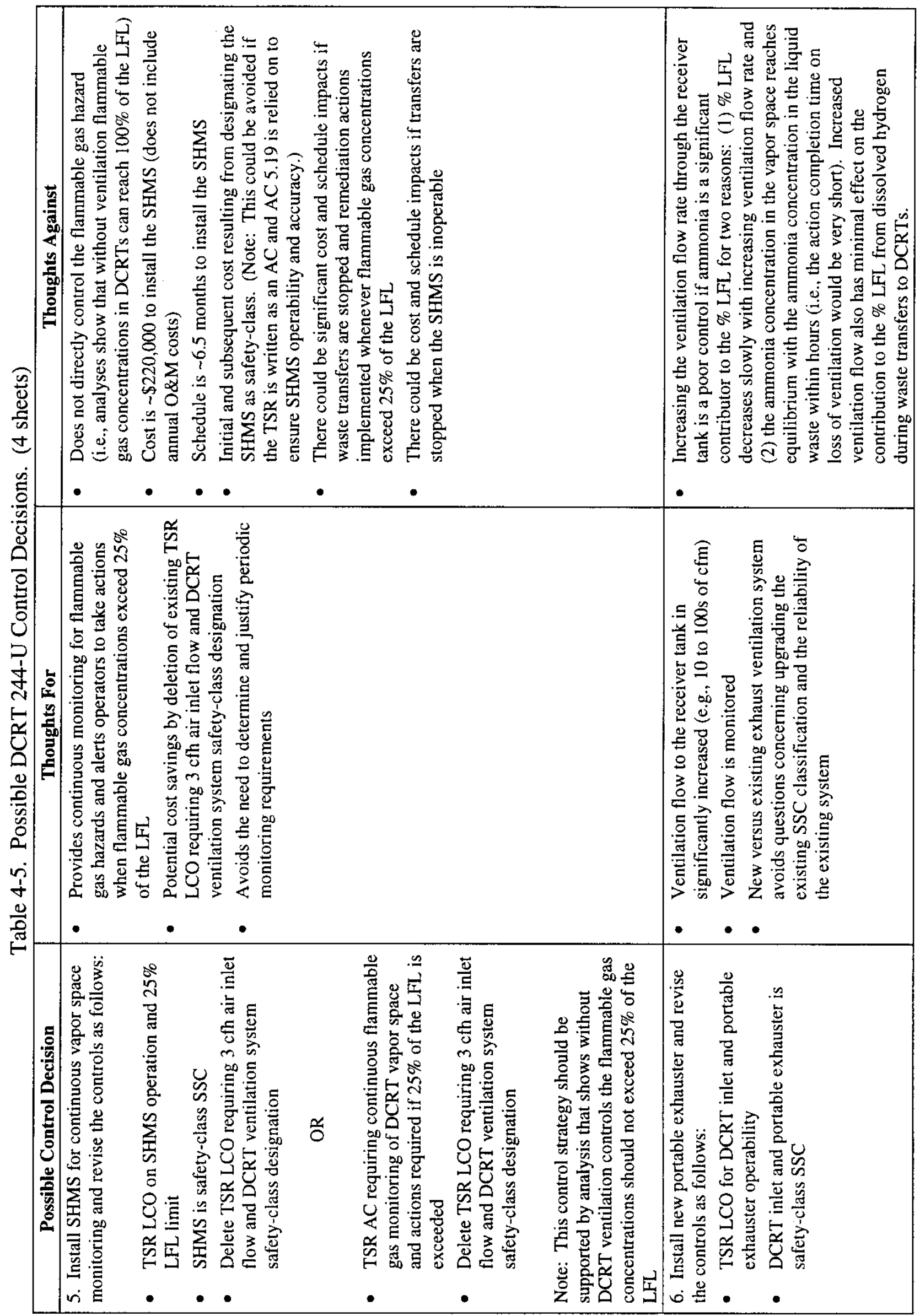


RPP-5554 REV 0

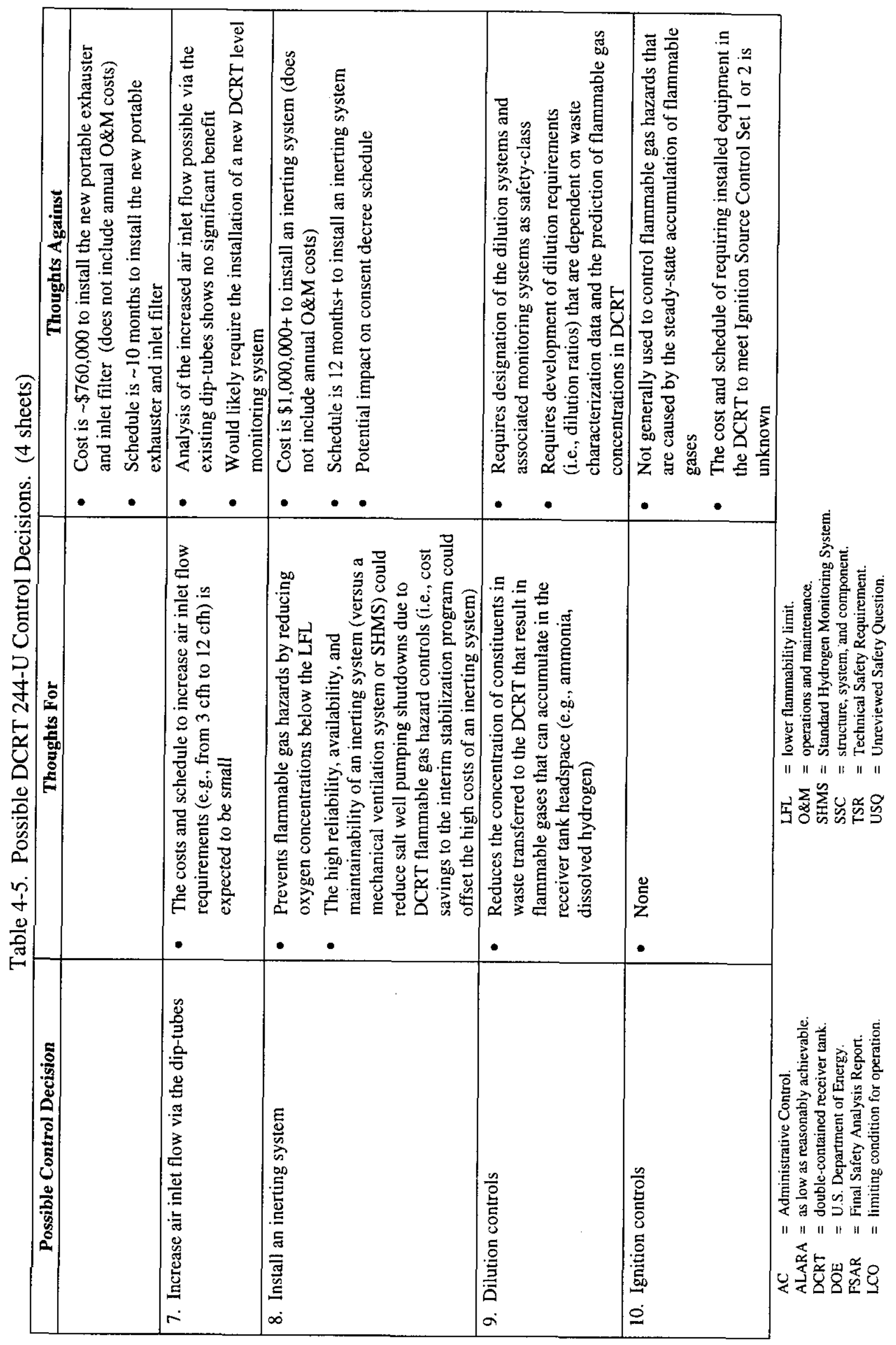


RPP-5554 REV 0

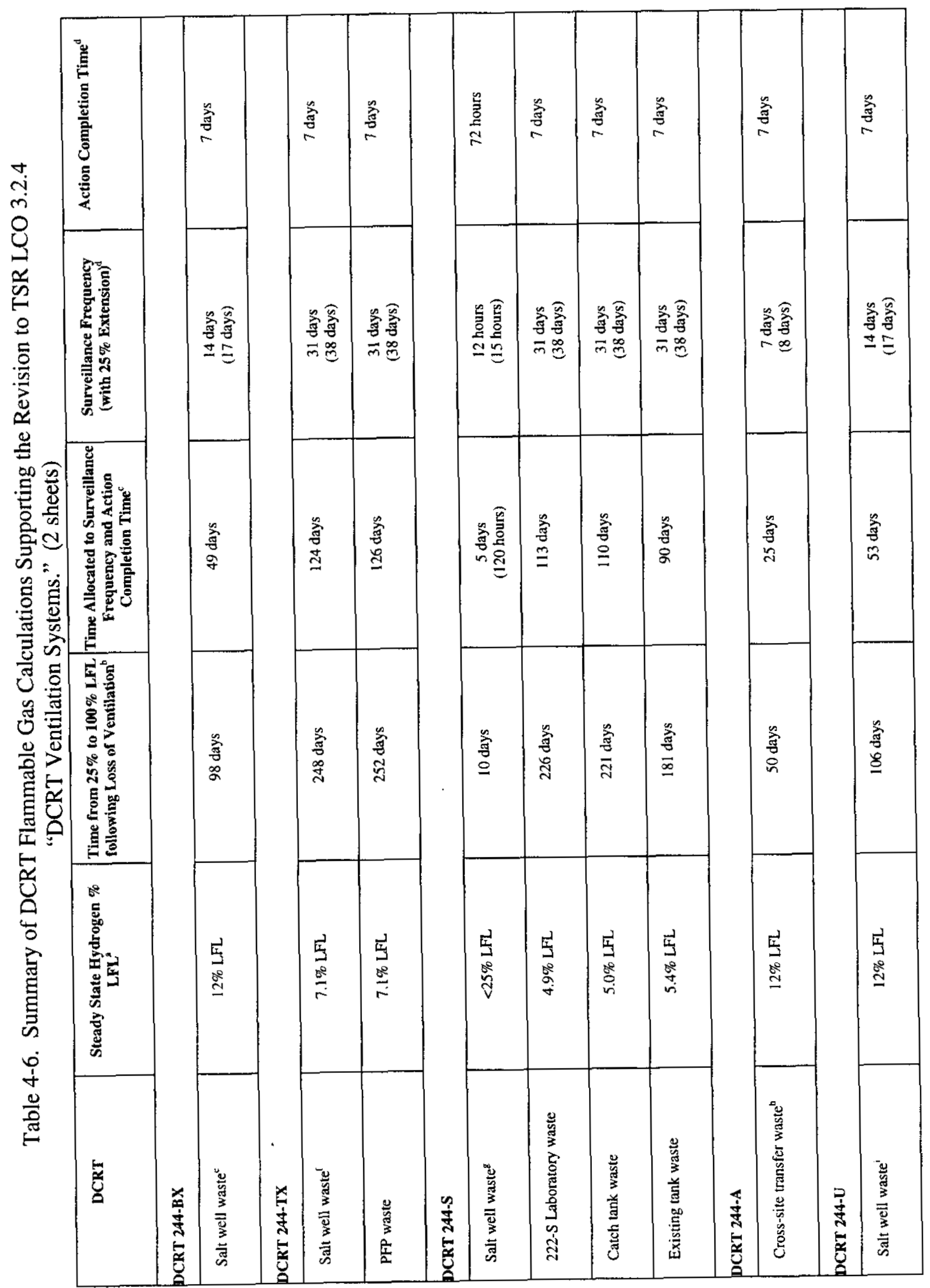


RPP-5554 REV 0

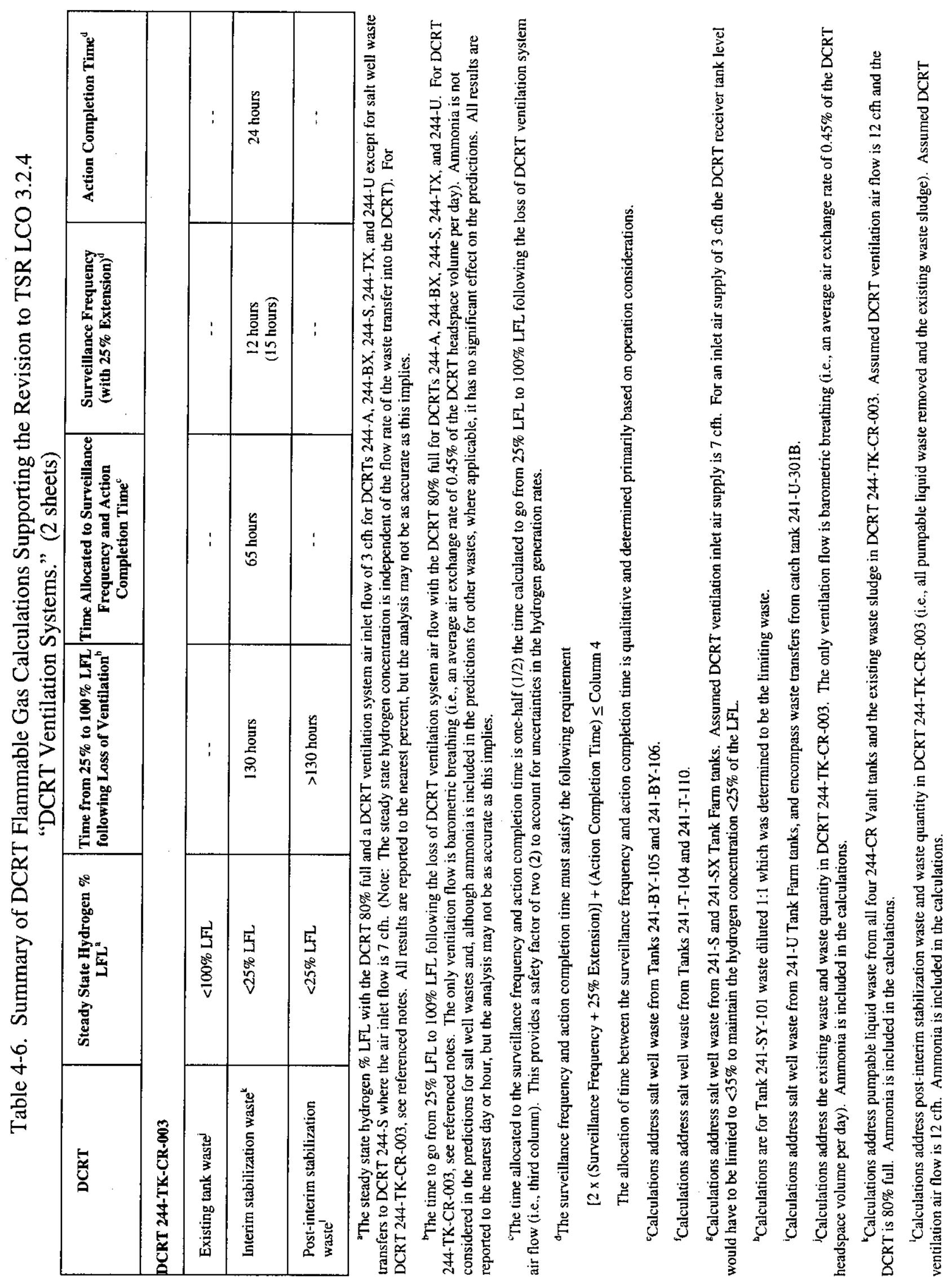


RPP-5554 REV 0

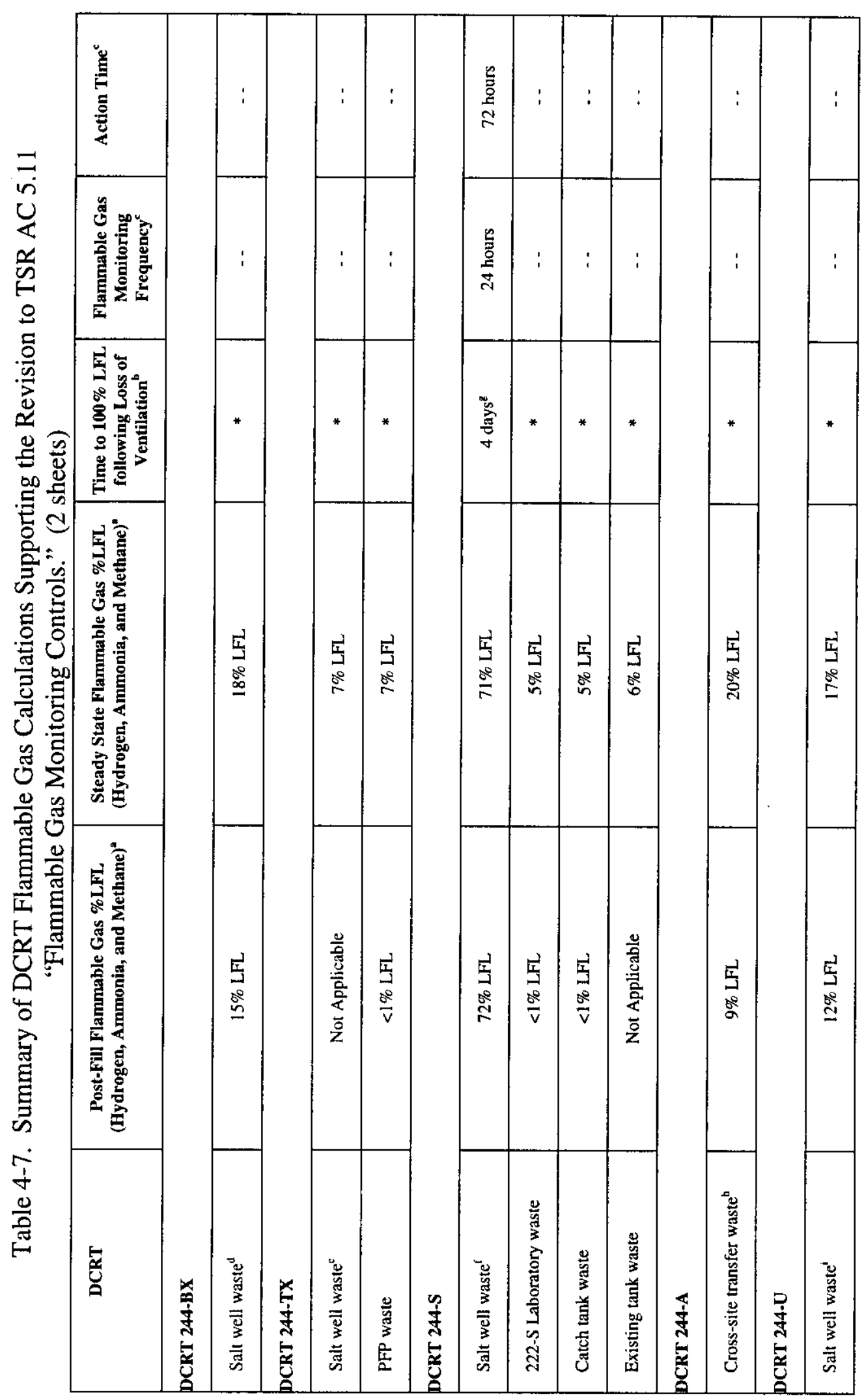




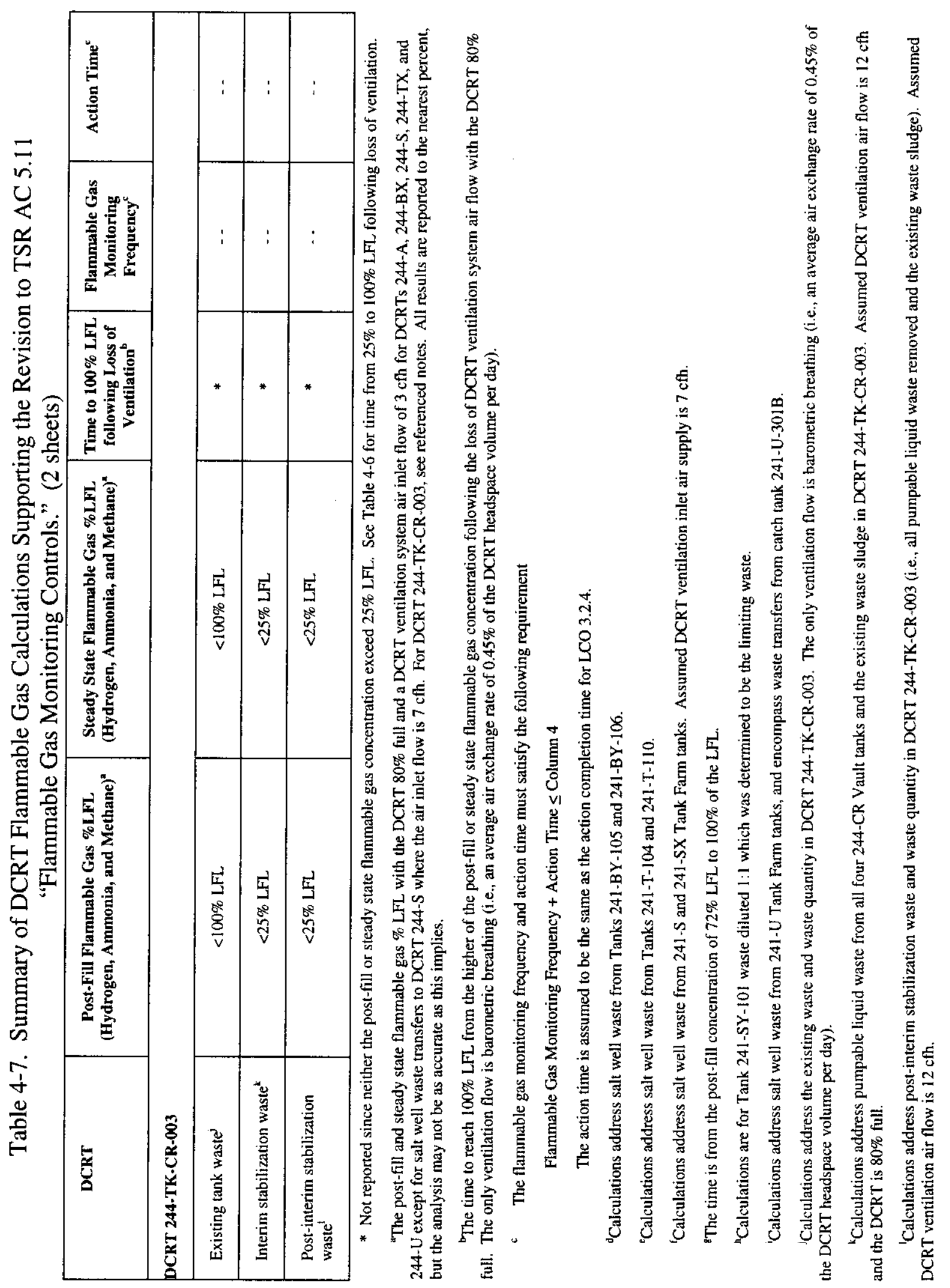


Table 4-8. Summary of DCRT Vault Flammable Gas Concentrations.

\begin{tabular}{|c|c|}
\hline DCRT Vault & $\begin{array}{c}\text { Maximum Flammable Gas } \\
\text { Concentration }\end{array}$ \\
\hline $244-\mathrm{A}$ & $58 \%$ LFL \\
\hline 244-BX & $28 \%$ LFL \\
\hline $244-S$ & \\
\hline $\begin{array}{l}\text { If no future salt well waste transfers } \\
\text { If future salt well waste transfers }\end{array}$ & $\begin{array}{c}44 \% \mathrm{LFL}^{\mathrm{L}} \\
>100 \% \mathrm{LFL}^{\mathrm{b}}\end{array}$ \\
\hline 244-TX & $33 \%$ LFL \\
\hline 244-U & $26 \% \mathrm{LFL}$ \\
\hline 244-CR Vault & \\
\hline Existing tank waste & $31 \% \mathrm{LFL}$ \\
\hline $\begin{array}{l}\text { Existing tank waste plus } 1000 \text { gal sump } \\
\text { water }\end{array}$ & $31 \% \mathrm{LFL}$ \\
\hline Tank $80 \%$ full of worst case composite & $>100 \% \mathrm{LFL}^{\mathrm{c}}$ \\
\hline Final end state of tank & $>100 \% \mathrm{LFL}^{\mathrm{d}}$ \\
\hline
\end{tabular}

Note: The table summarizes the results of predictions of the flammable gas concentration in a DCRT vault following the postulated failure of the DCRT receiver tank. The DCRT is assume to be $80 \%$ full of waste that will result in the highest flammable gas concentration. The only ventilation flow is barometric breathing (i.e., an average air exchange rate of $0.45 \%$ of the DCRT headspace volume per day).

${ }^{a}$ All results are reported to the nearest percent, but the analysis may not be as accurate as this implies.

${ }^{b}$ The predicted time to reach $100 \%$ of the LFL is 31 days.

${ }^{\mathrm{c}}$ The predicted time to reach $100 \%$ of the LFL is $\sim 52$ days.

${ }^{\mathrm{d}}$ The predicted time to reach $100 \%$ of the LFL is $>52$ days. 
RPP-5554 REV 0

This page intentionally left blank. 
RPP-5554 REV 0

\subsection{CONTROL DECISIONS}

Appendix A is the control decision record documenting the controls selected to prevent or mitigate flammable gas hazards in DCRTs at the November 16, 17, and 18, 1999, April 19, 2000, and May 20,2000 control decision meetings. This section summarizes the discussions at the control decisions meetings and documents the basis why controls were selected or not selected. Sections 5.1 to 5.7 summarize the control decision discussions for DCRTs 244-A, 244-BX, 244-S, 244-TX, and 244-U at the November 16, 17, and 18, 1999 meetings and the review and revision of these control decisions at the April 19, 2000 meeting. Sections 5.8 and 5.9 summarize the control decision discussions at the April 19,2000 and May 20, 2000 meetings on DCRT vault flammable gas controls and 244-CR Vault Tank 003 flammable gas controls, respectively. Section 5.10 provides a summary of control decision strategy discussions for DCRT 244-S.

\subsection{EXISTING CONTROLS (STATUS QUO)}

At the November 16,17, and 18, 1999 control decision meeting, there was consensus that revisions to the existing controls and/or new controls were needed to further address the risk of flammable gas hazards for DCRTs 244-A, 244-BX, 244-S, 244-TX, and 244-U (i.e., the Flammable Gas USQ for DCRTs is unlikely to be resolved and closed without some additional control[s]). Reasons for this conclusion included the following.

- Existing controls allow supplemental analysis and controls to ensure flammable gas concentrations are maintained below $25 \%$ of the LFL (i.e., the FSAR and TSRs do not completely define the safe operating envelope). DOE in TWRS-RT-SER-003, Safety Evaluation Report for the Tank Waste Remediation System (TWRS) Final Safety Analysis Report (FSAR) [HNF-SD-WM-067, Revision H, September 1998] and Technical Safety Requirements [HNF-SD-WM-006, Revision F2, August 1997] (DOE-RL 1999) stated that the Tier II Review Team does not concur with this unique approach for DCRTs.

- Analysis shows the existing DCRT ventilation system air inlet supply requirement of 3 or $5 \mathrm{cfh}$ is marginal for maintaining the flammable gas concentrations below $25 \%$ of the LFL for some salt well transfers (LMHC 1997). The analysis also only covers salt well transfers, and there is no analysis for DCRT 244-A.

- There are technical issues that DOE has identified with the analysis that remain unresolved (e.g., questions on ammonia concentrations in the transferred waste) (Kinzer 1998, Umek 1998a, Sohn 1998, and Umek 1998b). For this reason, DOE has suggested continuous flammable gas monitoring in DCRTs at all times or bypassing the DCRTs for all future transfers (Kinzer 1999).

- There are insufficient monitoring data to conclude that existing controls (i.e., DCRT ventilation air inlet supply requirements of 3 or $5 \mathrm{cfh}$ ) maintain flammable gas concentrations below $25 \%$ of the LFL. 
The concerns with the existing controls were on the DCRT ventilation system requirements (i.e., LCO 3.2.4, AC 5.11.2.d, and AC 5.12.2.c fourth bullet). There were no concerns discussed relating to the assignment of DCRTs to the Flammable Gas Facility Group Non-GRE (TSR AC 5.9.2.b, Table 5.9-1) or to the existing AC 5.10 ignition controls or the AC 5.11 flammable gas monitoring controls that apply to DCRTs.

The RPP-4941 analysis results were available for the April 19, 2000 control decision meeting (see Tables 4-6 and 4-7) and directly addressed the concerns identified in Bullets \#2 and \#3 above. This had a significant impact on the review and revision of the controls selected at the November 16, 17, and 18, 1999 control decision meetings as discussed in the following sections.

\subsection{REMOVE FROM SERVICE AND DECONTAMINATION AND DECOMMISSIONING}

This control is to bypass DCRTs 244-A, 244-BX, 244-S, 244-TX, and 244-U for future waste transfers, to ensure that waste could not be inadvcrtently transferred or drained to DCRTs, and to remove existing waste from the DCRTs. This would eliminate the flammable gas hazard, but would require time and funding to implement. Already DCRTs $244-S$ and $244-U$ are identified only as backup routes for salt well pumping, and there are active plans and projects to avoid future use of DCRTs (see Section 1.0). The consensus, however, was that decisions on DCRT flammable gas controls are needed now based on the current and expected possible use of DCRTs. That is, control decisions should not be based on plans or projects whose implementation schedules are uncertain or subject to change, and control decisions are needed to establish the required flammable gas controls for possible use of DCRTs 244-S and 244-U as backup routes for salt well pumping.

\subsection{VENTILATION CONTROLS}

There were a number of possible ventilation controls considered for DCRTs 244-A, 244-BX, 244-S, 244-TX, and 244-U ranging from simply monitoring the existing DCRT exhaust ventilation flow to various means of increasing the flow through the DCRT receiver tank headspace (see Tables 4-1 through 4-5). Possible controls where operation of the existing DCRT exhaust ventilation system is needed would have required the designation of this system as a safety-significant SSC. Because of their age and design (i.e., single exhaust fan), this was identified as having potentially significant cost and other impacts. Because any new ventilation control would have design and/or operations impacts, the benefits from increased ventilation through the DCRT receiver tank as a control were carefully explored. Based on review of the existing analysis in HNF-SD-WM-118, Calculation of Flammable Gas Mixtures in Double-Contained Receiver Tanks (LMHC 1997), and new analysis performed using the model described in RPP-4941, the following understandings were reached.

1. Hydrogen generated in the waste present in the DCRT receiver tank can be maintained below $25 \%$ of the LFL by the existing DCRT ventilation system inlet air supply. In addition, following a loss of the inlet air supply the time to reach the LFL is weeks to months. See Table 4-6. 
2. With respect to the ammonia:

A. The analysis model is conservative for low ventilation rates $(<1 \mathrm{cfm})$. The model assumes that the ammonia concentration in the vapor space is always in equilibrium with the concentration in the liquid waste phase. That is, the ammonia concentration is independent of the ventilation rate at low flows.

B. For higher ventilation rates $(>1 \mathrm{cfm}$ ), the ammonia concentration in the vapor space is calculated with a dynamic model using mass transfer limiting equations. The effect of increased ventilation on the ammonia concentration is illustrated below.

Case 1 (ammonia concentration is $2346 \mu \mathrm{g} / \mathrm{ml}$ ) (Hedengren 1999).

\begin{tabular}{|c|c|}
\hline Ventilation Rate & Post-fill Ammonia \% LFL \\
\hline $3 \mathrm{cfh}(0.05 \mathrm{cfm})$ & 36.84 \\
\hline $30 \mathrm{cfm}$ & 17.55 \\
\hline $100 \mathrm{cfm}$ & 7.87 \\
\hline
\end{tabular}

Case 2 (ammonia concentration is $1030 \mu \mathrm{g} / \mathrm{ml}):^{\mathrm{f}}$

\begin{tabular}{|c|c|}
\hline Ventilation Rate & Post-fill \% LFL* \\
\hline $3 \mathrm{cfh}(0.05 \mathrm{cfm})$ & 19.4 \\
\hline $10 \mathrm{cfh}(0.2 \mathrm{cfm})$ & 18.5 \\
\hline $5 \mathrm{cfm}$ & 13.6 \\
\hline
\end{tabular}

*Includes ammonia and hydrogen.

C. On loss of ventilation, the ammonia concentration in the vapor space will return to an equilibrium with the ammonia concentration in the liquid waste phase within hours.

D. There are uncertainties in the ammonia concentration in the liquid waste because ammonia concentration data are not available for all SST wastes and because of technical questions on whether ammonia sampling and analysis methods result in accurate determinations of the ammonia concentration in the waste.

E. Based on the conservative analysis model for ammonia and all available ammonia characterization data, the ammonia concentration in the waste can not cause flammable gas concentrations near the LFL (see Table 4-7).

\footnotetext{
${ }^{f}$ Case 2 is based on analysis performed at the November 17, 1999 control decision meeting.
} 
3. The analysis model assumes that all dissolved hydrogen in the waste is immediately released to the DCRT receiver tank headspace. Based on an analysis assuming a waste with a maximum dissolved hydrogen concentration, dissolved hydrogen could cause a DCRT receiver tank headspace concentration $>25 \%$ of the LFL, but less than the LFL, during the transfer.

4. Methane and other flammable gases are not significant contributors to the flammable gas hazard in DCRTs.

Based on the above, the consensus on ventilation controls for DCRTs 244-A, 244-BX, 244-S, 244-TX, and 244-U was to keep the DCRT ventilation system inlet air supply controls (safety-significant SSC, TSR LCO 3.2.4) with their safety function defined as preventing the accumulation of flammable gases due to steady-state releases of hydrogen. In addition, it was agreed that additional ventilation controls should not be used to control ammonia concentration or hydrogen concentration due to dissolved hydrogen. The control decision for ammonia and dissolved hydrogen was flammable gas monitoring, if necessary (see below), since there is extensive empirical data and experience that neither of these would actually result in flammable gas concentrations above the LFL. See also the discussion of dilution controls (Section 5.6), which would be viable controls for reducing the concentration of ammonia or hydrogen from dissolved hydrogen if either of these posed a significant risk of exceeding the LFL.

The DCRT exhaust ventilation system was selected as a defense-in-depth controls since it functions to provide additional ventilation to prevent the accumulation of flammable gases due to steady-state releases and is normally running to satisfy other requirements.

\subsection{FLAMMABLE GAS MONITORING CONTROLS}

There was consensus at the November 16,17, and 18, 1999 control decision meetings that flammable gas monitoring of the DCRT receiver tank headspace be selected as a new control for DCRTs 244-A, 244-BX, 244-S, 244-TX, and 244-U. Continuous monitoring was selected during salt well pumping to a DCRT receiver tank to ensure the flammable gas concentration remains below $25 \%$ of the LFL. Continuous or periodic monitoring requirements for other waste transfers to DCRTs (i.e., 222-S Laboratory, PFP) and at all other times were to be established and the basis documented in the TSRs. Flammable gas monitoring must include both hydrogen and ammonia that may be present in the DCRT receiver tank headspace. This new control addressed all questions concerning uncertainties and unknowns with the concentrations of ammonia and dissolved hydrogen in the waste and with the analysis models. It also made the DCRT flammable gas controls independent of specific salt well pumping operations (e.g., flowrate, dilution ratios). The new control also eliminated the TSR requirements in AC 5.11.2.d and $\mathrm{AC}$ 5.12.2.c, fourth bullet, for supplemental analysis and controls to ensure that flammable gas concentrations are maintained below $25 \%$ of the LFL.

Subsequent to the November 16,17, and 18, 1999 control decision meetings the analysis documented in RPP-4941 was developed. The results of this analysis (see Tables 4-7) show, with one exception, that the DCRT ventilation controls for steady-state releases of hydrogen also maintain the flammable gas concentration, including hydrogen and ammonia, to below $25 \%$ of the LFL. The one exception is DCRT 244-S if new salt well waste from 241-S or 241-SX tank 
farms is transferred to the tank. Based on this, there was consensus that the only new TSR flammable gas monitoring control required is periodic monitoring of DCRT 244-S if it were to receive new salt well waste.

\subsection{INERTING CONTROL}

A system to inert the DCRT receiver tank headspace (e.g., a nitrogen inerting system) was discussed as a possible control to prevent a flammable gas deflagration or detonation by reducing the oxygen concentration below the LFL. The potential high reliability and availability of an inerting system that would minimized shutdowns of salt well pumping due to flammable gas hazard controls, could off set the high cost of this control. There was consensus, however, that further consideration of this control was not warranted based on its cost, schedule to implement, and the limited time that DCRTs are expected to be required for salt well pumping (see Section 1.0).

\subsection{DILUTION CONTROLS}

If high ammonia or dissolved hydrogen concentrations in waste transferred to a DCRT resulted in flammable gas concentrations in the receiver tank headspace that exceeded the LFL, dilution of the waste would be selected as the control versus a ventilation control (see above). Dilution reduces the concentration of the ammonia or dissolved hydrogen and, therefore, the associated flammable gas concentration in the DCRT receiver tank headspace. Implementation of any dilution control would involve designation of the dilution systems and associated monitoring systems as safety-class and development of TSRs that establish dilution requirements (i.e., dilution ratios) that are dependent on waste characterization data and predictions of flammable gas concentrations in DCRTs. The consensus was that flammable gas monitoring, if necessary, was the preferred control, especially since neither ammonia nor dissolved hydrogen is expected to result in a flammable environment. However, since salt well pumping operations include inline dilution to protect against plugging of the waste transfer lines, dilution was identified as a defense-in-depth control.

\section{$5.7 \quad$ IGNITION CONTROLS}

Ignition controls beyond the existing controls in TSR AC 5.10 were considered only in the general discussion of flammable gas control strategies (e.g., require installed equipment in the DCRTs to meet Ignition Source Control Set 1 or 2). There was agreement that ignition controls should not be the primary control for DCRT flammable gas hazards that are caused by the steady-state accumulation of flammable gases. No revisions to the existing ignition controls for DCRTs were proposed.

\subsection{DCRT VAULT FLAMMABLE GAS CONTROLS}

There was consensus at the April 19,2000 control decision meeting that periodic monitoring of tank level in a DCRT for unexpected decreases is a new control required where the analysis shows the potential for a flammable gas hazard (i.e., flammable gas concentration could exceed 
the LFL) in the DCRT vault due to a tank leak. As shown in Table 4-8 this hazard is predicted as possible only in 244-CR Vault Tank 003 if any material is transferred to the tank (i.e., transfers from other 244-CR Vault tanks or sumps, line flushes, water additions, chemical additions, or pressure testing of transfer systems with water) and in DCRT 244-S if new salt well waste transfers to the DCRT from 241-S or 241-SX tank farms are made.

\section{$5.9 \quad 244-C R-V A U L T$ TANK 003}

At the April 19, 2000 control decision meeting, there was consensus that operation of the 244-CR Vault ventilation system as currently required by TSR LCO 3.2.4 is not required for the existing waste in 244-CR Vault Tank 003. Because of the planned use of 244-CR Vault Tank 003 for interim stabilization of the 244-CR Vault, consensus was reached at the May 20,2000 on the following controls beginning when any material is transferred to the tank (i.e., transfers from other 244-CR Vault tanks or sumps, line flushes, water additions, chemical additions, or pressure testing of transfer systems with water).

Safety-significant 244-CR Vault ventilation system that is demonstrated to provide $>12 \mathrm{cfh}$ flow through the tank headspace with the associated LCO 3.2.4 control to ensure its operability. Note: Because of the short time required to restore the ventilation system should it fail, there was consensus that an alternate backup system could also be used to provide an inlet air supply of $>12 \mathrm{cfh}$. For this backup system the flow indicator would have to meet the requirements of AC 5.19, "Process Instrumentation and Measuring and Test Equipment."

Periodic monitoring of tank level for unexpected decreases (see Section 5.8 above).

Prohibition of waste transfers to 244-CR Vault Tank 003 except for transfers of pumpable liquids from other 244-CR Vault tanks and sumps.

Based on analysis in RPP-4941 these control would be required to be maintained even after interim stabilization of the 244-CR Vault was completed (i.e., even after all pumpable liquids were removed for 244-CR Vault Tank 003). It is expected, however, that the 244-CR Vault interim stabilization project would develop a basis and develop an Authorization Basis amendment to relax or remove all controls following completion of interim stabilization activities.

\subsection{DCRT 244-S CONTROL STRATEGY}

Based on the control decisions discussed in the previous sections and summarized in Attachment 1, the controls for DCRT 244-S are highly dependent on whether there will be future transfers of salt well waste to this DCRT from the 241-S or 241-SX tank farms. Because the required control to prevent flammable gas hazards are significantly more restrictive if future salt well pumping to DCRT 244-S occurs, and because salt well pumping to DCRT 244-S is not expected, there was consensus to develop two sets of controls. The first set based on prohibiting 
salt well transfers would be implemented upon its review and approval. The second set assuming salt well transfer occurs would be developed, but would not be implemented until needed. With this strategy, the added implementation and operating costs required with the second set of controls would be delayed and likely avoided entirely. 
RPP-5554 REV 0

This page intentionally left blank. 


\subsection{REFERENCES}

Bacon, R. F., 1996, Justification for Continued Operation for Flammable Gas Unreviewed Safety Question, (letter 9653371 to J. E. Kinzer, DOE-RL, July 31), Westinghouse Hanford Company, Richland, Washington.

CHG, 2000a, Tank Waste Remediation System Final Safety Analysis Report,

HNF-SD-WM-SAR-067, Rev. 1, as amended, CH2M HILL Hanford Group, Inc.,

Richland, Washington.

CHG, 2000b, Tank Waste Remediation System Technical Safety Requirements,

HNF-SD-WM-TSR-006, Rev. 1, as amended, CH2M HILL Hanford Group, Inc.,

Richland, Washington.

CHG, 2000c, Methodology for Predicting Flammable Gas Mixtures in Double-Contained Receiver Tanks, RPP-4941, Rev. 0-A, CH2M HILL Hanford Group, Inc., Richland, Washington.

DOE, 1994, Airborne Release Fractions/Rates and Respirable Fractions for Nonreactor Nuclear Facilities, DOE-HDBK-3010-94, U.S. Department of Energy, Washington, D.C.

DOE-RL, 1999, Safety Evaluation Report for the Tank Waste Remediation System (TWRS) Final Safety Analysis Report (FSAR) [HNF-SD-WM-067, Revision H, September 1998] and Technical Safety Requirements [HNF-SD-WM-006," Revision F2, August 1997], TWRS-RT-SER-003, U.S. Department of Energy, Richland Operations Office, Richland, Washington.

FDNW, 1999, Combustion Accident Analysis for Double-Contained Receiver Tanks (DCRTs)

244-S and 244-TX, HNF-4526, Fluor Daniel Northwest, Inc., Richland, Washington.

FFS, 2000, Updated Double-Contained Receiver Tank Combustion Accident Analysis, RPP-6244, Rev. 0, Fluor Federal Services, Richland, Washington.

Hedengren, D. C., 1999, Ventilation Requirements for Saltwell Pumping to 244-U

Double-Contained Receiver Tank, (letter 74B40-99-029 to J. G. Field, February 18), Lockheed Martin Hanford Company, Richland, Washington.

Kinzer, J. E., 1998, Transmittal of Tank Waste Remediation System (TWRS) Review Comment Records (RCR) on Flammable Gas Calculation Notes 116, 117, and 118, (letter 98-SCD-026 to H. J. Hatch, FDH, February 27), U.S. Department of Energy, Richland Operations Office, Richland, Washington.

Kinzer, J. E., 1999, Responses to Review Comment Records (RCR) on Flammable Gas Calculation Notes 116, 117, and 118, (letter 99-TSD-056, to R. D. Hanson, FDH, November 1), U.S. Department of Energy, Richland Operations Office, Richland, Washington. 
LMHC, 1997, Calculation of Flammable Gas Mixtures in Double-Contained Receiver Tanks, HNF-SD-WM-118, Lockheed Martin Hanford Corporation, Richland, Washington.

LMHC, 1999a, Empirical Rate Equation Model and Rate Calculations of Hydrogen Generation for Hanford Tank Waste, HNF-3851, Lockheed Martin Hanford Corporation, Richland, Washington.

LMHC, 1999b, Evaluation of Flammable Gas Monitoring and Ventilation System Alternatives for Double-Contained Receiver Tanks, RPP-5162, Lockheed Martin Hanford Corporation, Richland, Washington.

PNNL, 1998, Flammable Gas Issues in Double-Contained Receiver Tanks, PNNL-11836, Revision 2, Pacific Northwest National Laboratory, Richland, Washington.

Resource Conservation and Recovery Act of 1976, as amended, 42 USC 6901 et seq.

Sohn, C., 1998, Disposition of Tank Waste Remediation System Review Comment Records (RCR) on Flammable Gas Calculation Notes 116, 117, and 118, (letter 98-SCD-097 to R. D. Hanson, FDH, July 30), U.S. Department of Energy, Richland Operations Office, Richland, Washington.

Umek, A. M., 1998a, Action Plan for Disposition of Tank Waste Remediation System Review Comment Records on Flammable Gas Calculation Notes 116, 117, and 118, (letter FDH-9851853A R1 to J. E. Kinzer, DOE-RL, April 10), Fluor Daniel Hanford Company, Richland, Washington.

Umek, A. M., 1998b, Flammable Gas Project: Disposition of Tank Waste Remediation System Review Comment Records on Flammable Gas Calculation Notes 116, 117, and 118, (letter FDH-9856475A R2, to C. L. Sohn, DOE-RL, October 23), Fluor Daniel Hanford, Richland, Washington.

Wagoner, J. D., 1996, Definition and Declaration of Flammable Gas Unreviewed Safety Question (USQ), (letter 96-WSD-283 to H. J. Hatch, FDH, November 1), U.S. Department of Energy, Richland Operations Office, Richland, Washington.

WHC, 1996, Summary of Flammable Gas Hazards and Potential Consequences in Tank Waste Remediation System Facilities at the Hanford Site, WHC-SD-WM-TI-753, Westinghouse Hanford Company, Richland, Washington. 
RPP-5554 REV 0

\section{APPENDIX A}

\section{CONTROL DECISION RECORD FOR FLAMMABLE GAS HAZARDS} IN DOUBLE-CONTAINED RECEIVER TANKS 


\section{RPP-5554 REV 0}

This page intentionally left blank.

A-ii 


\section{A1.0 CONTROL DECISION RECORD}

\section{A1.1 HAZARD/ACCIDENT TITLE:}

Flammable gas hazards (i.e., deflagrations or detonations) in DCRTs (i.e., 244-A, 244-BX, 244-S, 244-TX, 244-U, and 244-CR Vault Tank 003).

\section{A1.1.1 Structures, Systems, and Components (SSCs)}

Note: Revisions to existing controls and new controls are in bold italics

\begin{tabular}{|c|c|c|c|c|}
\hline \multirow{2}{*}{$\begin{array}{l}\text { Structures, Systems, and } \\
\text { Components }\end{array}$} & \multicolumn{2}{|c|}{ Classification } & \multirow{2}{*}{ Safety Function } & \multirow{2}{*}{ Comments } \\
\hline & $\mathrm{SC}^{\mathrm{a}}$ & $S S^{b}$ & & \\
\hline $\begin{array}{l}\text { Double-contained } \\
\text { receiver tank ventilation } \\
\text { systems }\end{array}$ & -- & $X$ & $\begin{array}{l}\text { The safety function of the DCRT } \\
\text { ventilation systems are to prevent } \\
\text { the accumulation of flammable } \\
\text { gases due to steady-state releases, } \\
\text { thus decreasing the frequency of } \\
\text { the Flammable Gas Deflagrations } \\
\text { accident. }\end{array}$ & -- \\
\hline
\end{tabular}




\section{A1.1.2 Technical Safety Requirements (TSRs)}

Note: Revisions to existing controls and new controls are in bold italics.

\begin{tabular}{|c|c|c|}
\hline Control & Safety Function & Comments \\
\hline $\begin{array}{l}\text { DCRT ventilation systems } \\
(\mathrm{LCO} 3.2 .4)\end{array}$ & $\begin{array}{l}\text { Ensures a minimum ventilation } \\
\text { flow to prevent the accumulation } \\
\text { of flammable gases due to } \\
\text { steady-state releases. }\end{array}$ & - \\
\hline $\begin{array}{l}\text { Flammability controls } \\
\text { - Flammable Gas Facility } \\
\text { Groups defined in (FSAR) } \\
\text { Appendix K (i.e., DCRTs } \\
\text { 244-A, 244-BX, 244-S, } \\
\text { 244-TX, and 244-U are } \\
\text { "Non-GRE" and 244-CR } \\
\text { Vault Tank 003 is Facility } \\
\text { Group 3) } \\
\text { (AC 5.9.2.b, Table 5.9-1) }\end{array}$ & $\begin{array}{l}\text { Controls ensure that flammable } \\
\text { gas hazards are managed. }\end{array}$ & 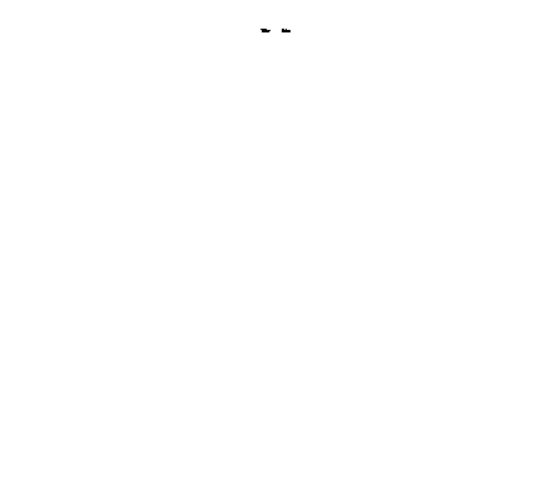 \\
\hline $\begin{array}{l}\text { Waste Transfer } \\
\text { Prohibitions (i.e., } \\
\text { prohibition of specific } \\
\text { waste transfers to DCRTs) } \\
\text { (Revision to AC 5.9) }\end{array}$ & $\begin{array}{l}\text { Prevents waste transfers that } \\
\text { may result in flammable gas } \\
\text { hazards that are not addressed by } \\
\text { existing analyses and/or } \\
\text { controls. }\end{array}$ & $\begin{array}{l}\text { Waste transfers to } 244-C R \text { Vault } \\
\text { Tank } 003 \text { are prohibited, except for } \\
\text { waste transfers from other } 244-C R \\
\text { vault tanks or sumps. } \\
\text { Waste transfers to DCRT } 244-S \\
\text { from } 241-S \text { or } 241-S X \text { tank farms } \\
\text { are prohibited unless additional } \\
\text { controls are implemented. }\end{array}$ \\
\hline $\begin{array}{l}\text { DCRT Vault Leak } \\
\text { Detection (i.e., periodic } \\
\text { monitoring of tank level for } \\
\text { unexpected decreases) } \\
\text { (Revision to AC 5.9) }\end{array}$ & $\begin{array}{l}\text { Ensures a leak into the vault is } \\
\text { detected so that actions to } \\
\text { prevent accumulation of } \\
\text { flammable gas in the vault can } \\
\text { be taken. }\end{array}$ & $\begin{array}{l}\text { Only applies to 244-CR Vault Tank } \\
\text { o03 if any material is transferred to } \\
\text { the tank (i.e., transfers from other } \\
244-C R \text { Vault tanks or sumps, line } \\
\text { flushes, water additions, chemical } \\
\text { additions, or pressure testing of } \\
\text { transfer systems with water) and to } \\
\text { DCRT } 244-S \text { if new salt well waste } \\
\text { transfers to the DCRT from } 241-S \text { or } \\
241-S X \text { tank farms are made. }\end{array}$ \\
\hline $\begin{array}{l}\text { Ignition Controls detailed in } \\
\text { (FSAR) Appendix K (i.e., } \\
\text { existing DCRT flammable } \\
\text { gas ignition source control } \\
\text { set requirements) } \\
\text { (AC } 5.10, \text { Table } 5.10-1 \text { ) }\end{array}$ & $\begin{array}{l}\text { Reduces frequency of a } \\
\text { flammable gas deflagration }\end{array}$ & - \\
\hline
\end{tabular}




\section{RPP-5554 REV 0}

\begin{tabular}{|c|c|c|}
\hline Control & Safety Function & Comments \\
\hline $\begin{array}{l}\text { Flammable Gas Monitoring } \\
\text { Controls detailed in (FSAR) } \\
\text { Appendix K (i.e., existing } \\
\text { DCRT flammable gas } \\
\text { monitoring requirements) } \\
\text { (AC 5.11, Table 5.11-1) }\end{array}$ & $\begin{array}{l}\text { Reduces frequency of a } \\
\text { flammable gas deflagration }\end{array}$ & - \\
\hline $\begin{array}{l}\text { DCRT Flammable Gas } \\
\text { Monitoring Controls } \\
\text { (Revision to AC 5.11) }\end{array}$ & $\begin{array}{l}\text { Reduces frequency of a } \\
\text { flammable gas deflagration }\end{array}$ & $\begin{array}{l}\text { Periodic monitoring of the } \\
\text { flammable gas concentration in } \\
\text { DCRT 244-S if new salt well waste } \\
\text { transfers to the DCRT from } 241-S \text { or } \\
24 I-S X \text { tank farms are made. }\end{array}$ \\
\hline $\begin{array}{l}\text { Flammable Gas } \\
\text { Monitoring Controls } \\
\text { See Comments }\end{array}$ & 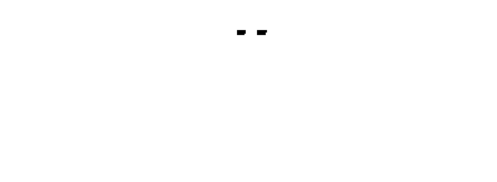 & $\begin{array}{l}\text { The existing flammable gas } \\
\text { monitoring requirements in } \\
\text { AC 5.11.2.d, "DCRT Ventilation } \\
\text { Requirements," are deleted. }\end{array}$ \\
\hline $\begin{array}{l}\text { Transfer Controls } \\
\text { See Comments }\end{array}$ & $\cdots$ & $\begin{array}{l}\text { The existing transfer waste } \\
\text { compatibility requirement in } \\
\text { AC 5.12.2.c fourth bullet, "DCRT } \\
\text { Time to LFL Determination," is } \\
\text { deleted. }\end{array}$ \\
\hline $\begin{array}{l}\text { Emergency Preparedness } \\
(\mathrm{AC} 5.14)\end{array}$ & $\begin{array}{l}\text { Mitigate the consequences of a } \\
\text { flammable gas deflagration. }\end{array}$ & - \\
\hline $\begin{array}{l}\text { HEPA Filter Controls } \\
\text { (source term) } \\
\text { (AC 5.18) }\end{array}$ & $\begin{array}{l}\text { Reduces the consequences from a } \\
\text { possible HEPA filter failure by } \\
\text { limiting the inventory available }\end{array}$ & $\begin{array}{l}\text { Applies to all HEPA filters, prefilters, } \\
\text { and inlet filters in the ventilation } \\
\text { system. Also protects accident } \\
\text { analysis assumptions regarding } \\
\text { HEPA filter release amounts. }\end{array}$ \\
\hline $\begin{array}{l}\text { Process Instrumentation and } \\
\text { Measuring and Test } \\
\text { Equipment } \\
\text { (AC 5.19) }\end{array}$ & $\begin{array}{l}\text { Ensures instrumentation used to } \\
\text { monitor the concentration of } \\
\text { flammable gases is maintained. }\end{array}$ & $\ldots$ \\
\hline
\end{tabular}




\section{RPP-5554 REV 0}

\section{A1.1.3 Defense-in Depth Controls}

Note: Revisions to existing controls and new controls are in bold italics.

\begin{tabular}{|l|l|l|}
\hline \multicolumn{1}{|c|}{ Control } & \multicolumn{1}{c|}{ Safety Function } & \multicolumn{1}{c|}{ Comments } \\
\hline $\begin{array}{l}\text { DCRT exhaust ventilation } \\
\text { system }\end{array}$ & $\begin{array}{l}\text { Provides additional ventilation to } \\
\text { prevent the accumulation of } \\
\text { flammable gases due to } \\
\text { steady-state releases }\end{array}$ & $\begin{array}{l}\text { Credit for the DCRT ventilation } \\
\text { exhaust system is not include in } \\
\text { the flammable gas analysis } \\
\text { because there is no inlet air path } \\
\text { to the DCRTs (except for 244-U) } \\
\text { and ventilation flow rate can not } \\
\text { be measured. }\end{array}$ \\
\hline $\begin{array}{l}\text { Dilution of salt well waste } \\
\text { transferred to the DCRT from } \\
\text { SSTs. }\end{array}$ & $\begin{array}{l}\text { Reduces the concentration of } \\
\text { ammonia and constituents that } \\
\text { affect the generation of } \\
\text { hydrogen in the DCRT. }\end{array}$ & $\begin{array}{l}\text { Dilution is required to prevent } \\
\text { plugging of the waste transfer } \\
\text { line. }\end{array}$ \\
\hline
\end{tabular}


RPP-5554 REV 0

ATTACHMENT 1

\section{AGENDA FOR CONTROL DECISION MEETINGS ON NOVEMBER 16, 17, AND 18, 1999 TO ADDRESS DOUBLE-CONTAINED RECEIVER TANKS \\ FLAMMABLE GAS HAZARDS}


RPP-5554 REV 0

This page intentionally left blank.

Att 1-ii 


\section{AGENDA FOR CONTROL DECISION MEETINGS ON \\ NOVEMBER 16, 17, AND 18, 1999 TO ADDRESS \\ DOUBLE-CONTAINED RECEIVER TANKS \\ FLAMMABLE GAS HAZARDS}

November 16, 1999 (Tuesday)

Note: All times are estimates and may vary.

8:30-9:00 Introduction
A. Purpose
B. Scope
C. Process

9:00-9:15 Background
A. Flammable gas USQ
B. Potential DCRT flammable gas hazards
C. Basis of existing controls (i.e., JCO)

9:15-10:00 Description/Planned Use of DCRTs (244-A, 244-BX, 244-S, 244-TX, 244-U)

10:00-10:15 Break

10:15-10:30 DCRT vapor sampling and ventilation flow measurements (RP-2923, Rev. 0-B)

10:30-10:45 Existing and New DCRT Consequence Analyses (HNF-4526)

10:45-11-00 Predictions of DCRT flammable gas concentrations [CN-118/RPP-4941 (draft)]

11:00-11:30 Evaluation of Flammable Gas Monitoring and Ventilation System Alternatives for DCRTs (RPP-5162)

\section{1:30-12:30 General Flammable Gas Control Strategies}

A. Existing DCRT flammable gas controls

B. Alternative DCRT flammable gas control strategies 
November 17, 1999 (Wednesday)

Note: All times are estimates and may vary.

\section{8:30-10:15 DCRT 244-BX Control Decision}
A. Existing Controls
B. Possible Controls
An initial list of possible new or revised controls with observations for and against will be presented to initiate the control decision discussion
C. Selected Controls

\section{0:15-10:30 Break}

\section{0:30-11:30 DCRT 244-TX Control Decision}
A. Existing Controls
B. Possible Controls
An initial list of possible new or revised controls with observations for and against will be presented to initiate the control decision discussion
C. Selected Controls

\section{1:30-12:30 DCRT 244-S Control Decision}
A. Existing Controls
B. Possible Controls An initial list of possible new or revised controls with observations for and against will be presented to initiate the control decision discussion
C. Selected Controls

\section{November 18, 1999 (Thursday)}

\section{8:30-9:15 DCRT 244-U}
A. Existing Controls
B. Possible Controls
An initial list of possible new or revised controls with observations for and against will be presented to initiate the control decision discussion
C. Selected Controls

\section{9:15-10:15 DCRT 244-A Control Decision}
A. Existing Controls
B. Possible Controls
An initial list of possible new or revised controls with observations for and against will be presented to initiate the control decision discussion
C. Selected Controls

10:15-10:30 Break

10:30-12:30 Summary and Path Forward 
RPP-5554 REV 0

\section{ATTACHMENT 2}

\section{ATTENDANCE LISTS FOR CONTROL DECISION MEETINGS NOVEMBER 16, 17, AND 18, 1999 TO ADDRESS \\ DOUBLE-CONTAINED RECEIVER TANKS \\ FLAMMABLE GAS HAZARDS}

Att 2-i 
RPP-5554 REV 0

This page intentionally left blank.

Att 2-ii 


\section{RPP-5554 REV 0}

Attendance List for November 16, 1999.

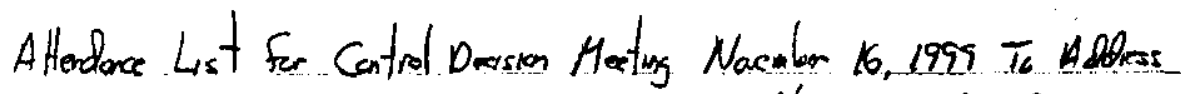
DCRT Flomde Gos ltarad.

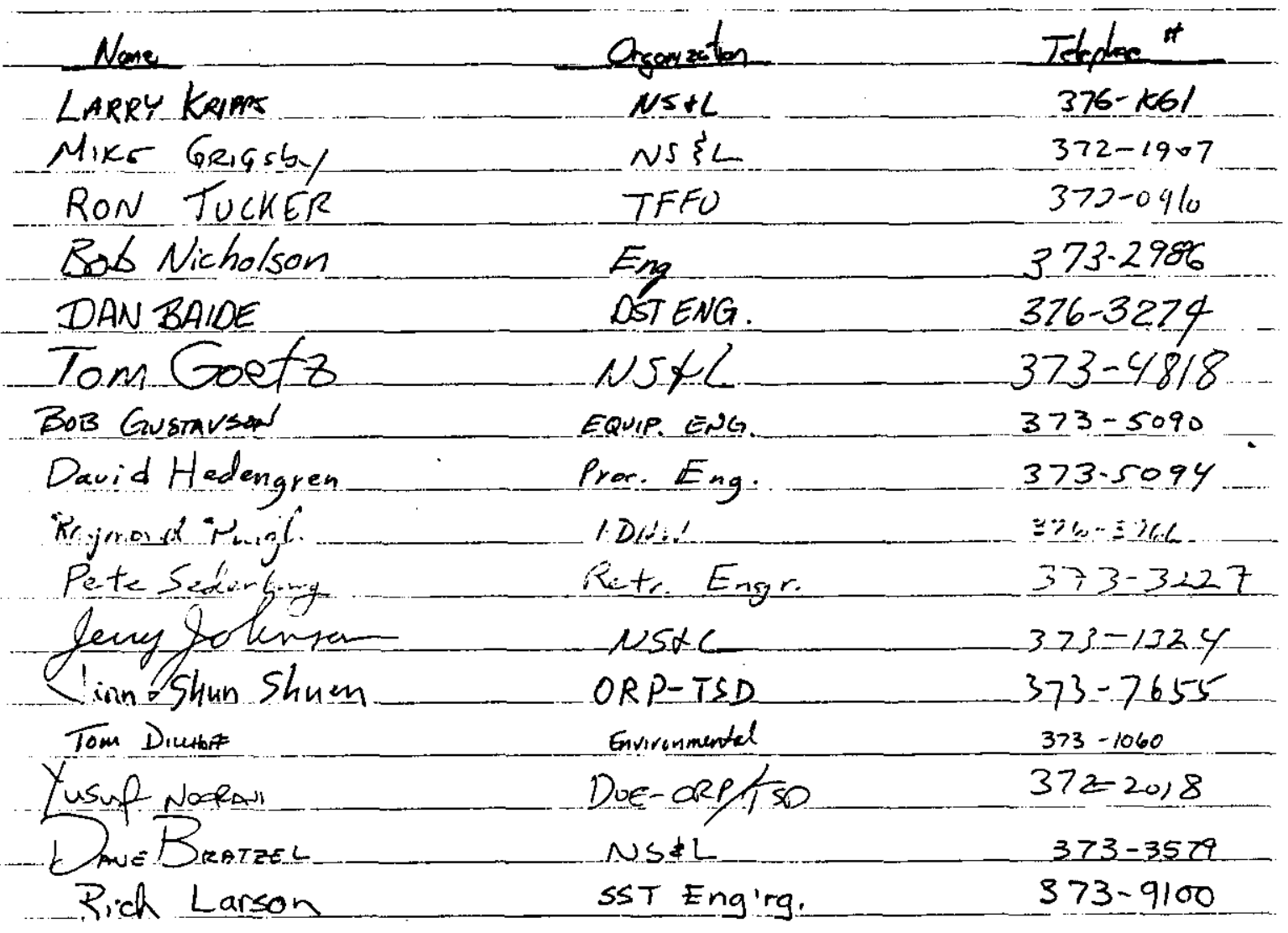




\section{RPP-5554 REV 0}

Attendance List for November 17, 1999.

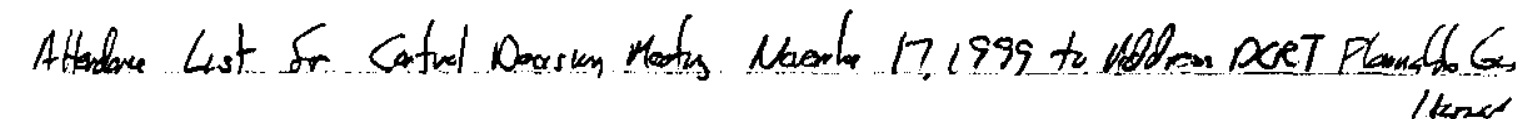

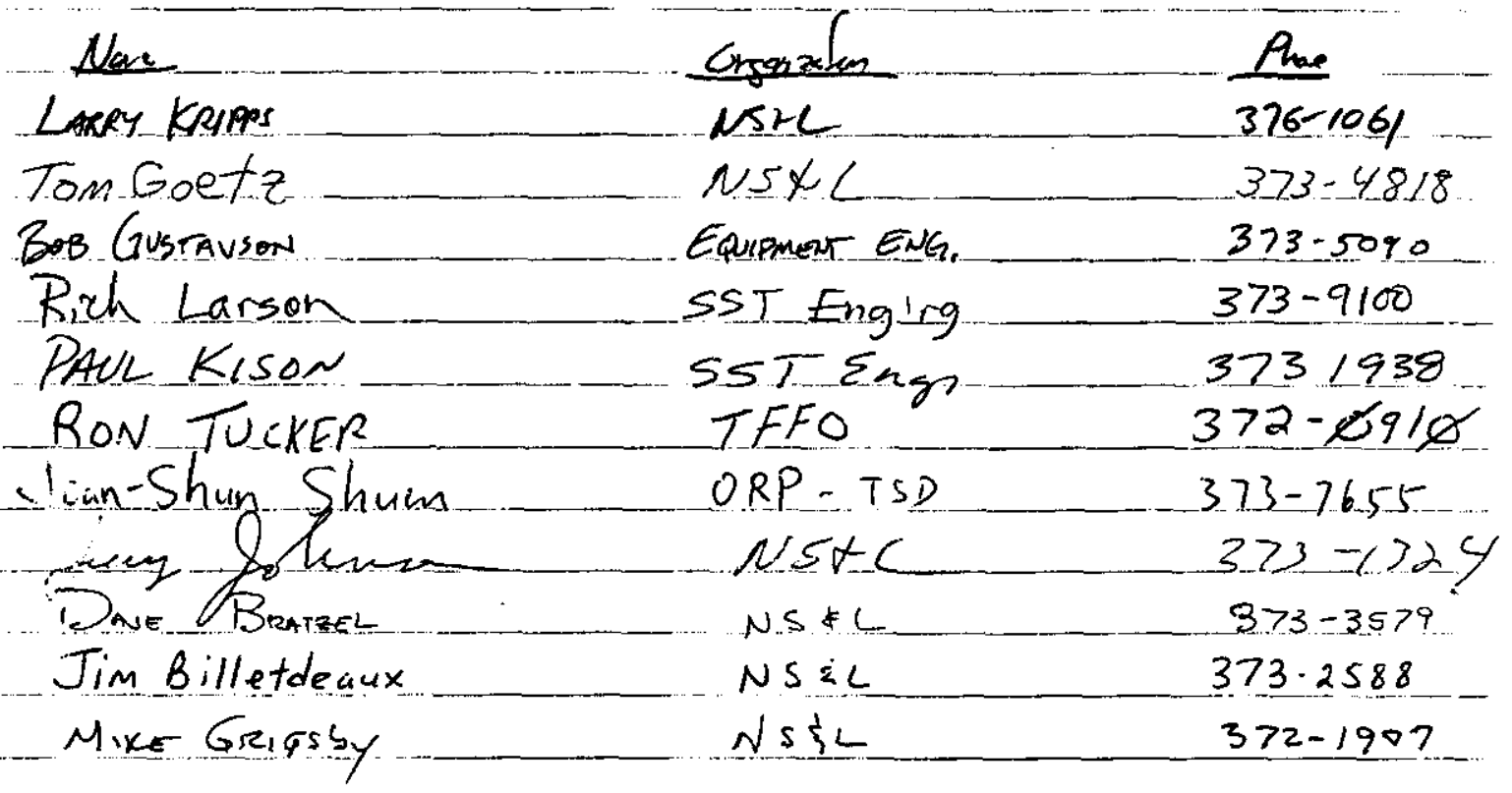




\section{RPP-5554 REV 0}

Attendance List for November 18, 1999.

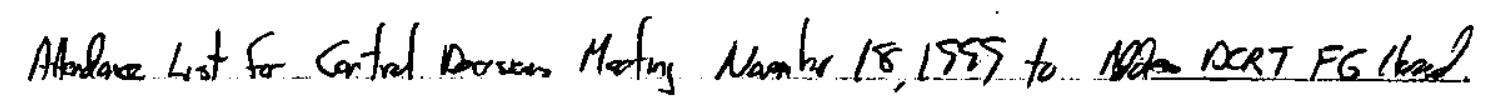

\begin{tabular}{|c|c|c|}
\hline on & Orgataterer & Then \\
\hline LARRY KRIPU & & $376-1061$ \\
\hline Hismen. & Sactaress & $572-067 ?$ \\
\hline m Goetz & WSAL & 481.8 \\
\hline BALDE & DST ENG. & $376-3274$ \\
\hline & & 996 \\
\hline Ro & & \\
\hline & & \\
\hline Jim Billetdeaux & $\frac{N S \sum_{c}}{P_{\text {ro. Ena. }}}$ & $\frac{373-2588}{373-5094}$ \\
\hline $\begin{array}{l}\text { Dave Heden } \\
\text { Paul Kiso. }\end{array}$ & & $\begin{array}{l}373-50 \\
373 / 9\end{array}$ \\
\hline
\end{tabular}




\section{RPP-5554 REV 0}

This page intentionally left blank.

Att 2-4 
RPP-5554 REV 0

\section{ATTACHMENT 3}

PURPOSE, SCOPE, AND PROCESS FOR CONTROL DECISION MEETINGS TO ADDRESS DOUBLE-CONTAINED RECEIVER TANKS

FLAMMABLE GAS HAZARDS 
RPP-5554 REV 0

This page intentionally left blank.

Att 3-ii 


\section{CONTROL DECISION MEETINGS TO ADDRESS DOUBLE-CONTAINED RECEIVER TANKS FLAMMABLE GAS HAZARDS}

Note: Controls include safety-class and safety-significant structures, systems, and components (SSCs); technical safety requirements (TSRs); and other controls that provided defense-in-depth or environmental protection.

\section{Purpose:}

The purpose of the control decision meetings is to review existing controls and potentially select new or revised controls to prevent or mitigate flammable gas hazards in DCRTs. The control decisions and their basis support the resolution and closure of the Flammable Gas Unreviewed Safety Question (USQ) for DCRTs.

\section{Scope:}

The scope of the control decision meetings covers potential flammable gas hazards in five DCRTs. DCRTs are interim, short-term (lag) storage facilities and valve pits for waste transfer operations. DCRTs are 244-A and 244-BX located in the 200 East Area and 244-S, 244-TX, and 244-U located in the 200 West Area. These DCRTs are described in the River Protection Project (RPP) Final Safety Analysis Report (FSAR) (HNF-SD-WM-SAR-067, Revision 1). The 244-CR Vault located in the 200 East Area also contains one tank (244-CR-003) that is identified in the FSAR as a DCRT based on its potential use for short-term storage of salt well waste from the 241-C Tank Farm. However, because of the uncertainty associated with its future use as a DCRT, Tank 244-CR-003 is not included in the scope of these control decision meetings.

\section{Process:}

The control decision process and the criteria for control decisions are described in the FSAR along with the methodology for the hazard and accident analyses whose results are used to identify controls. Control decision criteria are summarized in Exhibit I.

Control decisions will be based on the best available information from the hazard and accident analyses and on the technical expertise and experience of the meeting participants. Decisions will be made by consensus.

Required participants in the DCRT flammable gas hazard control decision meetings are representatives from operations, engineering (including Design Authority and cognizant engineers), process engineering, and nuclear safety and licensing. Control decision meeting participants may also include representatives from safety services, emergency management, nuclear regulatory compliance, quality assurance, radiological control, environmental, interim stabilization operations and engineering, and retrieval engineering. Personnel responsible for developing the information or performing the analysis supporting DCRT control decisions will be present at the control decision meetings. U.S. Department of Energy (DOE) Office of River Protection (ORP) staff have been invited to observe the control decision meetings. 
The control decision meeting discussions will be documented, including the control decisions (see Exhibit II). The control decisions and their basis will be incorporated into the FSAR and TSRs through an Authorization Basis amendment to resolve and close the Flammable Gas USQ for DCRTs. Contractor (i.e., Tier I) and DOE review and approval of the Authorization Basis amendment will be required. 


\section{SUMMARY OF CONTROL DECISION CRITERIA}

Note: FSAR Section 3.3.1.5, "Controls Identification," contains a complete discussion of control decision criteria.

Control decision criteria are based on the following documents.

DOE 5480.23, Nuclear Safety Analysis

DOE 5480.22,. Technical Safety Requirements

DOE-STD-3009-94, Preparation Guide for U.S. Department of Energy Nonreactor Nuclear Facility Safety Analysis Reports

WHC-CM-4-46, Nonreactor Facility Safety Analysis Manual, Section 6, "Technical Safety Requirements," Rev. 1, and Section 9, "Safety Classification of Structures, Systems, and Components,: Rev. 2.

\section{Risk Evaluation Guidelines:}

Radiological Risk Guidelines

\begin{tabular}{|l|l|l|l|}
\hline \multirow{2}{*}{ Frequency category } & \multirow{2}{*}{ Frequency range $(\mathrm{yr}-1)$} & \multicolumn{2}{|l|}{ Effective dose equivalent (rem) } \\
\cline { 3 - 4 } & & Onsite & Offsite \\
\hline Anticipated & $>10^{-2}$ to $\leq 10^{0}$ & 0.5 & 0.1 \\
\hline Unlikely & $>10^{-4}$ to $\leq 10^{-2}$ & 5 & 0.5 \\
\hline Extremely unlikely & $>10^{-6}$ to $\leq 10^{-4}$ & 10 & 4 \\
\hline
\end{tabular}

Toxicological Risk Guidelines

\begin{tabular}{|l|c|c|c|}
\hline \multirow{2}{*}{ Frequency category } & \multirow{2}{*}{ Frequency range (yr-1) } & \multicolumn{2}{|c|}{ Primary concentration guidelines } \\
\cline { 3 - 4 } & & Onsite & Offsite \\
\hline Anticipated & $>10^{-2}$ to $\leq 10^{0}$ & $\leq$ ERPG-1 & $\leq$ PEL-TWA \\
\hline Unlikely & $>10^{-4}$ to $\leq 10^{-2}$ & $\leq$ ERPG-2 & $\leq$ ERPG-1 \\
\hline Extremely unlikely & $>10^{-6}$ to $\leq 10^{-4}$ & $\leq$ ERPG-3 & $\leq$ ERPG-2 \\
\hline
\end{tabular}

ERPG = Emergency Response Planning Guideline

PEL-TWA $=$ permissible exposure limit - time-weighted average 


\section{RPP-5554 REV 0}

Additional criteria to guide control decisions are the following:

- Control preferences are as follows:

- Controls that prevent the accident versus those that mitigate its consequences

- Passive engineered versus active engineered controls

- Engineered controls versus administrative controls.

- Controls providing significant defense-in-depth are classified as safety SSCs or are elevated to a TSR control

- TSR controls are not developed for postulated accidents resulting in only environmental consequences

- SSCs are not classified safety-class or safety-significant solely for preventing or mitigating postulated accidents resulting in environmental consequences.

Other criteria that are important considerations in control decisions are listed below:

- Control reliability, availability, and maintainability

- Control effects on facility workers (i.e., increased radiation doses or toxicological exposures - ALARA issues)

- Control optimization and integration

- Control cost/benefit

- Control human factors impacts

- Control impacts on TWRS mission 


\section{CONTROL DECISION RECORD}

\section{HAZARD/ACCIDENT TITLE:}

Structures, Systems, and Components (SSCs)

\begin{tabular}{|l|l|l|l|l|}
\hline \multirow{2}{*}{$\begin{array}{c}\text { Structures, Systems, } \\
\text { and Components }\end{array}$} & \multicolumn{2}{|c|}{ Classification } & \multirow{2}{*}{ Safety Function } & \multirow{2}{*}{ Comments } \\
\cline { 2 - 5 } & $\mathrm{SC}^{*}$ & SS* & & \\
\hline & & & & \\
\hline & & & & \\
\hline & & & & \\
\hline
\end{tabular}

*SC is safety class

SS is safety significant

Technical Safety Requirements (TSRs)

\begin{tabular}{|l|l|l|}
\hline Control & Safety Function & Comments \\
\hline & & \\
\hline & & \\
\hline & & \\
\hline
\end{tabular}

Defense-in Depth Controls

\begin{tabular}{|l|l|l|}
\hline Control & Safety Function & Comments \\
\hline & & \\
\hline & & \\
\hline & & \\
\hline
\end{tabular}


RPP-5554 REV 0

This page intentionally left blank.

Att 3-6 
RPP-5554 REV 0

ATTACHMENT 4

NOVEMBER 16, 1999 CONTROL DECISION MEETING PRESENTATIONS

Att 4-i 
RPP-5554 REV 0

This page intentionally left blank.

Att 4-ii 
RPP-5554 REV 0

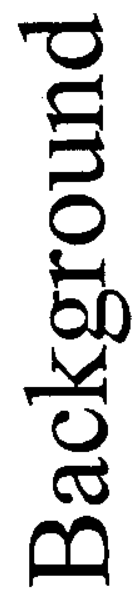

Att 4-1 


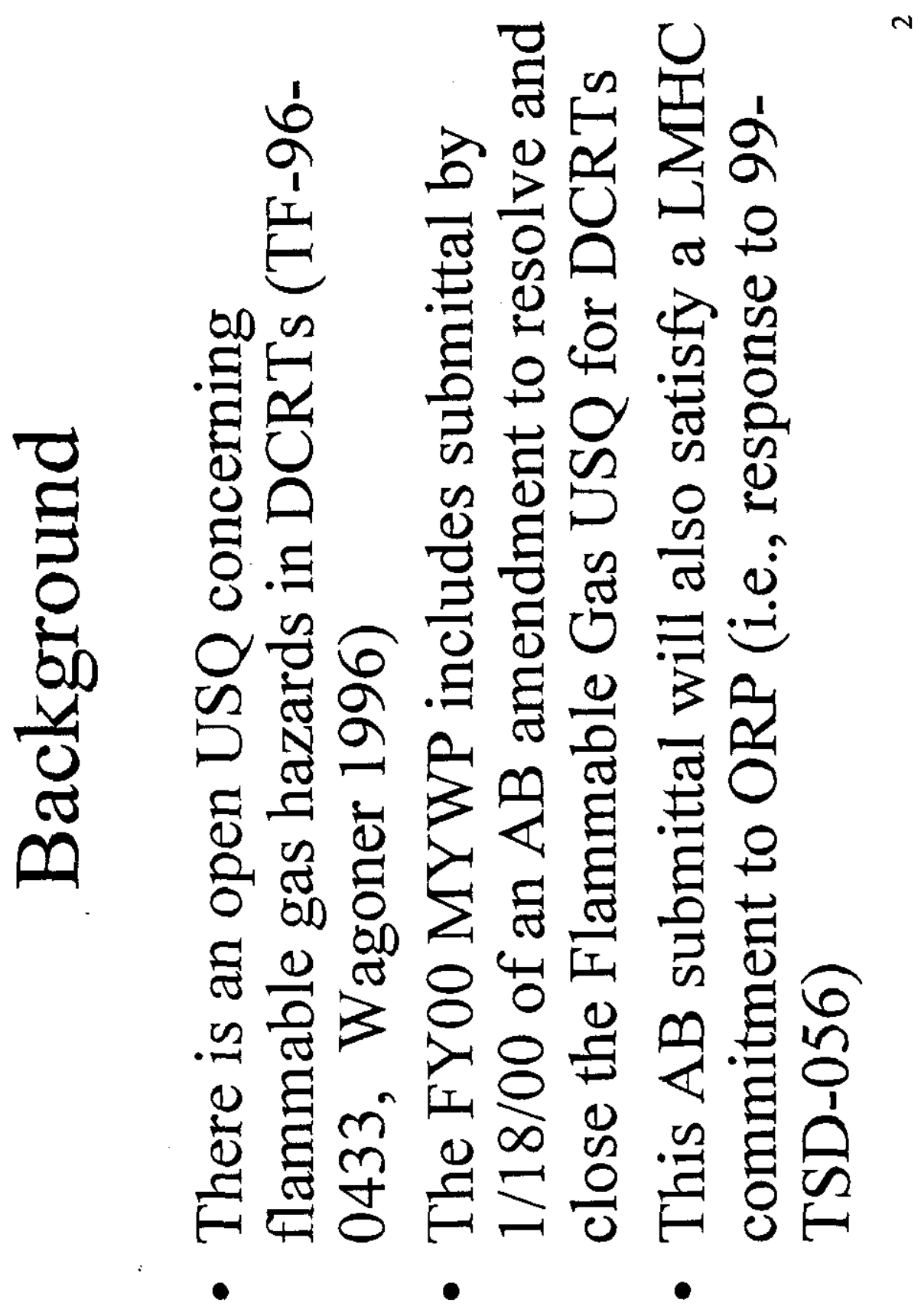


RPP-5554 REV 0

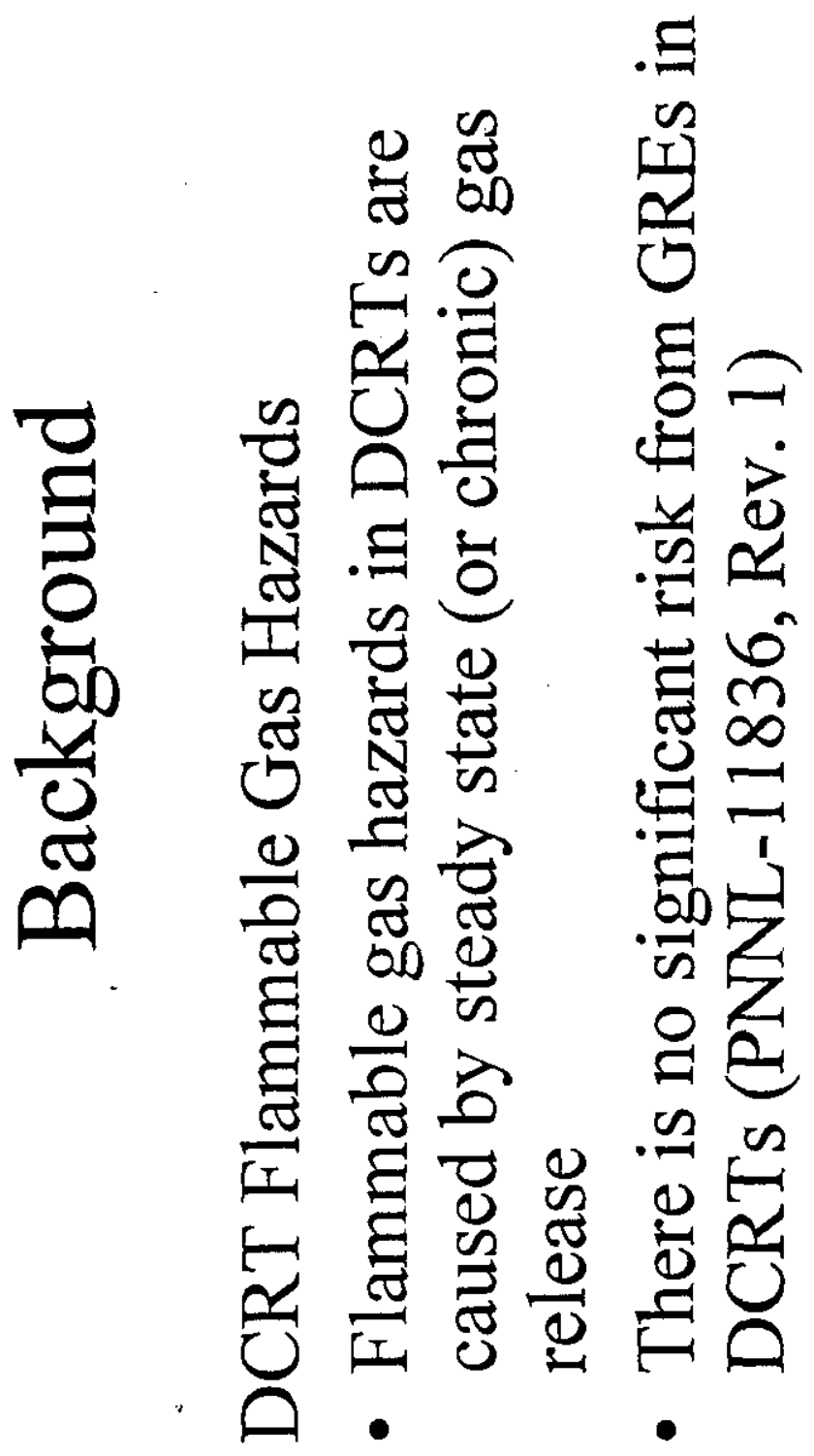

Att 4-3 
RPP-5554 REV 0

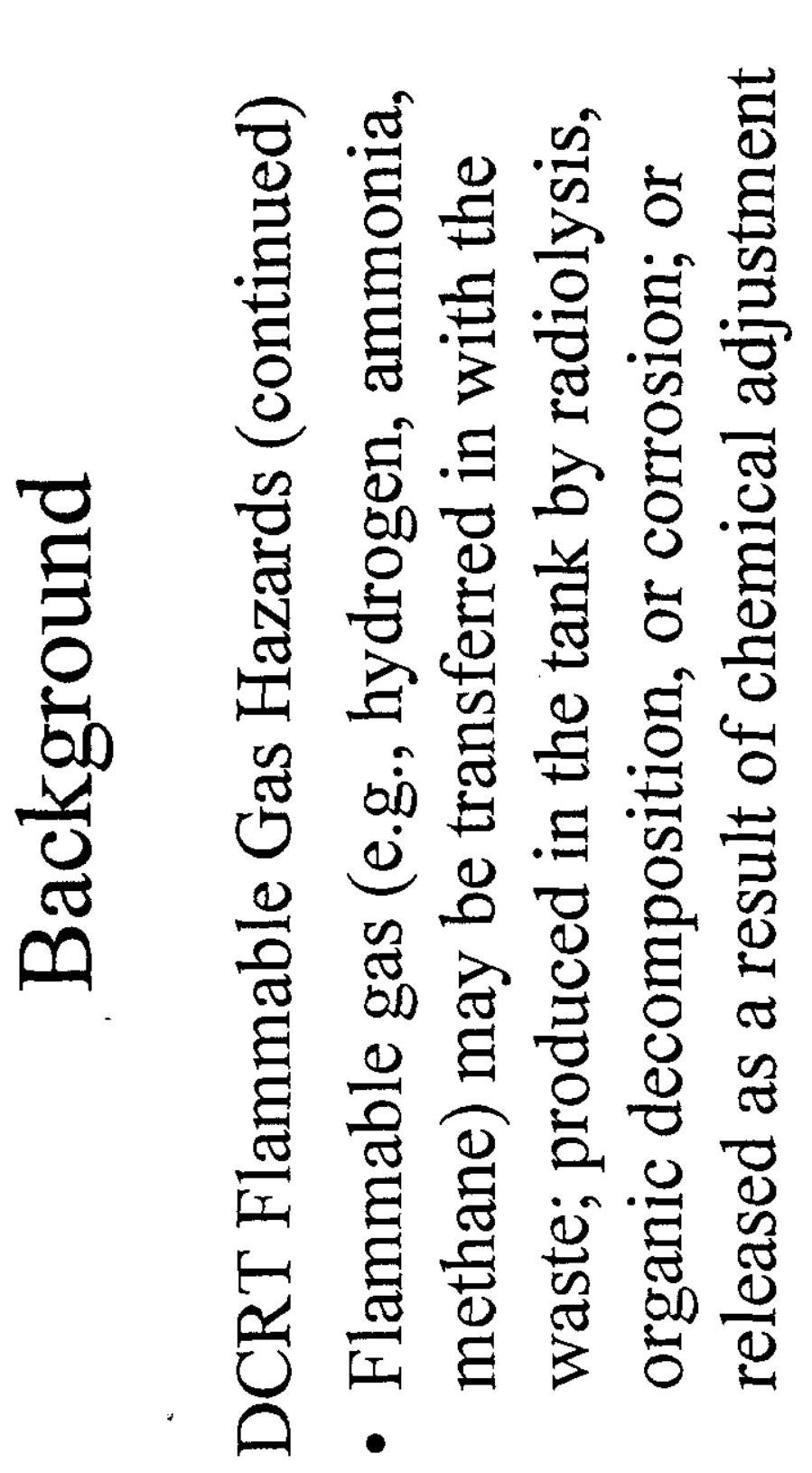


RPP-5554 REV 0

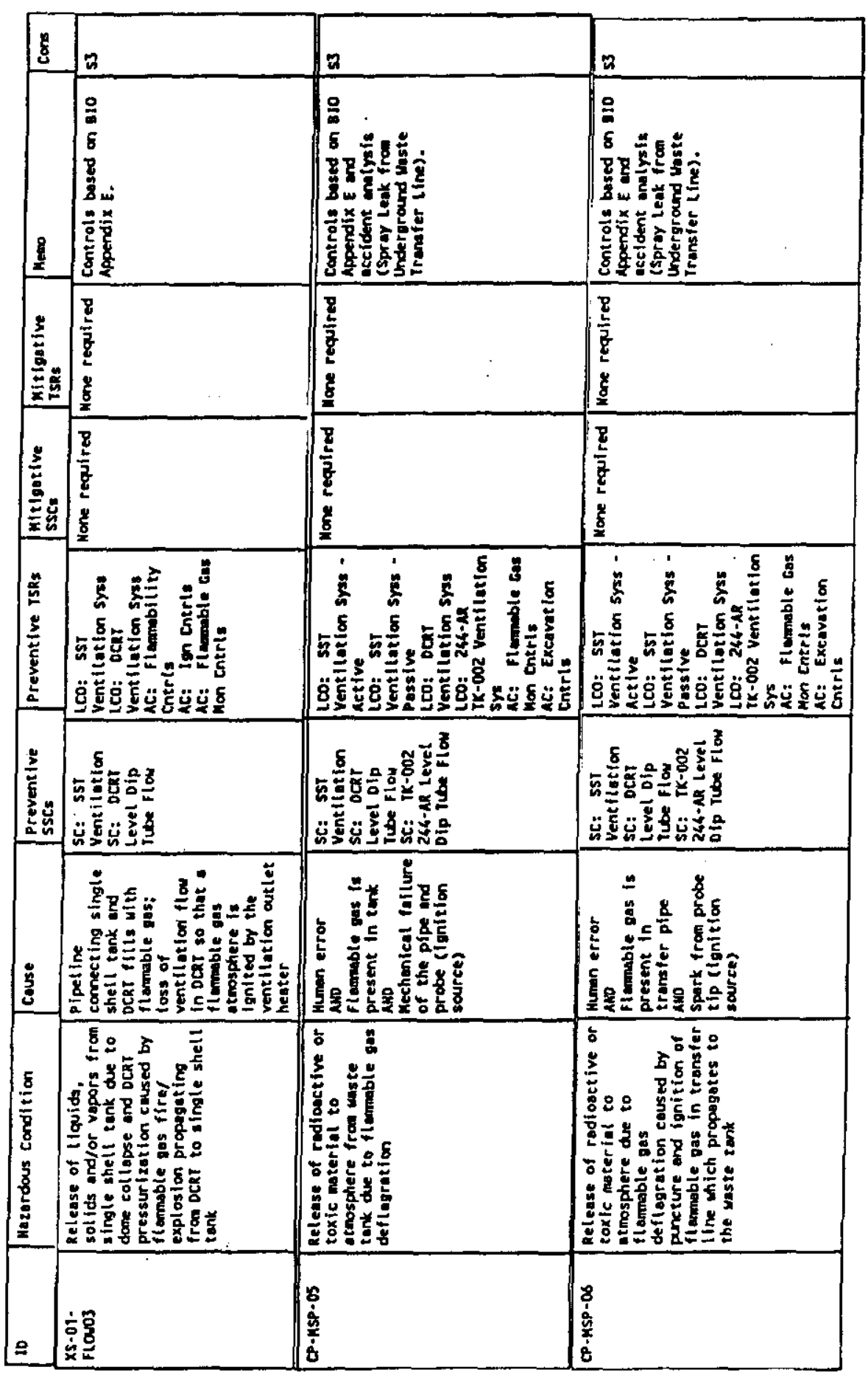


RPP-5554 REV 0

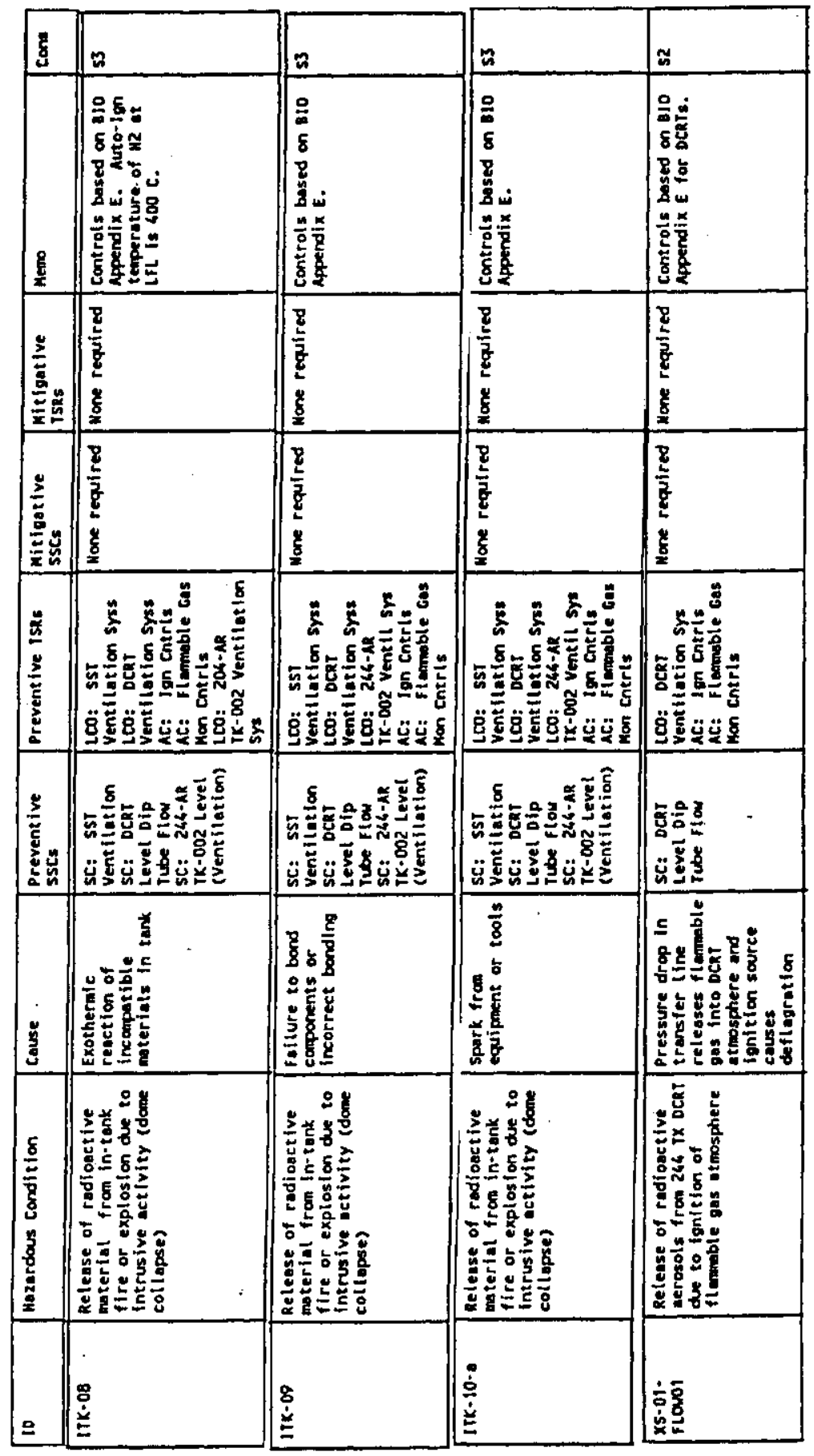


RPP-5554 REV 0

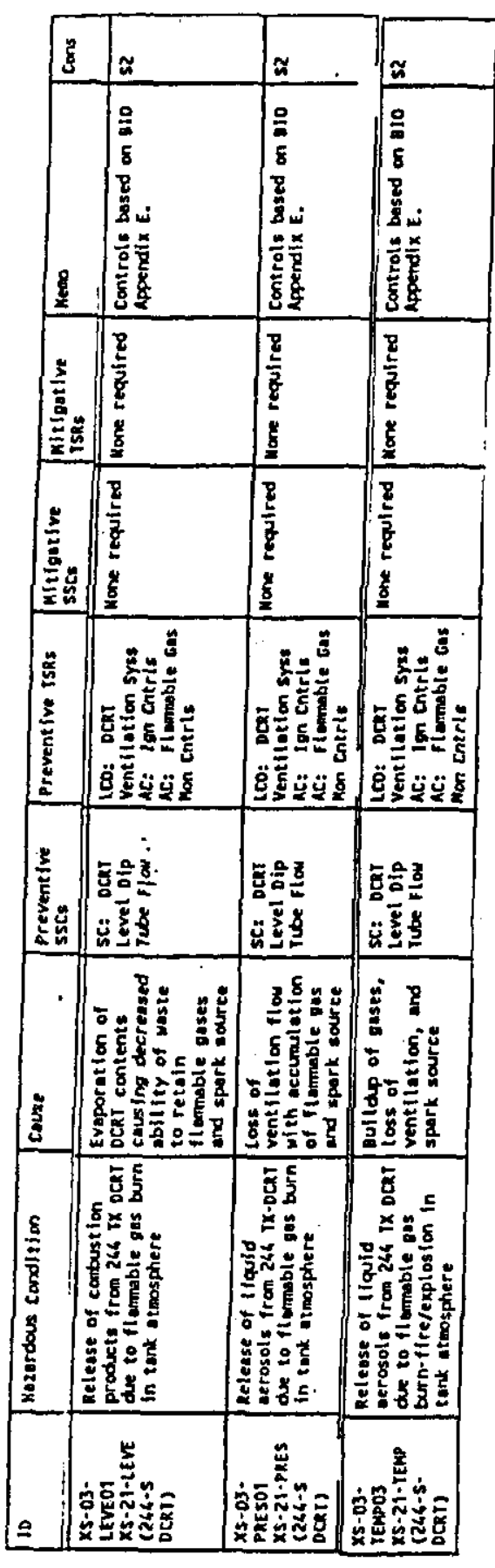


RPP-5554 REV 0

$\infty$

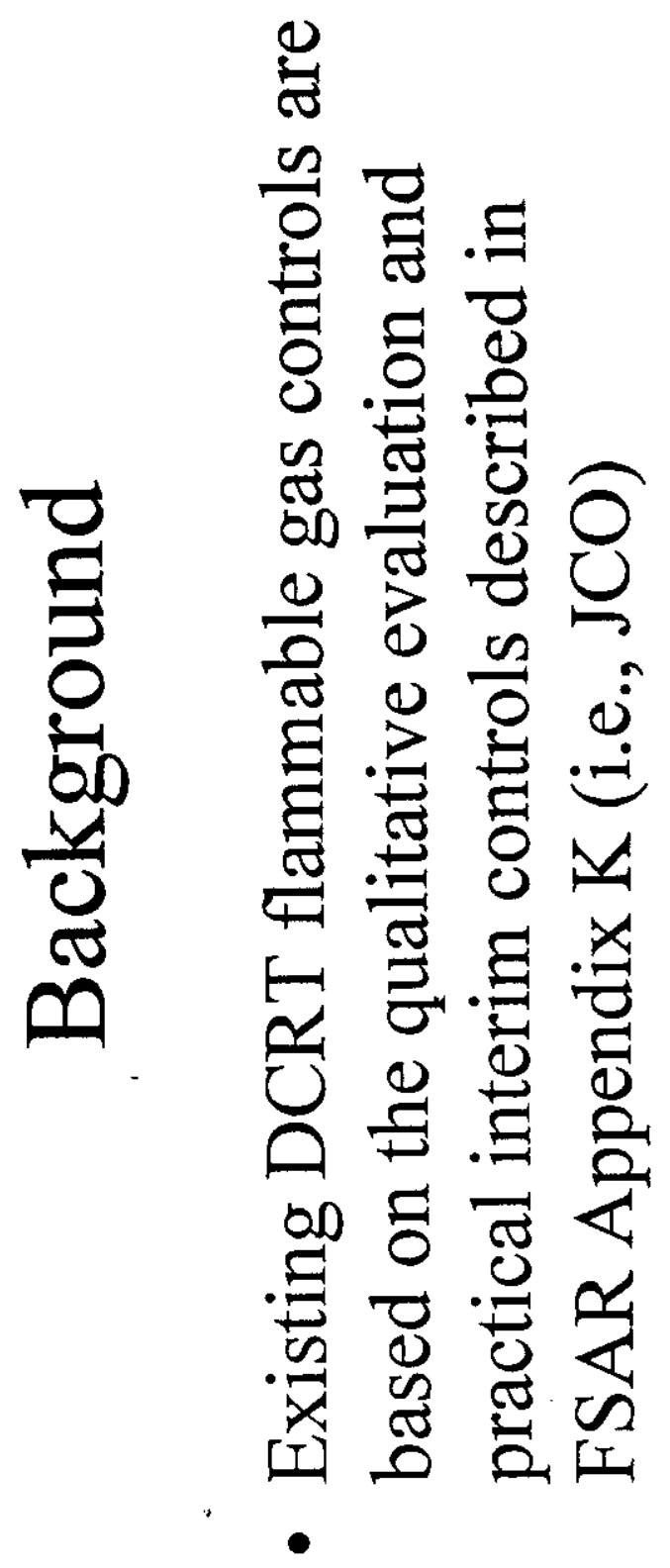

Att 4-8 
RPP-5554 REV 0

$a$

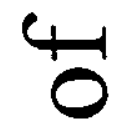

(1)

s

Ð

$\nabla$

0

光

م

응

.

을

0

is

2

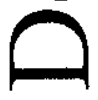




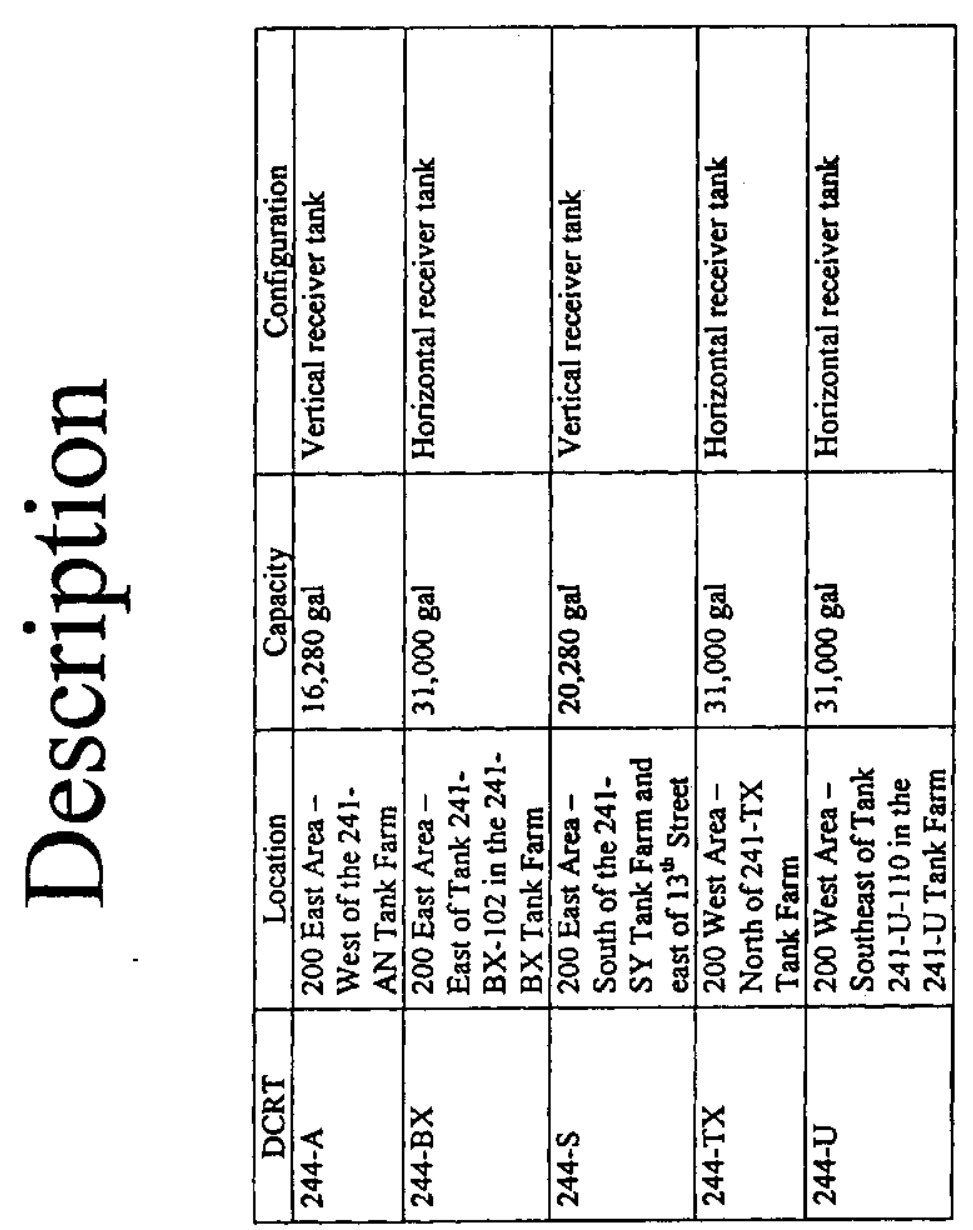


RPP-5554 REV 0

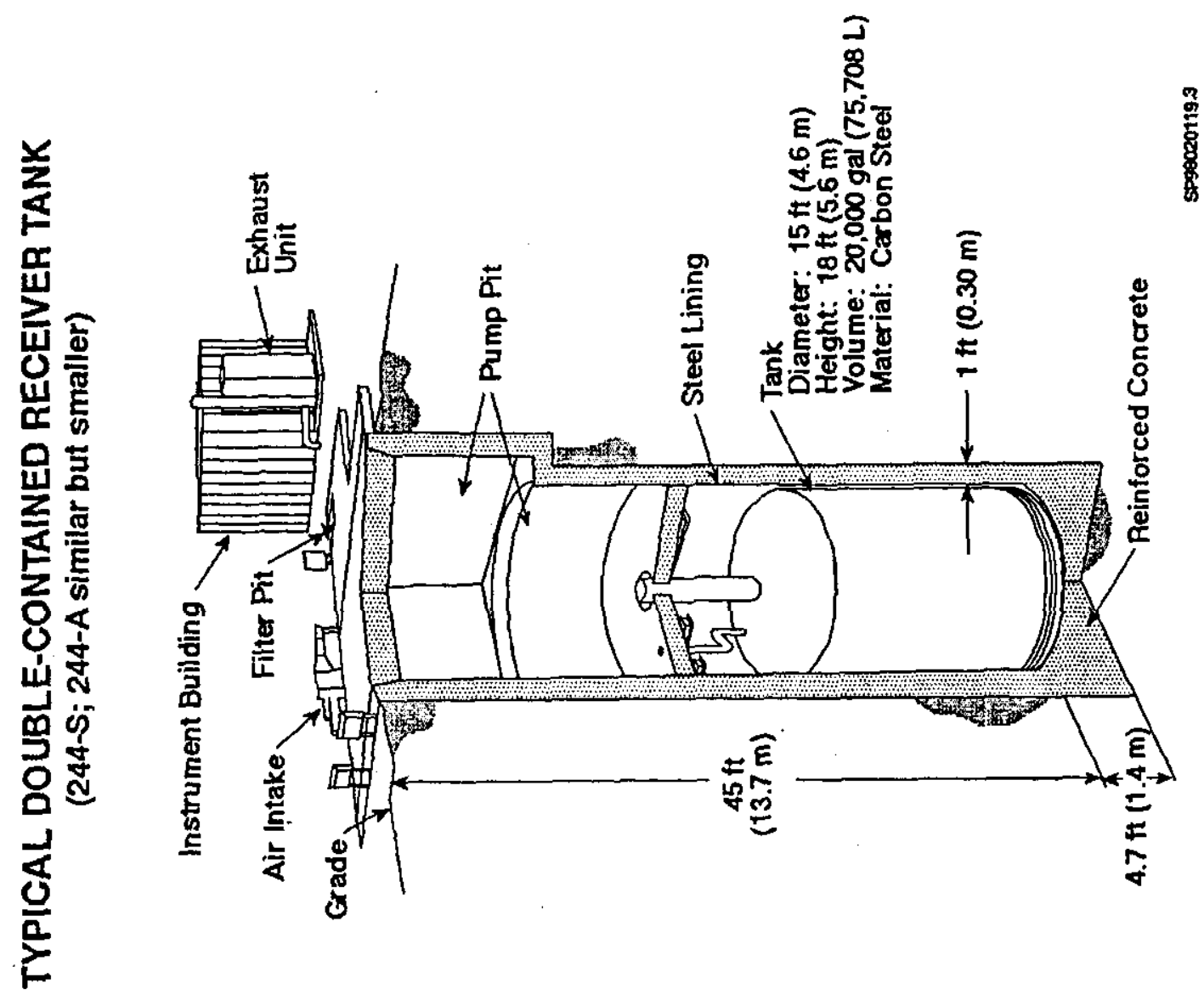


RPP-5554 REV 0

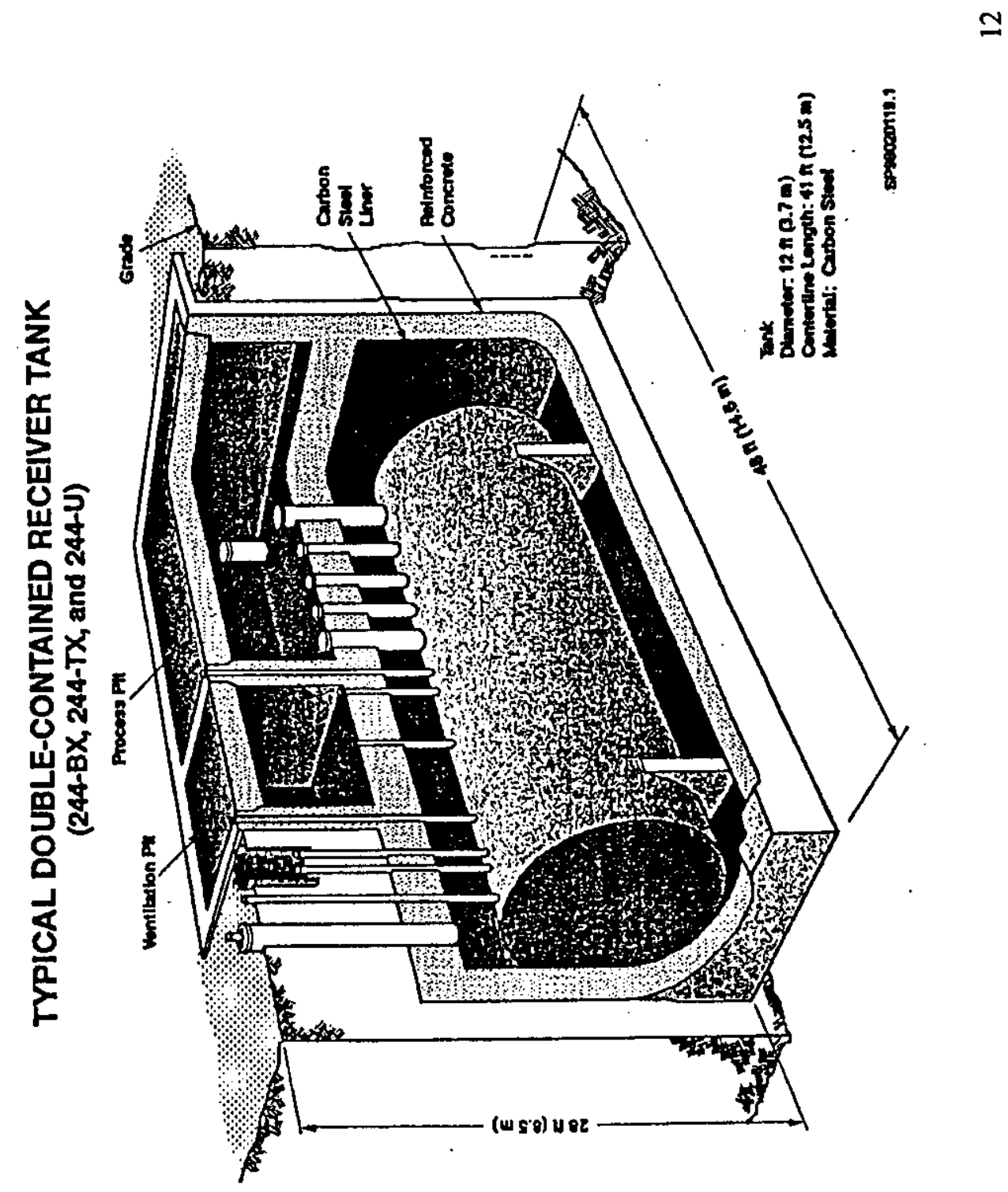


RPP-5554 REV 0

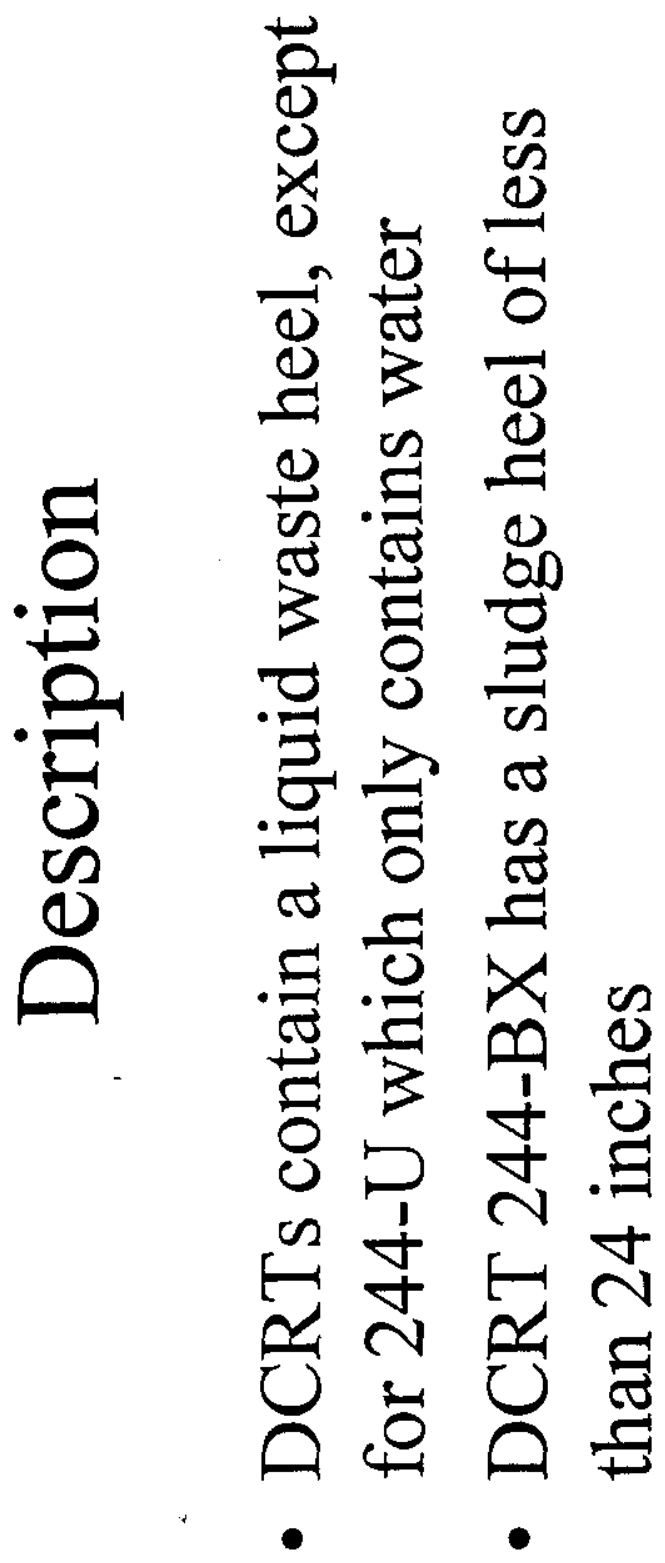

Att 4-13 
RPP-5554 REV 0

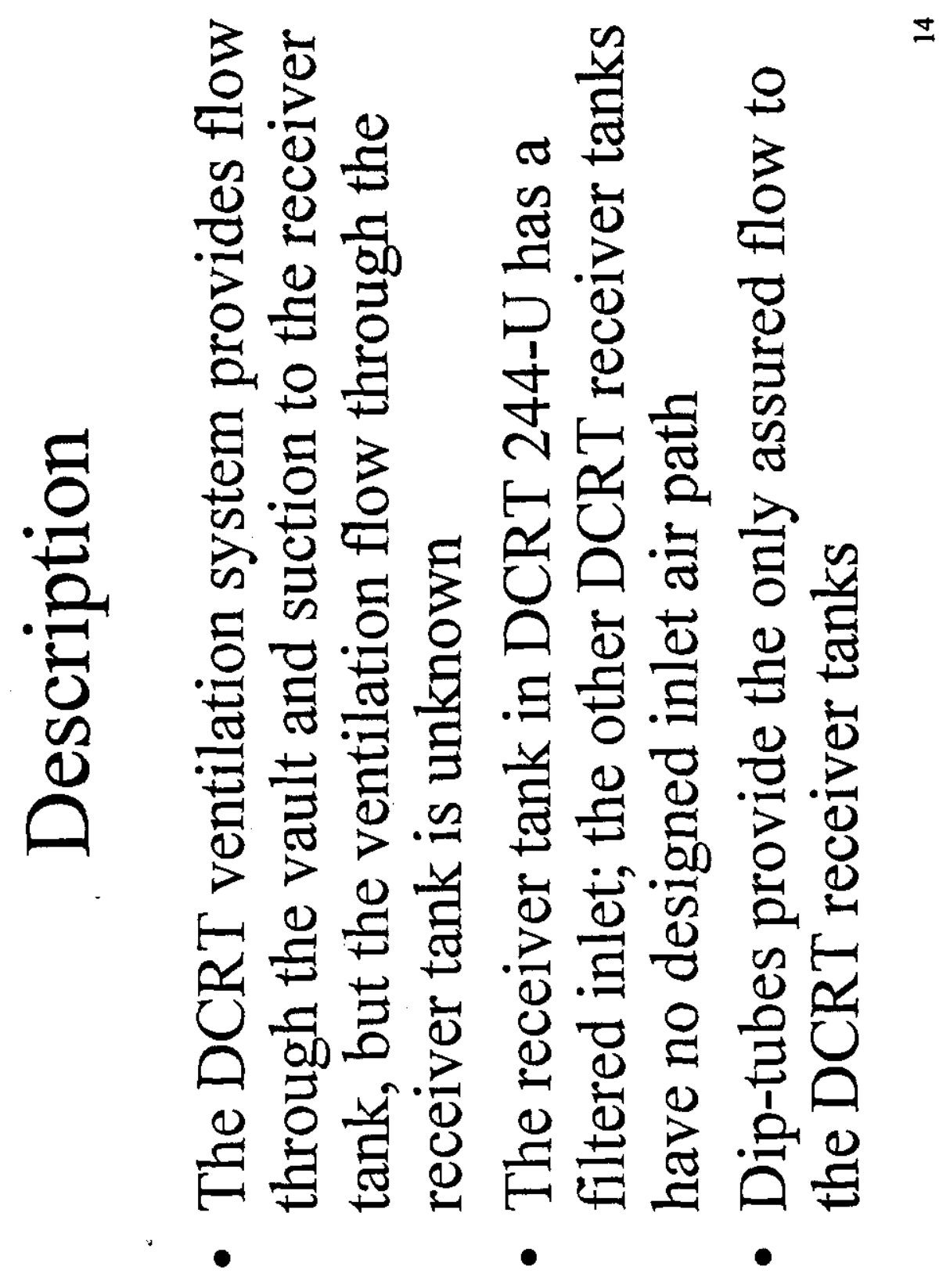


RPP-5554 REV 0

$\approx$

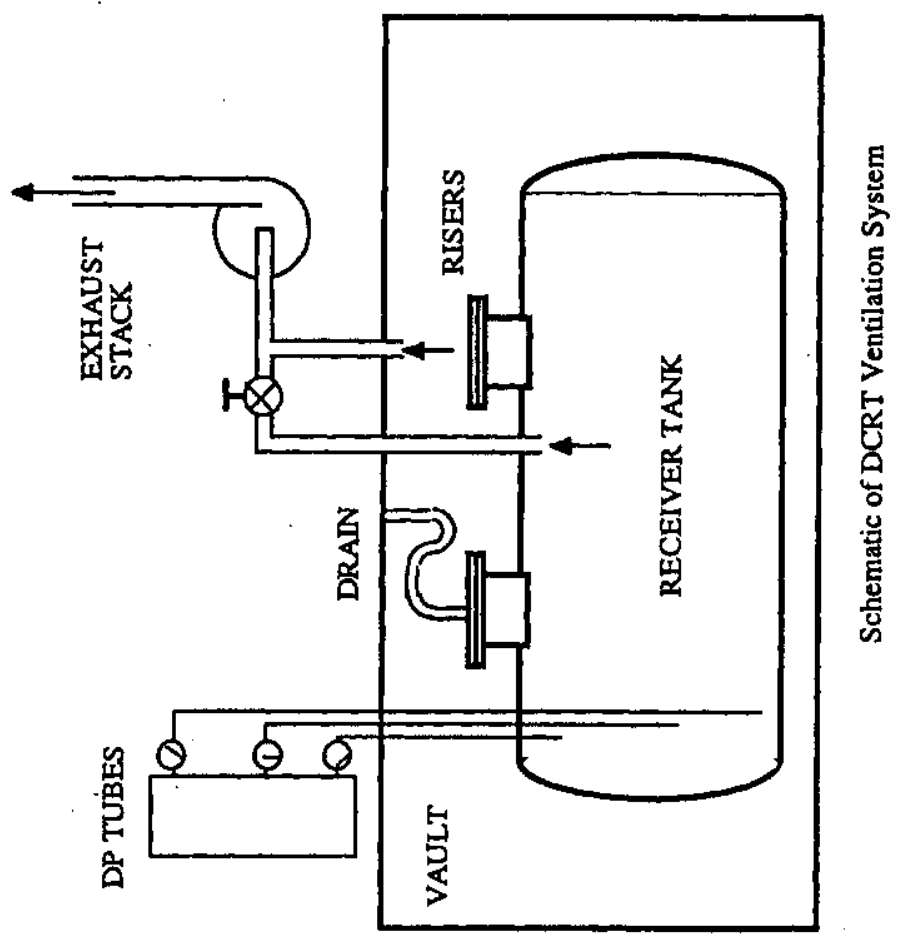

Att 4-15 


\section{RPP-5554 REV 0}

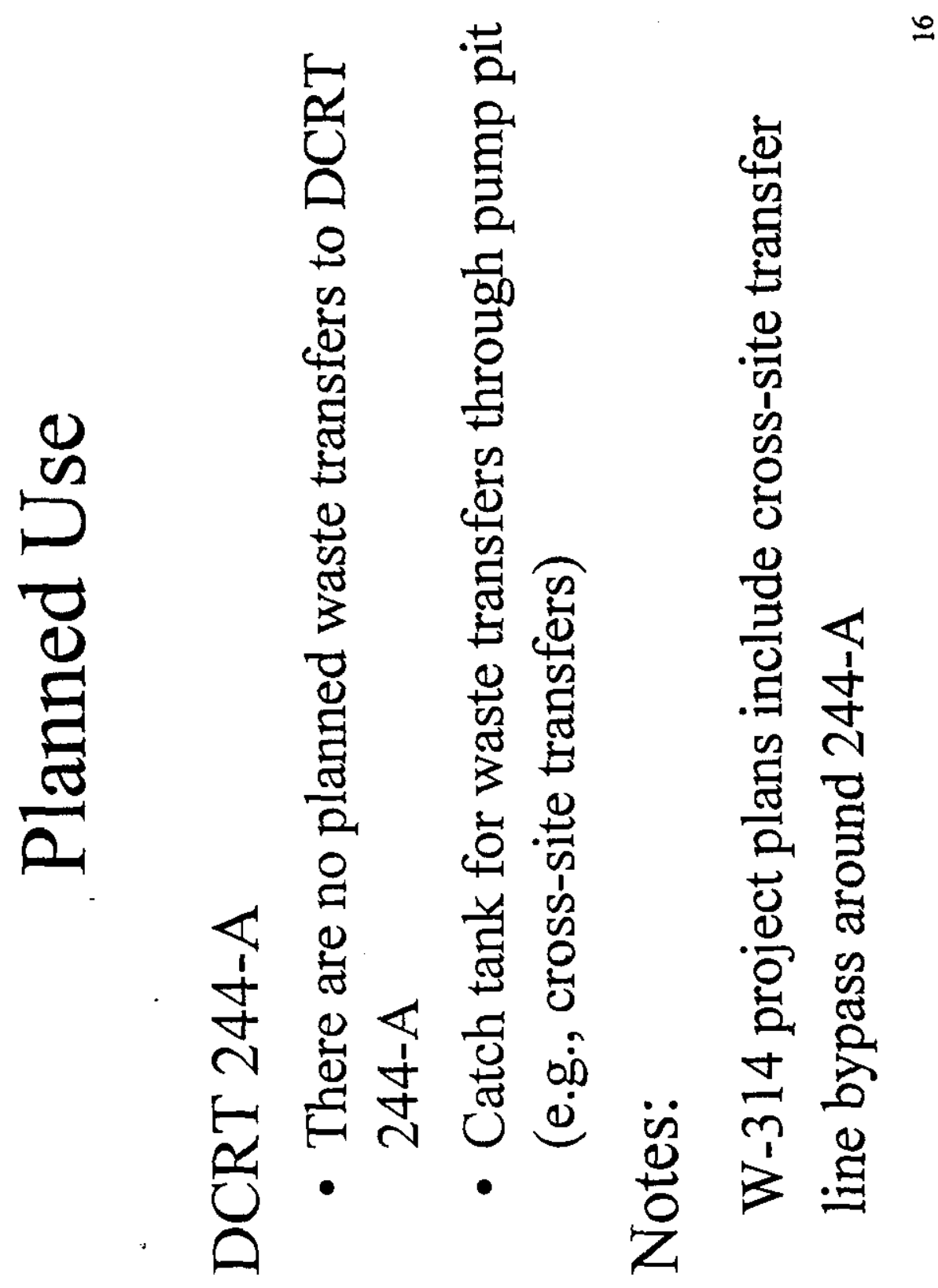


RPP-5554 REV 0

$=$

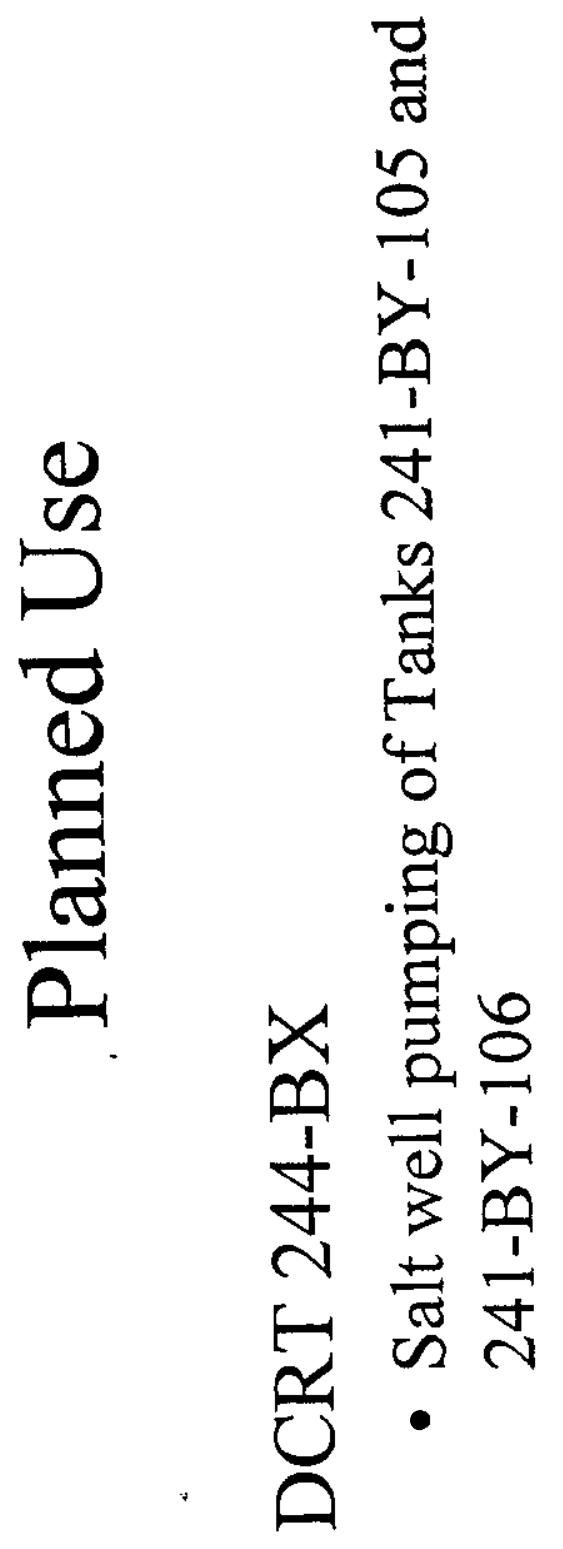

Att 4-17 


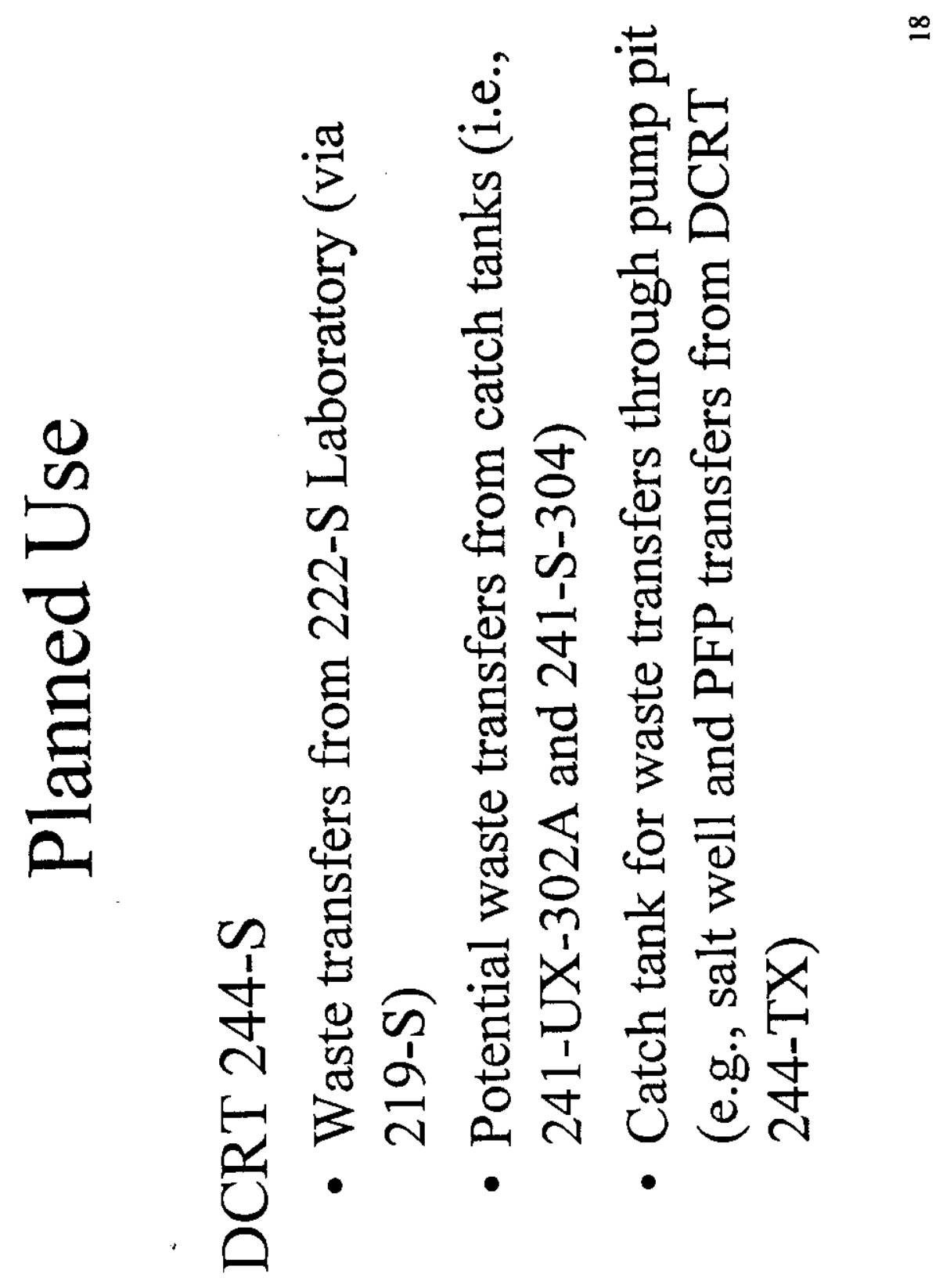




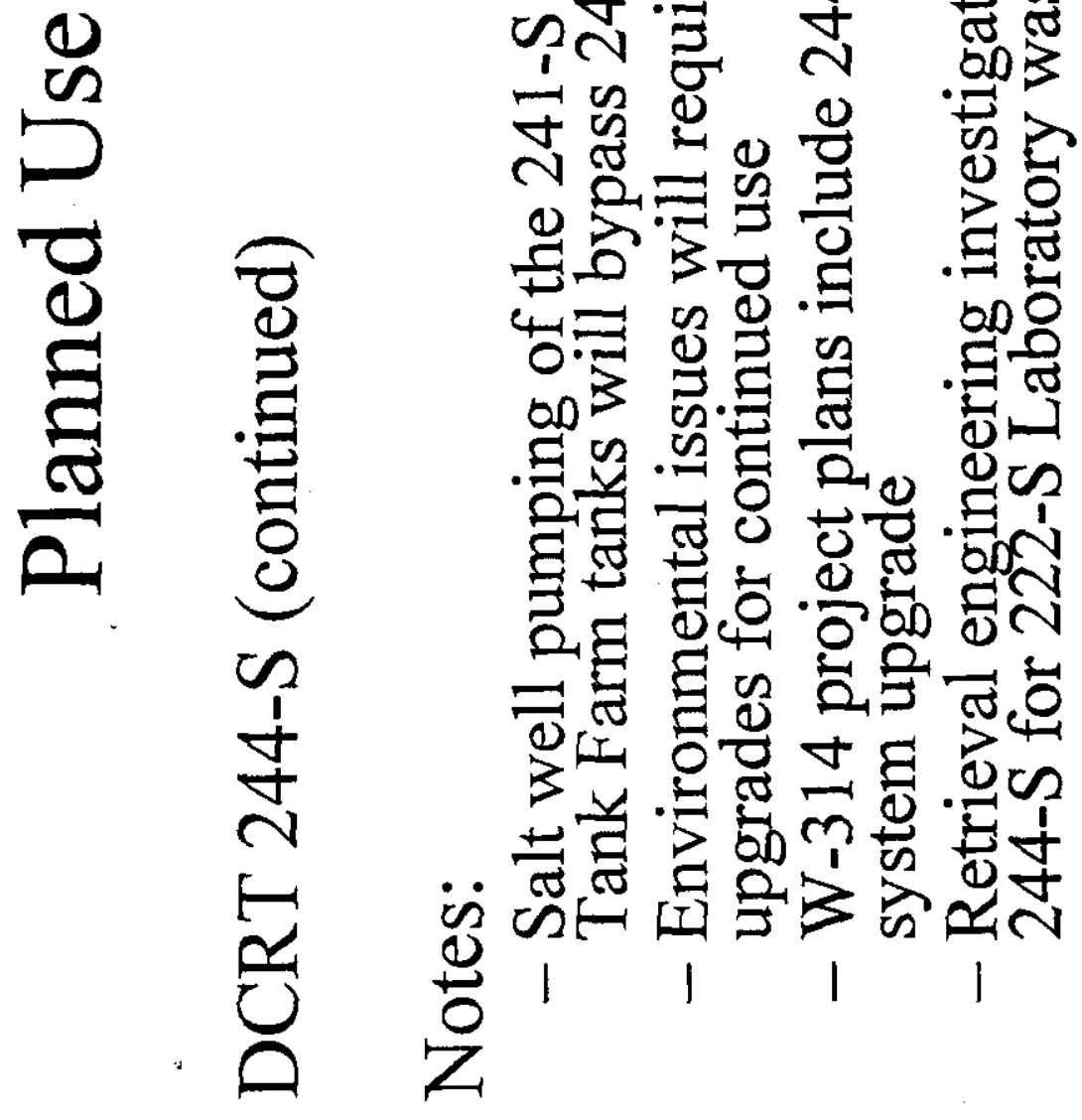


RPP-5554 REV 0

오

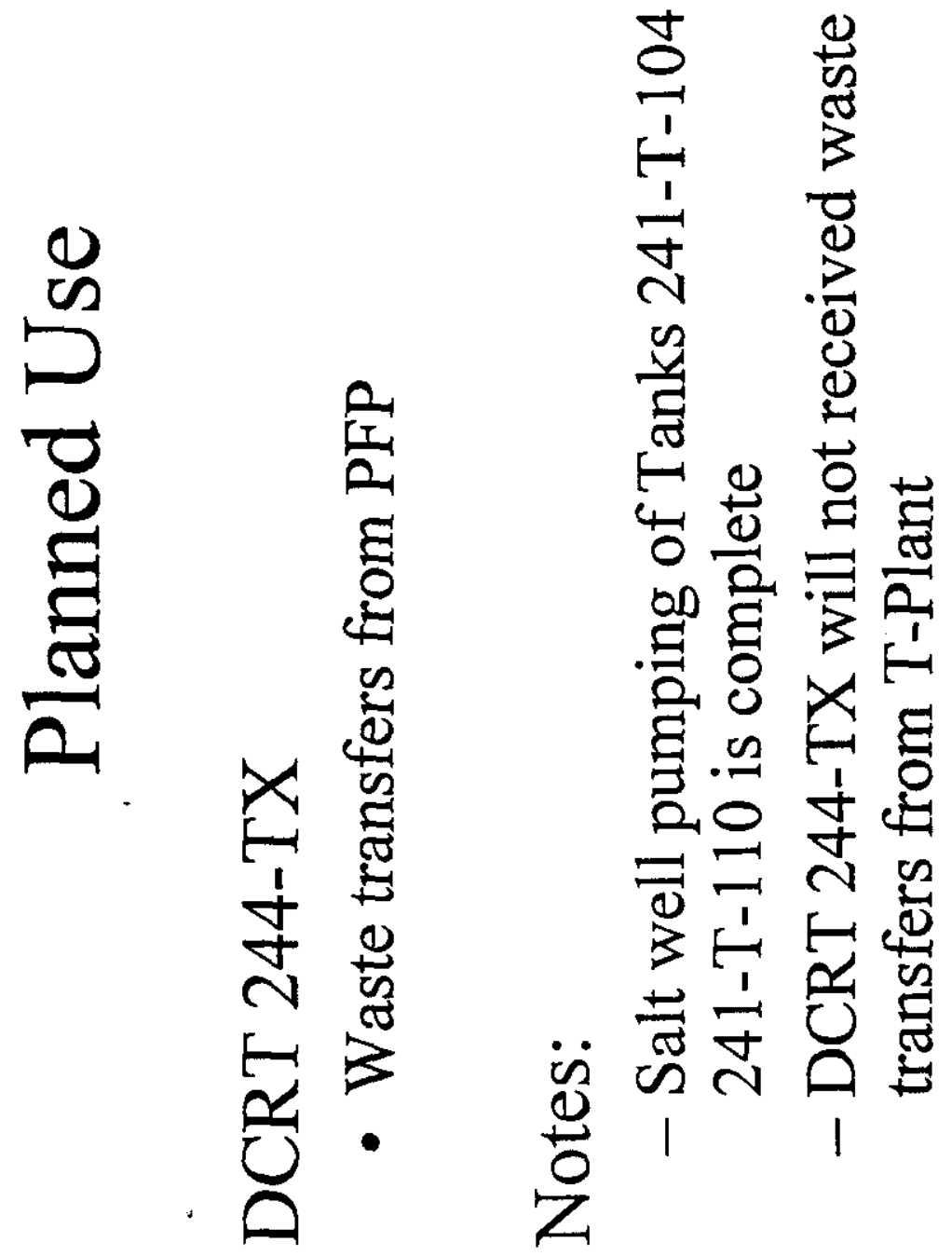

8

$\frac{9}{2}$

है 
RPP-5554 REV 0
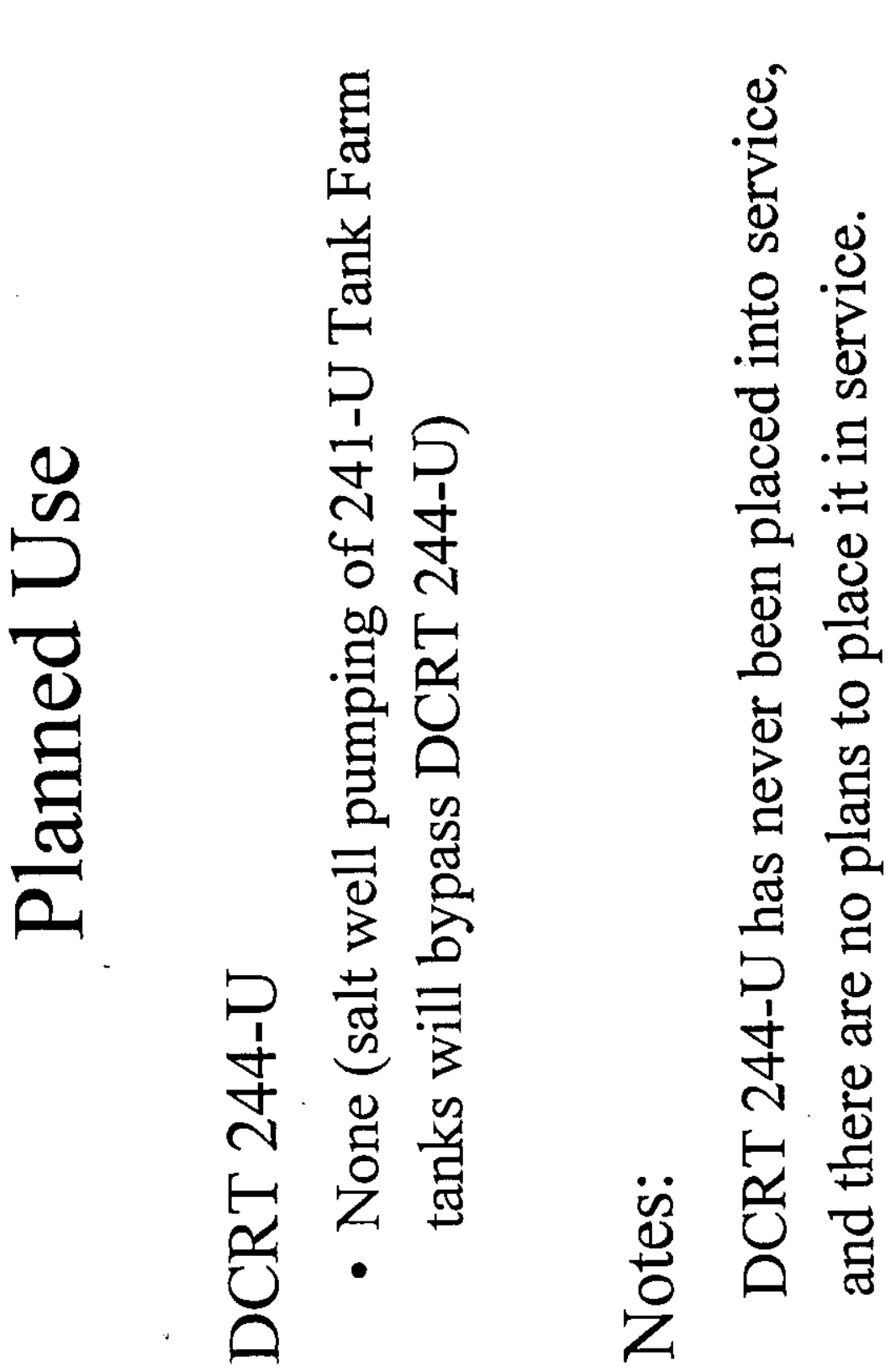
RPP-5554 REV 0

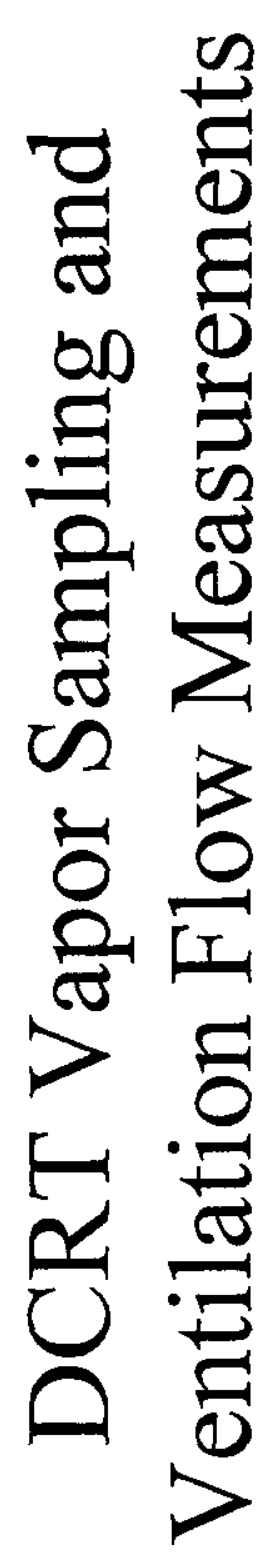

ส 
$\approx$

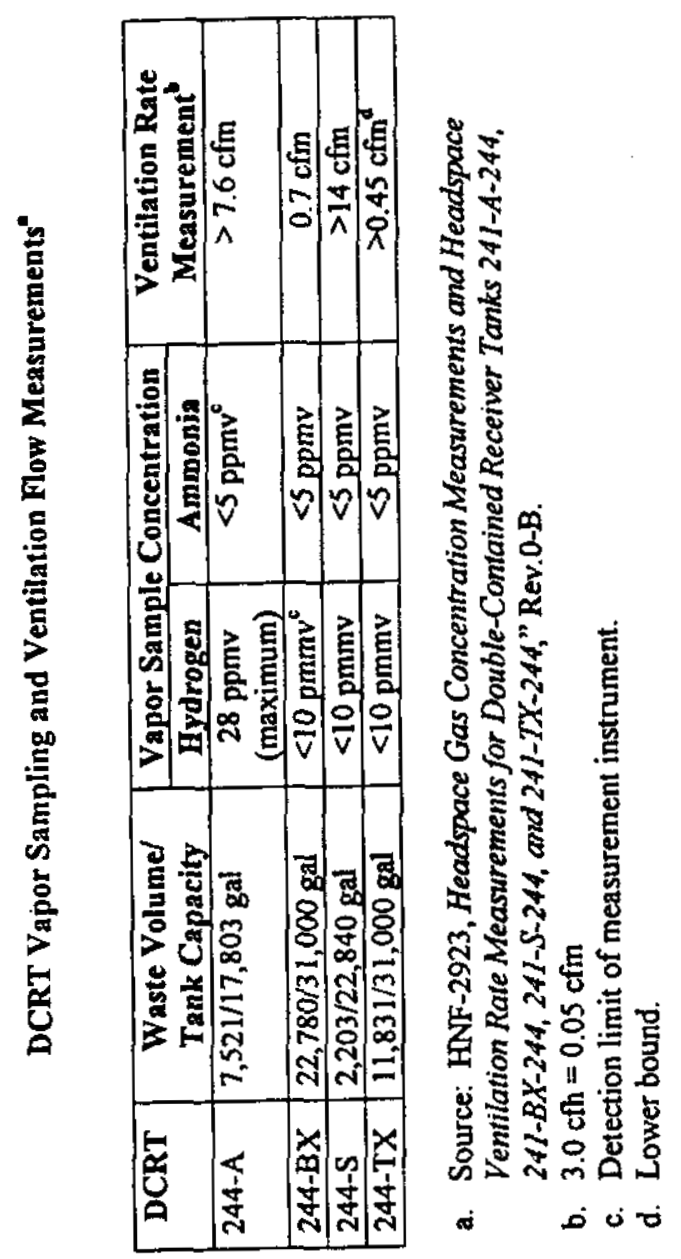


RPP-5554 REV 0

I

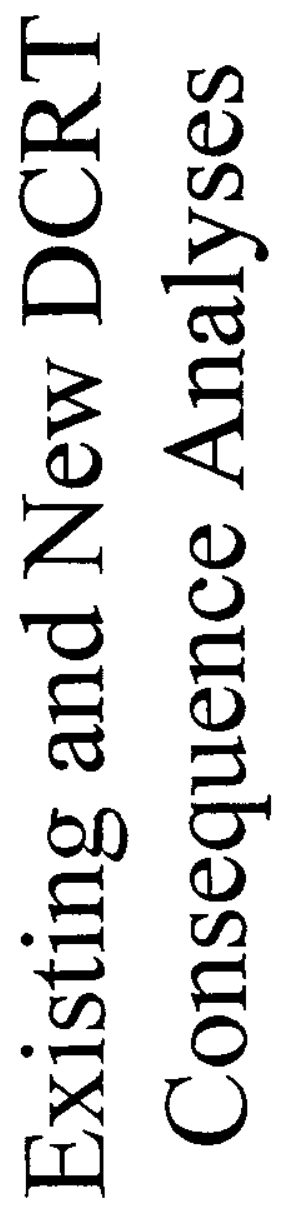

Att 4-24 
RPP-5554 REV 0

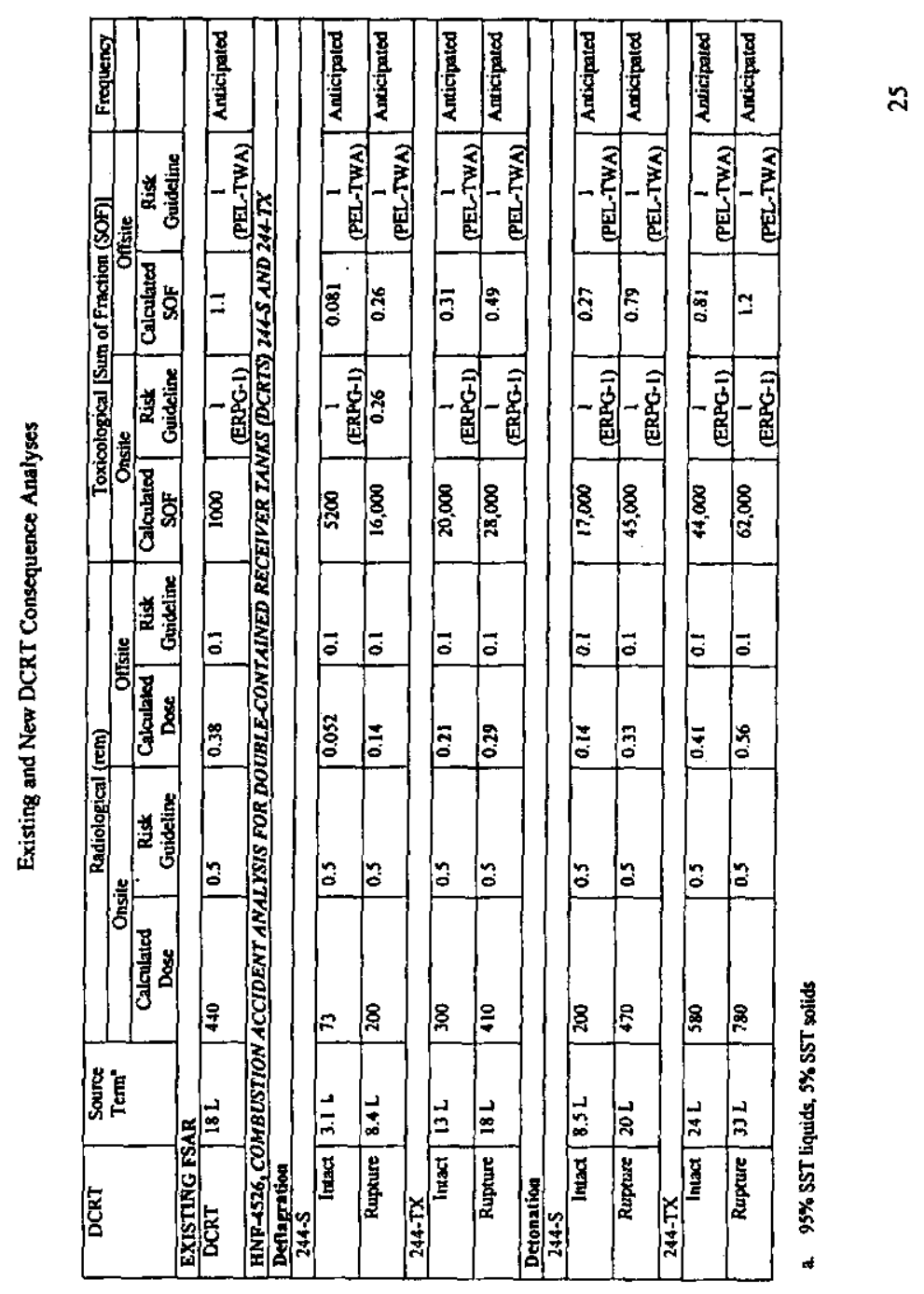

Att 4-25 
RPP-5554 REV 0

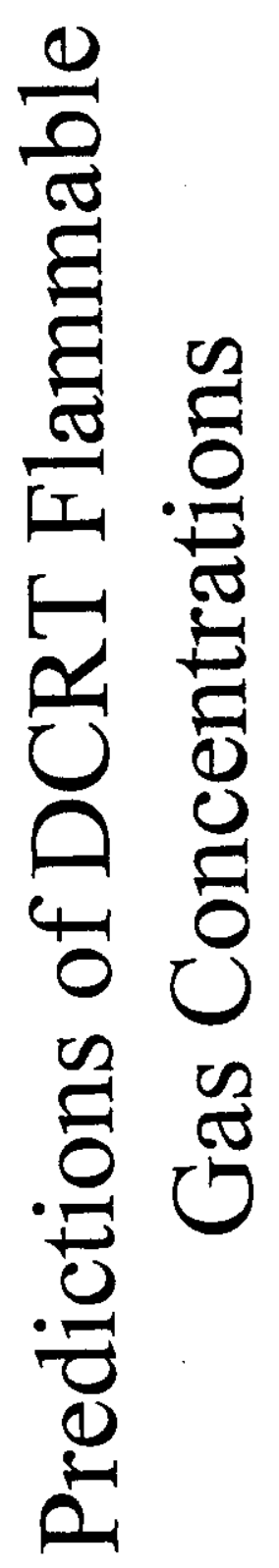


RPP-5554 REV 0

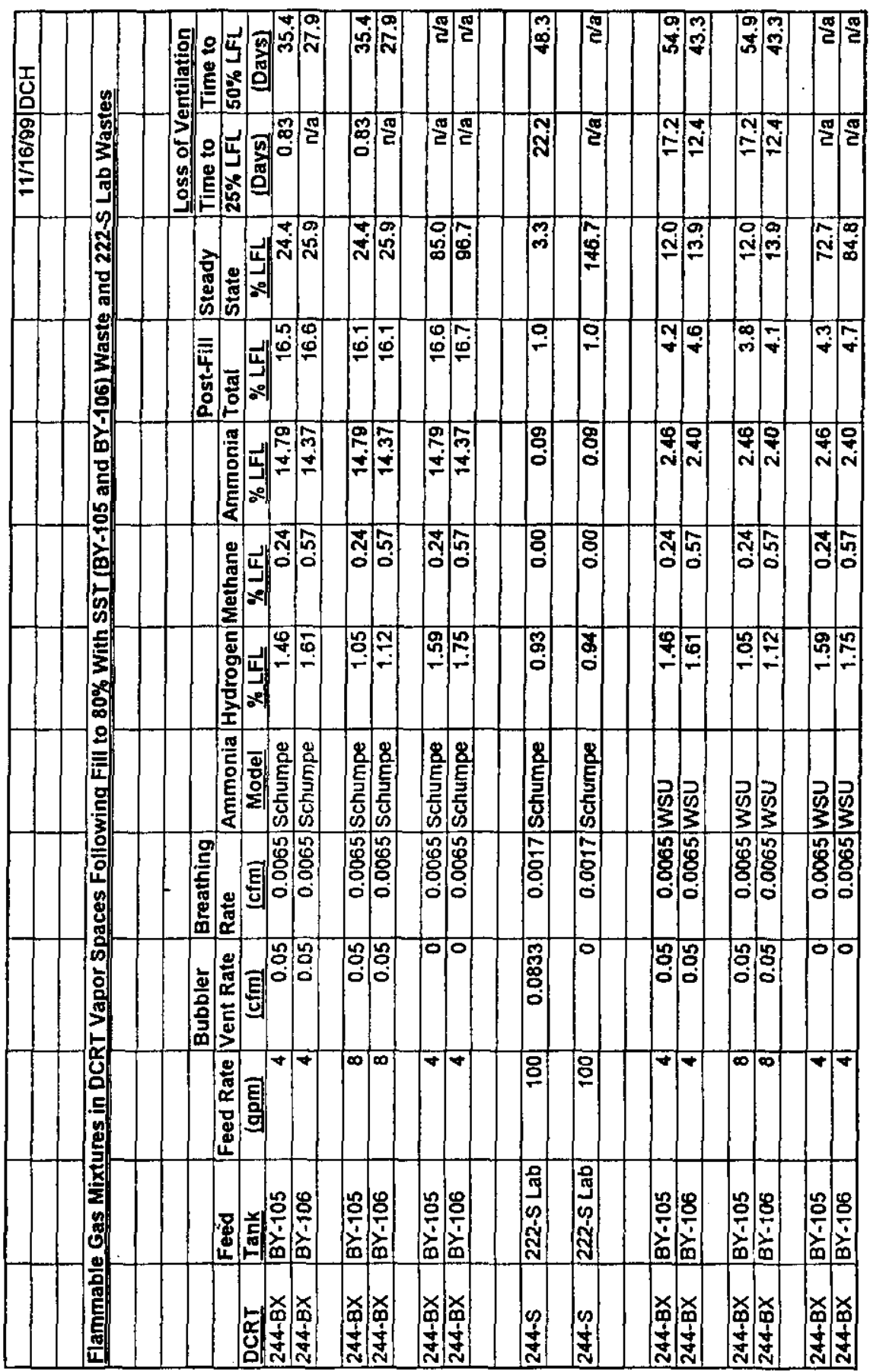




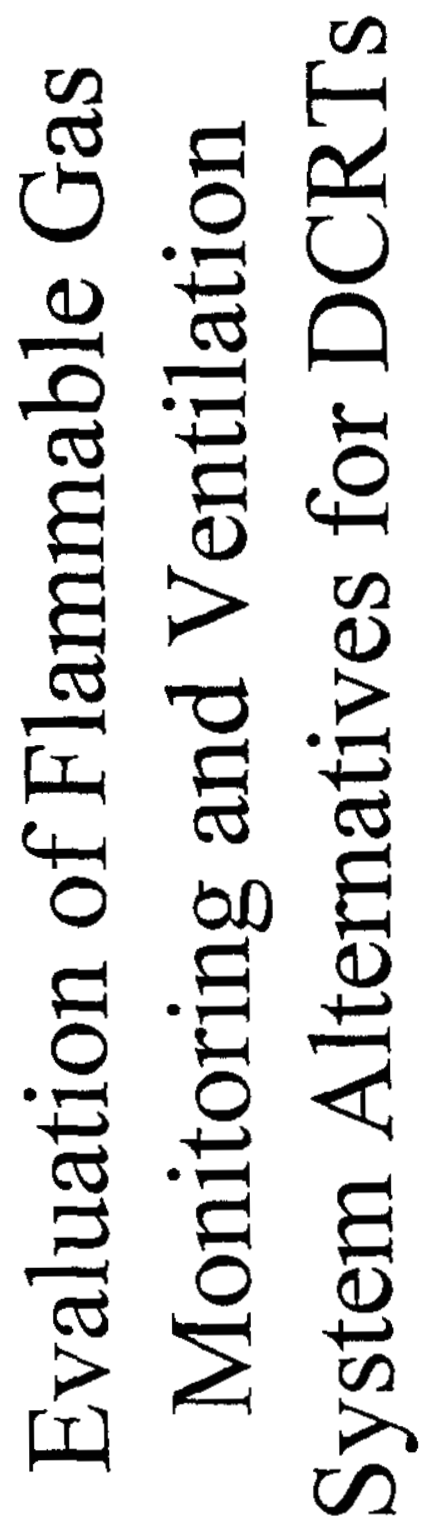


RPP-5554 REV 0

RPP-5162, Rev. 0 Page A-1

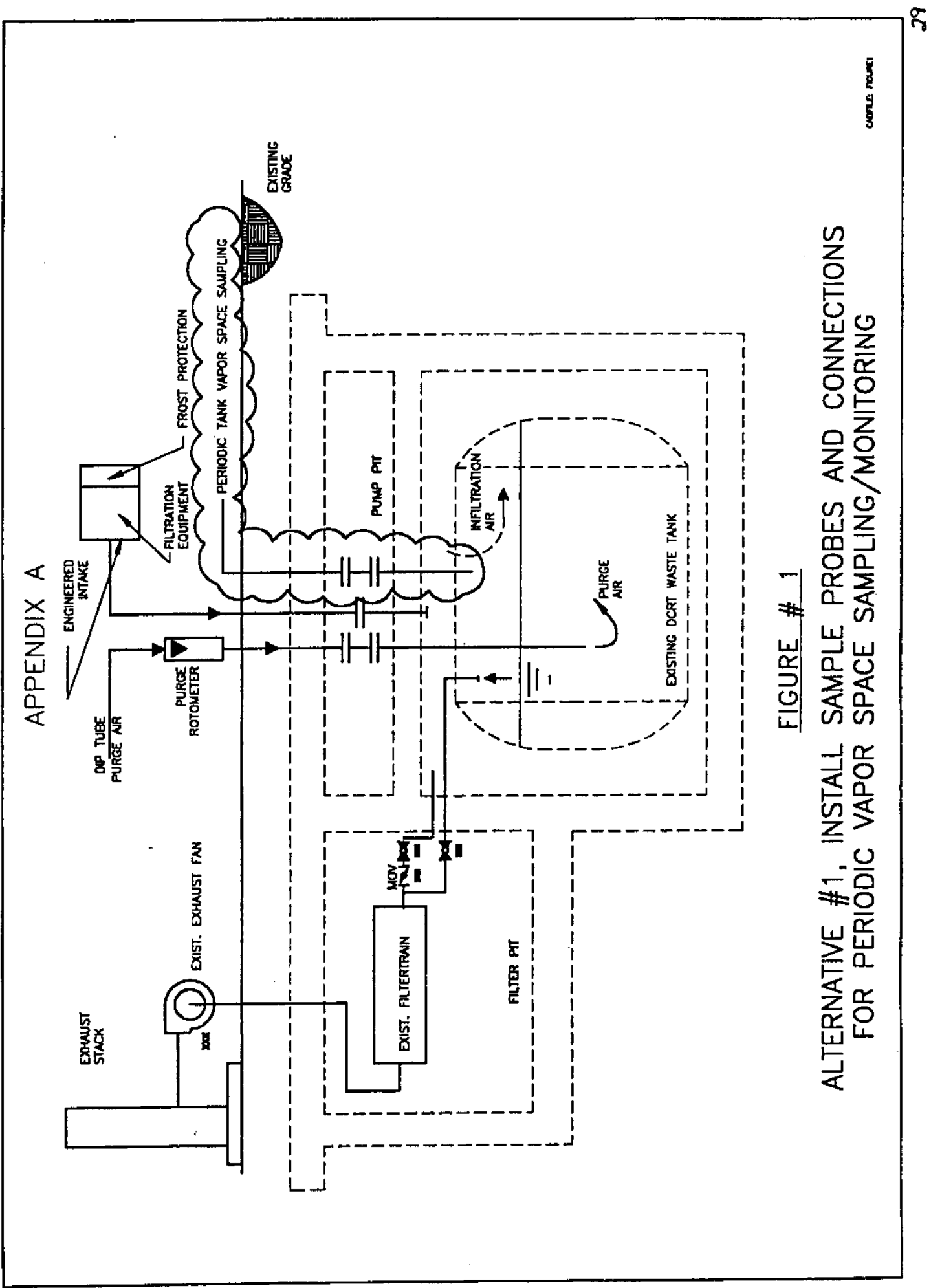


RPP-5554 REV 0

RPP-5162, Rev. 0 Page A-2

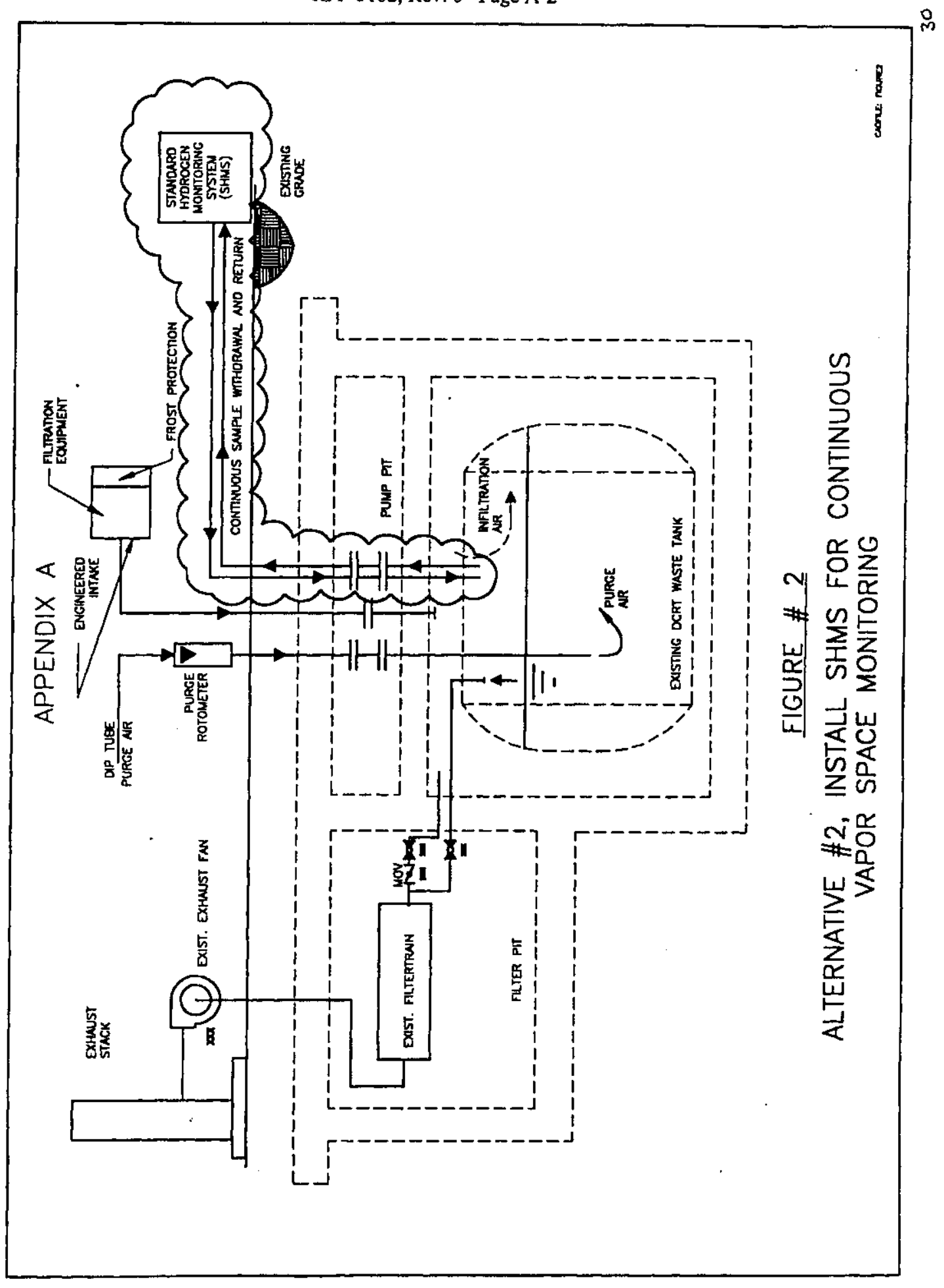


RPP-5554 REV 0

RPP-5162, Rev. 0 Page A-3

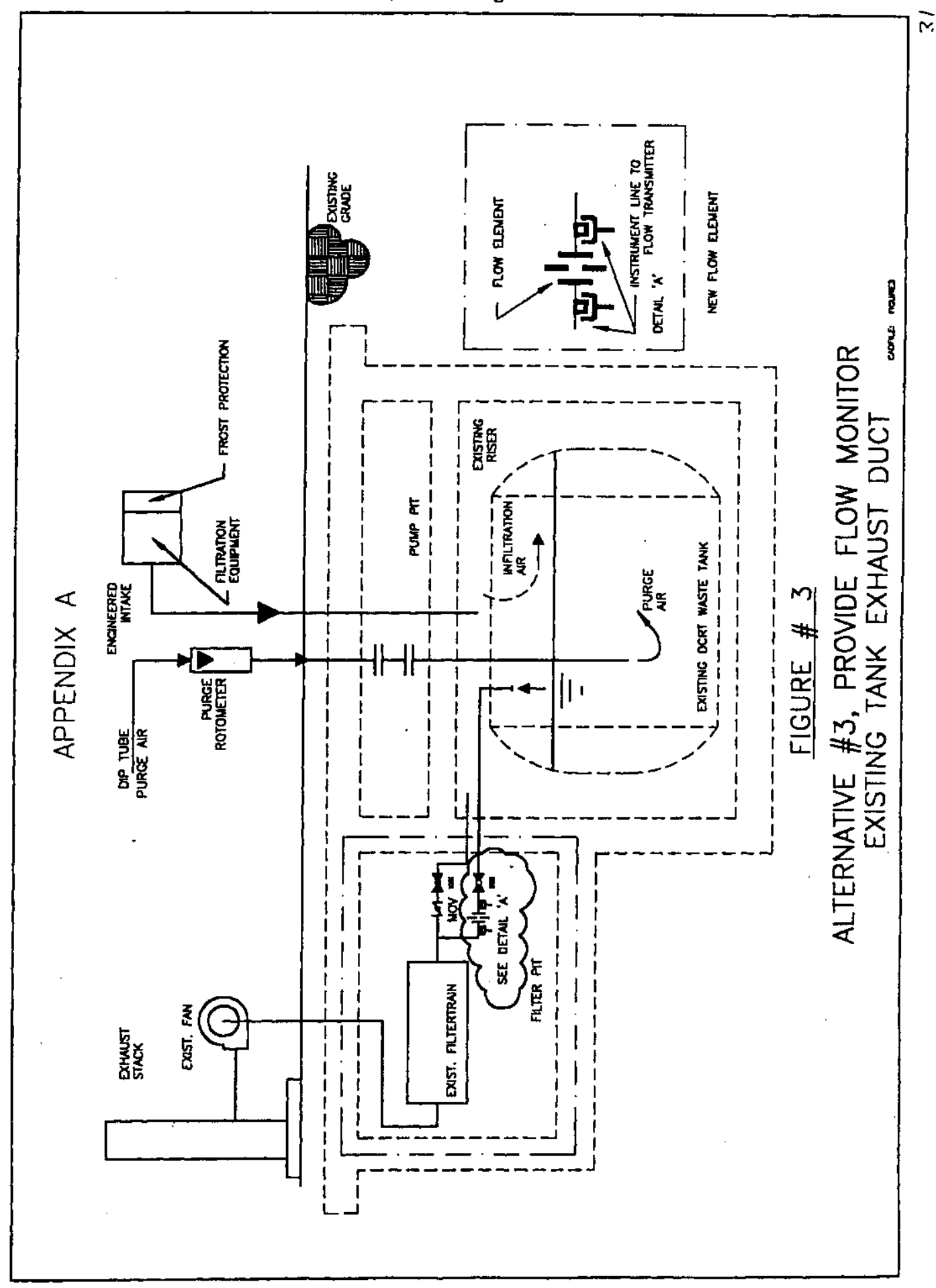


RPP-5554 REV 0

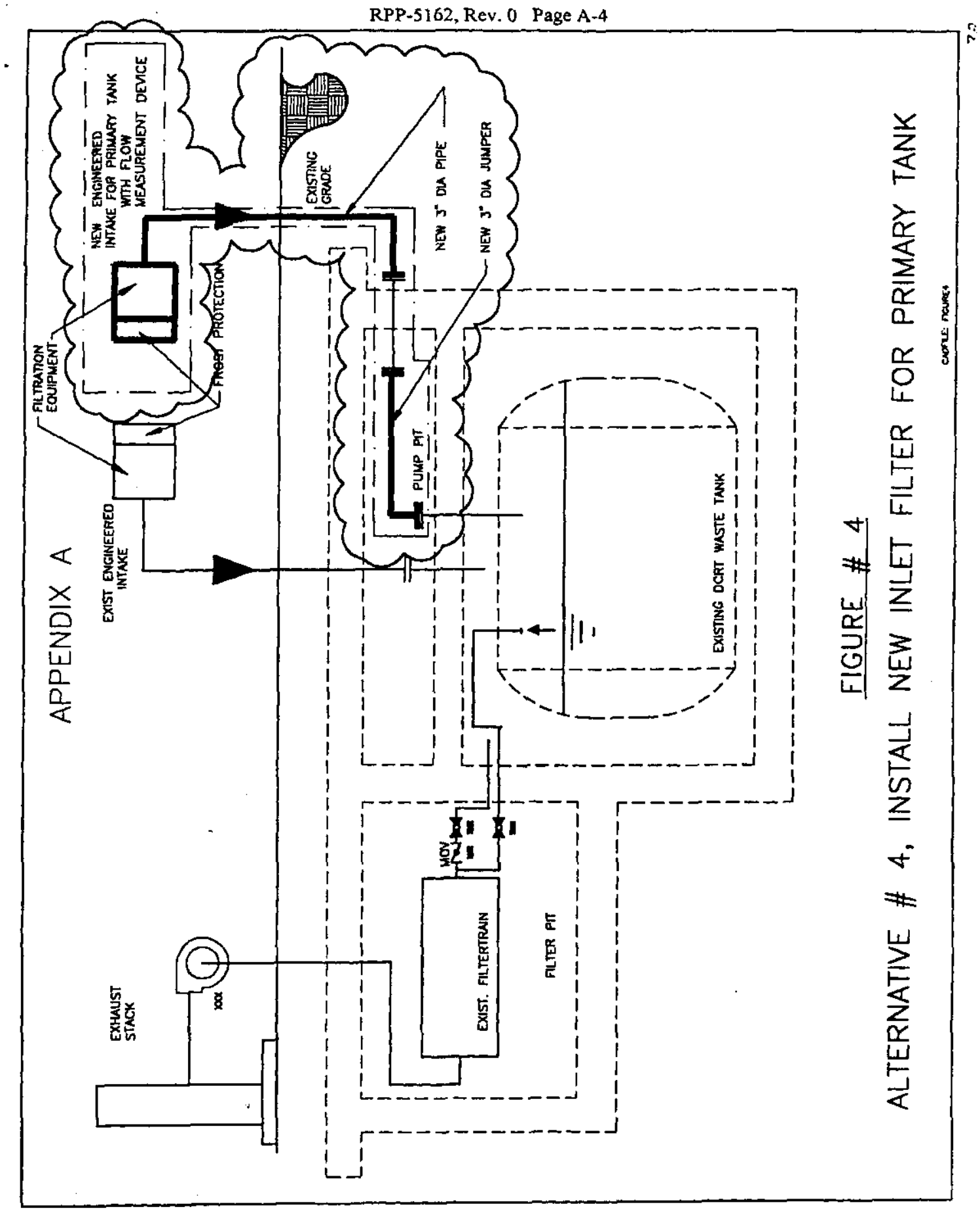




\section{RPP-5554 REV 0}

RPP-5162, Rev. 0 Page A-5

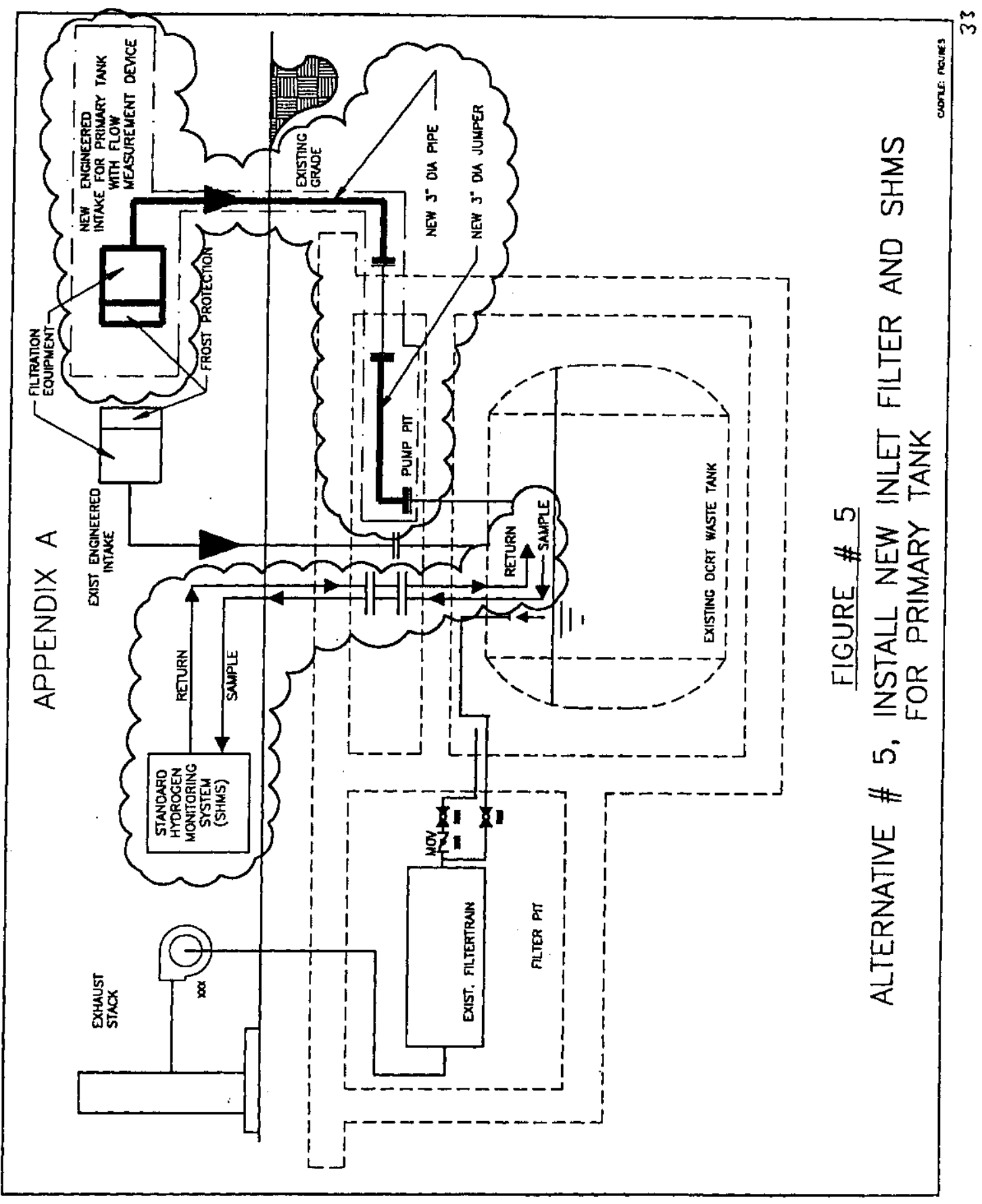


RPP-5554 REV 0

RPP-5162, Rev. 0 Page A-6

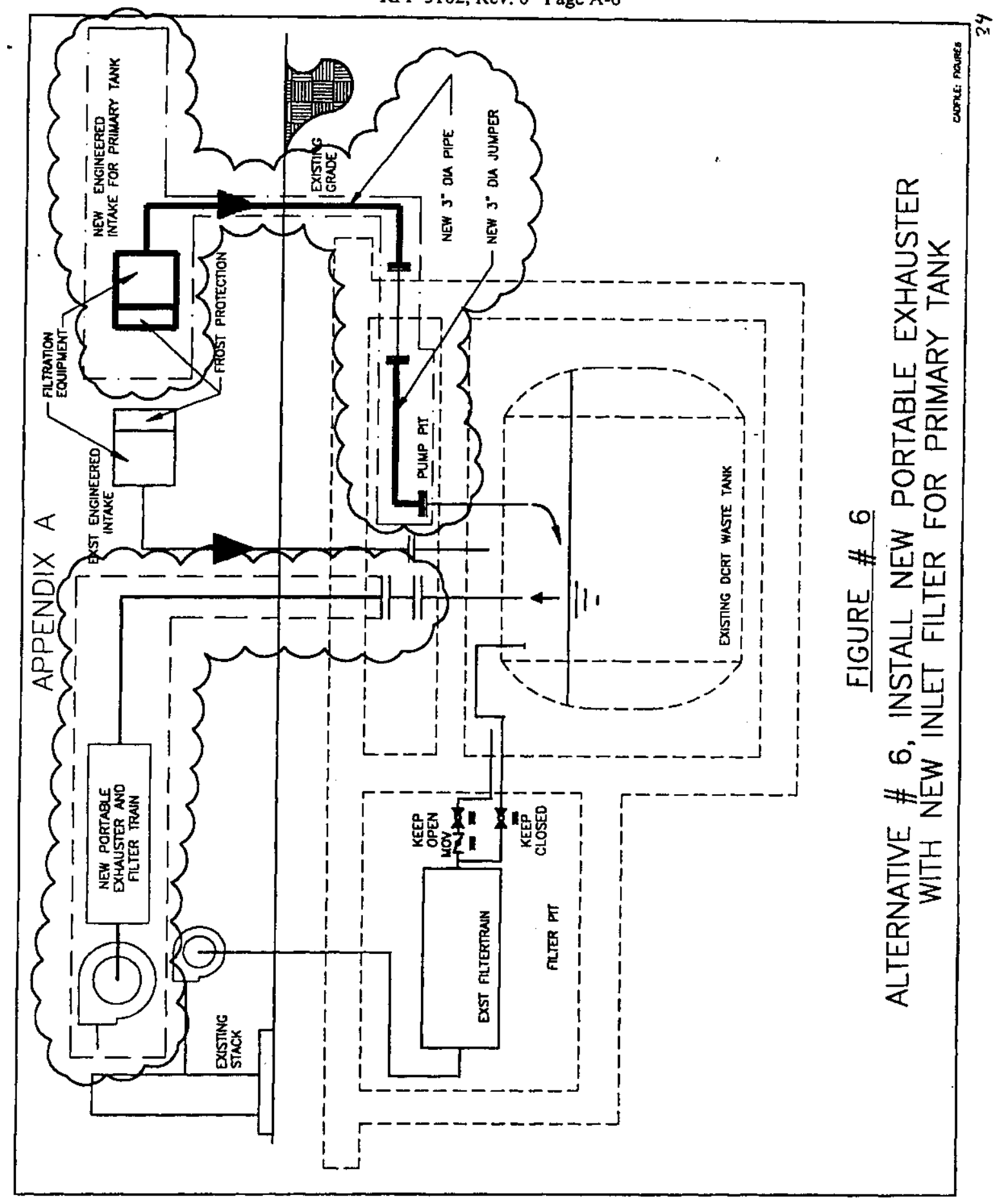


RPP-5554 REV 0

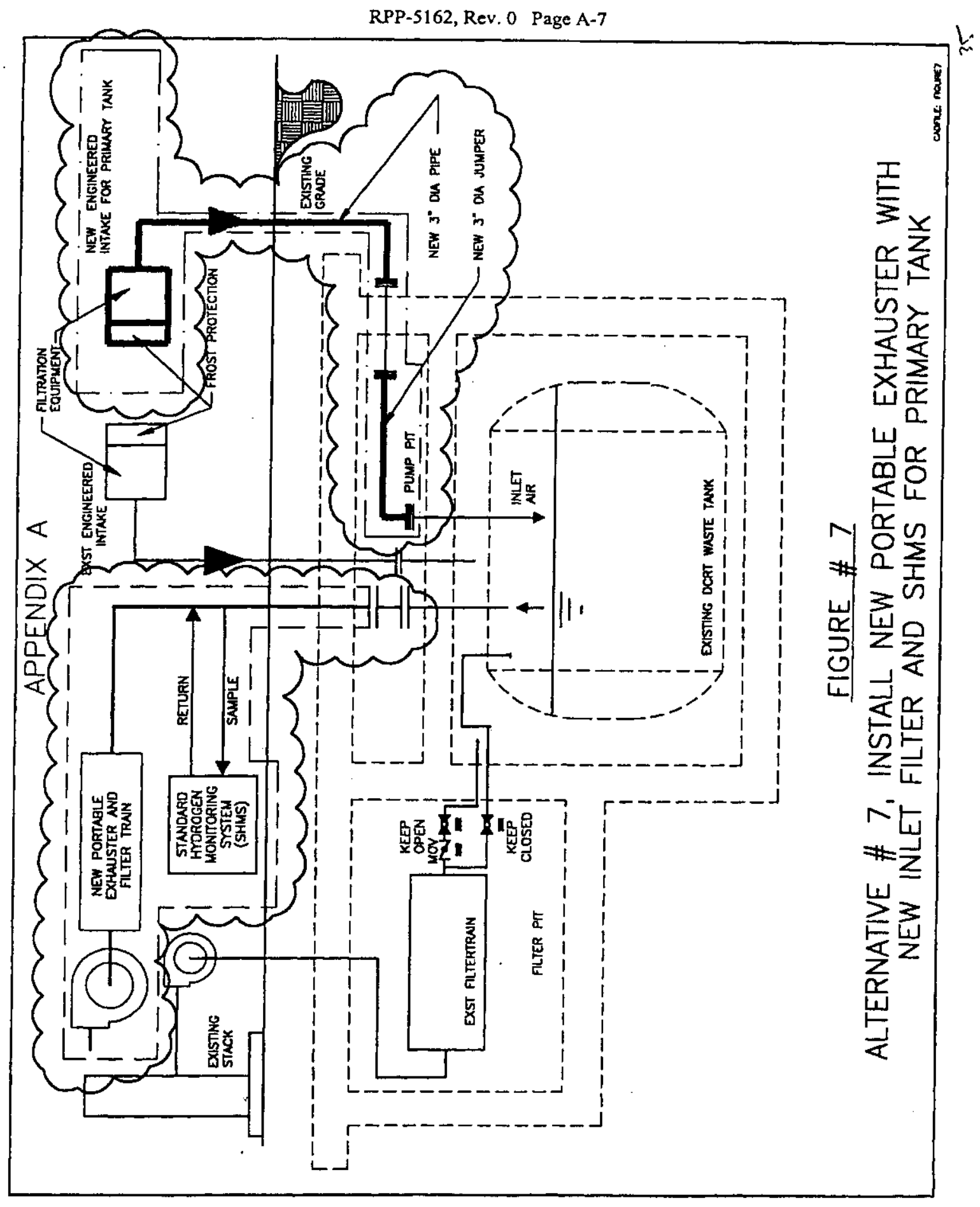




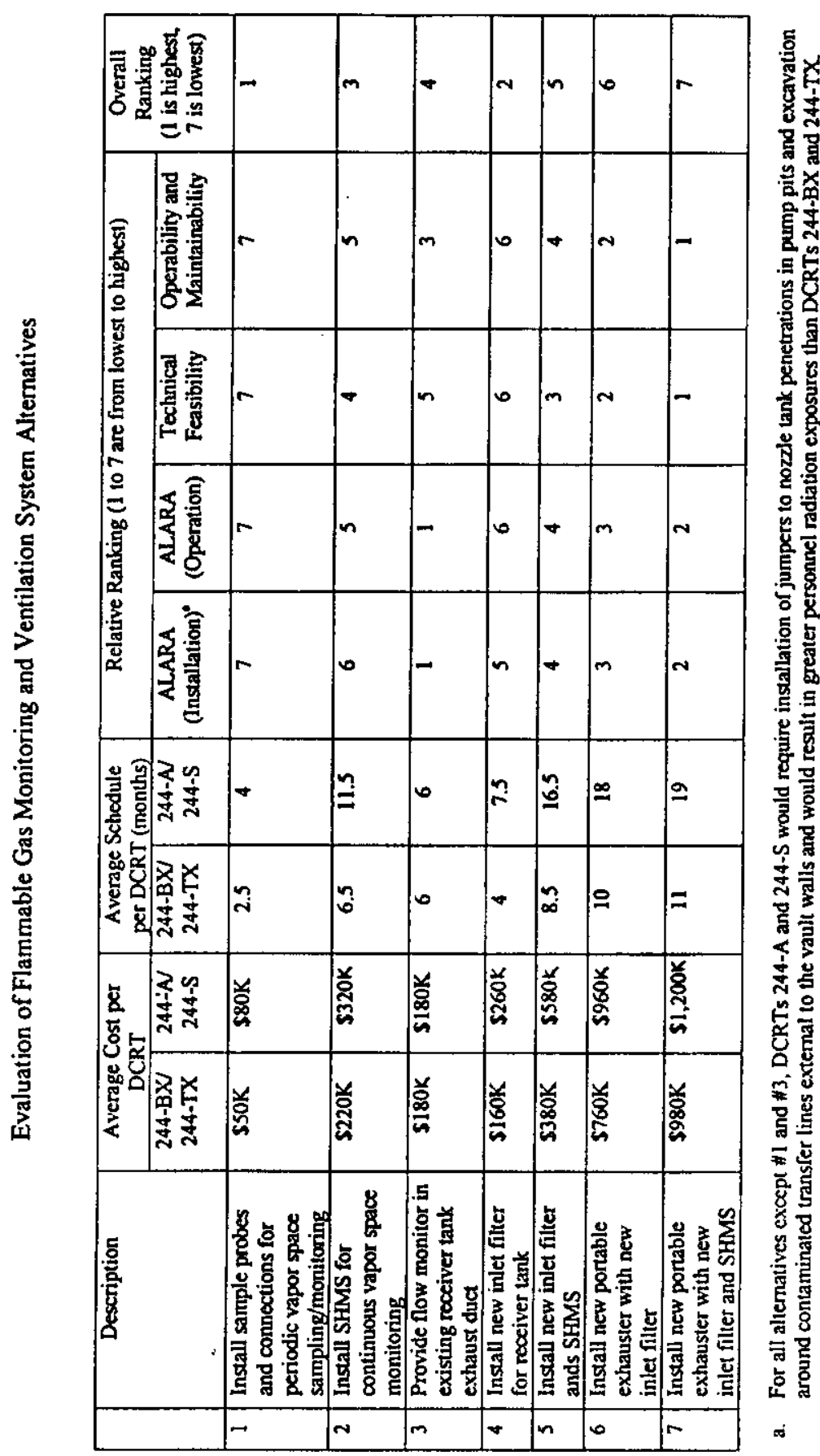

i 
RPP-5554 REV 0

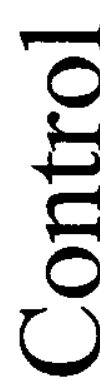

m

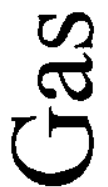

$\frac{1}{0} \cdot \frac{1}{60}$

$\sum_{\infty}^{\infty} \frac{1}{\infty}$

I

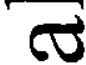

(1)

5

(1)

(1) 


\section{RPP-5554 REV 0}

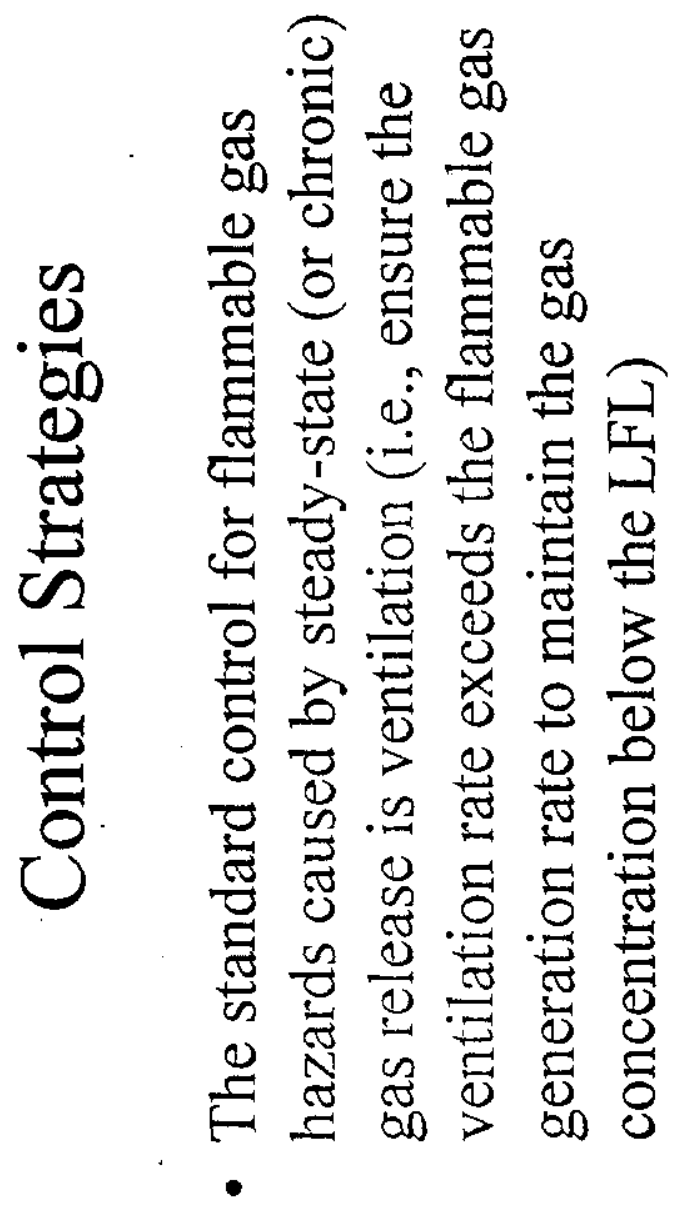

Att 4-38 


\section{RPP-5554 REV 0}

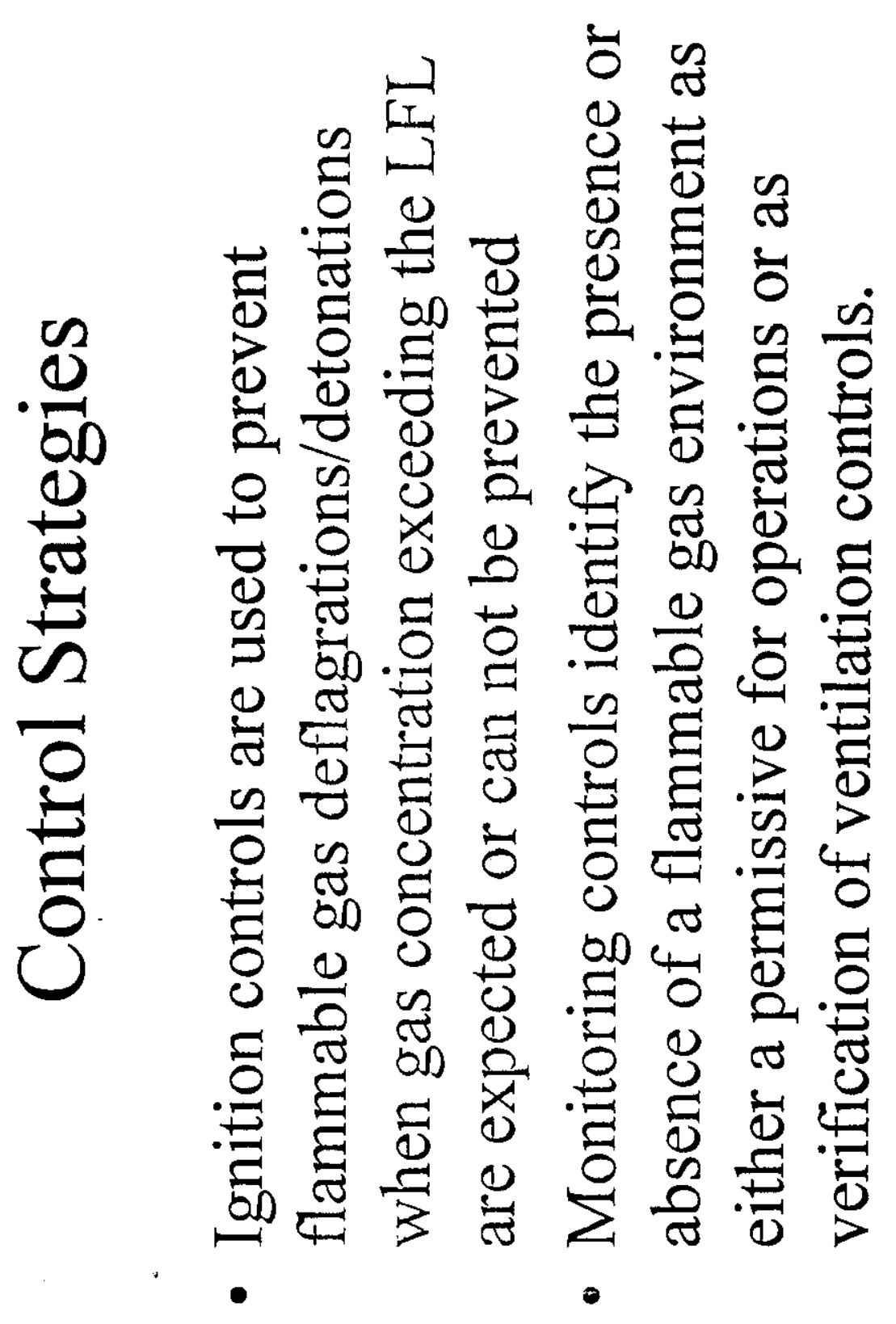


RPP-5554 REV 0

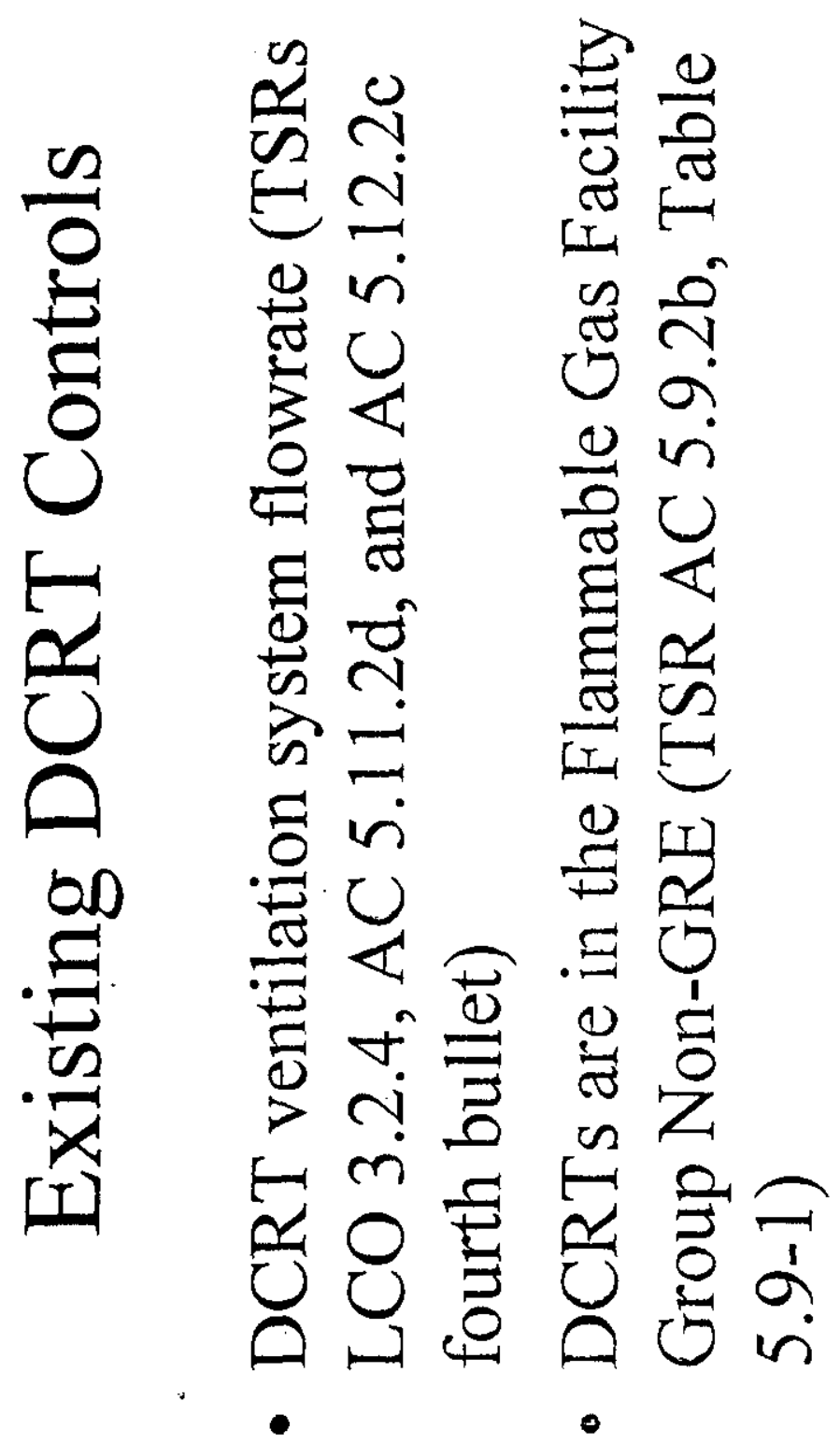


RPP-5554 REV 0

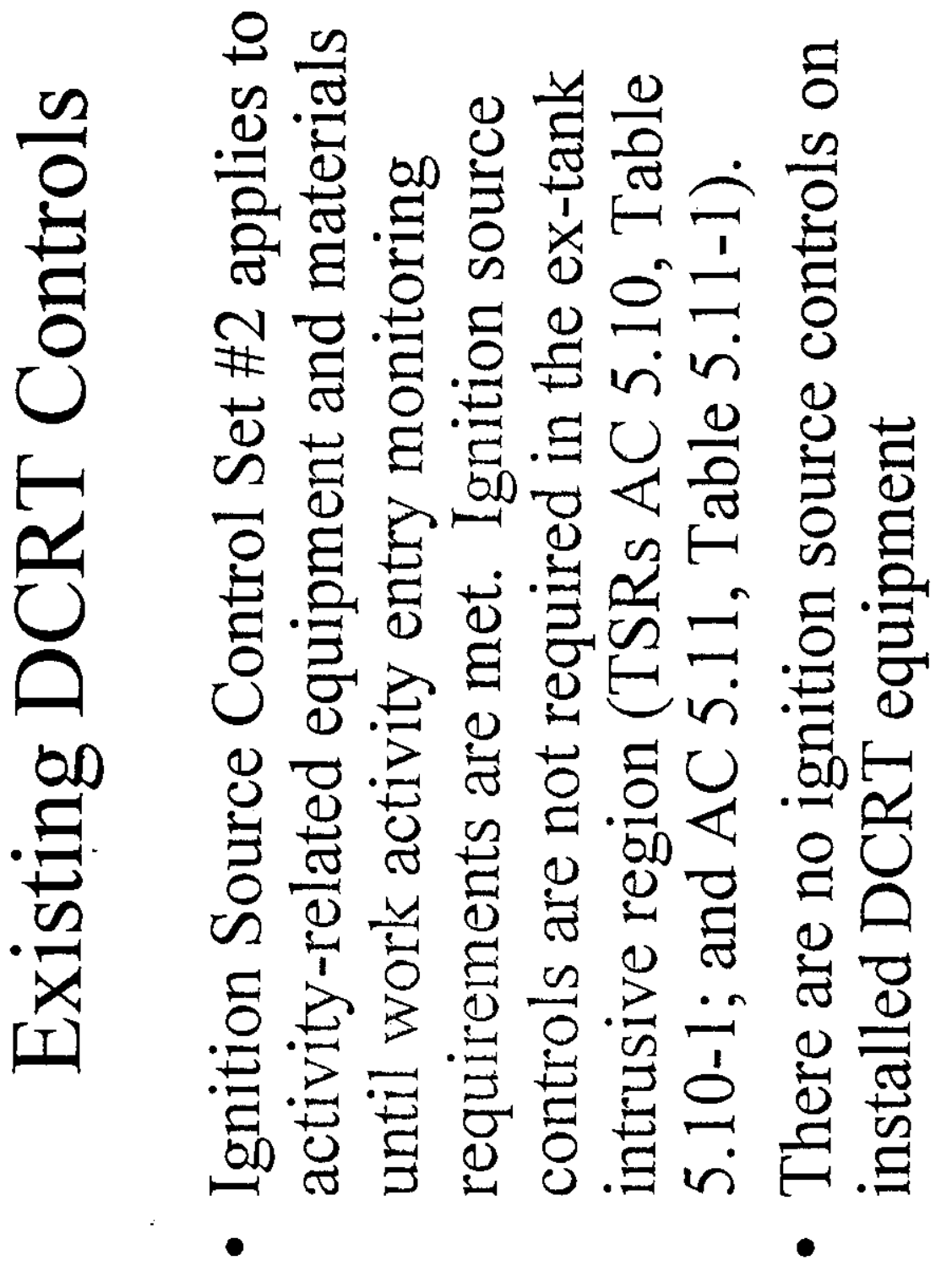




\section{RPP-5554 REV 0}

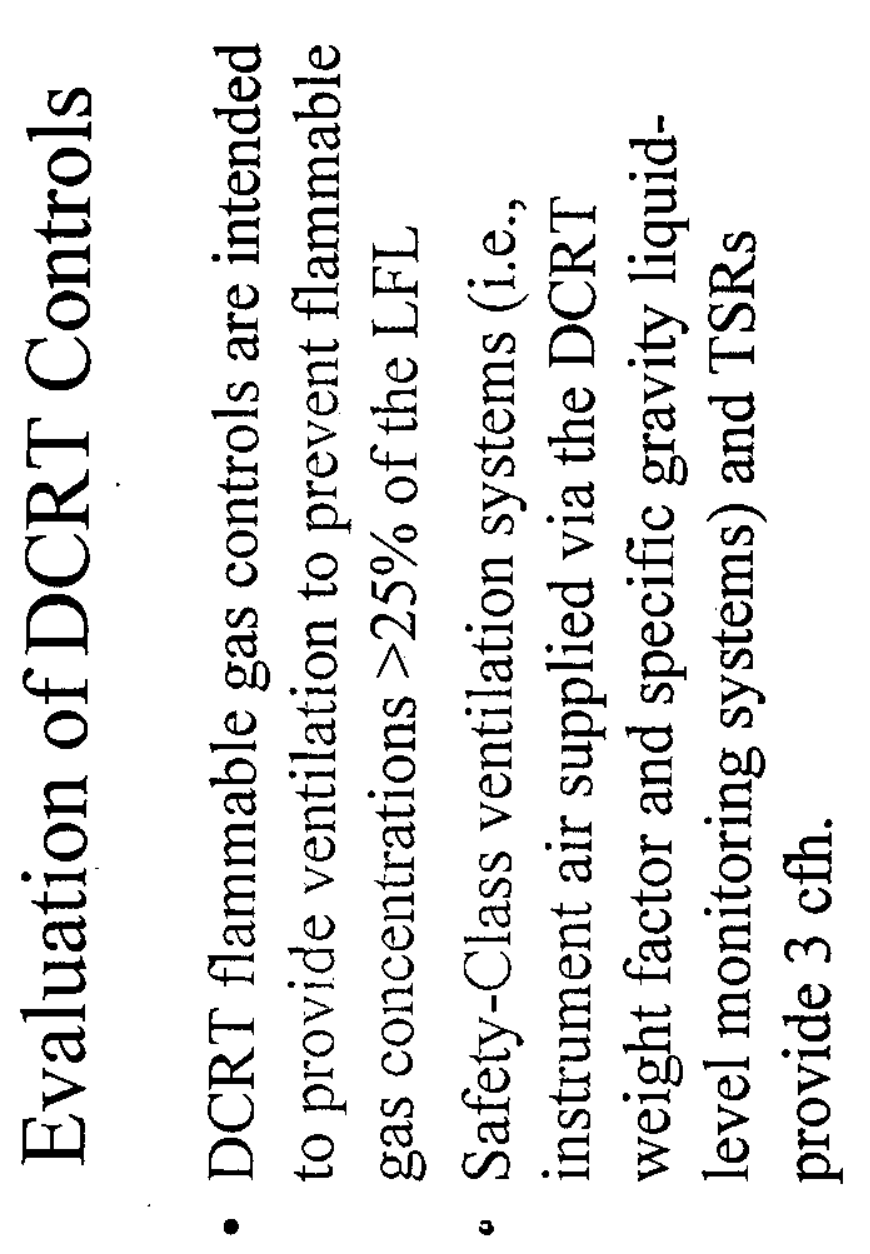


RPP-5554 REV 0

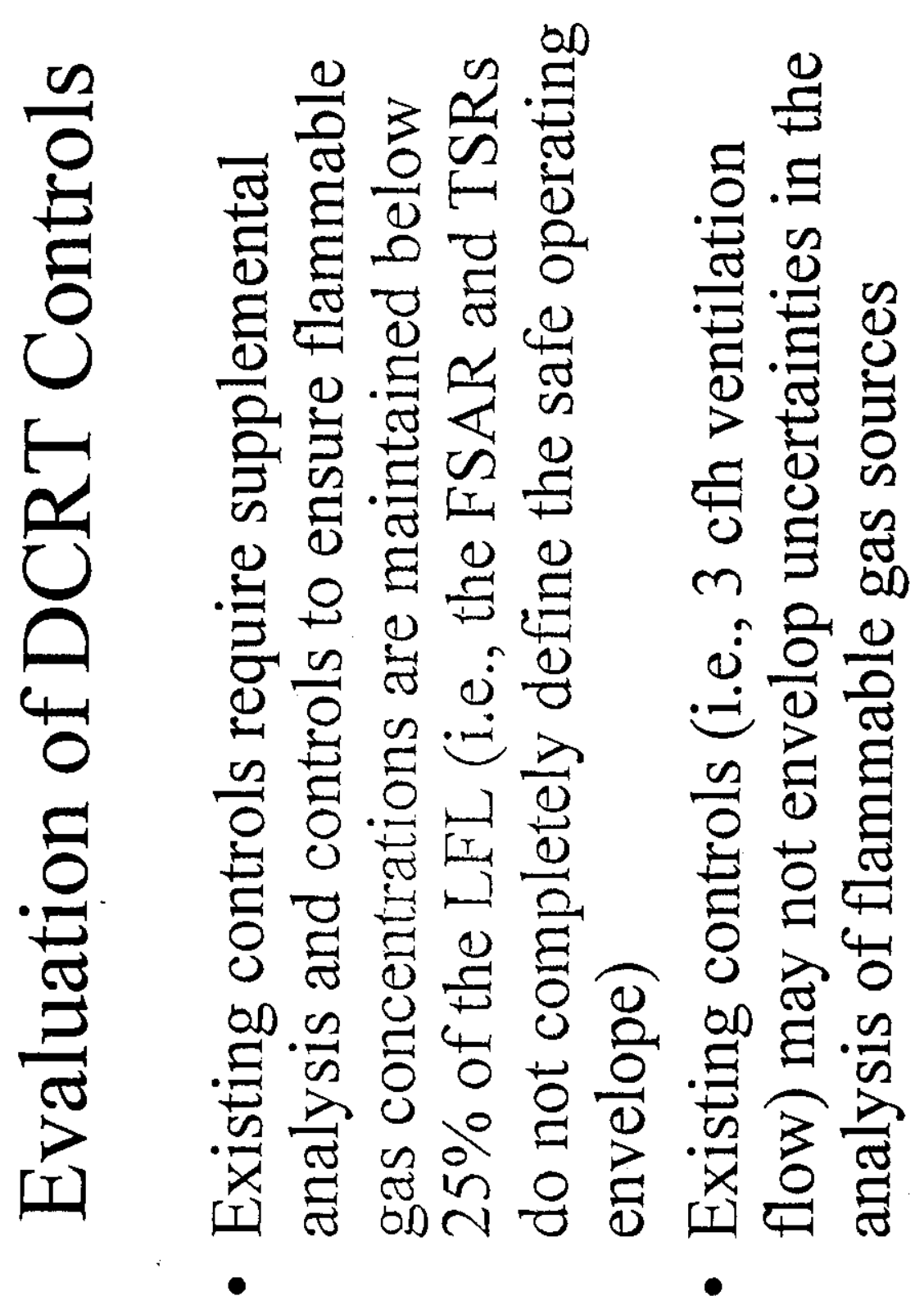


RPP-5554 REV 0

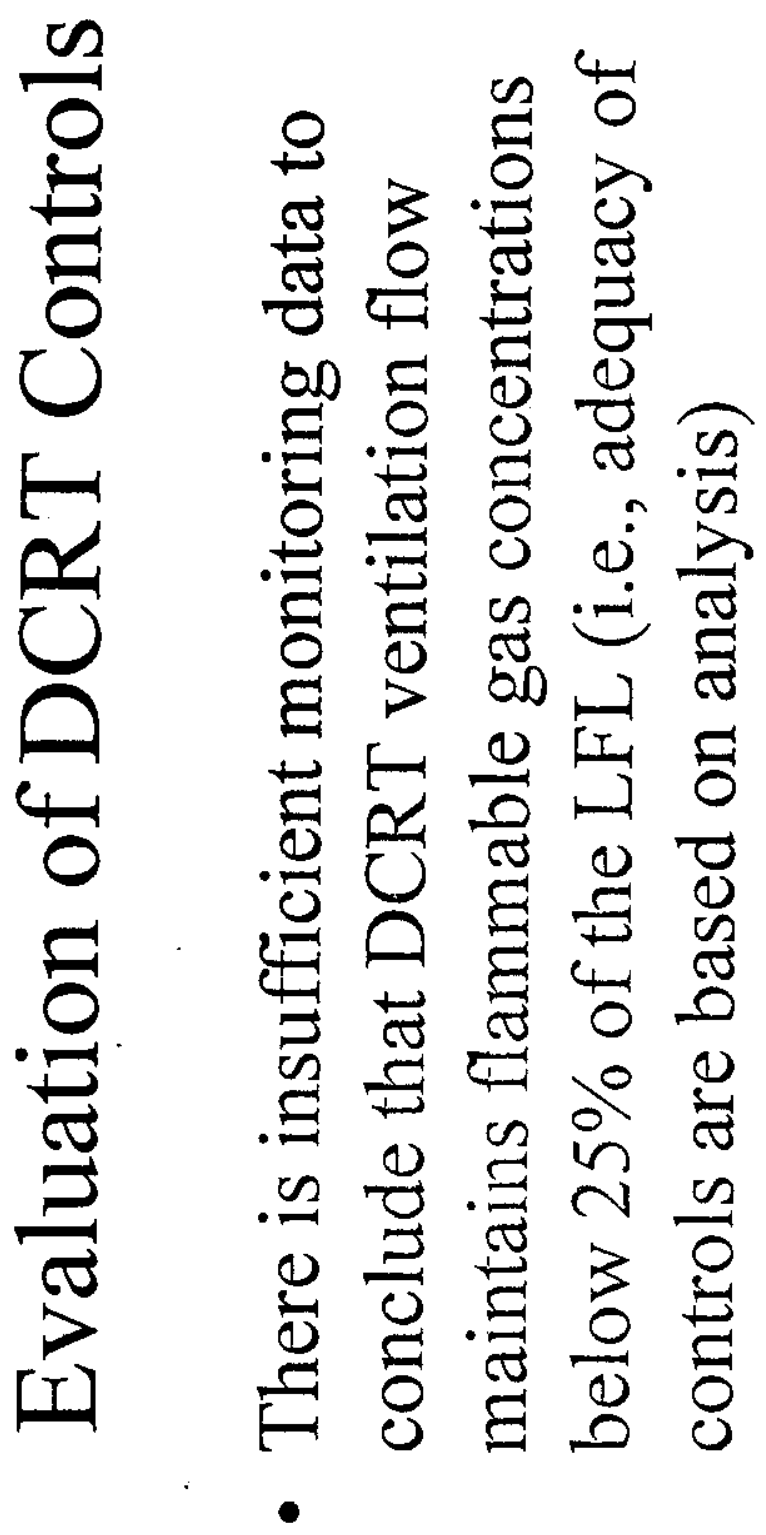


RPP-5554 REV 0

ATTACHMENT 5

CONTROL DECISION MEETING ON APRIL 19, 2000 TO ADDRESS FLAMMABLE GAS HAZARDS IN DCRTS AND WASTE TRANSFER SYSTEMS 
RPP-5554 REV 0

This page intentionally left blank.

Att 5-ii 
RPP-5554 REV 0

\section{ATTACHMENT 5 - PART 1}

AGENDA FOR CONTROL DECISION MEETING ON APRIL 19, 2000 TO ADDRESS FLAMMABLE GAS HAZARDS IN DCRTS AND WASTE TRANSFER SYSTEMS

Att 5-1 


\section{Agenda for Control Decision Meeting on April 19, 2000 To Address Flammable Gas Hazards in DCRTs and Waste Transfer Systems}

\section{April 19, 2000 (Wednesday)}

Note: All times are estimates and may vary.

\section{1:00- 1:15 Introduction}
A. Purpose
B. Scope
C. Process

1:15-1:45 New and Revised Accident Analyses

A. Revised frequencies and consequences of flammable gas deflagrations and detonations in DCRTs and the effect on the classification of safety SSCs (i.e., DCRT ventilation systems)

B. Estimated consequences of flammable gas deflagrations in RCSTS diversion box 6241-A and vent station $6241-\mathrm{V}$ and the effect on the classification of safety SSCs (e.g., leak detection systems)

1:45-2:15 New and Revised Predictions of Flammable Gas Concentrations
A. Revised predictions for DCRTs 244-A, 244-BX, 244-S, 244-TX and 244-U
B. New predictions for 244-CR Vault Tank 003 to support interim stabilization of the vault and the need for controls
C. New predictions for waste leaks into the DCRT vaults and the need for controls

\section{2:15-2:30 Break}

2:30-3:00 Draft LCO 3.2.4, DCRT Ventilation Systems (i.e., air supply flow rate, required actions and completion times, surveillance frequencies)

3:00-3:15 Draft AC 5.9
A. Waste transfer-associated structure ventilation control
B. Waste transfer prohibitions

\section{3:15-4:00 Draft AC 5.11.2d, DCRT (Flammable Gas Monitoring) Controls}
A. Continuous monitoring during salt well pumping
B. Periodic monitoring

\section{4:00-4:30 Summary}


RPP-5554 REV 0

ATTACHMENT 5 - PART 2

ATTENDANCE RECORD OF CONTROL DECISION MEETING

FOR FLAMMABLE GAS HAZARDS IN DCRTS AND

WASTE TRANSFER SYSTEMS ON APRIL 19, 2000

Att 5-3 
RPP-5554 REV 0

Attendance Record of Control Decision Meeting for Flammable Gas Hazards in CRTs and Waste Transfer Systems on April 19, 2000

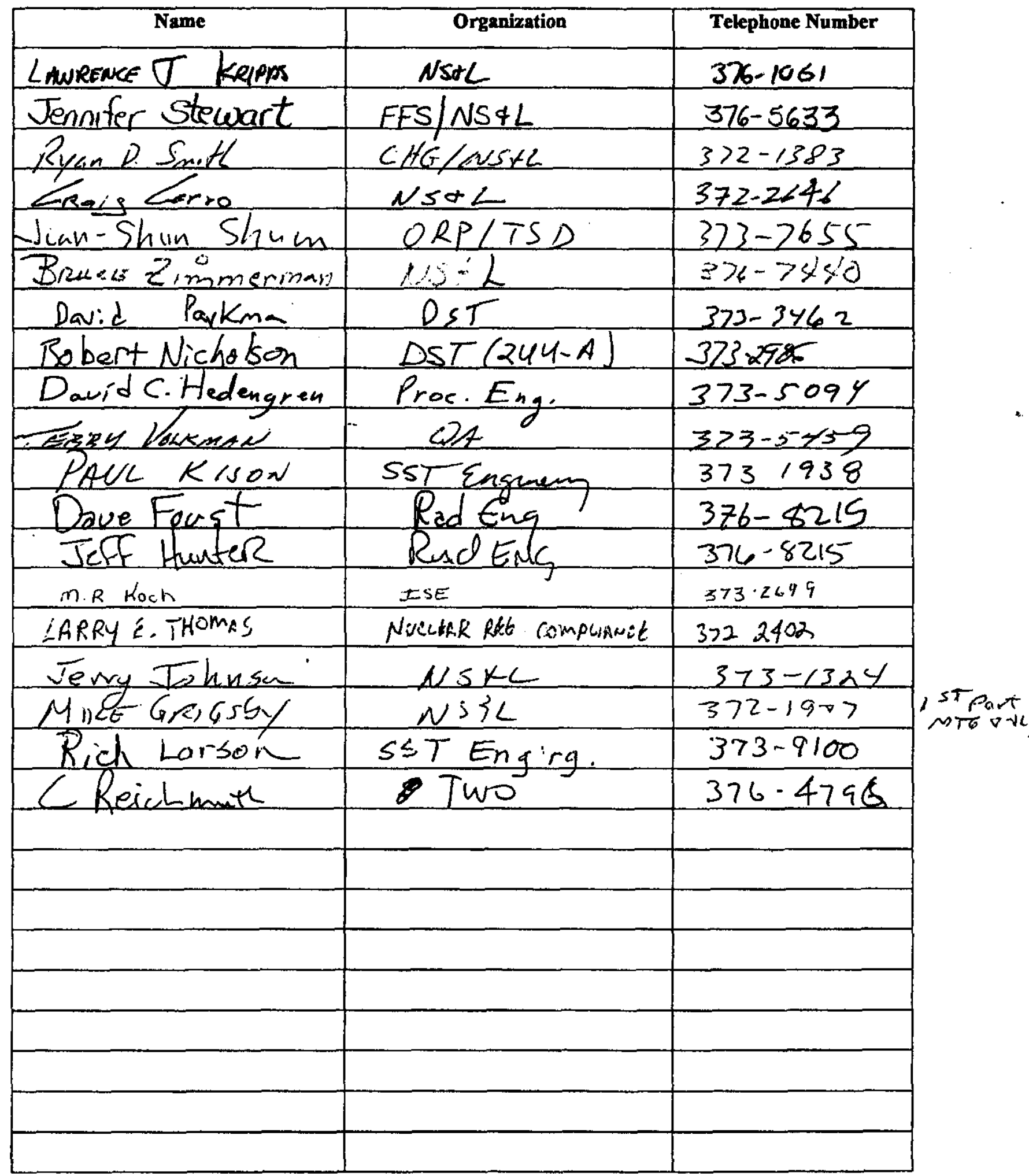

Att 5-4 
RPP-5554 REV 0

ATTACHMENT 5 - PART 3

PURPOSE, SCOPE, AND PROCESS FOR CONTROL DECISION MEETING TO ADDRESS DCRT AND WASTE TRANSFER SYSTEM

FLAMMABLE GAS HAZARDS

Att 5-5 


\section{CONTROL DECISION MEETING TO ADDRESS DCRT AND WASTE TRANSFER SYSTEM FLAMMABLE GAS HAZARDS}

Note: Controls include safety-class and safety-significant structures, systems, and components (SSCs); technical safety requirements (TSRs); and other controls that provided defense-in-depth or environmental protection.

\section{Purpose:}

The purpose of the control decision meeting is to review and revise previously selected controls for the prevention or mitigation of flammable gas hazards in double-contained receiver tanks (DCRTs) and waste transfer systems. The control decision meeting is needed to consider new and revised analyses since the November 16,17, and 18, 1999 control decision meetings for DCRTs and the November 30, 1999 control decision meeting for waste transfer systems. The control decisions and their basis support the closure of the Flammable Gas Unreviewed Safety Question (USQ) for DCRTs and waste transfer systems.

\section{Scope:}

The scope of the control decision meeting covers potential flammable gas hazards in DCRTs (i.e., 244-A, 244-BX, 244-S, 244-TX, 244-U, and 244-CR Vault Tank 003) and in waste transfer systems (i.e., waste transfer piping and waste transfer-associated structures).

\section{Process:}

The control decision process and the criteria for control decisions are described in the FSAR (HNF-SD-WM-SAR-067) along with the methodology for the hazard and accident analyses whose results are used to identify controls. Control decision criteria are summarized in Attachment I.

Control decisions will be based on the best available information from the hazard and accident analyses and on the technical expertise and experience of the meeting participants. Decisions will be made by consensus.

Required participants in the DCRT and waste transfer system flammable gas hazard control decision meeting are representatives from operations, engineering (including SST and DST Design Authority and cognizant engineers), interim stabilization, process engineering, and nuclear safety and licensing. Control decision meeting participants may also include representatives from waste retrieval, nuclear regulatory compliance support, radiological control, safety and emergency preparedness, environmental, and quality assurance. Personnel responsible for developing the information or performing the analysis supporting control decisions will be present at the control decision meeting. U.S. Department of Energy (DOE) Office of River Protection (ORP) staff have been invited to observe the control decision meeting.

The control decision meeting discussions will be documented, including the control decisions (see Attachment II). This documentation will be included or referenced in an amendment to the Authorization Basis (i.e., FSAR and TSRs) containing the proposed basis and control revisions to close the Flammable Gas USQ for DCRTs and waste transfer systems. DOE review and approval of the Authorization Basis amendment will be required. 


\section{SUMMARY OF CONTROL DECISION CRITERIA}

Note: FSAR Section 3.3.1.5, "Controls Identification," contains a complete discussion of control decision criteria.

\section{Control decision criteria are based on the following documents}

DOE 5480.23, Nuclear Safety Analysis

DOE 5480.22, Technical Safety Requirements

DOE-STD-3009-94, Preparation Guide for U.S. Department of Energy Nonreactor Nuclear Facility Safety Analysis Reports

WHC-CM-46, Nonreactor Facility Safety Analysis Manual, Section 6, "Technical Safety Requirements," Rev. 1, and Section 9, "Safety Classification of Structures, Systems, and Components, Rev. 2.

Risk Evaluation Guidelines:

$\underline{\text { Radiological Risk Guidelines }}$

\begin{tabular}{|l|c|c|c|}
\hline Frequency category & Frequency range $(\mathrm{yr}-1)$ & \multicolumn{2}{|c|}{ Effective dose equivalent (rem) } \\
\cline { 3 - 4 } & & Onsite & Offsite \\
\hline Anticipated & $>10^{-2}$ to $\leq 10^{0}$ & 0.5 & 0.1 \\
\hline Unlikely & $>10^{-4}$ to $\leq 10^{-2}$ & 5 & 0.5 \\
\hline Extremely unlikely & $>10^{-6}$ to $\leq 10^{-4}$ & 10 & 4 \\
\hline
\end{tabular}

Toxicological Risk Guidelines

\begin{tabular}{|l|c|c|c|}
\hline \multicolumn{1}{|c|}{ Frequency category } & Frequency range $(\mathrm{yr}-\mathrm{I})$ & \multicolumn{2}{c|}{ Primary concentration guidelines } \\
\cline { 3 - 4 } & & Onsite & Offsite \\
\hline Anticipated & $>10^{-2}$ to $\leq 10^{0}$ & $\leq$ ERPG-1 & $\leq$ PEL-TWA \\
\hline Unlikely & $>10^{-4}$ to $\leq 10^{-2}$ & $\leq$ ERPG-2 & $\leq$ ERPG-1 \\
\hline Extremely unlikely & $>10^{-6}$ to $\leq 10^{-4}$ & $\leq$ ERPG-3 & $\leq$ ERPG-2 \\
\hline
\end{tabular}

ERPG $=$ Emergency Response Planning Guideline

PEL-TWA = permissible exposure limit - time-weighted average 


\section{Additional criteria to guide control decisions are the following}

- Control preferences are as follows:

1. Controls that prevent the accident versus those that mitigate its consequences

2. Passive engineered versus active engineered controls

3. Engineered controls versus administrative controls

- Controls providing significant defense-in-depth are classified as safety SSCs or are elevated to a TSR control

- TSR controls are not developed for postulated accidents resulting in only environmental consequences

- SSCs are not classified safety-class or safety-significant solely for preventing or mitigating postulated accidents resulting in environmental consequences

Other criteria that are important considerations in control decisions are listed below

- Control reliability, availability, and maintainability

- Control effects on facility workers (i.e., increased radiation doses or toxicological exposures - ALARA issues)

- Control optimization and integration

- Control cost/benefit

- Control human factors impacts

- Control impacts on TWRS mission 


\section{Attachment II}

\section{CONTROL DECISION RECORD}

\section{HAZARD/ACCIDENT TITLE:}

Structures, Systems, and Components (SSCs)

\begin{tabular}{|c|c|c|c|c|}
\hline \multirow{2}{*}{$\begin{array}{l}\text { Structures, Systems, } \\
\text { and Components }\end{array}$} & \multicolumn{2}{|c|}{ Classification } & \multirow{2}{*}{ Safety Function } & \multirow[t]{2}{*}{ Comments } \\
\hline & $S C^{*}$ & SS* & & \\
\hline & & & & \\
\hline & & & & \\
\hline & & & & \\
\hline
\end{tabular}

* $\quad$ SC is safety class

SS is safety significant

Technical Safety Requirements (TSRs)

\begin{tabular}{|c|c|c|}
\hline Control & Comments & Safety Function \\
\hline & & \\
\hline & & \\
\hline & & \\
\hline
\end{tabular}

Defense-in Depth Controls

\begin{tabular}{|l|l|l|}
\hline Control & Comments & Safety Function \\
\hline & & \\
\hline & & \\
\hline
\end{tabular}


RPP-5554 REV 0

ATTACHMENT 5 - PART 4

PRESENTATIONS AT THE CONTROL DECISION MEETING ON APRIL 19, 2000 TO ADDRESS FLAMMABLE

GAS HAZARDS IN DCRTS 
RPP-5554 REV 0

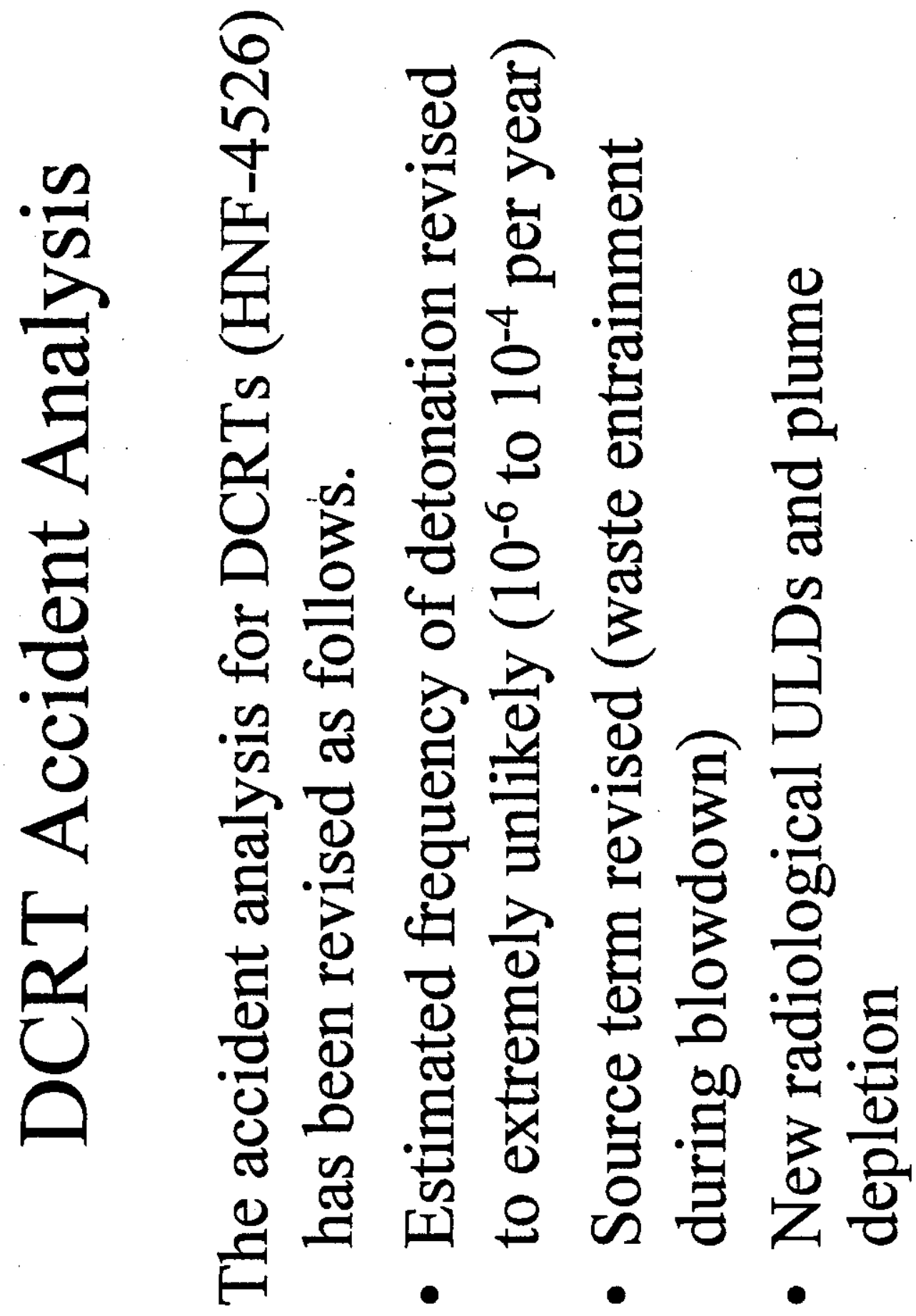

Att 5-11 
RPP-5554 REV 0

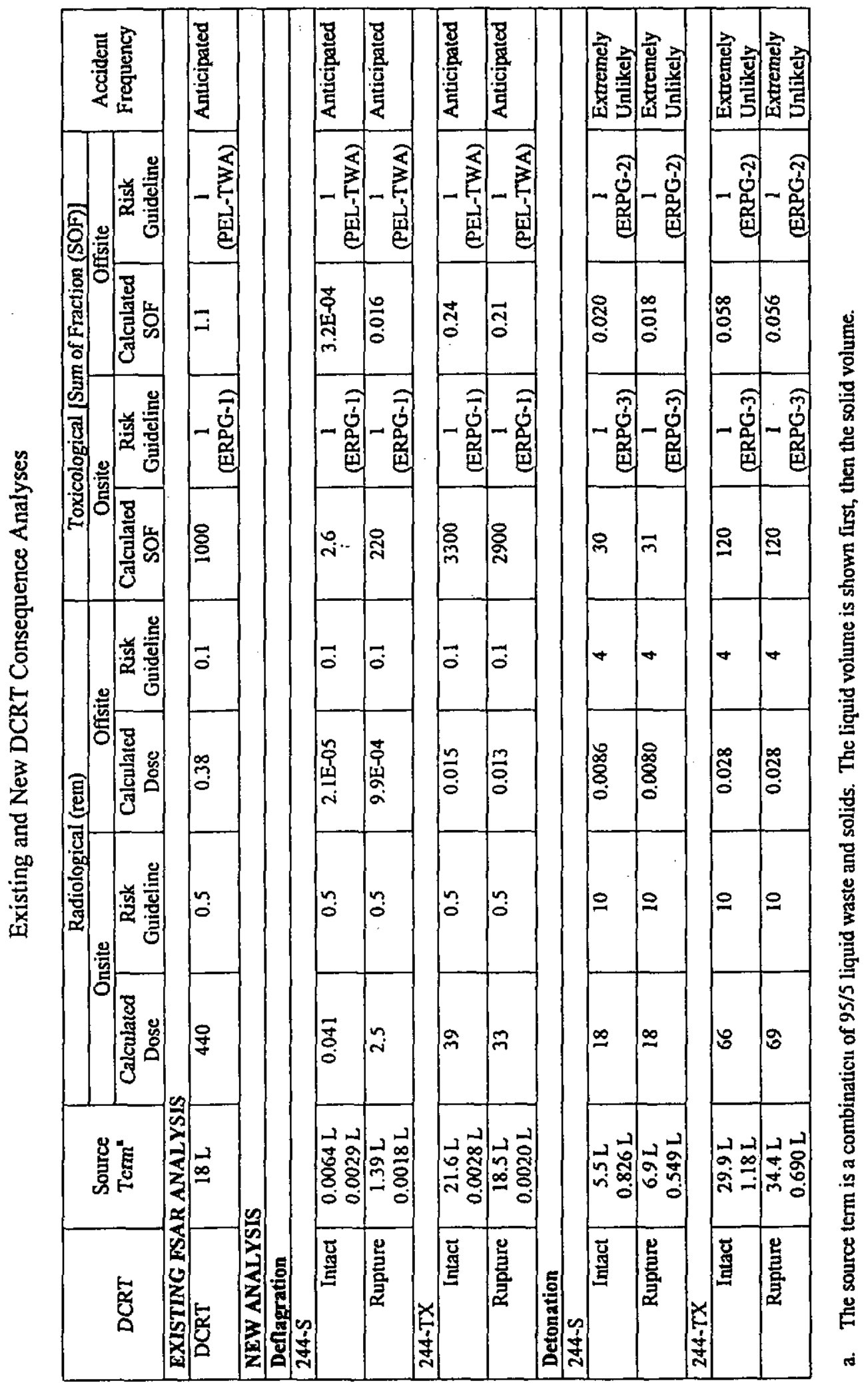


RPP-5554 REV 0
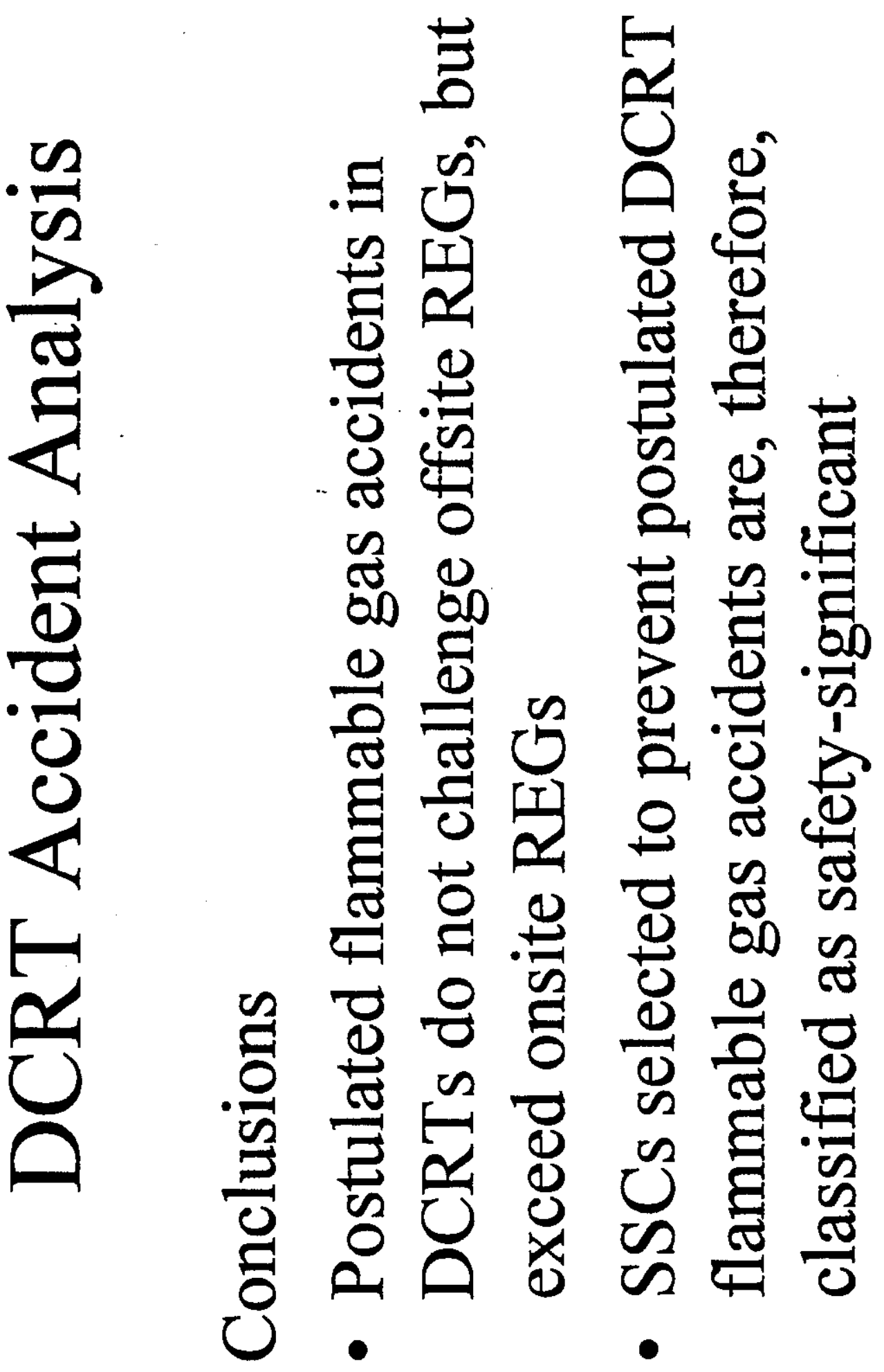
RPP-5554 REV 0

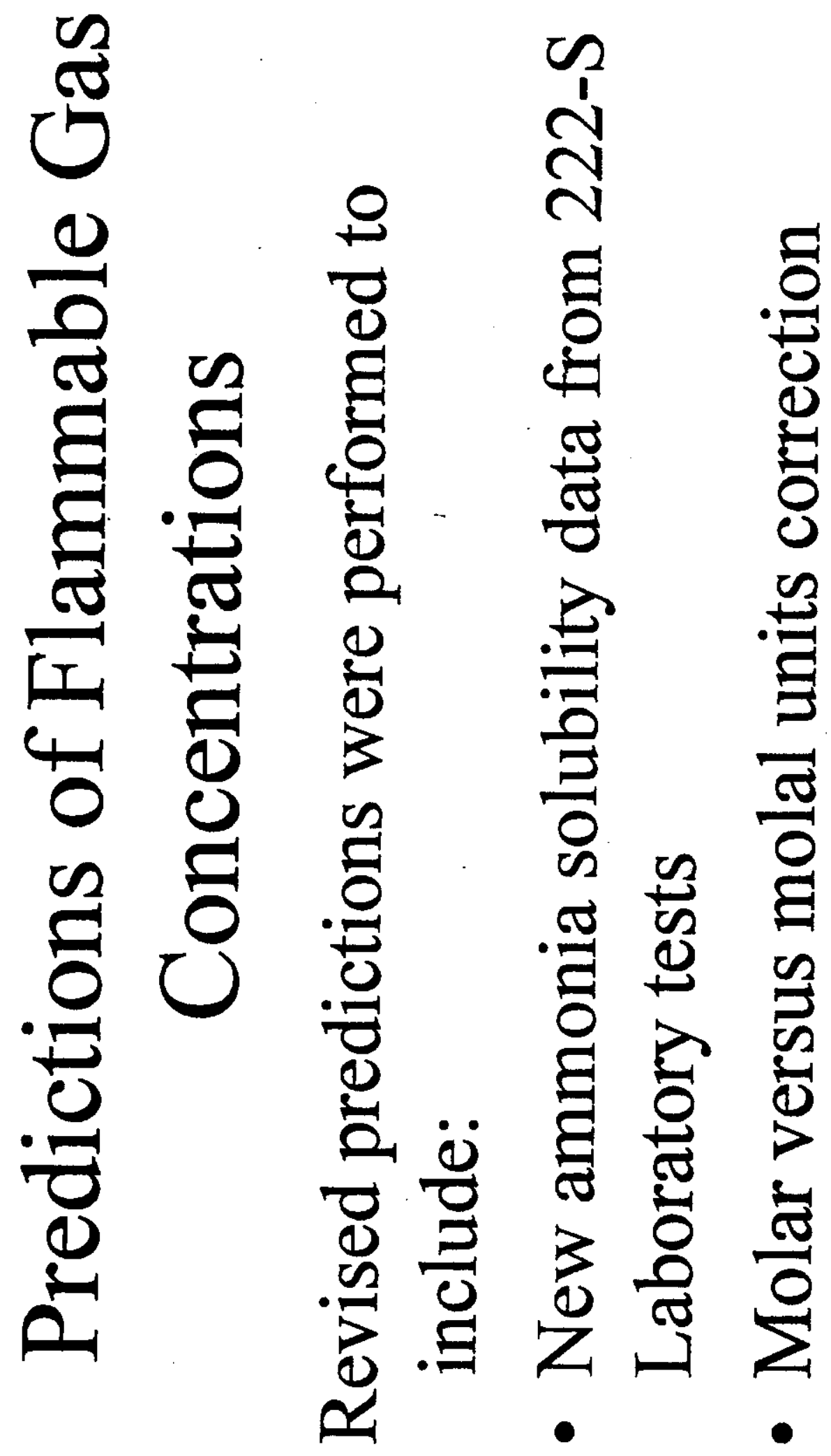


RPP-5554 REV 0

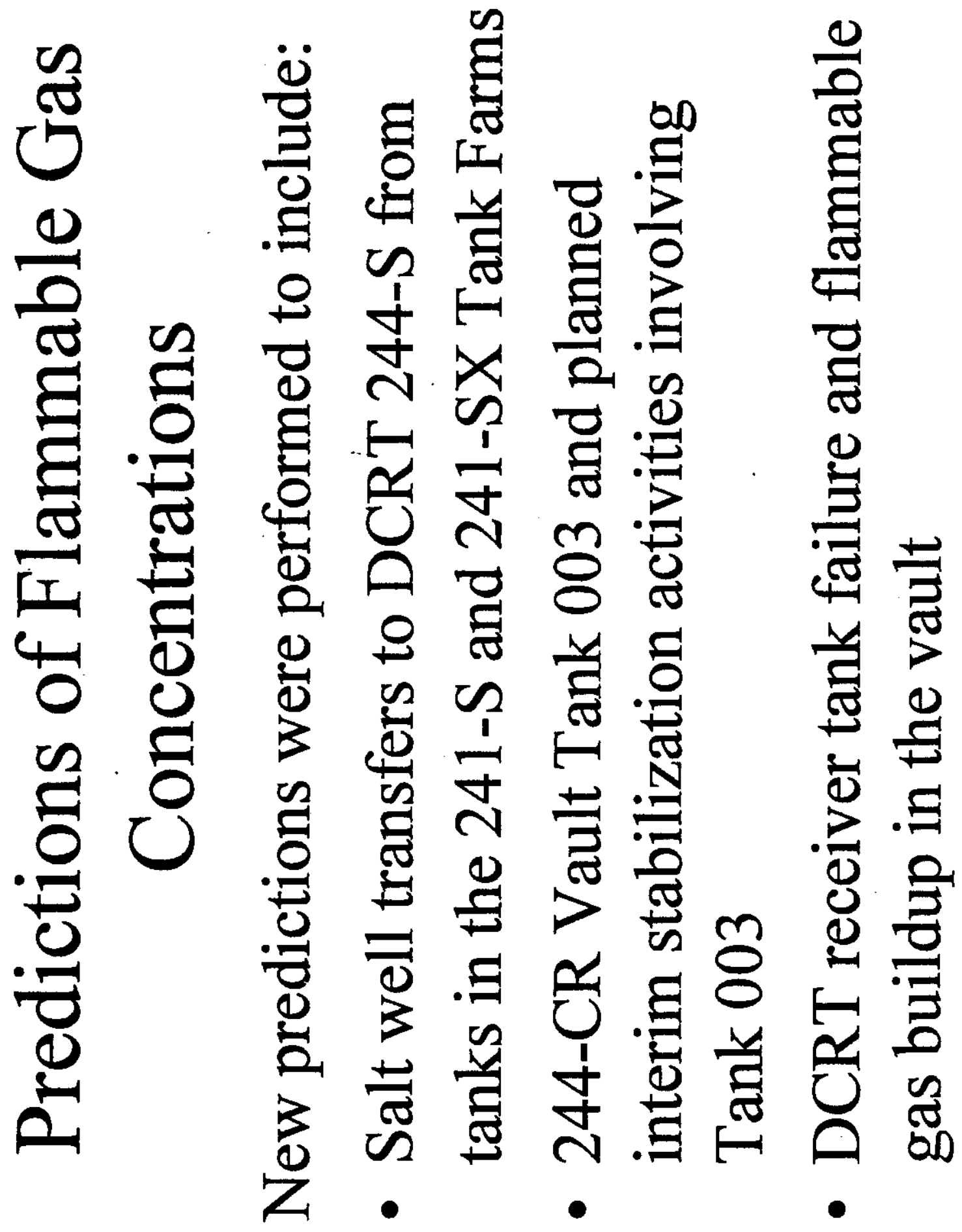




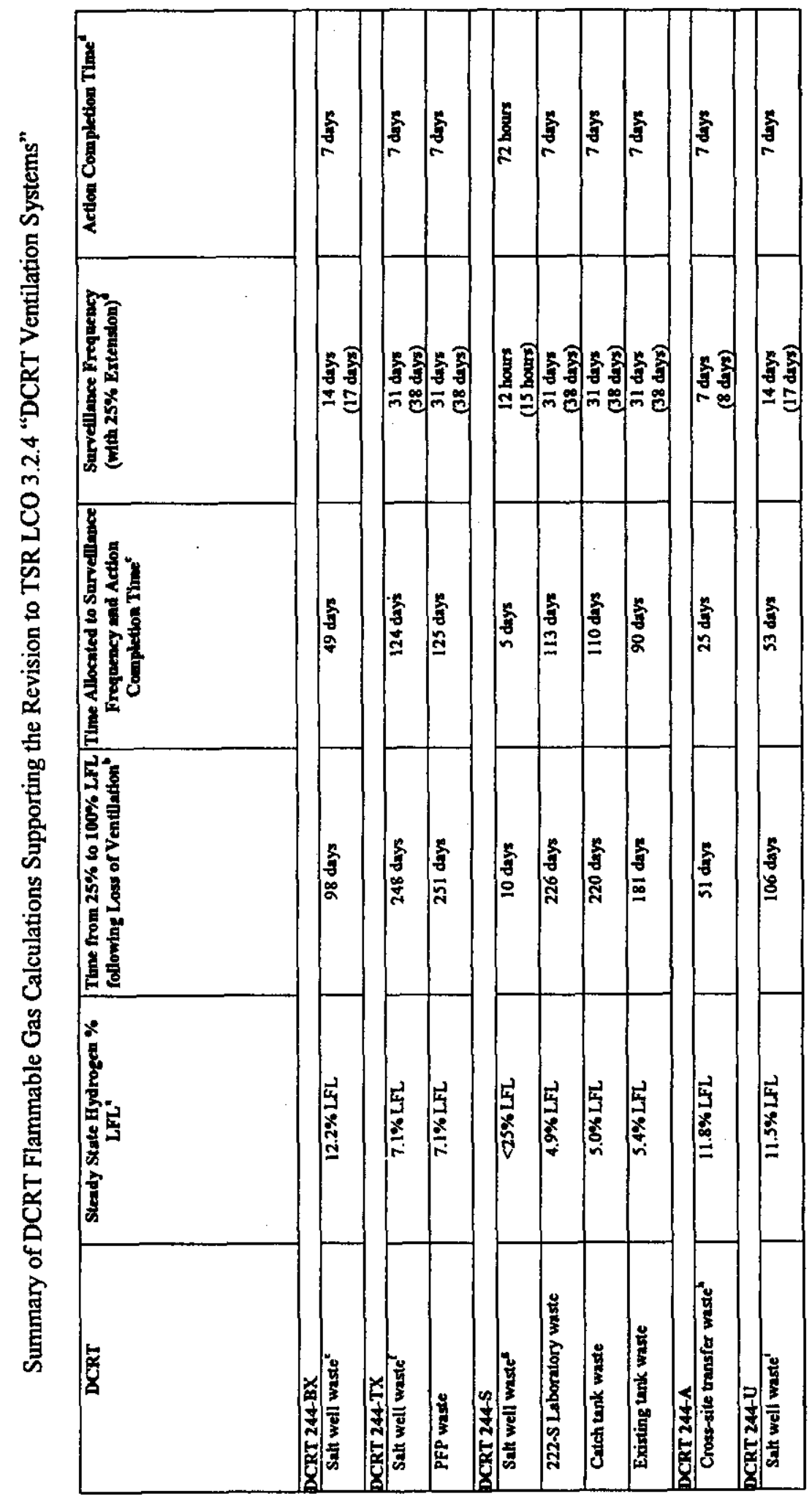




\section{RPP-5554 REV 0}

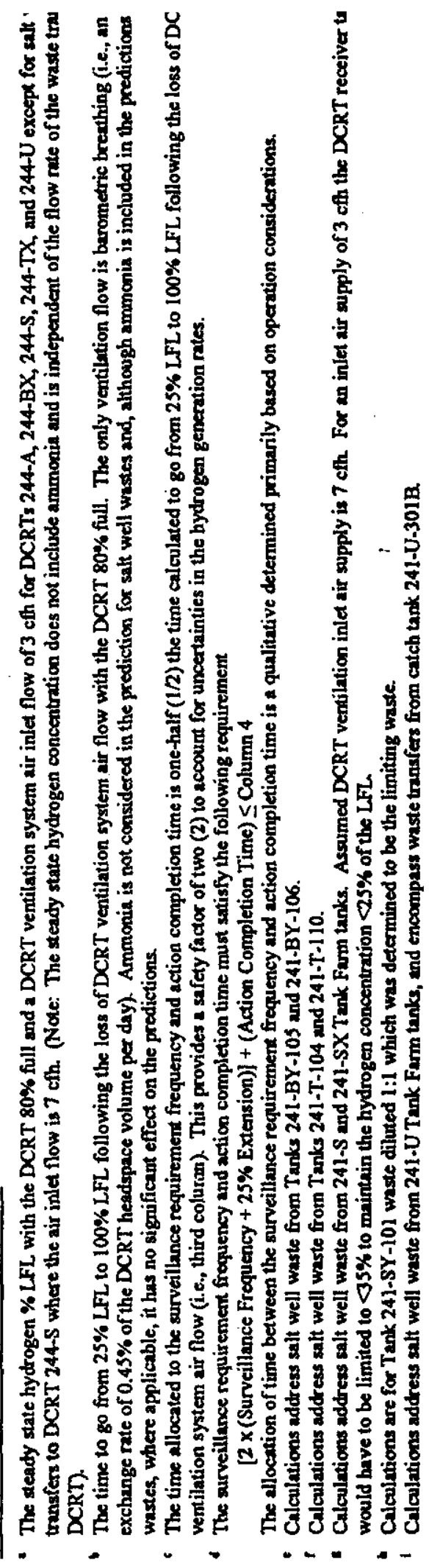

Att 5-17 
RPP-5554 REV 0

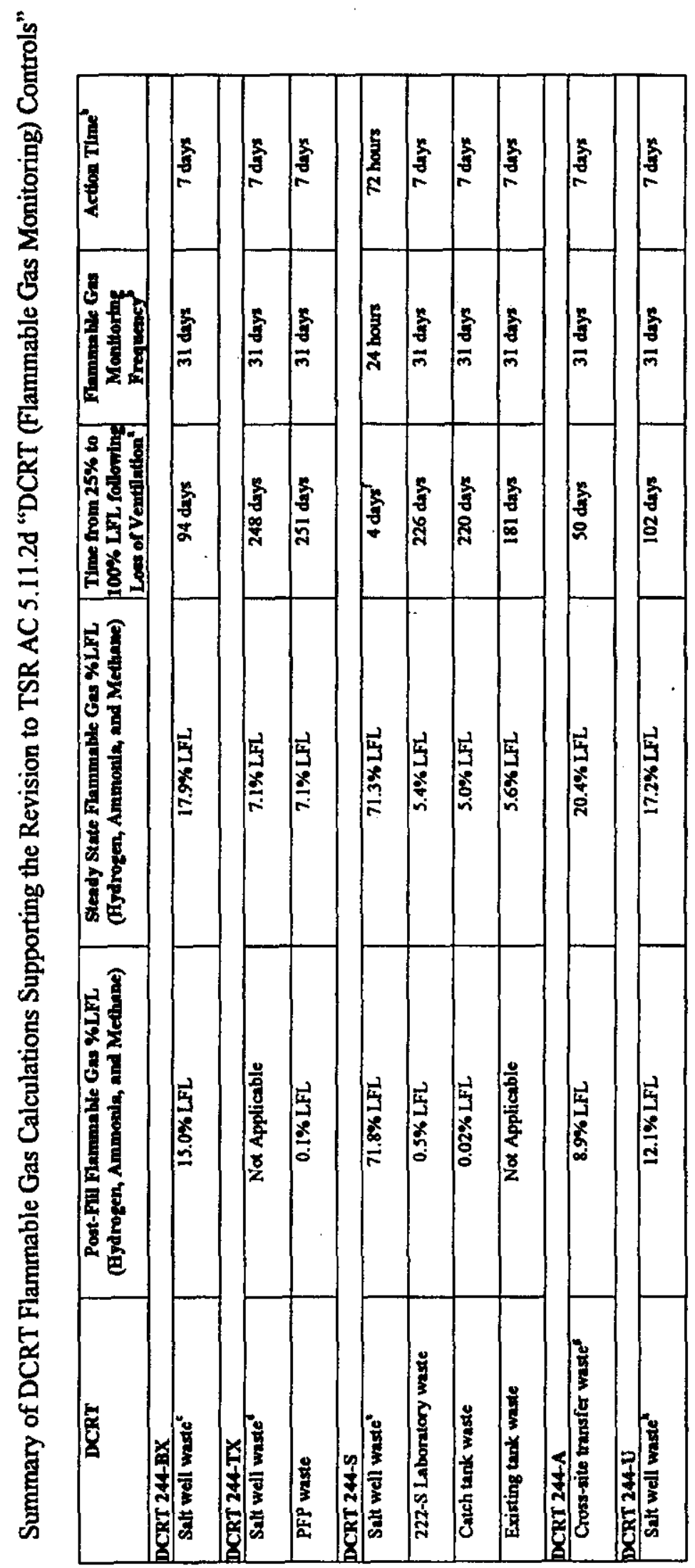

Att 5-18 
RPP-5554 REV 0

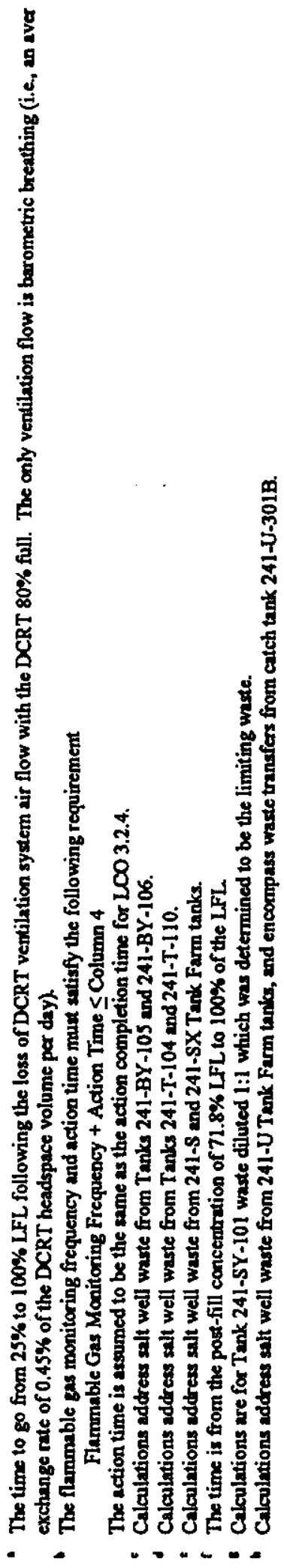


Summary of 244-CR Vault Tank 003 Flammable Gas Calculations Supporting TSR Control Revisions

\begin{tabular}{|c|c|c|c|c|}
\hline Scennito" & $\begin{array}{c}\text { Madmum Fammable } \\
\text { Gw \%LFL }\end{array}$ & The to $100 \%$ LXL & $\begin{array}{c}\text { Fammable Gma Monitorins } \\
\text { Prequency }\end{array}$ & Action Time \\
\hline Existing tank waste & $43 \%$ LFL & - & - & - \\
\hline $\begin{array}{l}\text { Waste transfers from } \\
\text { other } 244-C R \text { Vault tanks } \\
\text { and sumps for interim } \\
\text { tabilization of the vault } \\
\text { (i.e., tank } 80 \% \text { fill of } \\
\text { worst case composite } \\
\text { waste) }\end{array}$ & $\gg 100 \%$ LFL. & 143 hours & - & $\cdot$ \\
\hline $\begin{array}{l}\text { Final end state of Tank } \\
003 \text { (i.e., all pumpable } \\
\text { liquids removed following } \\
\text { interim stubilization of the } \\
\text { vault) }\end{array}$ & $\gg 100 \% \mathrm{LFL}$ & - & - & - \\
\hline
\end{tabular}

- The only ventilation flow assumed in all scensitios is barometric breathing (i.e., an average air exchange rate of $0.45 \%$ of the DCRT headspace volume per day).

- The flammable gas monitoring frequency and action time must satisfy the following requirement Flammable Gas Monitoring Frequency + Action Time $\leq 0.75 \bullet$ Column 3

The factor of 0.75 assumes a linear increase in the flammable gas concentration from $0 \%$ to $100 \%$ of the LFL and is included to estimate the time from $25 \%$ to $100 \%$ of the LFL. 
Summary of DCRT Vault Maximum Flammable Gas Concentrations

The table below summarizes the results of predictions of the maximum flammable gas concentration in a DCRT vault following the postulated failure of the DCRT receiver tank. The DCRT is assume to be $80 \%$ full of waste that will result in the highest flammable gas concentration. The only ventilation flow is barometric breathing (i.e., an average air exchange rate of $0.46 \%$ of the DCRT headspace volume per day).

\begin{tabular}{|l|c|}
\hline \multicolumn{1}{|c|}{ DCRT Vault } & $\begin{array}{c}\text { Marimum Flammable Gas } \\
\text { Concentration }\end{array}$ \\
\hline $244-\mathrm{A}$ & $57.5 \% \mathrm{LFL}$ \\
\hline $244-\mathrm{BX}$ & $27.7 \% \mathrm{LFL}$ \\
\hline $244-\mathrm{S}$ & \\
If no future salt well waste transfers & $43.9 \% \mathrm{LFL}$ \\
$\quad$ If future salt well waste transfers & $217.4 \% \mathrm{LFL}$ \\
\hline $244-\mathrm{TX}$ & $32.5 \% \mathrm{LFL}$ \\
\hline $244-\mathrm{U}$ & $26.2 \% \mathrm{LFL}$ \\
\hline 244-CR Vault & $>100 \% \mathrm{LFL}$ \\
\hline
\end{tabular}

i The predicted time to reach $100 \%$ of the LFL is 31 days. 
RPP-5554 REV 0

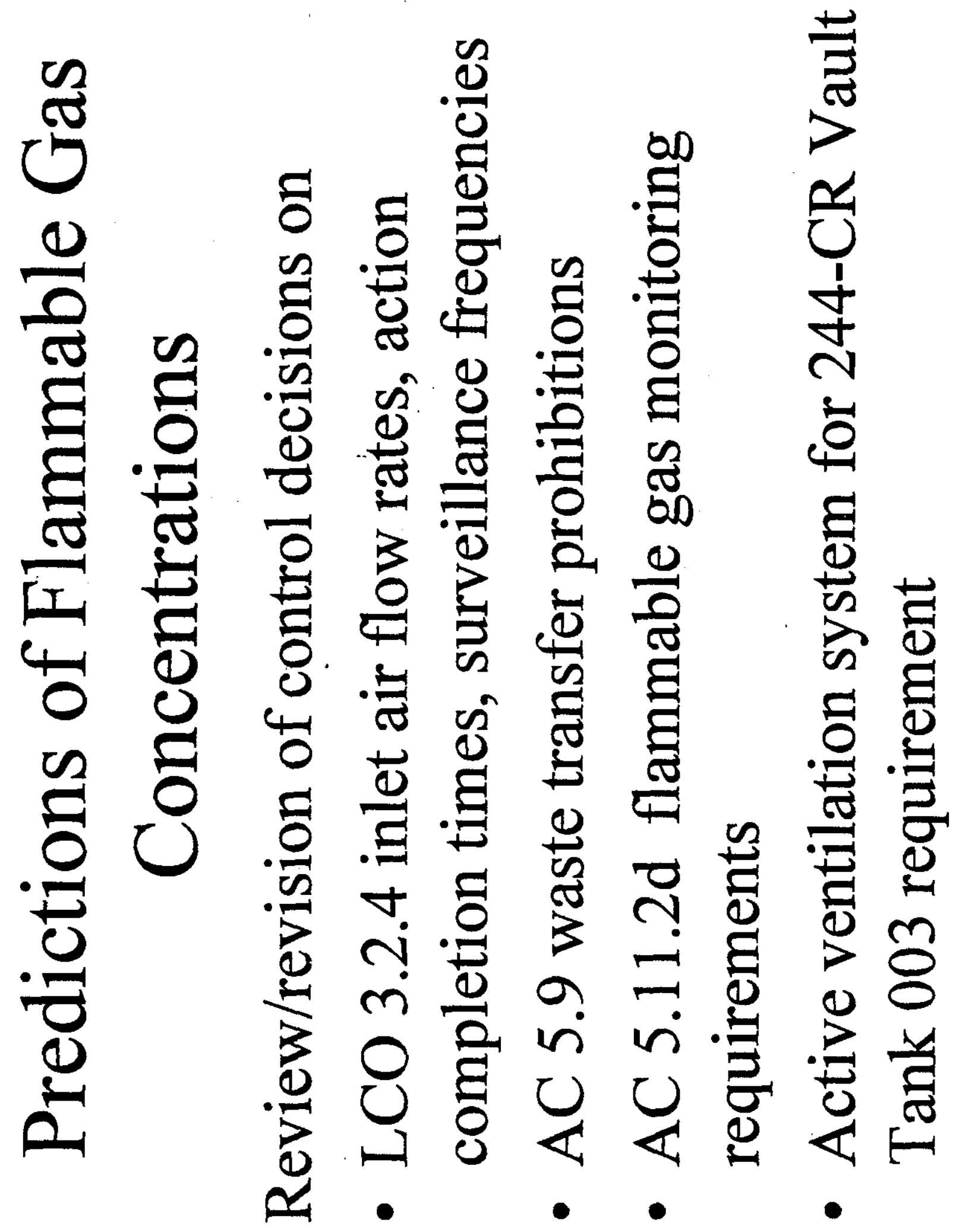


RPP-5554 REV 0

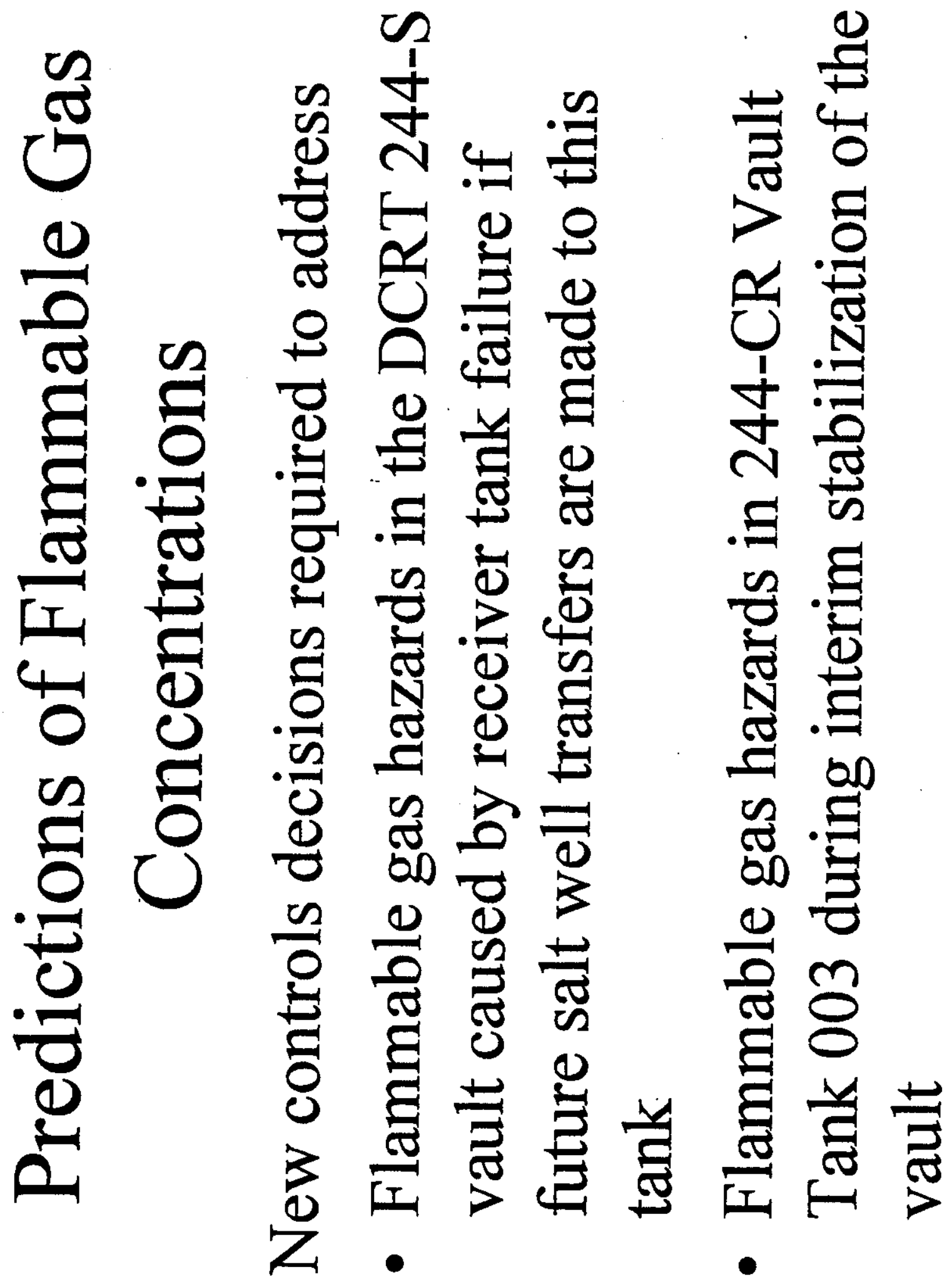


RPP-5554 REV 0

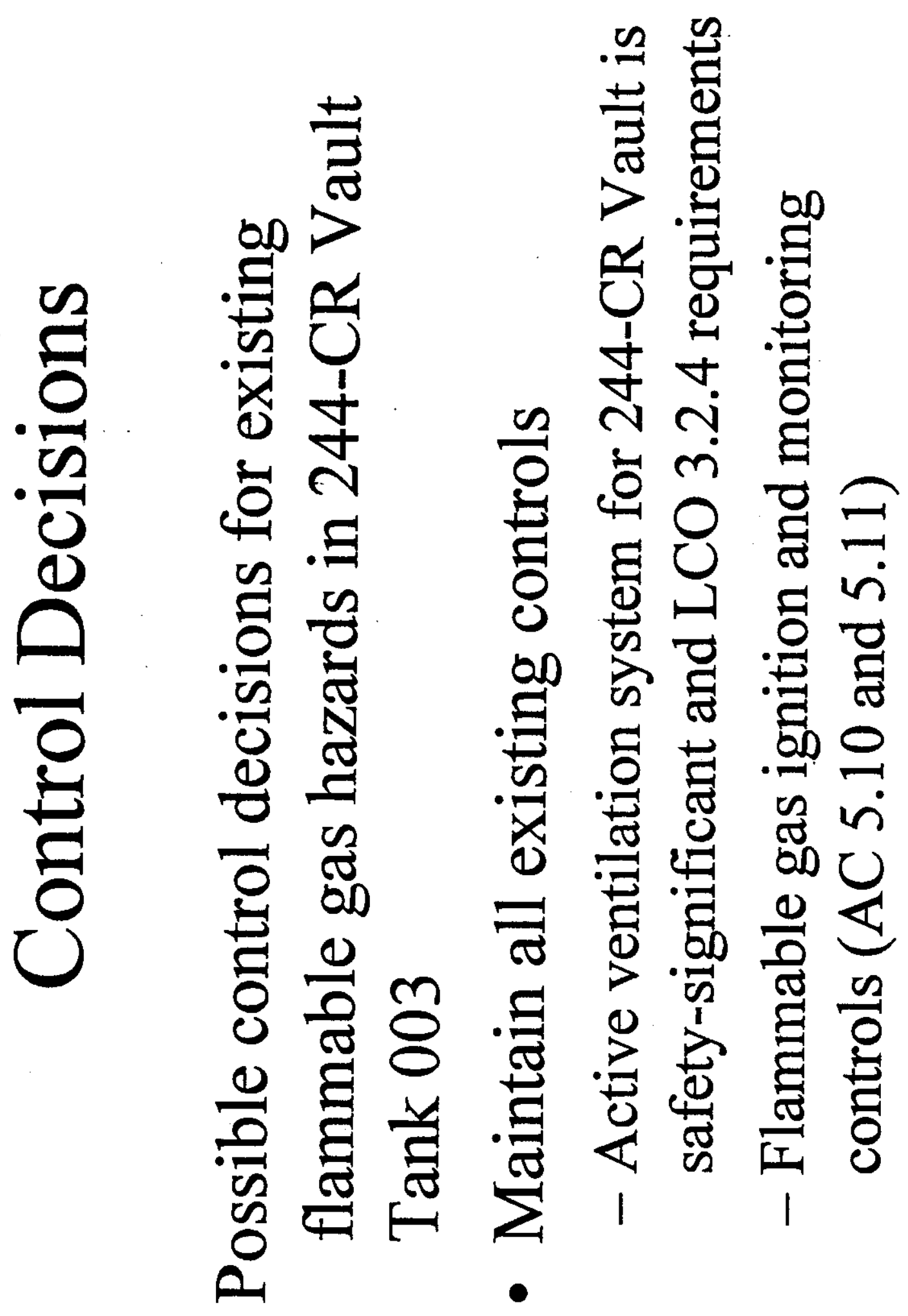



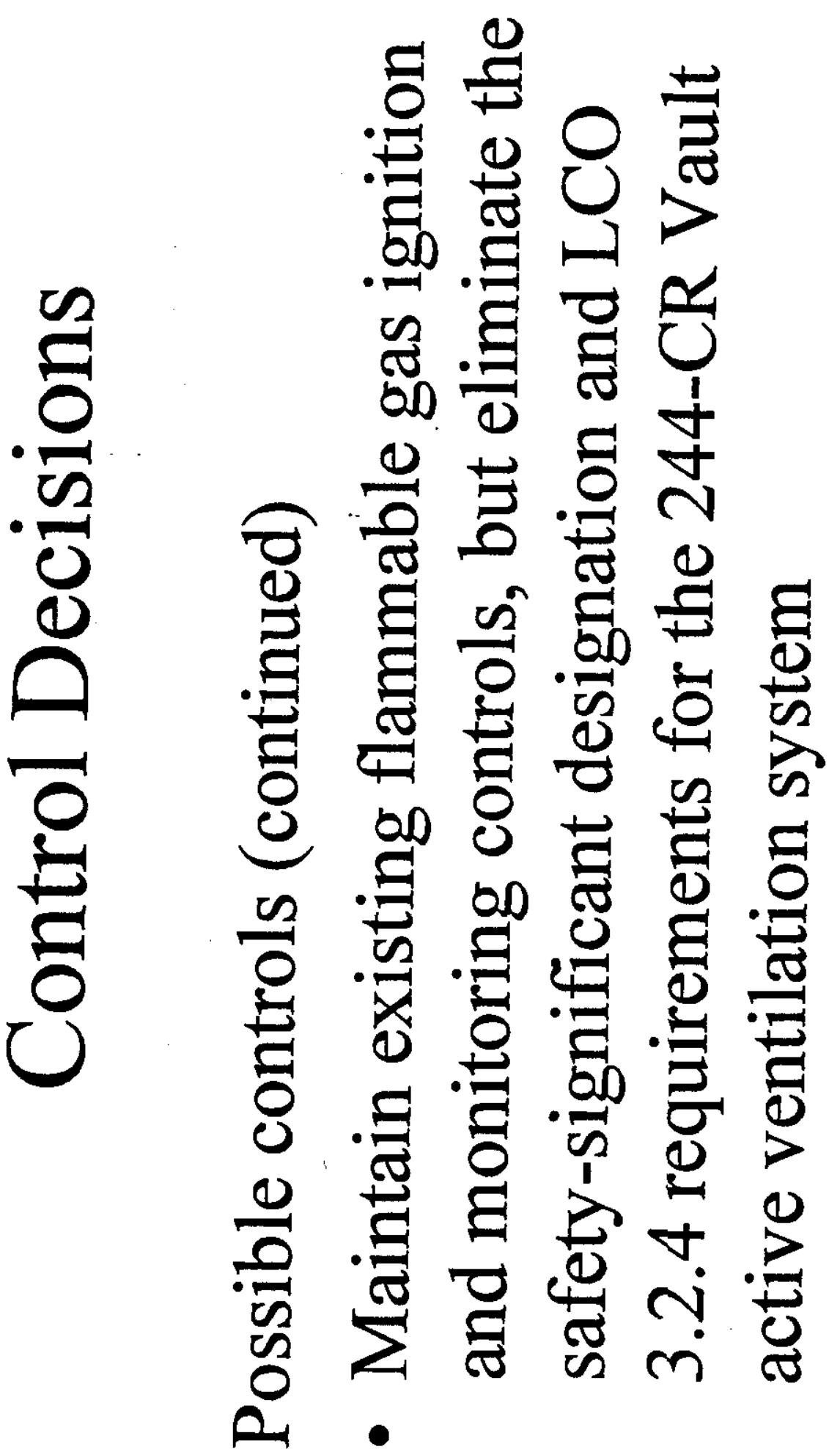

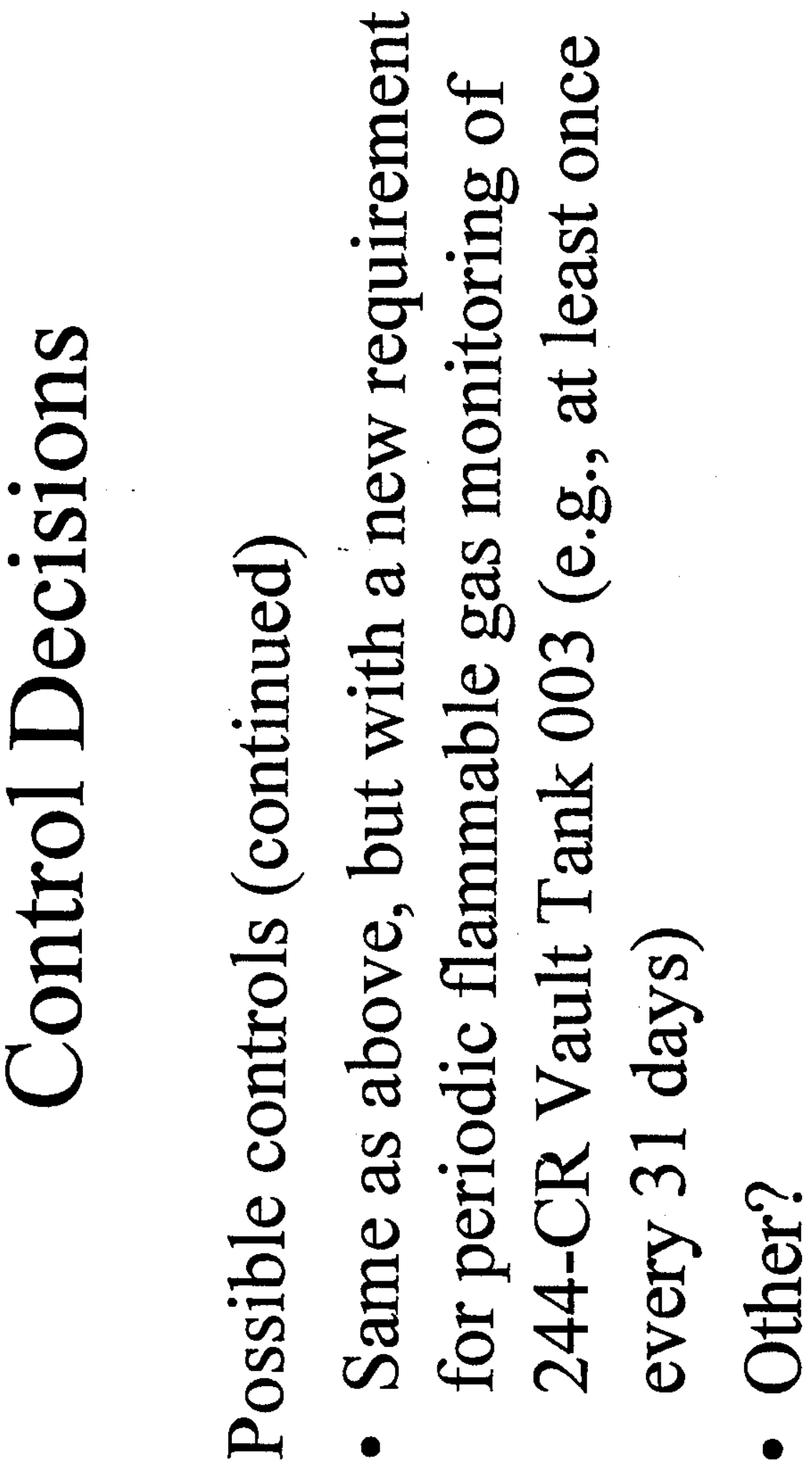


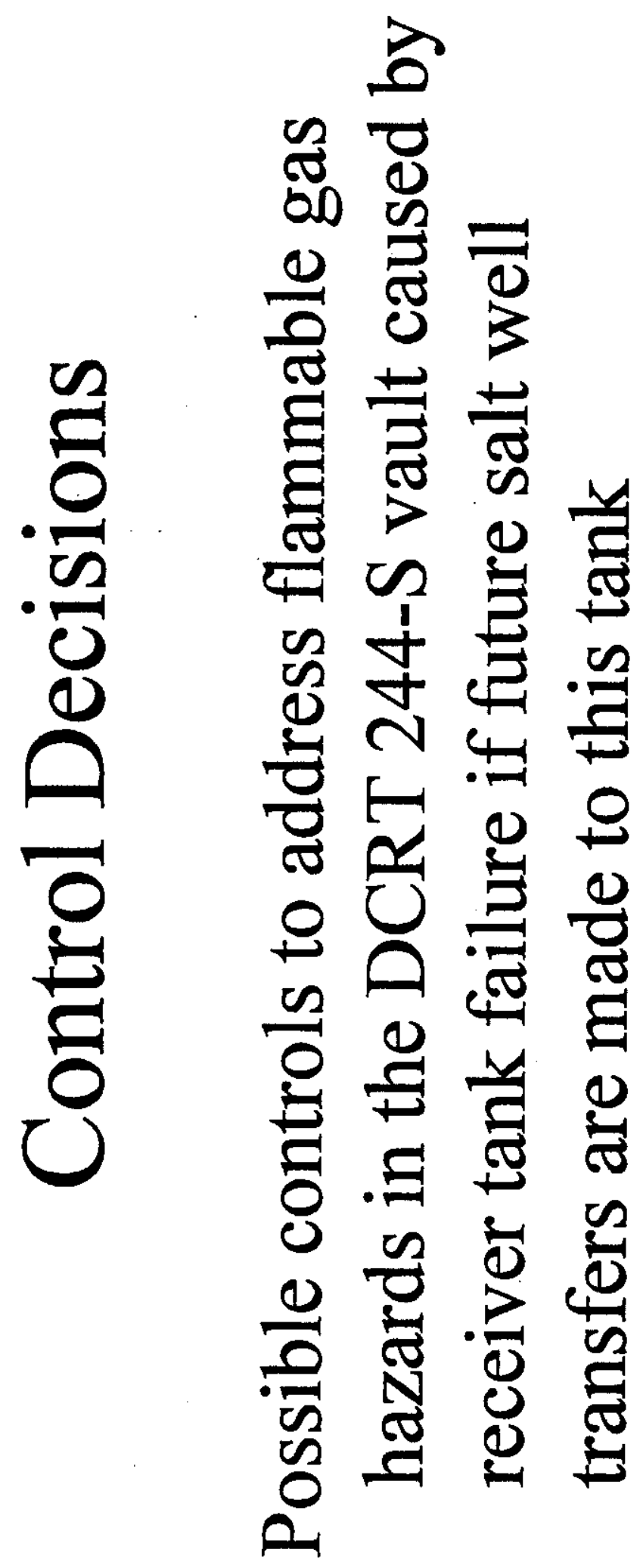

Att 5-27 
RPP-5554 REV 0

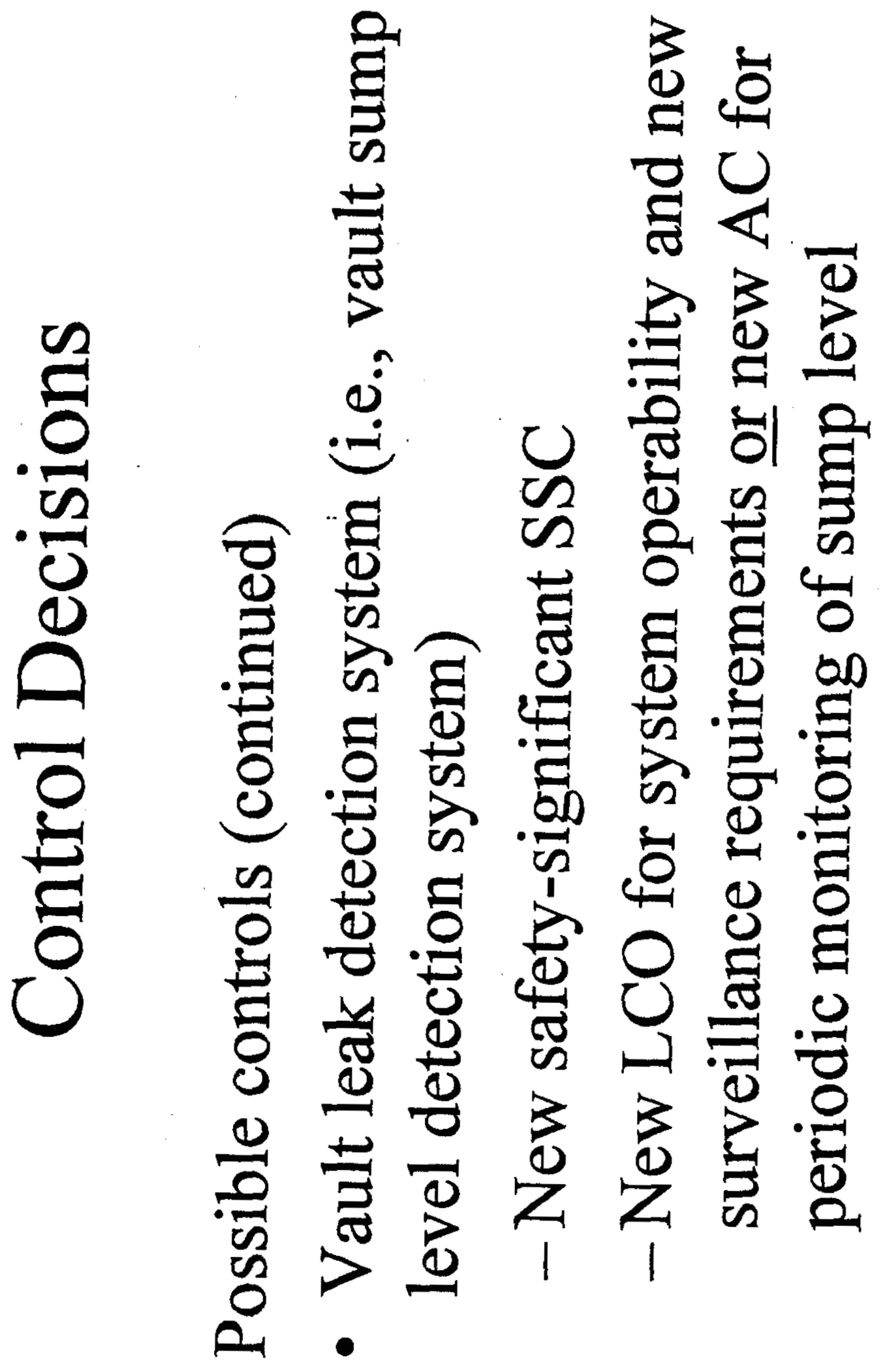


RPP-5554 REV 0
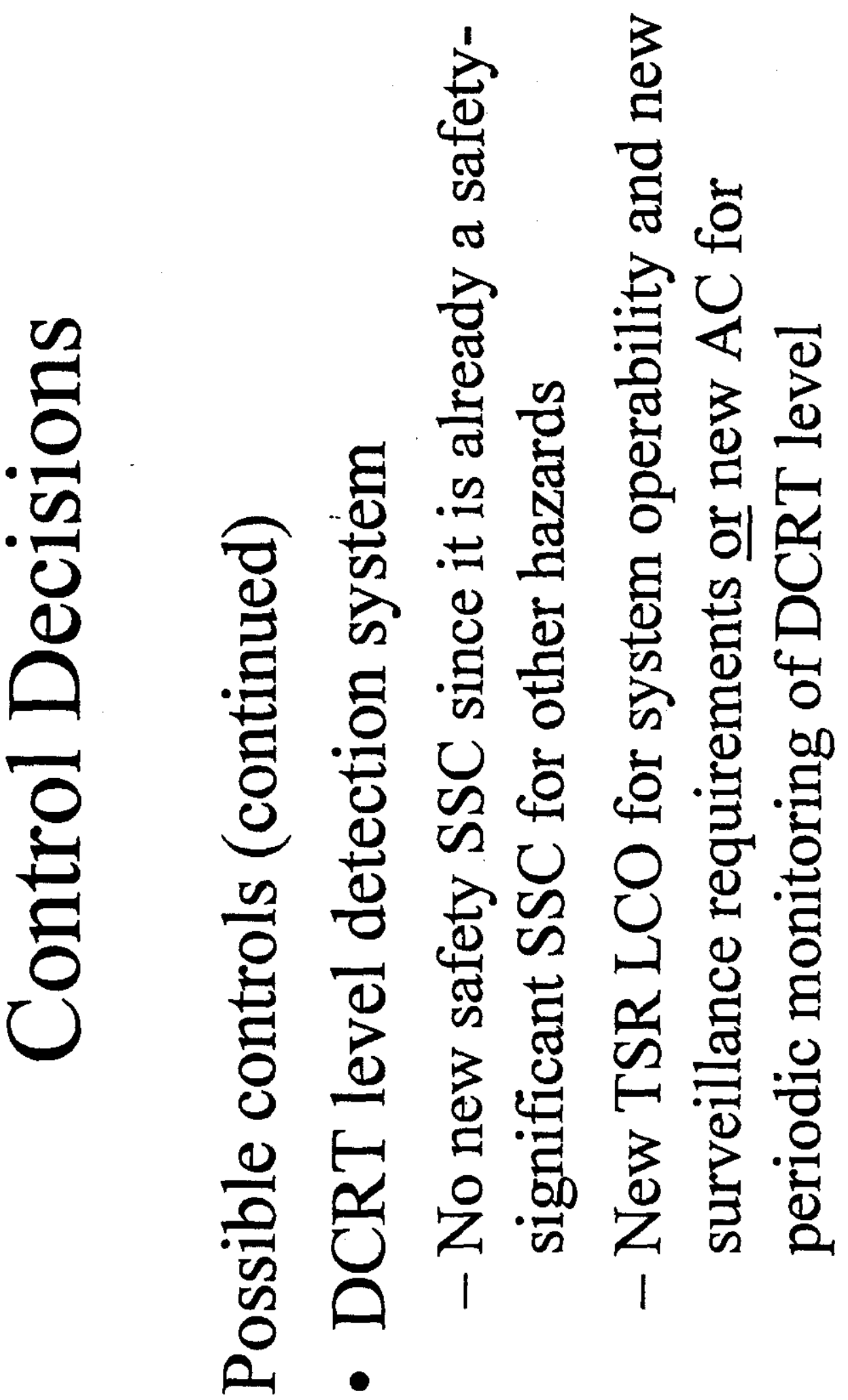
RPP-5554 REV 0

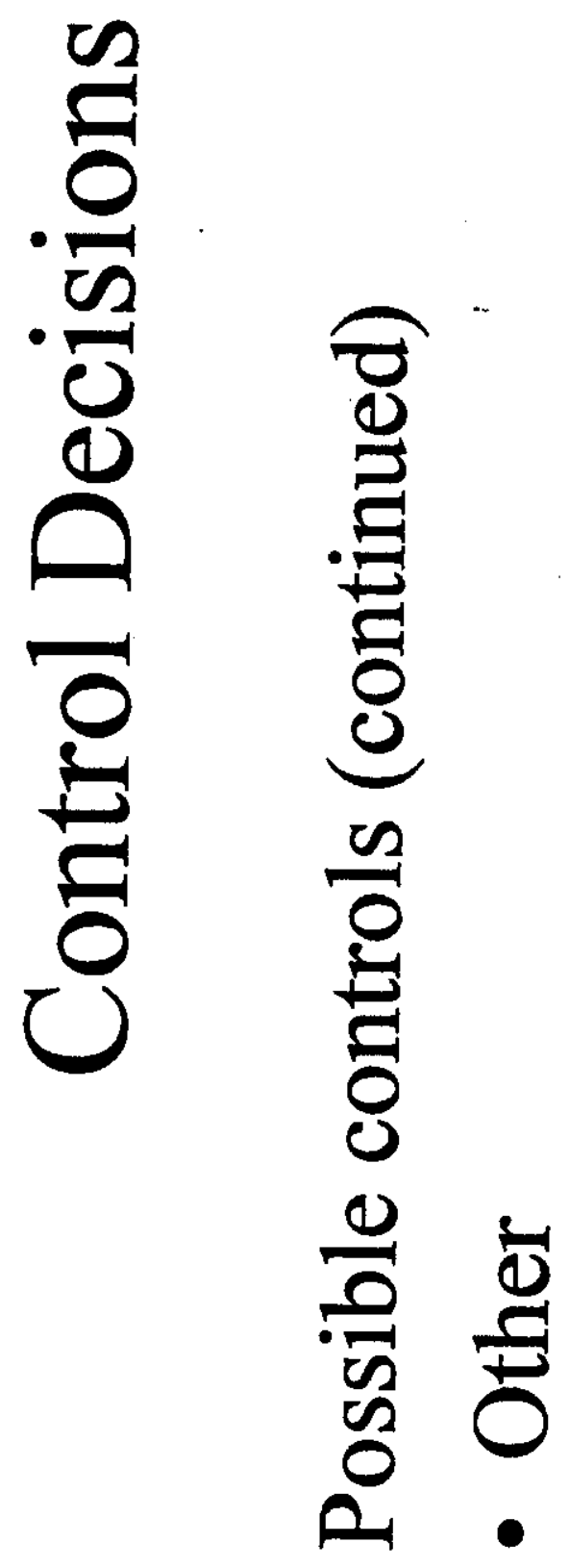

Att 5-30 
RPP-5554 REV 0

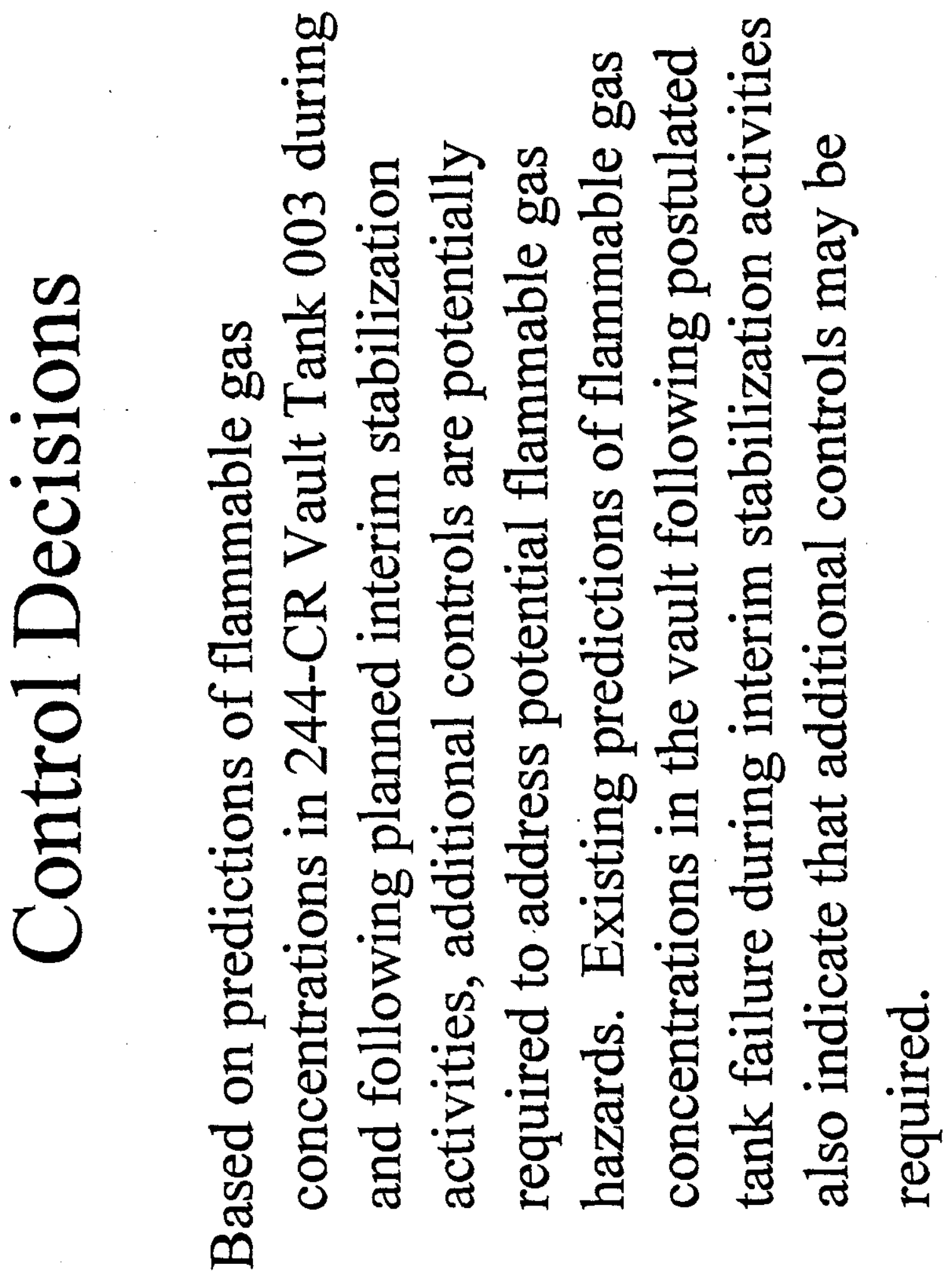


RPP-5554 REV 0

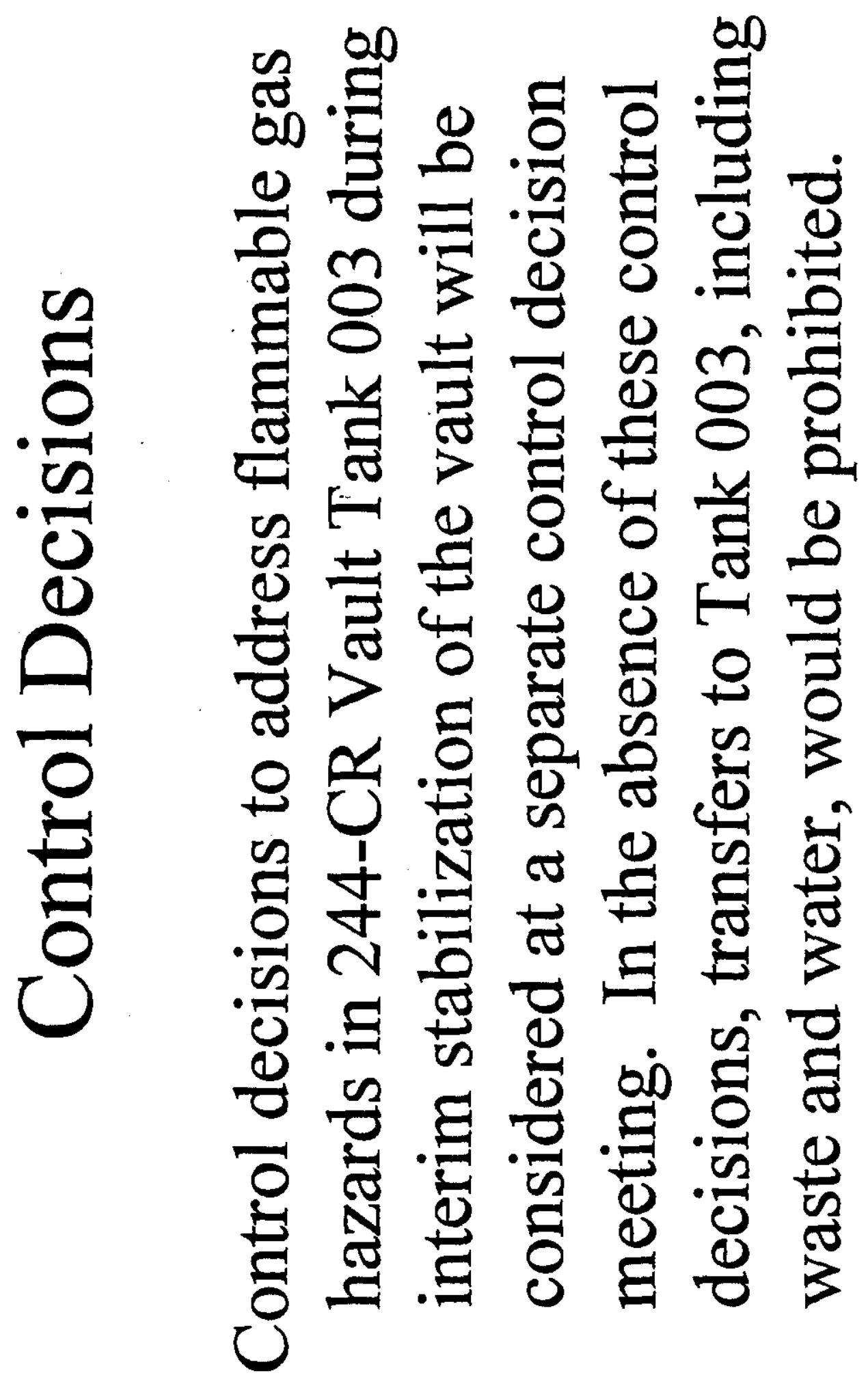


RPP-5554 REV 0

ATTACHMENT 6

CONTROL DECISION MEETING ON MAY 10, 2000 TO ADDRESS FLAMMABLE GAS HAZARDS IN 244-CR VAULT TANK 003 
RPP-5554 REV 0

This page intentionally left blank.

Att 6-ii 


\section{4-CR FLAMMABLE GAS \\ CONTROL DECISION MEETING \\ Wednesday, May 10, 2000 \\ 1300-1500 \\ 2750HV B225}

The purpose of the meeting is to follow-up on the control decision meeting held April 19, 2000. That meeting addressed several flammable gas issues.

However, because there was still more analyses being done on 244-CR and the interim stabilization project team had not had an opportunity to consider options, it was decided to defer the control decision concerning Tank 003 of 244-CR.

The attachment demonstrates that the head space of the tank will reach flammable gas concentrations during the transfer relatively quickly without controls. Further it points out that the concentrations will reach flammable concentrations even after the pumpable liquids are removed assuming only barometric breathing.

This meeting will determine what types of controls are required before the pumping is started, during the transfer operations, and after the pumpable liquid is removed. This will address both the tank and the cell. A conceptual layout of the ventilation system with verification of flows will be considered.

\section{ATTENDANCE}

\begin{tabular}{|l|c|c|}
\hline NAME (Initials) & ORGANIZATION & PHONE NUMBER \\
\hline Larry Kripps LIJ & Nuclear Safety and Licensing & $376-1061$ \\
\hline Jim Zach & Nuclear Safety and Licensing & $373-0670$ \\
\hline Dave Hedengren \& 1 & Process Engineering & $373-5094$ \\
\hline Dave Parkman & Cognizant Engineer & $373-3462$ \\
\hline Steve Henry Sm & 244-CR Interim Stabilization Project & $373-5241$ \\
\hline Jennifer Stewart 7 & Nuclear Safety and Licensing & $376-5633$ \\
\hline & & \\
\hline & & \\
\hline & & \\
\hline
\end{tabular}


Summary of 244-CR Vault Tank 003 Flammable Gas Calculations Supporting Control Revisions

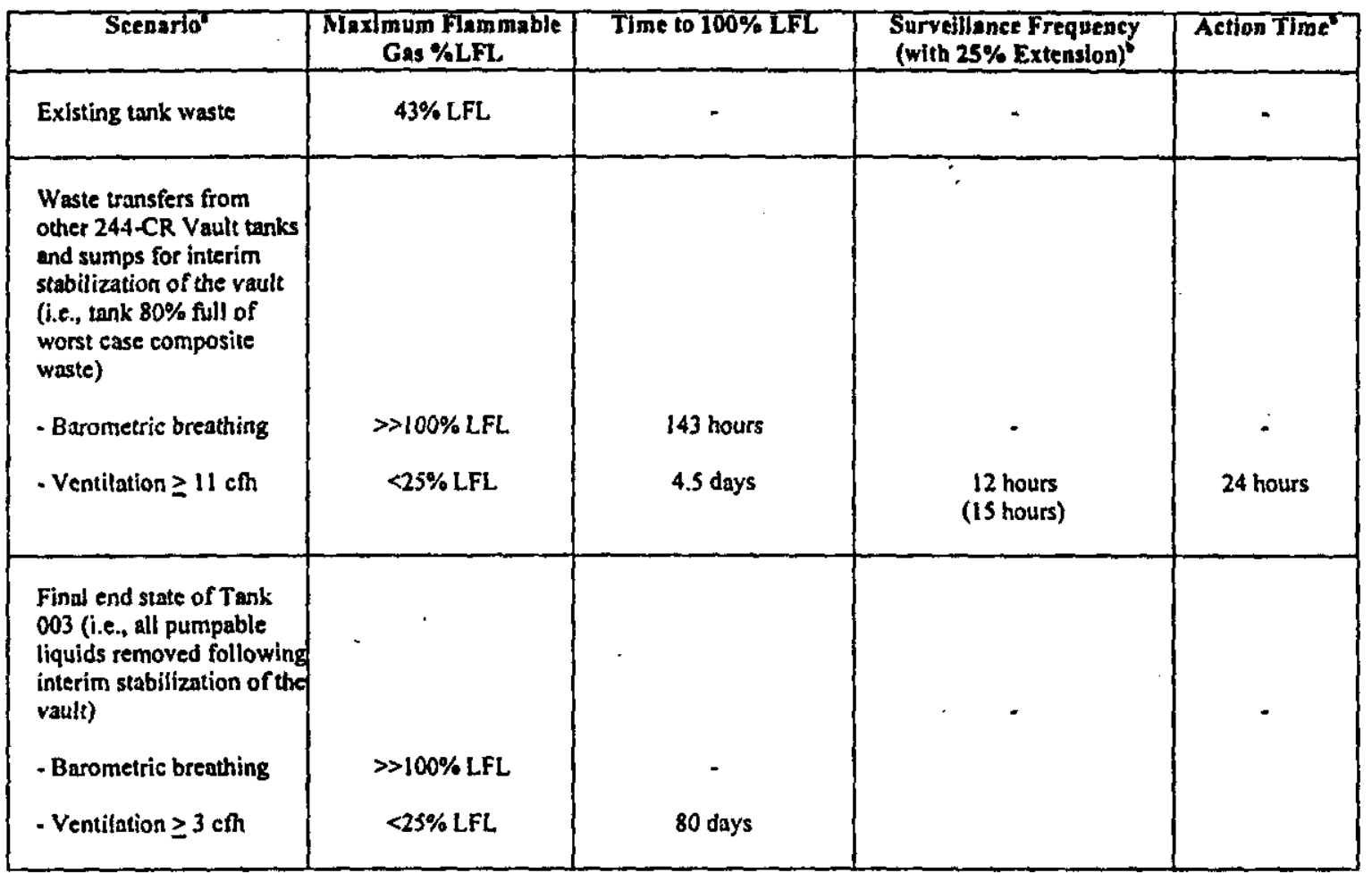

- The only ventilation flow assumed in all scenarios is barometric breathing (i.e., an average air exchange rate of $0.45 \%$ of the DCRT headspace volume per day).

- The surveillance requirement frequency and action completion time must satisfy the following requirement

$[2 \times$ (Surveillance Frequency $+25 \%$ Extension) $]+$ (Action Completion Time) $\leq$ One half of Column 3

The allocation of time between the surveillance requirement frequency and action completion time is a qualitative determined primarily based on operation considerations. 
Summary of DCRT Vault Maximum Flammable Gas Concentrations

The table below summarizes the results of predictions of the maximum flammable gas concentration in a DCRT vault following the postulated failure of the DCRT receiver tank. The DCRT is assume to be $80 \%$ full of waste that will result in the highest flammable gas concentration. The only ventilation flow is barometric breathing (i.e., an average air exchange rate of $0.46 \%$ of the DCRT headspace volume per day).

\begin{tabular}{|c|c|}
\hline DCRT Vault & $\begin{array}{c}\text { Maximum Flammable Gas } \\
\text { Concentration }\end{array}$ \\
\hline $244-A$ & $57.5 \%$ LFL \\
\hline 244-BX & $27.7 \%$ LFL \\
\hline $\begin{array}{l}\text { 244-S } \\
\text { If no future salt well waste transfers } \\
\text { If future salt well waste transfers }\end{array}$ & $\begin{array}{l}\text { 43.9\% LFL } \\
217.4 \% \mathrm{LFL}^{i}\end{array}$ \\
\hline 244-TX & $32.5 \%$ LFL \\
\hline 244-U & $26.2 \%$ LFL \\
\hline $\begin{array}{l}\text { 244-CR Vault } \\
\text { Tank } 80 \% \text { full of worst case composite } \\
\text { Existing tank waste } \\
\text { Existing tank waste plus } 1000 \text { gal sump } \\
\text { water } \\
\text { Final end state of tank }\end{array}$ & $\begin{array}{c}>100 \% \mathrm{LFL}^{\mathrm{ii}} \\
22 \% \mathrm{LFL} \\
22 \% \mathrm{LFL}^{\mathrm{iii}} \\
>100 \% \mathrm{LFL}^{\mathrm{ii}}\end{array}$ \\
\hline
\end{tabular}

\footnotetext{
The predicted time to reach $100 \%$ of the $\mathrm{LFL}$ is 31 days.

ii The predicted time to reach $100 \%$ of the LFL is 45 days.

ii The predicted time to reach $100 \%$ of the LFL is 504 days.
} 


\section{RPP-5554 REV 0}

This page intentionally left blank.

Att 6-4 